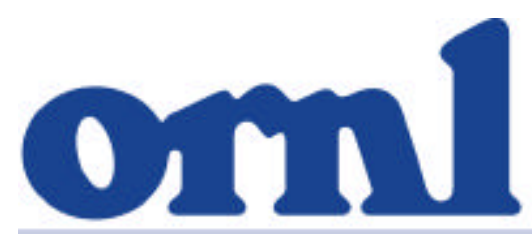

OAK RIDGE NATIONAL LABORATORY

LOCKHEED MATTIN

\title{
Design Studies of "Island" Type MOX Lead Test Assembly
}

A. M. Pavlovitchev

A. A. Alioshin

S. N. Bolshagin

S. A. Bychkov

A. P. Lazarenko

V. D. Sidorenko

Y. A. Styrin

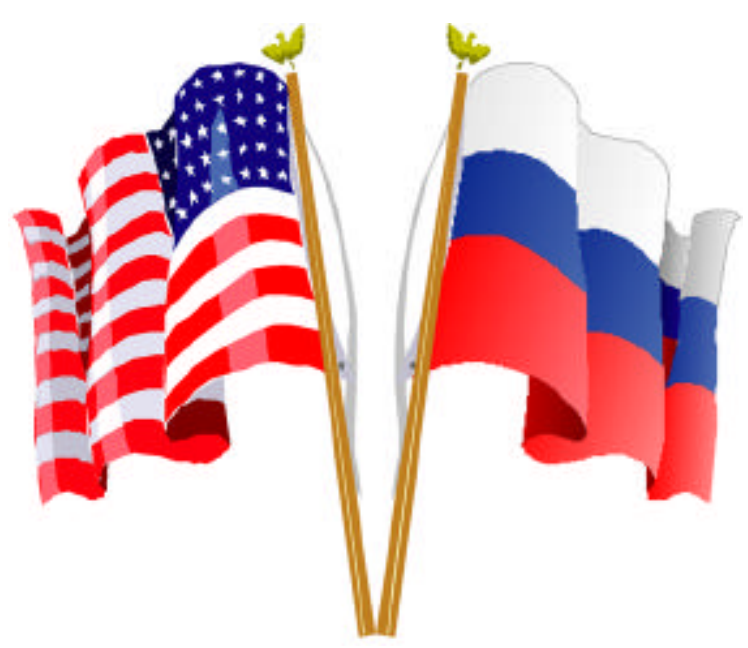

Fissile Materials Disposition Program 
Available electronically from the following source:

Web site www.doe.gov/bridge

Reports are available in paper to the public from the following source.

\author{
U.S. Department of Commerce \\ National Technical Information Service \\ 5285 Port Royal Road \\ Springfield, VA 22161 \\ Telephone 1-800-553-6847 \\ TDD 703-487-4639 \\ Fax 703-605-6900 \\ E-mail orders@ntis.fedworld.gov \\ Web site www.ntis.gov/ordering.htm
}

Reports are available in paper to U.S. Department of Energy (DOE) employees, DOE contractors, Energy Technology Data Exchange (ETDE) representatives, and International Nuclear Information System (INIS) representatives from the following source.

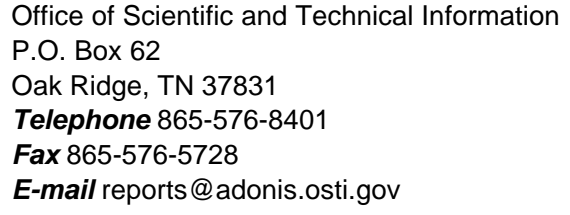

This report was prepared as an account of work sponsored by an agency of the United States Government. Neither the United States Government nor any agency thereof, nor any of their employees, makes any warranty, express or implied, or assumes any legal liability or responsibility for the accuracy, completeness, or usefulness of any information, apparatus, product, or process disclosed, or represents that its use would not infringe privately owned rights. Reference herein to any specific commercial product, process, or service by trade name, trademark, manufacturer, or otherwise, does not necessarily constitute or imply its endorsement, recommendation, or favoring by the United States Government or any agency thereof. The views and opinions of authors expressed herein do not necessarily state or reflect those of the United States Government or any agency thereof. 
ORNL/SUB/99-B99398V-3

\title{
DESIGN STUDIES OF "ISLAND" TYPE MOX LEAD TEST ASSEMBLY
}

\author{
A. M. Pavlovitchev \\ B. A. Alioshin \\ S. N. Bolshagin \\ S. A. Bychkov \\ B. P. Lazarenko \\ V. D. Sidorenko \\ Y. A. Styrin \\ Date Published: March 2000 \\ Prepared by \\ Russian Research Center "Kurchatov Institute" \\ Institute of Nuclear Reactors \\ under \\ Subcontract Number 85B99398V \\ Funded by \\ Office of Fissile Materials Disposition \\ U.S. Department of Energy \\ Prepared for \\ Computational Physics and Engineering Division \\ OAK RIDGE NATIONAL LABORATORY \\ Oak Ridge, Tennessee 37831 \\ managed by \\ LOCKHEED MARTIN ENERGY RESEARCH CORP. \\ for the \\ U.S. DEPARTMENT OF ENERGY \\ under contract DE-AC05-96OR22464
}





\title{
Russian Research Center "Kurchatov Institute" \\ Institute of Nuclear Reactors \\ VVER Division
}

Joint U.S. / Russian Project to Update, Verify and Validate Reactor Design/Safety Computer Codes Associated with Weapons-Grade Plutonium Disposition in WVER Reactors

\section{Design Studies of «Island» Type MOX Lead Test Assembly}

\author{
(Final Report for FY99)
}

General Order 85B-99398V. Work Release 02. P. 99-1a

Project Manager

A.M.Pavlovitchev

Executed by

A.A.Alioshin

S.N.Bolshagin

S.A.Bychkov

A.P. Lazarenko

V.D. Sidorenko

Y.A.Styrin

Moscow 1999 
RUSSIAN RESEARCH CENTER KURCHATOV INSTITUTE

Design Studies of "Island" Type MOX Lead Test Assembly (Report for FY99)

\section{ACRONYMS}

\begin{tabular}{|l|l|l|}
\hline Russian & & $\begin{array}{l}\text { American } \\
\text { Equivalent }\end{array}$ \\
\hline AZ & emergency (accident) protection & AP \\
\hline AZ-1 & $\begin{array}{l}\text { state with all the control rods fully inserted except of } \\
\text { one the most effective stuck in upper position }\end{array}$ & AP-1 \\
\hline BOC & Beginning Of fuel Cycle & BOC \\
\hline BPR & Burnable Poison Rod & BPR \\
\hline DNBR & Departure from Nucleate Boiling Ratio & DNBR \\
\hline DTC & Doppler Temperature Coefficient & DTC \\
\hline EFPD & Effective Full Power Day & EFPD \\
\hline EOC & End Of fuel Cycle & EOC \\
\hline FP & Fission Products & FP \\
\hline KI & Kurchatov Institute & KI \\
\hline LTA & Lead Test Assembly & LTA \\
\hline LWR & Light Water Reactor & LWR \\
\hline MCL & Minimum Controllable reactor power Level & MCL \\
\hline MDC & Moderator Density Coefficient & MDC \\
\hline MOX & Mixed Oxide (uranium-plutonium fuel) & MOX \\
\hline MTC & Moderator Temperature Coefficient & MTC \\
\hline NPP & Nuclear Power Plant & NPP \\
\hline OR & Regulatory Body (Control Rod) & CR \\
\hline PWR & Pressurized-Water Reactor & PWR \\
\hline RCT & Repeat Criticality Temperature & RCT \\
\hline SUZ & Reactor Control and Protection System & RPS \\
\hline TVS, FA & Fuel Assembly & FA \\
\hline UOX & Uranium Oxide Fuel & UOX \\
\hline VVER & Russian water-water reactor & VVER \\
\hline
\end{tabular}


RUSSIAN RESEARCH CENTER KURCHATOV INSTITUTE

Design Studies of "Island" Type MOX Lead Test Assembly (Report for FY99)

\section{EXECUTIVE SUMMARY}

In this document the results of neutronics studies of «Island» type MOX LTA design are presented. The characteristics both for infinite MOX grids and for VVER-1000 core with 3 MOX LTAs are calculated. The neutronics parameters of MOX fuelled core have been performed using the Russian $3 \mathrm{D}$ code BIPR-7A and 2D code PERMAK-A with the constants prepared by the cell spectrum code TVS-M. 
RUSSIAN RESEARCH CENTER KURCHATOV INSTITUTE

Design Studies of "Island" Type MOX Lead Test Assembly (Report for FY99)

\section{CONTENTS}

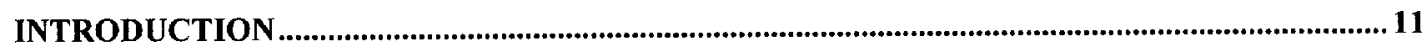

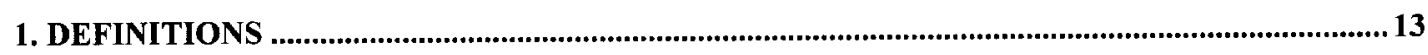

2. PARAMETRIC STUDIES OF MOX LTA DESIGN (STAGE “ASSEMBLY”).................................19

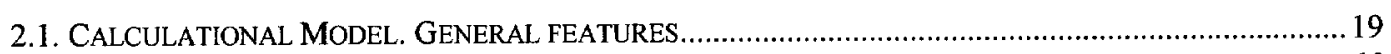

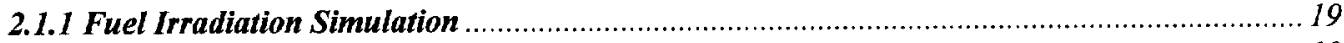

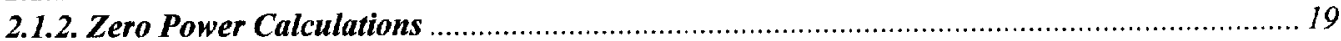

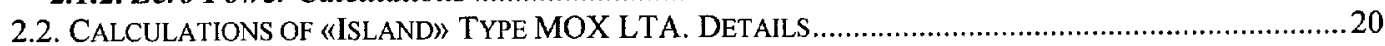

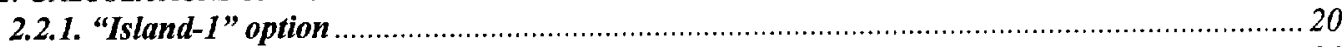

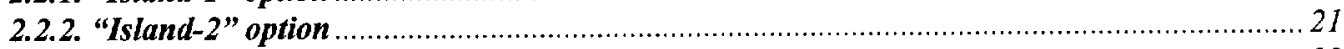

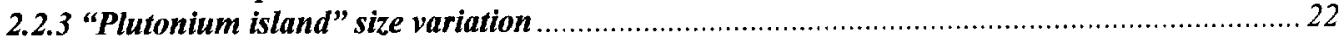

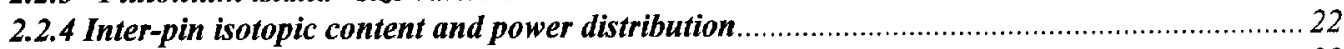

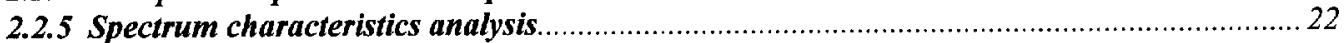

3. CALCULATIONS OF VVER-1000 CORE WITH 3 MOX LTAS (STAGE “CORE") ......................24

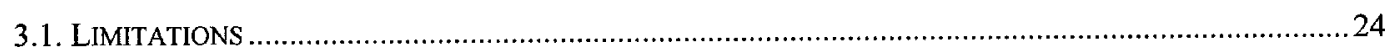

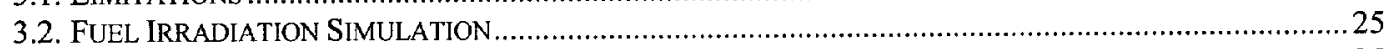

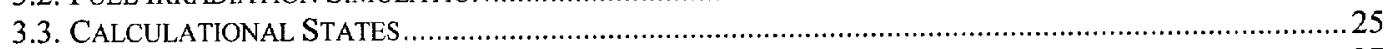

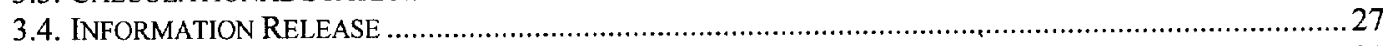

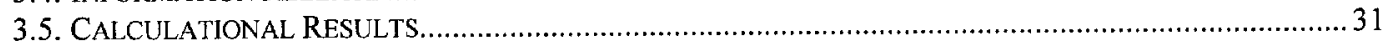

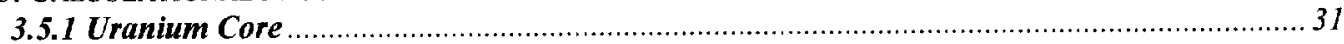

3.5.2. MOX Core ……………

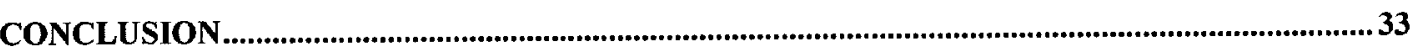

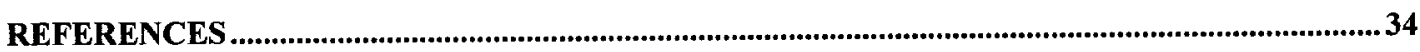

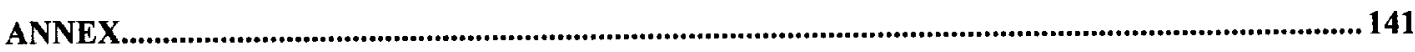

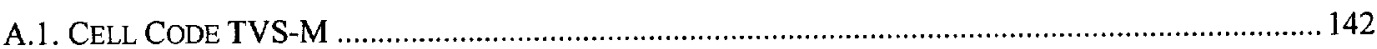

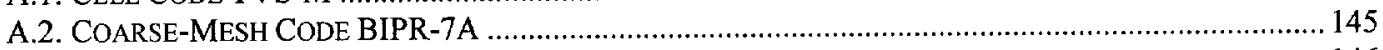

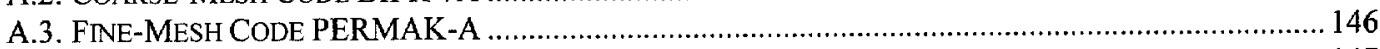

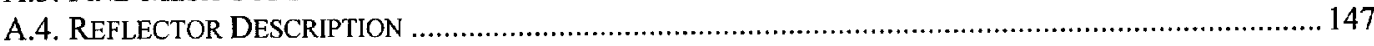

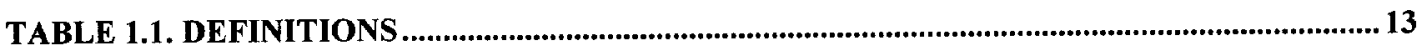

TABLE 2.1. COMPOSITION OF WEAPONS GRADE PLUTONIUM.................................................35

TABLE 2.2. MAIN CORE PARAMETERS ...........................................................................................36

TABLE 2.3. FUEL ASSEMBLY DESIGN PARAMETERS.....................................................................37

TABLE 2.4. URANIUM FUEL PIN DESIGN PARAMETERS ...............................................................38

TABLE 2.5. MOX FUEL PIN DESIGN PARAMETERS ........................................................................39

TABLE 2.6. DISCRETE BURNABLE POISON PIN DESIGN PARAMETERS.................................. 40 
RUSSIAN RESEARCH CENTER KURCHATOV INSTITUTE

Design Studies of "Island" Type MOX Lead Test Assembly (Report for FY99)

TABLE 2.7. KEFF IN ZERO POWER STATES. 41

TABLE 2.8. PARAMETERS EVOLUTION IN THE PROCESS OF FUEL IRRADIATION. REFERENCE URANIUM ASSEMBLAGE. NO BPR .42

TABLE 2.9. PARAMETERS EVOLUTION IN THE PROCESS OF FUEL IRRADIATION. REFERENCE URANIUM ASSEMBLAGE WITH BORON BPRS.

TABLE 2.10. PARAMETERS EVOLUTION IN THE PROCESS OF FUEL IRRADIATION.

"ISLAND-2" TYPE MOX LTA .............................................................................................................44

TABLE 3.1. LIMITING PARAMETERS FOR VVER-1000 ...................................................................45

TABLE 3.2. LIMITS RECOMMENDED FOR TOTAL POWER PEAKING FACTOR KO-TOTAL FOR VVER-1000.

TABLE 3.3. RECOMMENDED LIMITING PARAMETERS FOR VVER-1000 WITH 3 MOX

LTAS. 46

TABLE 3.4. LIMITS RECOMMENDED FOR TOTAL POWER PEAKING FACTOR K $\mathrm{K}_{\text {-TOTAL }}$ IN MOX ASSEMBLIES FOR VVER-1000 WITH 3 MOX LTAS .

TABLE 3.5. EVOLUTION OF MAIN NEUTRONICS PARAMETERS IN URANIUM REFERENCE CORE . EQUILIBRIUM CYCLE 47

TABLE 3.6. MAIN NEUTRONICS PARAMETERS IN ZERO POWER STATES. REFERENCE URANIUM CORE EQUILIBRIUM CYCLE.

TABLE 3.7. EVOLUTION OF MAIN NEUTRONICS PARAMETERS. FIRST CYCLE WITH 3 MOX LTAS OF "ISLAND-2" TYPE

TABLE 3.8. MAIN NEUTRONICS PARAMETERS IN ZERO POWER STATES. FIRST CYCLE WITH 3 MOX LTAS OF "ISLAND-2" TYPE.

TABLE 3.9. EVOLUTION OF MAIN NEUTRONICS PARAMETERS. SECOND CYCLE WITH 3

MOX LTAS OF "ISLAND-2" TYPE ................................................................................................... 51

TABLE 3.10. MAIN NEUTRONICS PARAMETERS IN ZERO POWER STATES. SECOND CYCLE WITH 3 MOX LTAS OF "ISLAND-2" TYPE

TABLE 3.11. EVOLUTION OF MAIN NEUTRONICS PARAMETERS. 3-D CYCLE WITH 3 MOX LTAS OF "ISLAND-2" TYPE

TABLE 3.12. MAIN NEUTRONICS PARAMETERS IN ZERO POWER STATES. THIRD CYCLE

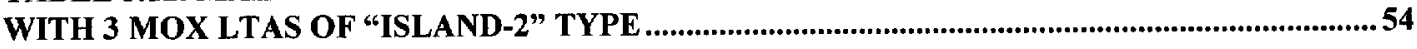

TABLE 3.13. PIN POWER PEAKING FACTORS ATTAINED DURING FUEL CYCLE..................55

TABLE 3.14. CORE SUBCRITICALITY (SCRAM MARGIN) IN DIFFERENT STATES IN THE

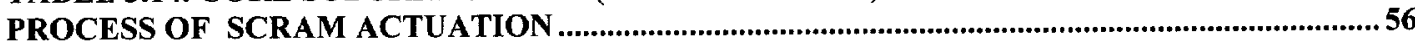

TABLE 3.15A. CONTROL RODS WORTH CALCULATION. STATES DESCRIPTION ................57

TABLE 3.15B. CONTROL RODS WORTH IN URANIUM REFERENCE CORE AND IN 3 MOX LTAS LOADED CORES (PCM) .........................................................................................................5 
RUSSIAN RESEARCH CENTER KURCHATOV INSTITUTE

Design Studies of "Island" Type MOX Lead Test Assembly (Report for FY99)

TABLE 3.16. CORE REACTIVITY IN THE PROCESS OF CONTROL RODS MOVEMENT.......58

TABLE 3.17. RETURN CRITICALITY TEMPERATURE . .59

FIGURE 2.1. SIMPLIFIED DESIGN FOR URANIUM REFERENCE ASSEMBLY (TYPE A) ..........60 FIGURE 2.2. CALCULATIONAL MODEL FOR REFERENCE URANIUM ASSEMBLY SURROUNDED BY URANIUM ASSEMBLIES. 60 $0^{\circ}$ SECTOR. .61

FIGURE 2.3. SIMPLIFIED DESIGN FOR URANIUM ASSEMBLY (TYPES B AND BA) ..................62

FIGURE 2.4. SIMPLIFIED DESIGN FOR URANIUM ASSEMBLY (TYPE C) ..................................63

FIGURE 2.5. SIMPLIFIED DESIGN FOR $100 \%$ PLUTONIUM (3-ZONES) MOX LTA ...................64

FIGURE 2.6. CALCULATIONAL MODEL FOR 3-ZONES (100\% PLUTONIUM) MOX LTA

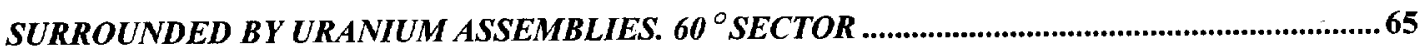

FIGURE 2.7. SIMPLIFIED DESIGN FOR “ISLAND-1” TYPE MOX LTA ........................................66

FIGURE 2.8. CALCULATIONAL MODEL FOR "ISLAND-I" MOX LTA SURROUNDED BY

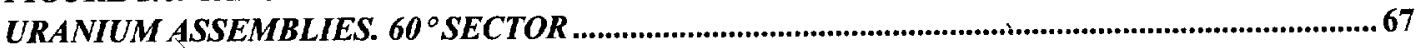

FIGURE 2.9. SIMPLIFIED DESIGN FOR “ISLAND-2" TYPE LTA.................................................68

FIGURE 2.10. CALCULATIONAL MODEL FOR "ISLAND-2" MOX LTA SURROUNDED BY URANIUM ASSEMBLIES. 60 ${ }^{\circ}$ SECTOR ….........................................................................................69

FIGURE 2.11. PINS NUMERATION IN CS MODEL ........................................................................ 70

FIGURE 2. 12. EVOLUTION OF KO IN PLUTONIUM-URANIUM SUPER-CELLS ..........................71

FIGURE 2.13. EVOLUTION OF KK IN URANIUM/PLUTONIUM SUPER-CELLS.............................72

FIGURE 2.14. PARAMETRIC STUDIES OF «ISLAND-2» TYPE MOX LTA (U 3.7\%) .......................73

FIGURE 2.15. PARAMETRIC STUDIES OF «ISLAND-2» TYPE MOX LTA (U 4.4\%) ........................74

FIGURE 2.16. KK VERSUS PERIPHERAL PLUTONIUM ENRICHMENT FOR DIFFERENT BORON CONCENTRATIONS. 3.7\% - URANIUM REGION ENRICHMENT ....................................... 75

FIGURE 2.17. KK VERSUS PERIPHERAL PLUTONIUM ENRICHMENT FOR DIFFERENT BORON CONCENTRATIONS. 4.4\% - URANIUM REGION ENRICHMENT .......................................76

FIGURE 2.18. INTER-ASSEMBLY POWER DISTRIBUTION VERSUS PERIPHERAL PLUTONIUM ENRICHMENTS. 4\% - CENTRAL PLUTONIUM ENRICHMENT. 3.7\% - URANIUM ZONE ENRICHMENT. 77

FIGURE 2.19. INTER-ASSEMBLY POWER DISTRIB UTION VERSUS PERIPHERAL PLUTONIUM ENRICHMENTS. 3\% - CENTRAL PLUTONIUM ENRICHMENT. 3.7\% - URANIUM ZONE ENRICHMENT. .78 
RUSSIAN RESEARCH CENTER KURCHATOV INSTITUTE

Design Studies of "Island" Type MOX Lead Test Assembly (Report for FY99)

FIGURE 2.20. INTER-ASSEMBLY POWER DISTRIBUTION VERSUS PERIPHERAL PLUTONIUM ENRICHMENTS. 4\% - CENTRAL PLUTONIUM ENRICHMENT. 4.4\% - URANIUM ZONE ENRICHMENT.

FIGURE 2.21. INTER-ASSEMBLY POWER DISTRIBUTION VERSUS PERIPHERAL PLUTONIUM ENRICHMENTS. 3\% - CENTRAL PLUTONIUM ENRICHMENT. 4.4\% - URANIUM ZONE ENRICHMENT.. 80

FIGURE 2.22. COMPARISON OF POWER INTER-ASSEMBLY DISTRIBUTIONS IN "ISLAND-2" OF OPTIMUM GRADING. 3\% PLUTONIUM CENTRAL PART WITH 3.7\% AND 4.4\% URANIUM REGIONS

FIGURE 2.23. COMPARISON OF POWER INTER-ASSEMBLY DISTRIBUTIONS IN “ISLAND-2" OF OPTIMUM GRADING. 4\% PLUTONIUM CENTRAL PART WITH 3.7\% AND 4.4\% URANIUM REGIONS

FIGURE 2.24. COMPARISON OF POWER INTER-ASSEMBLY DISTRIBUTIONS IN “ISLAND-1". 3\% PLUTONIUM CENTRAL PART WITH 3.7\% AND 4.4 URANIUM REGIONS. .83

FIGURE 2.25. COMPARISON OF POWER INTER-ASSEMBLY DISTRIBUTIONS IN "ISLAND-1". $4 \%$ PLUTONIUM CENTRAL PART WITH 3.7\% AND 4.4 URANIUM REGIONS ............................8 84 FIGURE 2. 26. SIMPLIFIED DESIGN FOR "INCREASED ISLAND-2" TYPE MOX LTA ............85 FIGURE 2. 27. KK AGAINST «ISLAND-2» PERIPHERY ENRICHMENT FOR DIFFERENT "ISLAND-2"SIZE. "ISLAND-2" CENTRAL ENRICHMENT-4.0\%, URANIUM ENRICHMENT$3.7 \%$

FIGURE 2. 28. KK AGAINST “ISLAND-2» PERIPHERY ENRICHMENT FOR DIFFERENT "ISLAND-2» SIZE. «ISLAND-2» CENTRAL ENRICHMENT-4.0\%, URANIUM ENRICHMENT$4.4 \%$

FIGURE 2. 29. INTER-PIN RELATIVE BURNUP DISTRIBUTION..........................................8

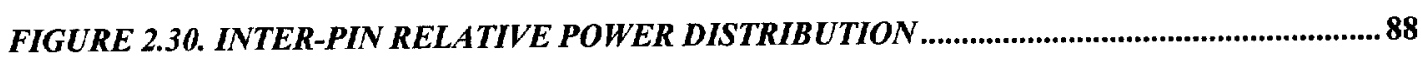

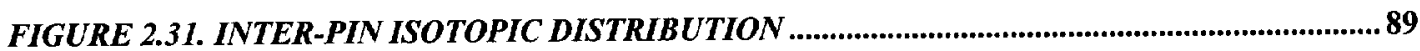

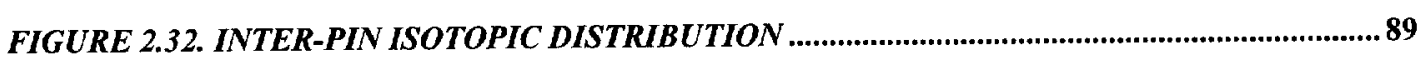

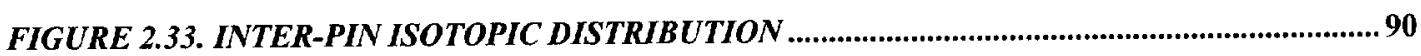

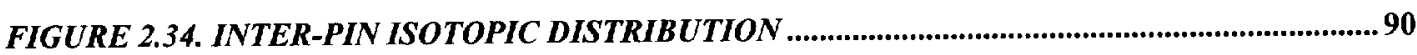

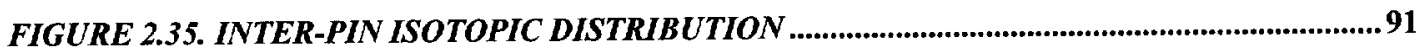

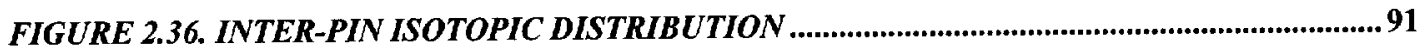

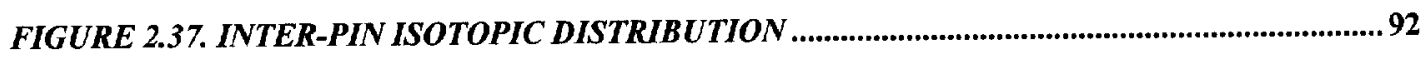

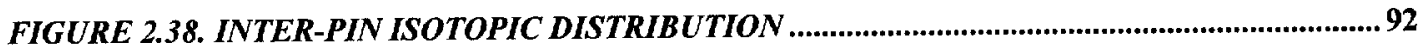

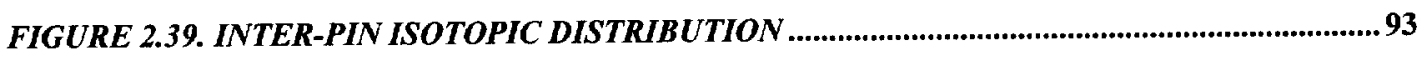

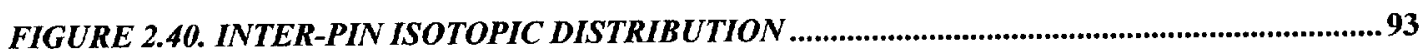


RUSSIAN RESEARCH CENTER KURCHATOV INSTITUTE

Design Studies of "Island" Type MOX Lead Test Assembly (Report for FY99)

FIGURE 2.41. SPECTRUM PARAMETERS DISTRIBUTION IN 100\% PLUTONIUM MOX ASSEMBLY. (PU 3.8. SECTOR 60\%)

FIGURE 2.42. SPECTRUM PARAMETERS DISTRIBUTION IN «ISLAND» TYPE MOX ASSEMBLY

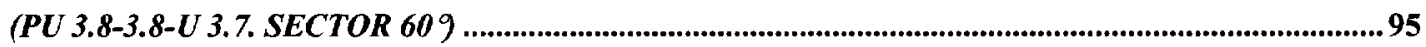

FIGURE 2.43. SPECTRUM PARAMETERS DISTRIBUTION IN "ISLAND) TYPE MOX ASSEMBLY

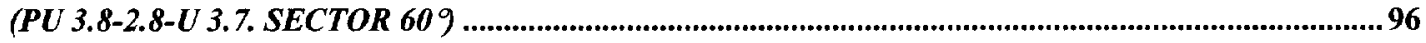

FIGURE 2.44. POWER DISTRIBUTION IN «ISLAND-2》 TYPE MOX ASSEMBLY (PU 3.8-2.8-U 3.7.

SECTOR 609

FIGURE 2.45. POWER DISTRIBUTION IN «ISLAND-2» TYPE MOX ASSEMBLY (PU 3.8-2.8-U 3.7. SECTOR 609 .98

FIGURE 2.46. BURNUP DISTRIBUTION IN "ISLAND-2» TYPE MOX ASSEMBLY (PU 3.8-2.8-U 3.7. SECTOR 609

FIGURE 2.47. ASSEMBLY PARAMETERS EVOLUTION FOR DIFFERENT ENRICHMENT COMPOSITIONS

FIGURE 2.48. ASSEMBLY PARAMETERS EVOLUTION FOR DIFFERENT ENRICHMENT COMPOSITIONS. 101

FIGURE 2.49. EVOLUTION OF PIN ISOTOPIC CONTENT. 102

FIGURE 2.50. EVOLUTION OF PIN ISOTOPIC CONTENT. 102

FIGURE 2.51. EVOLUTION OF PIN ISOTOPIC CONTENT 103

FIGURE 2.52. EVOLUTION OF PIN ISOTOPIC CONTENT. 103

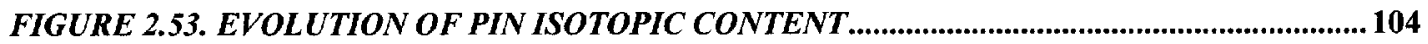

FIGURE 2.54. EVOLUTION OF PIN ISOTOPIC CONTENT.. 104

FIG.3.1. ASSEMBLY-BY-ASSEMBLY BURNUP, POWER AND TEMPERATURE DROPS DISTRIBUTIONS. EQUILIBRIUM CYCLE FOR URANIUM REFERENCE CORE WITH BORON BPRS. CORE $60^{\circ}$ SECTOR. 105

FIG.3.2. ASSEMBLY-BY-ASSEMBLY MAXIMUM LINEAR PIN POWER DISTRIBUTION IN BOC. EQUILIBRIUM CYCLE FOR URANIUM REFERENCE CORE WITH BORON BPRS. CORE 60 SECTOR 106

FIG.3.3. ASSEMBLY-BY-ASSEMBLY MAXIMUM LINEAR PIN POWER DISTRIBUTION IN EOC. EQUILIBRIUM CYCLE FOR URANIUM REFERENCE CORE WITH BORON BPRS.CORE 60 SECTOR. 107

FIG.3.4. PIN-BY-PIN POWER DISTRIBUTION IN THE MOST POWERED ASSEMBLY IN BOC. EQUILIBRIUM CYCLE FOR URANIUM REFERENCE CORE WITH BORON BPRS ................... 108

FIG.3.5. PIN-BY-PIN POWER DISTRIBUTION IN THE MOST POWERED ASSEMBLY IN EOC. EQUILIBRIUM CYCLE FOR URANIUM REFERENCE CORE WITH BORON BPRS. 109 
RUSSIAN RESEARCH CENTER KURCHATOV INSTITUTE

Design Studies of “Island" Type MOX Lead Test Assembly (Report for FY99)

FIG.3.6. CONTROL RODS GROUPING AND POSITIONS OF IN-CORE SELF-POWERED DETECTORS 110

FIG.3.7. RELOADING SCHEME. FIRST CYCLE WITH 3 MOX LTAS 111

FIG.3.8. ASSEMBLY-BY-ASSEMBLY POWER DISTRIBUTION. FIRST CYCLE WITH 3 MOX LTAS OF «ISLAND-2» TYPE (PU3.8-2.8, U-3.7)

FIG.3.9. ASSEMBL Y-B Y-ASSEMBLY BURNUP DISTRIBUTION. FIRST CYCLE WITH 3 MOX LTAS OF «ISLAND-2» TYPE (PU3.8-2.8, U-3.7)

FIG.3.10. ASSEMBLY-BY-ASSEMBLY TEMPERATURE DROP DISTRIBUTION. FIRST CYCLE WITH 3 MOX LTAS OF «ISLAND-2》 TYPE (PU3.8-2.8, U-3.7)

FIG.3.11. ASSEMBLY-BY-ASSEMBLY MAXIMUM LINEAR POWER DISTRIBUTION IN BOC. FIRST CYCLE WITH 3 MOX LTAS OF «ISLAND-2" TYPE (PU3.8-2.8-U3.7)

FIG.3.12. ASSEMBLY-BY-ASSEMBLY MAXIMUM LINEAR POWER DISTRIBUTION IN EOC. FIRST CYCLE WITH 3 MOX LTAS 100\%PU (PU3.8-2.8-U3.7) 116

FIG.3.13. PIN-BY-PIN POWER DISTRIBUTION IN THE MOST POWERED ASSEMBLY IN BOC. FIRST CYCLE WITH 3 MOX LTAS OF «ISLAND-2» TYPE (PU3.8-2.8, U-3.7) 117

FIG.3.14. PIN-BY-PIN POWER DISTRIBUTION IN THE MOST POWERED ASSEMBLY IN EOC. FIRST CYCLE WITH 3 MOX LTAS OF «ISLAND-2» TYPE (PU3.8-2.8, U-3.7) 118

FIG.3.15. PIN-BY-PIN POWER DISTRIBUTION IN MOX LTA IN BOC. FIRST CYCLE WITH 3 MOX LTAS OF «ISLAND-2» TYPE (PU3.8-2.8, U-3.7)

FIG.3.16. PIN-BY-PIN POWER DISTRIBUTION IN MOX LTA IN EOC. FIRST CYCLE WITH 3 MOX LTAS OF «ISLAND-2» TYPE (PU3.8-2.8, U-3.7)

FIG.3.17. RELOADING SCHEME. SECOND CYCLE WITH 3 MOX LTAS . 121

FIG.3.18. ASSEMBLY-BY-ASSEMBLY POWER DISTRIBUTION. SECOND CYCLE WITH 3 MOX LTAS OF «ISLAND-2» TYPE (PU3.8-2.8-U3.7) 122

FIG.3.19. ASSEMBLY-BY-ASSEMBLY BURNUP DISTRIBUTION. SECOND CYCLE WITH 3 MOX LTAS OF «ISLAND-2» TYPE (PU3.8-2.8-U3.7) 123

FIG.3.20. ASSEMBLY-BY-ASSEMBLY TEMPERATURE DROP DISTRIBUTION. SECOND CYCLE WITH 3 MOX LTAS OF «ISLAND-2» TYPE (PU3.8-2.8-U3.7). 124

FIG.3.21. ASSEMBLY-BY-ASSEMBLY MAXIMUM LINEAR PIN POWER DISTRIBUTION IN BOC. SECOND CYCLE WITH 3 MOX LTAS OF «ISLAND-2» TYPE (PU3.8-2.8-U3.7) .125

FIG.3.22. ASSEMBLY-BY-ASSEMBLY MAXIMUM LINEAR PIN POWER DISTRIBUTION IN EOC. SECOND CYCLE WITH 3 MOX LTAS OF «ISLAND-2》 TYPE (PU3.8-2.8-U3.7) 126

FIG.3.23. PIN-BY-PIN POWER DISTRIBUTION IN THE MOST POWERED ASSEMBLY IN BOC. SECOND CYCLE WITH 3 MOX LTAS OF «ISLAND-2》 TYPE (PU3.8-2.8-U3.7). 127

FIG.3.24. PIN-BY-PIN POWER DISTRIBUTION IN THE MOST POWERED ASSEMBLY IN EOC. SECOND CYCLE WITH 3 MOX LTAS OF «ISLAND-2» TYPE (PU3.8-2.8-U3.7), 128 
RUSSIAN RESEARCH CENTER KURCHATOV INSTITUTE

Design Studies of "Island" Type MOX Lead Test Assembly (Report for FY99)

FIG.3.25. PIN-BY-PIN POWER DISTRIBUTION IN MOX LTA IN BOC. SECOND CYCLE WITH 3 MOX LTAS OF «ISLAND-2》 TYPE (PU3.8-2.8-U3.7) 129

FIG.3.26. PIN-BY-PIN POWER DISTRIBUTION IN MOX LTA IN EOC. SECOND CYCLE WITH 3 MOX LTAS OF «ISLAND-2»TYPE (PU3.8-2.8-U3.7) 130

FIG.3.27. RELOADING SCHEME. THIRD CYCLE WITH 3 MOX LTAS 131

FIG.3.28. ASSEMBLY-BY-ASSEMBLY POWER DISTRIBUTION. THIRD CYCLE WITH 3 MOX LTAS OF "ISLAND-2" TYPE (PU3.8-2.8-U3.7)

FIG.3.29. ASSEMBLY-BY-ASSEMBLY BURNUP DISTRIBUTION. THIRD CYCLE WITH 3 MOX LTAS OF "ISLAND-2" TYPE (PU3.8-2.8-U3.7)

FIG.3.30. ASSEMBLY-BY-ASSEMBLY TEMPERATURE DROP DISTRIBUTION. THIRD CYCLE WITH 3 MOX LTAS OF «ISLAND-2) TYPE (PU3.8-2.8-U3.7). 134

FIG.3.31. ASSEMBLY-BY-ASSEMBLY MAXIMUM LINEAR POWER DISTRIBUTION IN BOC. THIRD CYCLE WITH 3 MOX LTAS OF «ISLAND-2» TYPE (PU3.8-2.8-U3.7) 135

FIG.3.32. ASSEMBLY-BY-ASSEMBLY MAXIMUM LINEAR POWER DISTRIBUTION IN EOC. THIRD CYCLE WITH 3 MOX LTAS OF «ISLAND-2) TYPE (PU3.8-2.8-U3.7) 136

FIG.3.33. PIN-B Y-PIN POWER DISTRIBUTION IN THE MOST POWERED ASSEMBLY IN BOC. THIRD CYCLE WITH 3 MOX LTAS OF «ISLAND-2» TYPE ( PU3.8-2.8-U3.7)

FIG.3.34. PIN-BY-PIN POWER DISTRIBUTION IN THE MOST POWERED ASSEMBLY IN EOC. THIRD CYCLE WITH 3 MOX LTAS OF «ISLAND-2》 TYPE (PU3.8-2.8-U3.7)

FIG.3.35. PIN-B Y-PIN POWER DISTRIBUTION IN MOX LTA IN BOC. THIRD CYCLE WITH 3 MOX LTAS OF «ISLAND-2, TYPE ( PU3.8-2.8-U3.7)

FIG.3.36. PIN-BY-PIN POWER DISTRIBUTION IN MOX LTA IN EOC. THIRD CYCLE WITH 3 MOX LTAS OF «ISLAND-2» TYPE (PU3.8-2.8-U3.7).

FIGURE A.1. EQUILIBRIUM LOADING PATTERN FOR BASE URANIUM CORE WITH BORON BPRS, CORE $60^{\circ}$ SECTOR. 148

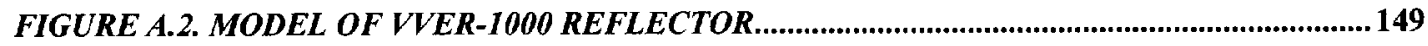

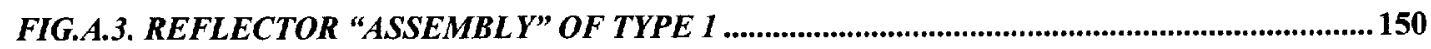

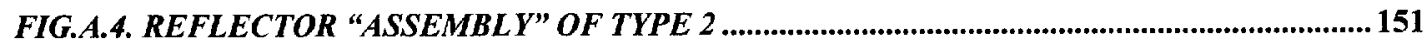

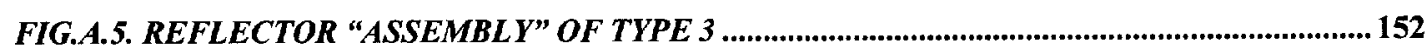

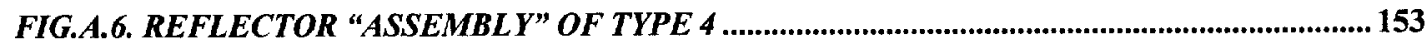

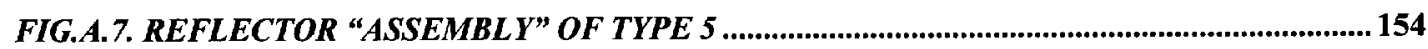




\section{INTRODUCTION}

This work is a part of Joint U.S. / Russian Project with Weapons-Grade Plutonium Disposition in VVER Reactor and presents the results of studies of MOX LTA design of «Island» type.

Two options of «Island» are considered:

- "Island-2" with two regions of different plutonium enrichment, Fig.2.9 (the main case);

- “Island-1" with homogeneous plutonium region, Fig.2.7.

The "Island" type of MOX assembly should be studied additionally to the worldwide full scale (100\% Plutonium, Fig.2.5) MOX assembly because it possesses the following advantages in comparison with $100 \%$ MOX assembly:

- two types of plutonium fuel pins instead of three,

- only uranium fuel pins, whose properties are well studied, are placed near water gap, absent,

- low enrichment plutonium pins, not effective for plutonium burnout, are

- external uranium row can be regarded as a sort of shielding for MOX assembly. It should be taken into account that no additional transport expenses will be incurred if MOX assemblies and uranium assemblies fabrication are not separated.

Besides the Plutonium region in the proposed "Island" configuration possesses the neutron spectrum close to the one in $100 \%$ Plutonium MOX LTA. It can be concluded that if MOX fuel pin fabrication for pilot irradiation in VVER-1000 is limited for any reason, "Island" type MOX LTAs can be used with the same "scientific efficiency" as $100 \%$ PU MOX LTAs.

The presented studies include the ones defined in [2] as the stages "Assembly" and "Core". This report completes the studies partially executed in [3] and [6] and can be considered as a one compiled the previous studies of «Island» MOX LTAs and VVER-1000 core configurations with 3 MOX LTAs .

At the stage "Assembly" in the process of parametric studies two options of infinite grid are considered:

- $\quad$ grid consisting of single MOX LTAs;

- grid consisting of multi-assemblies: a central MOX LTA surrounded by typical uranium assemblies.

Parametric studies must be resulted in the following features of MOX LTA design:

- Proximity of power generation in MOX LTA and in some replaced uranium assembly that was used as a base or reference FA (Fig.2.1); 
- MOX LTA zoning that ensures an acceptable power peaking factor in calculational system.

The Russian cell code TVS-M [3] is used as a calculational instrument at the stage "Assembly".

The stage "Core" comprises studies of characteristics of some base Uranium core (Fig.A.1) with 3 MOX LTAs introduced.

The code TVS-M is used here for generation of neutronics constants to be used in:

- coarse-mesh (assembly-by-assembly) core calculations by the Russian code BIPR$7 \mathrm{~A}[7]$;

- fine-mesh (pin-by-pin) calculations by the Russian code PERMAK-A [7]. and 3.

The stages "Assembly" and "Core" are described correspondingly in Chapters 2

In Chapter 2 additionally to [3] the studies on stability of optimal zoning (i.e. with minimal power peaking factor) are described, particularly, influence of boron concentration in coolant.

In Annex the used codes are briefly described and the detailed reflector description is presented. 
RUSSIAN RESEARCH CENTER KURCHATOV INSTITUTE

Design Studies of "Island" Type MOX Lead Test Assembly (Report for FY99)

\section{Definitions}

Table 1.1. Definitions

\begin{tabular}{|c|c|c|c|}
\hline Parameter & Abbreviation & Units & Remarks \\
\hline Calculational system & $\mathrm{CS}$ & & $\begin{array}{c}\text { Infinite grid of multi-assemblies/single } \\
\text { assemblies or core }\end{array}$ \\
\hline CS symmetry sector & $\operatorname{Sim}$ & & $\begin{array}{l}30 \text { for } 30^{\circ} \\
60 \text { for } 60^{\circ} \\
120 \text { for } 120^{\circ} \\
360 \text { for full CS. }\end{array}$ \\
\hline Reactivity of CS & RO & $\mathrm{pcm}$ & $\mathrm{RO}=($ Keff-1 $) / \mathrm{Keff} * 1 . \mathrm{E} 5$ \\
\hline Calculational volume & $\mathrm{Vij}$ & & $\begin{array}{l}\text { Axial fraction } \mathrm{j} \text { of assembly number } \mathrm{i} \text {. } \\
\text { In VVER-1000 calculations, } 10-30 \text { axial } \\
\text { fractions of equal volume are usually used. }\end{array}$ \\
\hline Effective multiplication factor of CS & Keff & & \\
\hline Multiplication factor of CS & Ko & & $\begin{array}{l}\text { Relation of neutron generation to neutron } \\
\text { absorption. } \\
\text { For core calculations Ko values are attributed } \\
\text { to Vij }\end{array}$ \\
\hline 3-D power distribution in core & $q_{i j}$ & & Power in Vij normalised by average Vij power \\
\hline Volume power peaking factor & $\mathrm{Kv}$ & & Maximum in $\mathrm{q}_{\mathrm{ij}}$ values \\
\hline $\begin{array}{l}\text { Radial position of volume power peaking } \\
\text { factor }\end{array}$ & $\mathrm{N}(\mathrm{Kv})$ or $\mathrm{N}_{\mathrm{K}}$ & & $\begin{array}{l}\text { Number of assembly in calculational core } \\
\text { sector where } \mathrm{Kv} \text { is realised }\end{array}$ \\
\hline $\begin{array}{l}\text { Axial position of volume power peaking } \\
\text { factor }\end{array}$ & $\mathrm{M}(\mathrm{Kv})$ or $\mathrm{N}_{\mathrm{Z}}$ & & Number of axial level where $\mathrm{Kv}$ is realised \\
\hline 3-D burnup distribution in core & BUij & $\mathrm{MWd} / \mathrm{kg}$ & Burnup in Vij. \\
\hline
\end{tabular}


RUSSIAN RESEARCH CENTER KURCHATOV INSTITUTE

Design Studies of "Island" Type MOX Lead Test Assembly (Report for FY99)

\begin{tabular}{|c|c|c|c|}
\hline & & or $\mathrm{GWd} / \mathrm{t}$ & \\
\hline 2-D power distribution in core & $\mathrm{q}_{\mathrm{i}}$ & & $\begin{array}{l}\text { Assembly powers normalised by average } \\
\text { assembly power in core. }\end{array}$ \\
\hline Radial power peaking factor & $\mathrm{Kq}$ & & Maximum in qi values \\
\hline $\begin{array}{l}\text { Radial position of radial power peaking } \\
\text { factor }\end{array}$ & $\mathrm{N}(\mathrm{Kq})$ or $\mathrm{N}_{\mathrm{K}}$ & & $\begin{array}{l}\text { Number of assembly in calculational core } \\
\text { sector where } \mathrm{Kq} \text { is realised }\end{array}$ \\
\hline Pin linear power & Q1 & $\mathrm{W} / \mathrm{cm}$ & $\begin{array}{l}\text { Pin power for } 1 \mathrm{~cm} \text { of an axial calculational } \\
\text { fraction }\end{array}$ \\
\hline Moment during fuel irradiation & $\mathrm{T}$ & EFPD & \\
\hline 2-D burnup distribution in core & $\mathrm{BUi}$ & $\mathrm{MWd} / \mathrm{kg}$ & Average-assembly burnup distribution in core. \\
\hline Average burnup in Uranium assemblies & $\overline{\mathrm{B}}_{U}$ & $\begin{array}{l}\mathrm{MWd} / \mathrm{kg} \\
\text { or GWd/t }\end{array}$ & \\
\hline Average burnup in MOX assemblies & $\overline{\mathrm{B}}_{\mathrm{MOX}}$ & $\begin{array}{l}\mathrm{MWd} / \mathrm{kg} \\
\text { or } \mathrm{GWd} / \mathrm{t}\end{array}$ & \\
\hline $\begin{array}{l}\text { Average Boron acid }\left(\mathrm{H}_{3} \mathrm{BO}_{3}\right) \\
\text { concentration }{ }^{\mathrm{a}} \text { in coolant }\end{array}$ & $\begin{array}{c}\mathrm{Cb} \text { or } \\
\mathrm{C}_{\mathrm{H} 3 \mathrm{BO} 3}\end{array}$ & $\begin{array}{l}\mathrm{ppm} \\
\text { or } \mathrm{g} / \mathrm{kg}\end{array}$ & $\begin{array}{l}\mathrm{H}_{3} \mathrm{BO}_{3} \text { fraction in coolant (unit "ppm" means } \\
\text { mg of boron acid in } 1 \mathrm{Kg} \text { of } \mathrm{H}_{2} \mathrm{O} \text { ) }\end{array}$ \\
\hline Critical boron acid concentration in coolant & $\mathrm{Cb}^{\text {crit }}$ & $\begin{array}{c}\text { ppm } \\
\text { or } \mathrm{g} / \mathrm{kg}\end{array}$ & $\mathrm{Cb}\left(\mathrm{C}_{\mathrm{H} 3 \mathrm{BO} 3}\right)$ value ensuring $\mathrm{Keff}=1$ \\
\hline 2-D power distribution in $\mathrm{CS}$ & $\mathrm{q}_{\mathrm{k}}-\mathrm{CS}$ & & $\begin{array}{l}\text { Power of fuel pins normalised by average fuel } \\
\text { pin power in CS. }\end{array}$ \\
\hline $\begin{array}{l}\text { Peaking factor of 2-D power distribution } \\
\text { in } \mathrm{CS}\end{array}$ & $\mathrm{K}_{\mathrm{FA}}-\mathrm{CS}$ & & Maximum in $\mathrm{q}_{\mathrm{k}}$-CS values \\
\hline 2-D power distribution in assembly & $\mathrm{q}_{\mathrm{k}}$ & & $\begin{array}{l}\text { Power of fuel pins normalised by average fuel } \\
\text { pin power in assembly (in some axial fraction). }\end{array}$ \\
\hline 3-D power distribution in axial volumes & $\mathrm{q}_{\mathrm{ijk}}$ & & Power of axial volumes of fuel pins normalised \\
\hline
\end{tabular}

\footnotetext{
${ }^{a}$ Boron acid concentration divided by the coefficient 5.72 means natural boron (nat B) concentration. In VVER-1000 calculations the term of boron acid concentration is widely used. Below, $\mathrm{Cb}$ means boron acid concentration if there is no special indication.
} 
RUSSIAN RESEARCH CENTER KURCHATOV INSTITUTE

Design Studies of "Island" Type MOX Lead Test Assembly (Report for FY99)

\begin{tabular}{|c|c|c|c|}
\hline of fuel pins in core & & & $\begin{array}{l}\text { by average power in such volumes over a whole } \\
\text { core }\end{array}$ \\
\hline Pin power peaking factor in assembly & Kki & & $\begin{array}{l}\text { Among } \mathrm{q}_{\mathrm{k}} \text { values for an assembly number } \mathrm{i} \text { for a } \\
\text { fraction number } \mathrm{j} \text { where maximum } \mathrm{q}_{\mathrm{ij}} \text { for this } \\
\text { assembly is realised. }\end{array}$ \\
\hline Radial pin power peaking factor & $\mathrm{Kr}$ & & $\max \left(\mathrm{qi}^{*} \mathrm{Kki}\right)$ \\
\hline $\begin{array}{l}\text { Radial position of radial pin power } \\
\text { peaking factor }\end{array}$ & $\mathrm{N}(\mathrm{Kr})$ or $\mathrm{N}_{\mathrm{K}}$ & & $\begin{array}{l}\text { Number of assembly in calculational core } \\
\text { sector where } \mathrm{Kr} \text { is realised }\end{array}$ \\
\hline 2-D power peaking factor in assembly & $\begin{array}{c}\mathrm{K}_{\mathrm{FA}} \\
\text { (in Russian } \\
\text { exploitation } \\
\text { calculations the } \\
\text { notation } \mathrm{Kk} \text { or } \\
\mathrm{Kk}_{\text {max is also }} \\
\text { used) } \\
\end{array}$ & & $\begin{array}{l}\text { Maximum relative power of fuel pins } \\
\text { (maximum in } \mathrm{q}_{\mathrm{k}} \text { values) }\end{array}$ \\
\hline $\begin{array}{l}\text { Axial power peaking factor in assembly } \\
\text { or in fuel pin }\end{array}$ & $\mathrm{Kz}$ & & $\begin{array}{l}\text { Maximum relative power of axial volume in } \\
\text { assembly or in fuel pin normalised by average } \\
\text { power in such volumes (in assembly or in fuel pin) }\end{array}$ \\
\hline Total power peaking factor & Ko or $\mathrm{K}_{\text {o-total }}$ & & $\begin{array}{l}\max \left(\mathrm{q}_{\mathrm{ij}} * \mathrm{Kki}\right)=\mathrm{Kr}{ }_{\mathrm{ij}}^{*} \mathrm{Kz} \\
\end{array}$ \\
\hline $\begin{array}{l}\text { Radial position of total power peaking } \\
\text { factor }\end{array}$ & $\begin{array}{l}\mathrm{N}\left(\mathrm{K}_{\mathrm{o} \text {-total }}\right) \text { or } \\
\mathrm{N}_{\mathrm{K}}\end{array}$ & & $\begin{array}{l}\text { Number of assembly in calculational core } \\
\text { sector where } \mathrm{K}_{\mathrm{o} \text {-total }} \text { is realised }\end{array}$ \\
\hline $\begin{array}{l}\text { Axial position of total power peaking } \\
\text { factor }\end{array}$ & $\begin{array}{l}\mathrm{M}\left(\mathrm{K}_{\mathrm{o} \text {-total }}\right) \text { or } \\
\mathrm{N}_{\mathrm{Z}}\end{array}$ & & Number of axial level where $\mathrm{K}_{\mathrm{o} \text {-total }}$ is realised \\
\hline Engineering factor & $\mathrm{K}_{\text {eng }}$ & & $\begin{array}{l}\text { Coefficient taking account of uncertainty of a } \\
\text { hot point (maximum fuel pin local power) } \\
\text { calculations }\end{array}$ \\
\hline 2-D burnup distribution in assembly & BUk & $\begin{array}{l}\mathrm{MWd} / \mathrm{kg} \\
\text { or } \mathrm{GWd} / \mathrm{t}\end{array}$ & Average-pin burnup distribution in CS. \\
\hline
\end{tabular}


RUSSIAN RESEARCH CENTER KURCHATOV INSTITUTE

Design Studies of "Island" Type MOX Lead Test Assembly (Report for FY99)

\begin{tabular}{|c|c|c|c|}
\hline 1-D burnup distribution in fuel pin & BUpin & & $\begin{array}{l}\text { Burnup distribution in concentric zones of } \\
\text { equal volume in fuel pin, normalised by average } \\
\text { zone burnup. }\end{array}$ \\
\hline 1-D power distribution in fuel pin & $q_{p i n}$ & & $\begin{array}{l}\text { Power distribution in concentric zones of equal } \\
\text { volume in fuel pin, normalised by average zone } \\
\text { power. }\end{array}$ \\
\hline Regulation bank position & $\mathrm{H}_{\mathrm{reg}}$ & $\mathrm{cm}$ & Distance from core bottom till rods lower edge \\
\hline Control rods worth (in core) & $(\mathrm{RO})_{\mathrm{AP}-1}$ & ppm & $\begin{array}{l}\text { Effect of control rods insertion in core } \\
\text { supposing the most effective single CR stuck in } \\
\text { upper position. } \\
\text { It is defined as a reactivity difference in two } \\
\text { states: } \\
\text { (RO) } \mathrm{AP-1}=\mathrm{RO} 1-\mathrm{RO} 2 \text {. } \\
\text { The second state differs from the first one only } \\
\text { by additional CRs inserted in core. All the other } \\
\text { parameters correspond to the first state: Cb (that is } \\
\text { equal to Cb crit for the first state), temperature and } \\
\text { FP distribution in core. }\end{array}$ \\
\hline Repeat Criticality Temperature & RCT & ${ }^{\circ} \mathrm{C}$ & $\begin{array}{l}\text { Temperature that ensures a secondary critical state } \\
\text { during core cooling in EOC in such conditions: all } \\
\text { control rods inserted in core except one the most } \\
\text { effective, zero boron concentration, equilibrium } \\
\text { xenon concentration corresponding to reactor } \\
\text { power before its shut-down. }\end{array}$ \\
\hline Moderator temperature coefficient (in core) & MTC & $\mathrm{pcm} /{ }^{\circ} \mathrm{C}$ & \\
\hline Moderator density coefficient (in core) & MDC & $\mathrm{pcm} / \mathrm{g} / \mathrm{cc}$ & \\
\hline Doppler temperature coefficient (in core) & DTC & $\mathrm{pcm} /{ }^{\circ} \mathrm{C}$ & $\begin{array}{l}\text { Calculated supposing average fuel temperature } \\
\text { changing of } 1^{\circ} \mathrm{C}\end{array}$ \\
\hline $\begin{array}{l}\text { Doppler isotermic temperature coefficient } \\
\text { (in core) }\end{array}$ & DTC* & $\mathrm{pcm} /{ }^{\circ} \mathrm{C}$ & $\begin{array}{l}\text { Calculated supposing local fuel temperature } \\
\text { changing of } 1^{\circ} \mathrm{C}\end{array}$ \\
\hline
\end{tabular}


RUSSIAN RESEARCH CENTER KURCHATOV INSTITUTE

Design Studies of "Island" Type MOX Lead Test Assembly (Report for FY99)

\begin{tabular}{|c|c|c|c|}
\hline Doppler power coefficient (in core) & DPC & $\mathrm{pcm} / \mathrm{MW}$ & \\
\hline Boron reactivity coefficient (in core) & $\mathrm{DRO} / \mathrm{DCB}$ & $\mathrm{pcm} / \mathrm{ppm}$ & \\
\hline Effective fraction of delayed neutrons & $\beta$ eff or $\beta_{\text {ef. }}$ & ppm & General characteristic of infinite grid or core \\
\hline Lifetime of prompt neutrons & $\lambda_{\mathrm{m}}$ or $\lambda_{\mathrm{im}}$ & $\mathrm{s}$ & General characteristic of infinite grid or core \\
\hline Reactor thermal power & $\mathrm{W}$ & MW & \\
\hline Specific reactor thermal power in CS & Wv & KW/litre & Reactor thermal power in CS volume unit \\
\hline Nominal reactor thermal power & Wnom & MW & Equal to $3000 \mathrm{MW}$ for VVER-1000 \\
\hline $\begin{array}{l}\text { Minimum controllable level of reactor } \\
\text { power }\end{array}$ & MCL & MW & $\begin{array}{l}\text { In calculations corresponds to Zero Power and } \\
\text { uniform temperature } 280^{\circ} \mathrm{C} \text { in core. }\end{array}$ \\
\hline Core coolant flow rate & $\mathrm{G}$ & $\mathrm{m}^{3} / \mathrm{h}$ & \\
\hline Average entry core temperature & $t_{\text {entry }}$ & ${ }^{\circ} \mathrm{C}$ or $\mathrm{K}$ & \\
\hline Average outer core temperature & $t_{\text {out }}$ & ${ }^{\circ} \mathrm{C}$ or $\mathrm{K}$ & \\
\hline $\begin{array}{l}\text { Average coolant-moderator temperature in } \\
\text { CS }\end{array}$ & $t_{\text {mod }}$ & ${ }^{\circ} \mathrm{C}$ or $\mathrm{K}$ & \\
\hline $\begin{array}{l}\text { Average Coolant-moderator density in } \\
\mathrm{CS}\end{array}$ & $\gamma_{\bmod }$ & $\mathrm{g} / \mathrm{cm}^{3}$ & \\
\hline Fuel temperature & $t_{\text {fuel }}$ & $\mathrm{K}$ & \\
\hline $\begin{array}{l}\text { Average temperature of other CS } \\
\text { components }\end{array}$ & $t_{\text {con }}$ & ${ }^{\circ} \mathrm{C}$ or $\mathrm{K}$ & \\
\hline Fuel pin cladding temperature & $\mathrm{t}_{\text {clad }}$ & ${ }^{\circ} \mathrm{C}$ or $\mathrm{K}$ & \\
\hline $\begin{array}{l}\text { Xenon-135 concentration distribution in } \\
\text { core }\end{array}$ & $\mathrm{Xe}$ & $10^{24} / \mathrm{cc}$ & $\begin{array}{l}\text { For } 1 \mathrm{cc} \text { in fuel. } \\
\mathrm{Xe}=0 \rightarrow \text { xenon is absent; } \\
\mathrm{Xe}=1 \rightarrow \mathrm{Xe}=\mathrm{Xe} \text { eq }(\mathrm{W})\end{array}$ \\
\hline $\begin{array}{l}\text { Equilibrium Xenon-135 concentration } \\
\text { distribution in core }\end{array}$ & $\mathrm{Xe}$ eq $(W)$ & $10^{24} / \mathrm{cc}$ & $\begin{array}{l}\text { Concentration formed during long working with } \\
\text { W power, regulating bank in nominal position }{ }^{b}\end{array}$ \\
\hline Sm-149 concentration distribution in core & $\mathrm{Sm}$ & $10^{24} / \mathrm{cc}$ & $\begin{array}{l}\text { For } 1 \mathrm{cc} \text { in fuel. } \\
\mathrm{Sm}=0 \rightarrow \text { samarium is absent, } \\
\mathrm{Sm}=1 \rightarrow \mathrm{Sm}=\mathrm{Sm} \mathrm{eq}\end{array}$ \\
\hline
\end{tabular}

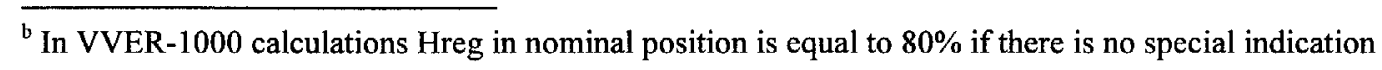


RUSSIAN RESEARCH CENTER KURCHATOV INSTITUTE

Design Studies of "Island" Type MOX Lead Test Assembly (Report for FY99)

\begin{tabular}{|c|c|c|c|}
\hline & & & $\begin{array}{l}\mathrm{Sm}=3 \rightarrow \text { full decay of Pm-149 into Sm-149 is } \\
\text { simulated in BOC. }\end{array}$ \\
\hline $\begin{array}{ll}\text { Equilibrium Sm-149 } & \text { concentration } \\
\text { distribution in core } & \end{array}$ & Sm eq & $10^{24} / \mathrm{cc}$ & $\begin{array}{l}\text { Concentration formed during long working, } \\
\text { regulating bank in nominal position }\end{array}$ \\
\hline $\begin{array}{l}\text { Samarium-149 concentration distribution, all } \\
\text { Prometium- } 149 \text { decayed in Sm }\end{array}$ & Smh & $10^{24} / \mathrm{cc}$ & \\
\hline Core reactivity while reactor shut-down & $\mathrm{RO}_{\text {STOP }}$ & $\mathrm{pcm}$ & $\begin{array}{l}\text { Under conditions: } \mathrm{W}=0, \mathrm{Xe}=0, \mathrm{Sm}=\mathrm{Smh} \text {, } \\
\mathrm{t}_{\text {mod }}=\mathrm{t}_{\text {fuel }}=\mathrm{t}_{\text {con }}=20^{\circ} \mathrm{C}, \\
\mathrm{Cb}=16000 \mathrm{ppm}\end{array}$ \\
\hline
\end{tabular}




\section{Parametric Studies of MOX LTA design (Stage "Assembly")}

\subsection{Calculational Model. General features}

Calculational system (CS) for MOX LTA design parametric studies is presented by two principal options:

- infinite grid of single plutonium or uranium assemblies;

- infinite grid of central plutonium assemblies surrounded by uranium assemblies of $3.7 \% \mathrm{Wt}$. U-235. The $60^{\circ}$ sector of CS for different options of MOX LTA design is shown in Figures 2.6 (for 100\% Plutonium MOX LTA that is not the case of the Report), 2.8 ("Island-1") and 2.10 ("Island-2").

Composition of weapons grade plutonium, adopted for calculations, is presented in Table 2.1. The design parameters of plutonium and uranium assemblies are described in Tables 2.2-2.6.

The calculational model includes two principal regimes described in p.2.1.1 and 2.1.2.

\subsubsection{Fuel Irradiation Simulation}

This regime is used for MOX LTA zoning studies under the conditions described in [2]. They comprise irradiation simulation in CS as a rule on the interval [0-40 MWd/kg] with the step $2 \mathrm{MWd} / \mathrm{kg}$.

In the process of irradiation:

- Axial buckling is $1 . \mathrm{E}-4 \mathrm{~cm}^{-2}$. A set of calculations has been executed with a critical buckling ensuring Keff $=1$;

- $\quad \mathrm{Cb}($ nat $\mathrm{B})=600 \mathrm{ppm}$. A set of calculations for zero irradiation has been executed with $\mathrm{Cb}=0$ and $\mathrm{Cb}$ (nat.B) $=1200 \mathrm{ppm}$;

- $\quad \mathrm{Wv}=108 \mathrm{KW} /$ litre;

- $\mathrm{t}_{\mathrm{mod}}=302^{\circ} \mathrm{C}$

- $\quad t_{\text {con }}=302^{\circ} \mathrm{C}$;

- $\quad \mathrm{t}_{\text {fuel }}=1027 \mathrm{~K}$;

- $\quad \mathrm{Xe}=\mathrm{Xe}$ eq;

- $\mathrm{Sm}=\mathrm{Sm}$ eq.

\subsubsection{Zero Power Calculations}

This regime is aimed to define reactivity effects due to temperature and $\mathrm{Cb}$ variations and to compare Keff with eventual verification calculations to be carried out by other codes.

Calculations are executed in five irradiation points:

$0,10,20,30,40 \mathrm{GWd} / \mathrm{t}$

where states are to be formed by different combinations of the following values:

$\mathrm{Cb}$ (nat.B): $0,600,1200 \mathrm{ppm}$;

$\mathrm{t}_{\text {mod }}=\mathrm{t}_{\text {con }}=\mathrm{t}_{\text {fuel }}: 20,280^{\circ} \mathrm{C}$. 


\subsection{Calculations of «Island» Type MOX LTA. Details}

In these calculations the size of «Island» in the center of assembly has been fixed: 54 plutonium fuel pins i.e. 4 pin rows. Two options of «Island» have been considered:

- $\quad$ one-zone island or "Island-1"(Figure 2.7);

- two-zones island or "Island-2"(Figure 2.9).

The studies are divided into three parts:

1. Studies of infinite grid of fresh MOX LTA by means of plutonium content variation to ensure an acceptable value of power peaking factor $\mathrm{Kk}$. Axial buckling in this case was variable to provide $\mathrm{Keff}=1$.

2. Calculation of CS where MOX LTA or Uranium FA is surrounded by uranium assemblies, for zoning option chosen in the previous part. In this part plutonium/uranium fuel irradiation has been simulated with fixed axial buckling.

3. Studies of infinite grid of plutonium assemblies for zoning option chosen in the first part. Axial buckling in this case was variable to provide $\mathrm{Keff}=1$. In this part plutonium/uranium fuel irradiation has been simulated. Inter-pin isotopic and power distributions have been calculated. The comparison of different spectrum parameters has been also made for a number of combinations of uranium and plutonium fuel enrichments.

Two levels of acceptable values of power peaking factor $\mathrm{Kk}$ have been considered:

- $\mathrm{Kk}=1.20$

- $\mathrm{Kk}=1.15$.

This rather high value of $\mathrm{Kk}=1.20$ was considered in the hope that a proper choice of MOX LTA location in core (at the stage "Core") could lead to rather low power values $q_{i}$ in MOX LTA and finally to acceptable values of overcore power peaking factors.

Uranium zone enrichment inside MOX LTA was equal to $3.7 \%$ as a base. In some calculations the option of $4.4 \%$ has been also considered.

\subsection{1. "Island-1" option}

The studies for uranium zone enrichment of $3.7 \%$ have shown (Figure 2.14) that fissile plutonium content in plutonium zone cannot exceed:

- $2.4 \%$ if $\mathrm{Kk}$ maximum is 1.15 ;

- $2.7 \%$ if $\mathrm{Kk}$ maximum is 1.20 .

These values are too low to justify practical using of "Island-1" option in this case. 
For uranium zone enrichment of $4.4 \%$, fissile plutonium content in plutonium zone cannot exceed (Figure 2.15):

- $3.0 \%$ if $\mathrm{Kk}$ maximum is 1.15 ;

- $3.4 \%$ if $\mathrm{Kk}$ maximum is 1.20 .

For the 3\% plutonium enrichment Fig.2.24 shows the comparison of interassembly row-by-row power distribution for the Uranium zone enrichments of $3.7 \%$ and $4.4 \%$ with different boron concentrations in coolant $\mathrm{Cb}$ (nat) of 0 and $1200 \mathrm{ppm}$. It is seen that maximum power is attained in Plutonium rods in the last (fifth) "Island" row. The same conclusion can be made from Fig. 2.25 with $4 \%$ Plutonium central part.

\subsection{2. "Island-2" option}

Results of parametric calculations of "Island-2" option have allowed to obtain the pares of plutonium content values in two plutonium zones which could ensure the acceptable value of $\mathrm{Kk}$. The Figures 2.14 and 2.15 (correspondingly for uranium zone enrichment of $3.7 \%$ and of $4.4 \%$ ) allow to choose fissile plutonium content ensuring optimum (i.e. minimum) $\mathrm{Kk}$ values.

The Figures 2.16 and 2.17 show coolant boron concentration influence on optimal values of plutonium enrichment. It is seen that optimal location does not vary significantly.

The Figures 2.18 and 2.19 show row-by-row evolution of maximum relative cell power $\mathrm{W}$. The boron concentration $\mathrm{Cb}$ (nat) is equal to $1200 \mathrm{ppm}$. It is seen from Fig.2.18, that in the case of $4 \%$ Plutonium central part, the cell powers in the interior of "Island" exceed the ones in the Uranium region. Besides for the periphery enrichment of $2.5 \%$ and $3 \%$ the maximum power is located in the forth row and for the periphery enrichment of $3.2 \%, 3.5 \%$ and $4 \%$ it is replaced to the fifth row (peripheral "Island" row).

If the Uranium zone enrichment is equal to $4.4 \%$ (Figures 2.20 and 2.21 ) the power in peripheral assembly can exceed the one in the assembly central part as it is seen from the Fig. 2.21 with $3 \%$ Plutonium in the "Island" central part. The Figures 2.22 and 2.23 complete this conclusion showing the comparison of different uranium zone MOX LTAs (3.7\% and 4.4\%). Peripheral enrichment is supposed optimal i.e. with minimum $\mathrm{Kk}$ and the central part Plutonium enrichment is of 4\% (Fig.2.22) and 3\% (Fig.2.23).

Finally, the chosen zoning is the pair " $3.8 \%$ in the central part $-2.8 \%$ in the island periphery" with uranium environment of $3.7 \%$. In this case, the acceptable power peaking factor, as well as Ko values, close to the reference uranium CS, have been ensured according to Figures 2.12 and 2.13.

The results of calculations simulating fuel irradiation are presented in Table 2.10 (MOX assembly) and in Tables 2.8 and 2.9 (UOX assembly correspondingly without and with Boron BPRs). Calculations in zero power states are presented in Table 2.7. 
RUSSIAN RESEARCH CENTER KURCHATOV INSTITUTE

Design Studies of "Island" Type MOX Lead Test Assembly (Report for FY99)

\subsection{3 "Plutonium island" size variation}

Increased size of "Plutonium Island» that comprises 6 plutonium rows (Fig.2.26) has been also considered. In Fig.2.27 and 2.28 the central plutonium enrichment has been fixed by $4 \%$ while considering two uranium environment enrichments: $3.7 \%$ and $4 \%$. The Figures 2.27 and 2.28 shows an optimum plutonium periphery enrichment about $3 \%$ where $\mathrm{Kk}$ minimum is reached.

\subsubsection{Inter-pin isotopic content and power distribution}

Inter-pin isotopic content and power distributions are of interest for thermo-hydraulic analysis of MOX fuel behavior. TVS-M allows obtaining of these parameters for 5 concentric zones that have been chosen of equal volumes in current calculations. In Fig.2.29-2.40 they are presented for some character pins:

- near central instrumentation tube (as No 77 in Fig.2.18),

- near water tube (as No 76 in Fig.2.18),

- on the border of different «Island-2» enrichments (as No 75 in Fig.2.18),

- on the «Island-2» periphery (as No 74 in Fig.2.18),

- in uranium fuel pin (as No 72 in Fig.2.18).

The following moments while fuel burning have been considered: $0,12,24$ and 40 $\mathrm{MWd} / \mathrm{kg}$.

Figures 2.29 and 2.30 show correspondingly inter-pin relative burnup and power distributions $\mathrm{BU}_{\text {pin }}$ and $\mathrm{q}_{\text {pin. }}$. Figures 2.31-2.40 show correspondingly inter-pin distribution of $\mathrm{U}_{235}, \mathrm{PU}_{239}, \mathrm{PU}_{240}, \mathrm{PU}_{241}, \mathrm{PU}_{242}$ for two irradiation levels: 12 and 40 $\mathrm{MWd} / \mathrm{kg}$ that corresponds approximately to fuel discharged after one and three years of reactor exploitation.

\subsubsection{Spectrum characteristics analysis}

Usually, more reliable results of treatment of experimental data on fuel pin burning can be obtained if fuel irradiation takes place in the neutron spectrum close to the asymptotic one. It can be seen in Figures 2.41-2.43 that in two internal rows of plutonium island " $3.8 \%$ in the central part $-2.8 \%$ in the island periphery" the spectrum is close to the one taking place in $100 \%$ Plutonium MOX LTA with the enrichment of $3.8 \%$. So fuel fins located in these positions is reasonable to use for plutonium fuel investigation in the case of «Island-2» type MOX LTA design.

Relative power distributions are shown in Figures 2.44 and 2.45 for the following moments while fuel burning $0,12,24$ and $40 \mathrm{MWd} / \mathrm{kg}$. 
RUSSIAN RESEARCH CENTER KURCHATOV INSTITUTE

Design Studies of "Island" Type MOX Lead Test Assembly (Report for FY99)

Relative burnup distributions are shown in Fig.2.46 for the following moments while fuel burning: 12,24 and $40 \mathrm{MWd} / \mathrm{kg}$.

Evolution of average assembly neutron absorption and fission cross-sections while fuel burning is presented in Fig. 2.47 for a number of plutonium and uranium enrichment compositions.

Evolution of multiplication factor Ko and power peaking factor $\mathrm{Kk}$ while fuel burning is presented in Fig.2.48 for a number of plutonium and uranium enrichment compositions.

In Figures 2.49-2.54 the evolution of $\mathrm{U}_{235}, \mathrm{PU}_{239}, \mathrm{PU}_{240}, \mathrm{PU}_{241}, \mathrm{PU}_{242}$ and $\mathrm{Am}_{241}$ content while fuel burning is presented for a number of plutonium and uranium enrichment compositions. 


\section{CALCULATIONS OF VVER-1000 CORE WITH 3 MOX LTAs (Stage "Core")}

These studies comprise:

- "Uranium Core". Calculation of the so-called Advanced VVER-1000 core with boron BPRs for the equilibrium fuel cycle [2] that was defined as basic for 3 MOX LTAs introduction.

- "MOX Core". Studies of VVER-1000 core with introduction of 3 MOX LTAs of "Island-2" design with the zoning chosen in Chapter 2. Three cycles till MOX LTAs discharge have been studied. Corresponding loading patterns for every cycle have been chosen to minimize power peaking factors.

"Uranium core" loading pattern is shown in Fig.3.1. This figure includes particularly the reloading scheme (the FA locations in previous fuel cycle are indicated), the FA locations in current equilibrium cycle with the indication of its type (according to Figures 2.1, 2.3 and 2.4) and initial average assembly burnups.

The core, FA, fuel pins, $\mathrm{CR}$ and Boron BPR geometric and material parameters are indicated in Tables 2.1-2.6.

The reflectors are described in Annex.

\subsection{Limitations}

\section{Safetv limitations}

Composed core loading patterns must meet a number of safety requirements.

Tables 3.1 and 3.2 present the requirements that are officially adopted nowadays for VVER-1000 Uranium cores.

For MOX fueled cores the limitations, not yet officially established, have been conventionally strengthened for power peaking factors and RCT. They are presented in Tables 3.3 and 3.4. It was tried to meet these conventional requirements either for MOX LTAs only (it concerns power peaking factors) or for the core (it concerns RCT).

\section{Other limitations}

3 MOX LTA are placed in the core under the following conditions:

- respect $120^{\circ}$ symmetry;

- not to occupy the positions without in-core measurement system (the self-powered detectors are shown in Fig. 3.6);

- it is desirable to place MOX assemblies symmetrically to the uranium ones that are equipped by detectors. 


\subsection{Fuel Irradiation Simulation}

Irradiation of the fuel loading is simulated with the step 20 EFPD. Cb crit is found in sequence (below these values are named " $\mathrm{Cb}$ burnup") until reactivity margin reaches 0 , i.e. $\mathrm{Cb}$ crit becomes 0 . This moment defines $\mathrm{T}$ cycle - a value of cycle length usually presented in EFPD unit.

In the process of irradiation:

- Regulating Bank N 10 (Figure 3.6) is 20\% inserted in core; other banks are out of core;

- $\mathrm{W}=\mathrm{Wnom}(3000 \mathrm{MW})$;

- $t_{\text {entry }}=287^{\circ} \mathrm{C}$;

- Xe=Xe eq;

- At the beginning of irradiation $\mathrm{Sm}=\mathrm{Smh}$.

At the stage "MOX core", while studying of acceptable MOX location in the Uranium loading pattern (Fig.3.1), calculations of three successive cycles are carried out with corresponding description of reloading scheme.

\subsection{Calculational States}

The states that are considered at the stage "Core" are characterized by:

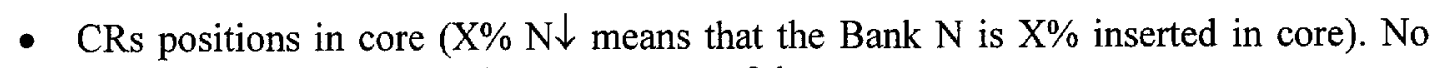
indication means that all the CRs are out of the core;

- $\mathrm{Cb}$;

- Average FP concentration in core (Xe-135 and Sm-149 poisoning are considered separately);

- Xe;

- Sm;

- W (in these studies two power levels are considered - $\mathrm{W}_{\text {nom }}$ и $\mathrm{MCL}$ );

- $t_{\text {mod; }}$

- $t_{\text {fuel }}$

- $t_{\text {con }}$.

It is necessary to remark that three last parameters are not generally independent.

All the states considered in the process of irradiation will be named "Burn-up".

The specific moments are introduced: the beginning of cycle (BOC) and the end of cycle (EOC). They characterize FP concentration (average in core) in these moments. It should be noted that the other above-mentioned parameters are not 
RUSSIAN RESEARCH CENTER KURCHATOV INSTITUTE

Design Studies of "Island" Type MOX Lead Test Assembly (Report for FY99)

always connected directly with irradiation conditions in these moments; their values may depend on reactor start-up conditions before irradiation or cooling conditions in the end of irradiation. 
RUSSIAN RESEARCH CENTER KURCHATOV INSTITUTE

Design Studies of "Island" Type MOX Lead Test Assembly (Report for FY99)

\subsection{Information Release}

The table below presents the states considered and the parameters calculated. The second column indicates the list of results presented in this report. The rest of calculated parameters and additional information can be received by addressing to Youri Styrine (email: Youri.Styrine@vver.kiae.ru). 
RUSSIAN RESEARCH CENTER KURCHATOV INSTITUTE

Design Studies of "Island" Type MOX Lead Test Assembly (Report for FY99)

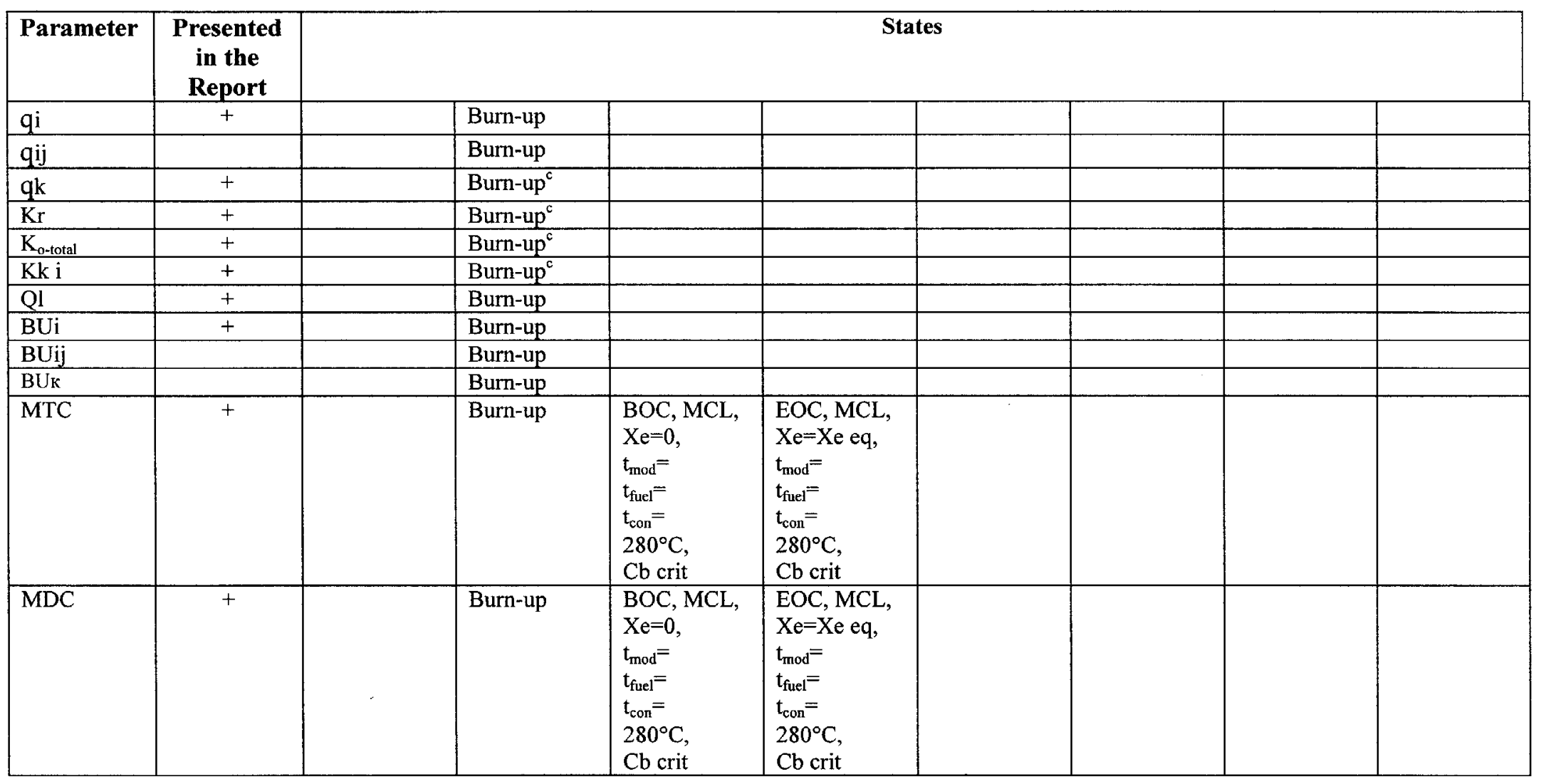

\footnotetext{
${ }^{c}$ For MOX assemblies and for an assembly with maximum qi.

${ }^{c}$ For MOX assemblies and for an assembly with maximum qi.

${ }^{c}$ For MOX assemblies and for an assembly with maximum qi.

${ }^{\circ}$ For MOX assemblies and for an assembly with maximum qi.
} 
RUSSIAN RESEARCH CENTER KURCHATOV INSTITUTE

Design Studies of "Island" Type MOX Lead Test Assembly (Report for FY99)

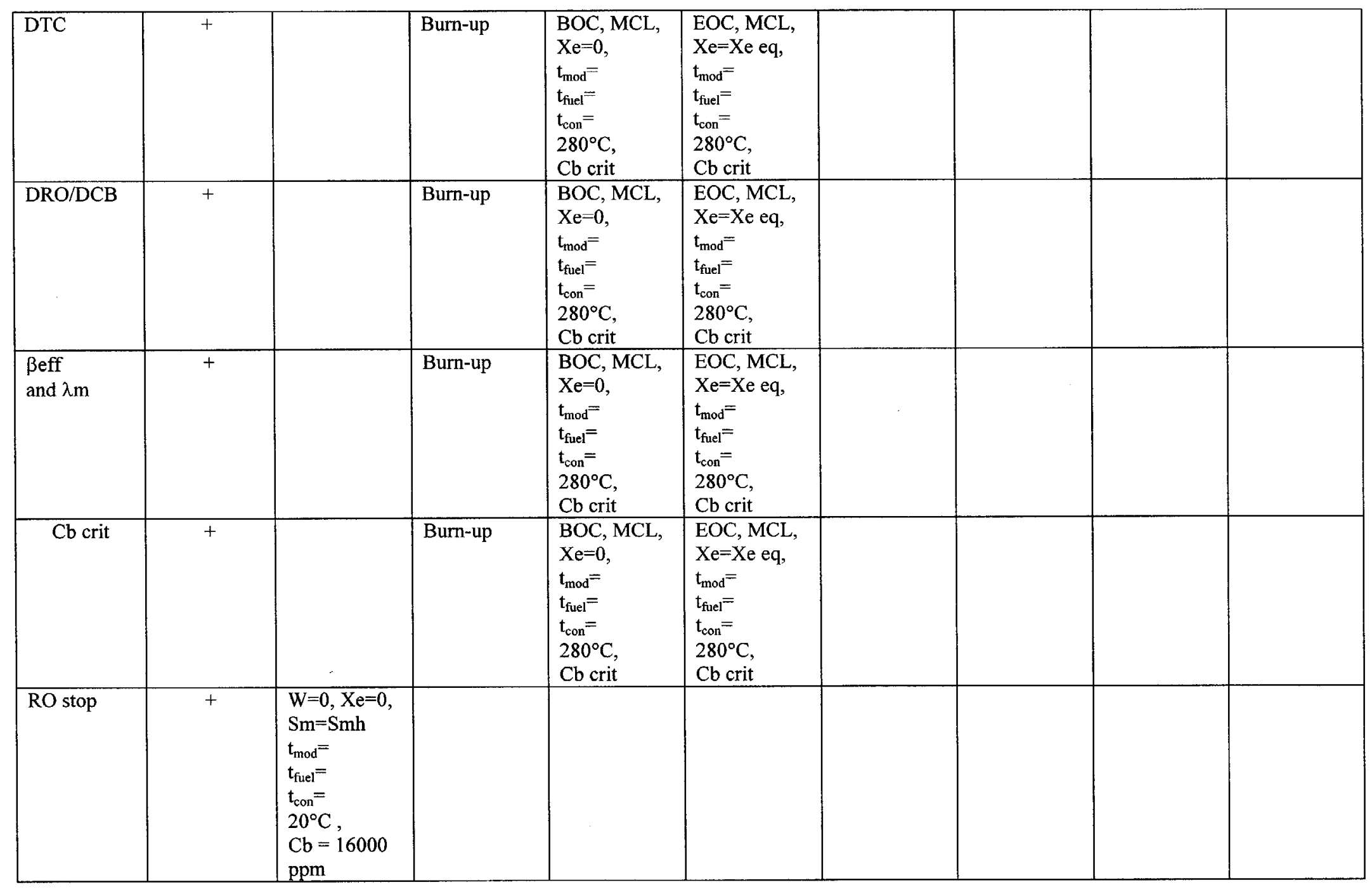


RUSSIAN RESEARCH CENTER KURCHATOV INSTITUTE

Design Studies of "Island" Type MOX Lead Test Assembly (Report for FY99)

\begin{tabular}{|c|c|c|c|c|c|c|c|c|c|}
\hline RCT & + & $\begin{array}{l}\text { EOC, MCL, } \\
\text { Xe }=X e \text { eq, } \\
\mathrm{t}_{\text {mod }}= \\
\mathrm{t}_{\text {fuel }}= \\
\mathrm{t}_{\text {con }}= \\
280^{\circ} \mathrm{C}, \\
\mathrm{Cb}=0, \\
100 \% 1-10 \downarrow \\
\text { (except of the } \\
\text { most effective } \\
\text { single } \mathrm{CR} \text { ) }\end{array}$ & & & & & & & \\
\hline$(\mathrm{RO})_{\mathrm{AP}-1}$ & + & 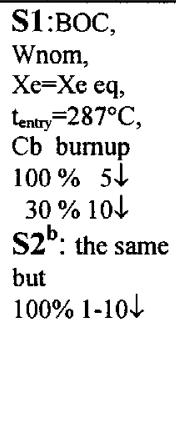 & $\begin{array}{l}\text { S1:BOC, } \\
\text { MCL, } \\
\text { Xe }=0, \\
t_{\text {entry }}=280^{\circ} \mathrm{C} \\
\text { Cb crit } \\
30 \% 10 \downarrow \\
\text { S2: the same } \\
\text { but } \\
100 \% 1-10 \downarrow\end{array}$ & $\begin{array}{l}\text { S1:BOC, } \\
\text { MCL, } \\
\text { Xe }=X e \text { eq, } \\
t_{\text {entry }}=280^{\circ} \mathrm{C} \\
\text { Cb crit } \\
30 \% 10 \downarrow \\
\text { S2: the same } \\
\text { but } \\
100 \% 1-10 \downarrow\end{array}$ & $\begin{array}{l}\text { S1:EOC, } \\
\text { Wnom, } \\
\text { Xe=Xe eq, } \\
t_{\text {entry }}=287^{\circ} \mathrm{C} \\
\text { Cb burnup } \\
100 \% 5 \downarrow \\
30 \% 10 \downarrow \\
\text { S2: the same } \\
\text { but } \\
100 \% 1-10 \downarrow\end{array}$ & $\begin{array}{l}\text { S1:EOC, } \\
\text { MCL, } \\
\text { Xe=Xe eq, } \\
t_{\text {entry }}=280^{\circ} \mathrm{C} \\
\mathrm{Cb} \text { crit } \\
100 \% 5 \downarrow \\
30 \% 10 \downarrow \\
\text { S2: the same } \\
\text { but } \\
100 \% 1-10 \downarrow\end{array}$ & $\begin{array}{l}\text { S1:EOC, } \\
\text { MCL, } \\
X \mathrm{e}=0, \\
\mathrm{t}_{\text {entry }}=280^{\circ} \mathrm{C} \\
\mathrm{Cb} \text { crit } \\
100 \% 5 \downarrow \\
30 \% 10 \downarrow \\
\text { S2: the same } \\
\text { but } \\
100 \% 1-10 \downarrow\end{array}$ & $\begin{array}{l}\text { S1:BOC, } \\
\text { Wnom, } \\
\mathrm{Xe}=\mathrm{Xe} \text { eq, } \\
\mathrm{t}_{\text {entry }}=287^{\circ} \mathrm{C}, \\
\mathrm{Cb} \text { burnup } \\
20 \% 10 \downarrow \\
\text { S2: the same } \\
\text { but with } \\
\text { successive } \\
\text { introduction of } \\
\text { the Banks } 1-9 \\
(0 \% \downarrow, 10 \% \downarrow, \\
20 \% \downarrow . \\
100 \% \downarrow)\end{array}$ & $\begin{array}{l}\text { S1:EOC, } \\
\text { Wnom, } \\
\mathrm{Xe}=\mathrm{Xe} \text { eq, } \\
\mathrm{t}_{\text {entry }}=287^{\circ} \mathrm{C} \\
\mathrm{Cb} \text { burnup } \\
20 \% 10 \downarrow \\
\text { S2: the same } \\
\text { but with } \\
\text { successive } \\
\text { introduction of } \\
\text { the Banks } 1-9 \\
(0 \% \downarrow, 10 \% \downarrow, \\
20 \% \downarrow \\
100 \% \downarrow)\end{array}$ \\
\hline
\end{tabular}

${ }^{\mathrm{b}}$ For all the states $\mathrm{S} 2$ : the most effective single $\mathrm{CR}$ is supposed stuck in upper position. 


\subsection{Calculational Results}

\subsubsection{Uranium Core}

The Table 3.5 and Fig. 3.1 show the results of kinetics parameters calculations for the equilibrium fuel cycle in the Uranium base core that have been performed by the code BIPR-7A ${ }^{\mathrm{a}}$.

The attained power peaking factors obtained by pin-by-pin code PERMAK-A are presented in Table 3.13. The linear pin powers for BOC and EOC are presented correspondingly in Figures 3.2 and 3.3. It is seen from combination of BIPR-7A and PERMAK-A calculations that maximum linear pin power in BOC is attained on level $4^{\mathrm{b}}$, in EOC - on level 2. It justifies PERMAK-A calculations to be performed as usual on level 4 (more details about PERMAK-A calculational scheme are described in Annex).

Pin-by-pin power distributions in the most powered assemblie for BOC and EOC are presented correspondingly in Figures 3.4 and 3.5.

Table 3.6 shows the parameters values in zero power states calculated by the code BIPR-7A.

It is seen that Uranium core meets the safety requirements presented in Tables 3.1 and 3.2 for power peaking factors and reactivity coefficients.

Table 3.15 a and 3.15 b show the CRs worth calculated with certain conservatism (the lowest possible position of Bank 5 that serves for offset regulation and of regulating Bank 10). It is seen that the limiting value of $5500 \mathrm{pcm}$ is respected.

Table 3.16 shows core reactivity evolution in the process of control rods simultaneous movement (when AP is actuated) from top to the bottom of core. BOC and EOC moments are considered including the situations when the most effective single control rod is stuck in upper position. In initial position all the banks except of Regulating bank 10 were in the upper position.

Table 3.17 shows the RCT value that is essentially lower than the allowable one in Table 3.1 .

Table 3.14 describes the scheme of conservative evaluation of core subcriticality (scram margin) after scram actuation and reactor state transformation from nominal power to MCL. The effects and uncertainties involved in this scheme (vapor effect, absorbent irradiation, uncertainty of CRs worth calculation etc.) correspond to ones adopted in the West, particularly, in the US and France.

\footnotetext{
a Temperature drop in Fig.3.1 is the difference between output and input coolant temperatures for an assembly considered as a channel.

${ }^{b}$ It should be reminded that the level numeration begins from the core bottom and the number of calculational levels in BIPR-7A was 10.
} 


\section{RUSSIAN RESEARCH CENTER KURCHATOV INSTITUTE \\ Design Studies of "Island" Type MOX Lead Test Assembly (Report for FY99)}

\subsubsection{MOX Core}

3 MOX assemblies have been located in uranium reference core according to the principals mentioned in p.3.1.

The positions 8, 88 and 150 for the first MOX loading (Fig.3.7) have been chosen because they possess self-powered detectors (see Fig.3.6). Other assemblies have been replaced to ensure a minimum value of $\mathrm{Kq}$ calculated by BIPR-7A. Besides, several fresh assemblies of "Ba" type (it is described in Fig.2.3) have been added to the first MOX loading. Reloading schemes for second and third cycles with 3 MOX LTAs of "Island-2" type are presented correspondingly in Figures 3.17 and 3.27.

The values of average assembly parameters calculated by the code BIPR-7A are presented for 3 successive fuel cycles in Figures 3.8-3.10 and Tables 3.7 (first cycle), Figures 3.18-3.20 and Tables 3.9 (second cycle), Figures 3.28-3.30 and Tables 3.11 (third cycle).

The attained power peaking factors obtained by pin-by-pin code PERMAK-A are presented in Table 3.13. The linear pin powers for BOC and EOC are presented correspondingly in Figures 3.11 and 3.12 (first cycle), Figures 3.21 and 3.22 (second cycle), Figures 3.31 and 3.32 (third cycle). Pin-by-pin power distributions in BOC and EOC both for the most powered assemblies and for MOX LTAs are presented in Figures 3.13-3.16 (first cycle), 3.23-3.26 (second cycle), 3.33-3.36 (third cycle).

Table $3.8,3.10$ and 3.12 show correspondingly the parameters values in zero power states for the first, the second and the third fuel MOX cycles calculated by the code BIPR-7A.

It is seen that MOX cores meet the safety requirements presented in Tables 3.13.4 for power peaking factors and reactivity coefficients.

Table $3.15 \mathrm{a}$ and $3.15 \mathrm{~b}$ show the CRs worth. It is seen that the conventional limiting value of $5500 \mathrm{pcm}$ (Table 3.3) is respected.

Table 3.16 shows core reactivity evolution in the process of AP actuation.

Table 3.17 shows the RCT values that are strongly lower than the conventional allowable value of $210^{\circ} \mathrm{C}$.

Table 3.14 describes the scheme of conservative evaluation of core subcriticality (scram margin).

It can be seen that the presence of $3 \mathrm{MOX}$ LTAs does not influence $(\mathrm{RO})_{\mathrm{AP}}$ in clear manner. Its value is determined first of all by core loading pattern. It may be supposed that only significant value of MOX assemblies in core could lead to lowering of control rods worth because of strong absorbing capacity of MOX fuel. 


\section{CONCLUSION}

The report presents the results of design studies of "Island" type MOX LTA:

- Parametric studies to define MOX LTA structure primarily to choose plutonium content in assembly zones that ensures reasonable power peaking factors and power generation equivalence in MOX and UOX assemblies.

- Studies of VVER-1000 core characteristics with 3 MOX LTAs introduced for three successive fuel cycles.

Plutonium «Island» with 54 plutonium pins in the center of MOX LTA has been considered in two modifications:

- uniform «Island» or "Island-1" option;

- $\quad$ graded «Island» with lower plutonium content in one peripheral row of pins or "Island-2" option.

It is shown that plutonium content in the uniform «Island» cannot exceed $2.7 \%$ because of adopted power peaking limitations and therefore this design seems unreasonable for practical use.

For graded «Island» the plutonium content composition $3.8 \% / 2.8 \%$ with uranium environment of $3.7 \% \mathrm{U}-235$ has been chosen.

Evolution of assembly power and burnup distributions, inter-pin power and isotopic distributions while fuel irradiating have been analyzed.

In addition to the base uranium environment of $3,7 \%$, a set of calculations has been executed for $4.4 \%$.

The studies has been executed by the code TVS-M that is at the final stage of licensing and it is to be used in the nearest future as a base instrument for VVER core calculations while using both uranium and MOX fuel.

VVER-1000 core with boron burnable control rods has been chosen as a base for 3 MOX LTAs introduction.

Fuel loadings with 3 MOX LTAs have been optimized to ensure a minimum value of power peaking factor $\mathrm{Kq}$.

Evolution of main neutronics parameters during 3 successive cycles with MOX LTAs is presented. It is shown that MOX loaded cores meet the safety requirements preliminary adopted for MOX fuel concerning power peaking factors, reactivity coefficients and control rods worth. 


\section{REFERENCES}

1. Y.A. Styrin. Fuel Assembly and Core Model for Neutronics Calculations of VVER-1000. Draft.

Moscow, Kurchatov Institute 1998.

2. Y.A. Styrin, I.K.Levina. Design of Lead Test MOX Assemblies for Pilot Irradiation in VVER-1000 and Related Parametric Studies. Draft.

Moscow, Kurchatov Institute 1998.

3. S.A. Bichkov, A.P.Lazarenko, V.D.Sidorenko, Y.A. Styrin. Results of Parametric Design Studies of MOX Lead Test Assembly (Final Report).

Moscow, Kurchatov Institute 1998.

4. V.D.Sidorenko et al. Spectral Code TBC-M for calculation of Characteristics of Cells, Super-cells and Fuel Assemblies of VVER-Type Reactors. 5-th Symposium of the AER.

5. Neutronics Benchmarks for the Utilisation of Mixed-Oxide Fuel: Joint U.S./Russian Progress Report for Fiscal Year 1997. Volume 3 - Calculations Performed in the Russian Federation. ORNL/TM-13603/V3.

6. Y.A. Styrin. Calculations of MOX LTA Performance in VVER-1000 Core. Moscow, Kurchatov Institute 1998.

7. In-core fuel management code package validation for WWERs. IAEATECDOC-847. November 1995.

8. Kaloinen E., Siltanen P., Terasvirta R. Two-group nodal calculations in hexagonal fuel assembly geometry. - In: Proc. of NFACRP Specialists' Meeting on Calculation of 3-D Rating Distributions in Operating Reactors. Paris, 1979. 
RUSSIAN RESEARCH CENTER KURCHATOV INSTITUTE

Design Studies of "Island" Type MOX Lead Test Assembly (Report for FY99)

Table 2.1. Composition of weapons grade plutonium

\begin{tabular}{|l|l|l|l|l|}
\hline \multicolumn{4}{|l|}{ Isotope / content (Wt. \%) } \\
\hline $\mathrm{Pu}-238$ & $\mathrm{Pu}-239$ & $\mathrm{Pu}-240$ & $\mathrm{Pu}-241$ & $\mathrm{Pu}-242$ \\
\hline 0.0 & 93.0 & 6.0 & 1.0 & 0.0 \\
\hline
\end{tabular}


RUSSIAN RESEARCH CENTER KURCHATOV INSTITUTE

Design Studies of "Island" Type MOX Lead Test Assembly (Report for FY99)

Table 2.2. Main Core Parameters

\begin{tabular}{|l|l|l|}
\hline Parameter & Units & Value \\
\hline Thermal Power & & \\
\hline Electrical Power & $\begin{array}{l}\text { MW } \\
\text { thermal }\end{array}$ & 3000 \\
\hline Number of Coolant Loops & $\mathrm{MW}$ & 1000 \\
\hline Number of Fuel Assemblies & & 4 \\
\hline Core Equivalent Diameter & $\mathrm{m}$ & 163 \\
\hline Core Fuel Height & $\mathrm{m}$ & 3.164 \\
\hline Core Volume & $\mathrm{m}^{3}$ & 3.53 \\
\hline Core Power Density & $\mathrm{W} / \mathrm{cm}^{3}$ & 27.8 \\
\hline Control / Shut off Rod Banks & & 108 \\
\hline Position of Regulating Rod Bank & $\%$ & 10 \\
\hline Core Coolant Flow Rate & $\mathrm{m}^{3} / \mathrm{hr}$ & 80 \\
\hline Pressure at Core Inlet & $\mathrm{MPa}$ & $\mathbf{8 4 0 0 0}$ \\
\hline Core Inlet Temperature & ${ }^{\circ} \mathrm{C}$ & 28.7 \\
\hline
\end{tabular}




\section{Table 2.3. Fuel Assembly Design Parameters}

\begin{tabular}{|l|c|c|}
\hline Parameter & Units & Value \\
\hline Shape of Fuel Assembly & & Hexagonal \\
\hline Distance Across Assembly (between flats) & $\mathrm{cm}$ & 23.4 \\
\hline Distance Between Fuel Assembly Centres & $\mathrm{cm}$ & $\mathbf{2 3 . 6}$ \\
\hline Fuel Pin Lattice Pitch & $\mathrm{cm}$ & 1.275 \\
\hline Number of Fuel Pins in Fuel Assembly & & $\mathbf{3 1 2}$ \\
\hline $\begin{array}{l}\text { Number of Guide Tubes for Control Rods } / \\
\text { Burnable Absorber Pins }\end{array}$ & & 18 \\
\hline Inner Diameter of Guide Thimbles & $\mathrm{cm}$ & 1.1 \\
\hline Thickness of Guide Thimbles & $\mathrm{cm}$ & $\mathbf{0 . 1}$ \\
\hline Material of Guide Thimbles & & Zirconium Alloy ${ }^{*}$ \\
\hline $\begin{array}{l}\text { Central Instrumentation Tube Inner } \\
\text { Diameter }\end{array}$ & $\mathrm{cm}$ & $\mathbf{1 . 1}$ \\
\hline Thickness of Central Instrumentation Tube & $\mathrm{cm}$ & $\mathbf{0 . 1}$ \\
\hline Material of Central Guide Tube & & Zirconium Alloy ${ }^{*}$ \\
\hline Number of Spacer Grids in Fuel Assembly & & 13 \\
\hline Material of Spacer Grids & & Kirconium Alloy \\
\hline Spacer Grid Weight (each) & & 0.55 \\
\hline
\end{tabular}

Compositions Weight percent:

\begin{tabular}{|c|c|c|}
\hline $\mathbf{Z r}$ & $\mathrm{Nb}$ & Hf \\
\hline 98.97 & 1.0 & $\mathbf{0 . 0 3}$ \\
\hline
\end{tabular}


RUSSIAN RESEARCH CENTER KURCHATOV INSTITUTE

Design Studies of "Island" Type MOX Lead Test Assembly (Report for FY99)

\section{Table 2.4. Uranium Fuel Pin Design Parameters}

\begin{tabular}{|c|c|c|}
\hline Parameter & Units & Value \\
\hline & & Advanced Core Design \\
\hline Inner Clad Diameter & $\mathbf{c m}$ & 0.772 \\
\hline Clad Thickness & $\mathbf{c m}$ & 0.069 \\
\hline Clad Material & & Zirconium Alloy* \\
\hline Clad Density & $g / c c$ & 6.5153 \\
\hline Fuel Pellet Diameter & $\mathbf{c m}$ & 0.755 \\
\hline Central Hole Diameter & $\mathrm{cm}$ & 0.15 \\
\hline Fuel Pellet Material & & L.E. UO2 \\
\hline Height of Fuel Column & $\mathbf{c m}$ & $\begin{array}{l}353 \text { (cold) } \\
355 \text { (hot) }\end{array}$ \\
\hline Mass of UO2 in Fuel Pin & kg & 1.575 \\
\hline
\end{tabular}

Compositions Weight percent:

$*$
\begin{tabular}{|l|l|l|}
\hline $\mathrm{Zr}$ & Nb & Hf \\
\hline 98.97 & 1.0 & 0.03 \\
\hline
\end{tabular}


RUSSIAN RESEARCH CENTER KURCHATOV INSTITUTE

Design Studies of "Island" Type MOX Lead Test Assembly (Report for FY99)

Table 2.5. MOX fuel Pin Design Parameters

\begin{tabular}{|l|c|c|}
\hline Parameter & Units & Value \\
\hline Inner Clad Diameter & $\mathrm{cm}$ & 0.772 \\
\hline Clad Thickness & $\mathrm{cm}$ & 0.069 \\
\hline Clad Material & & Zirconium Alloy \\
\hline Clad Density & $\mathrm{g} / \mathrm{cc}$ & 6.5153 \\
\hline Fuel Pellet Diameter & $\mathrm{cm}$ & 0.755 \\
\hline Central Hole Diameter & $\mathrm{cm}$ & $\mathbf{0 . 1 5}$ \\
\hline U-235 content in MOX fuel & $\%$ & 0.2 \\
\hline Fuel Pellet Material & & PuO2-UO2 \\
\hline Height of Fuel Column & $\mathrm{cm}$ & 353 (cold) \\
& & 355 (hot) \\
\hline Mass of MOX fuel in Fuel Pin & $\mathrm{kg}$ & 1.600 \\
\hline
\end{tabular}

Compositions Weight percent:

$*$
\begin{tabular}{|l|l|l|}
\hline $\mathbf{Z r}$ & Nb & Hf \\
\hline 98.97 & 1.0 & 0.03 \\
\hline
\end{tabular}


RUSSIAN RESEARCH CENTER KURCHATOV INSTITUTE

Design Studies of "Island" Type MOX Lead Test Assembly (Report for FY99)

Table 2.6. Discrete Burnable Poison Pin Design Parameters

\begin{tabular}{|c|c|c|c|}
\hline Parameter & Units & \multicolumn{2}{|c|}{ Value } \\
\hline Clad Inner Diameter & $\mathbf{c m}$ & \multicolumn{2}{|c|}{0.772} \\
\hline Clad Thickness & $\mathbf{c m}$ & \multicolumn{2}{|c|}{0.069} \\
\hline Clad Material & & \multicolumn{2}{|c|}{ Zirconium Alloy* } \\
\hline Clad Density & $\mathrm{g} / \mathrm{cc}$ & \multicolumn{2}{|c|}{6.5153} \\
\hline Absorber Diameter & $\mathbf{c m}$ & \multicolumn{2}{|c|}{0.758} \\
\hline Absorber Density & $\mathrm{g} / \mathrm{cc}$ & \multicolumn{2}{|c|}{2.945} \\
\hline Absorber Composition & & \multicolumn{2}{|c|}{ Boron g/ce } \\
\hline & & 0.036 & 0.065 \\
\hline B10 & $\mathbf{W t} \%$ & 0.2279 & 0.4046 \\
\hline B11 & & 1.0153 & 1.8028 \\
\hline $\mathbf{A l}$ & & 91.7424 & 88.5951 \\
\hline $\mathbf{F e}$ & & 0.1915 & 0.1850 \\
\hline $\mathbf{N i}$ & & 1.9153 & 1.8496 \\
\hline $\mathbf{C r}$ & & 2.9923 & 5.3133 \\
\hline $\mathbf{Z r}$ & & 1.9153 & 1.8496 \\
\hline
\end{tabular}

Compositions Weight percent:

\begin{tabular}{|l|l|l|}
\hline Zr & Nb & Hf \\
\hline 98.97 & 1.0 & 0.03 \\
\hline
\end{tabular}


Table 2.7. Keff in Zero Power States

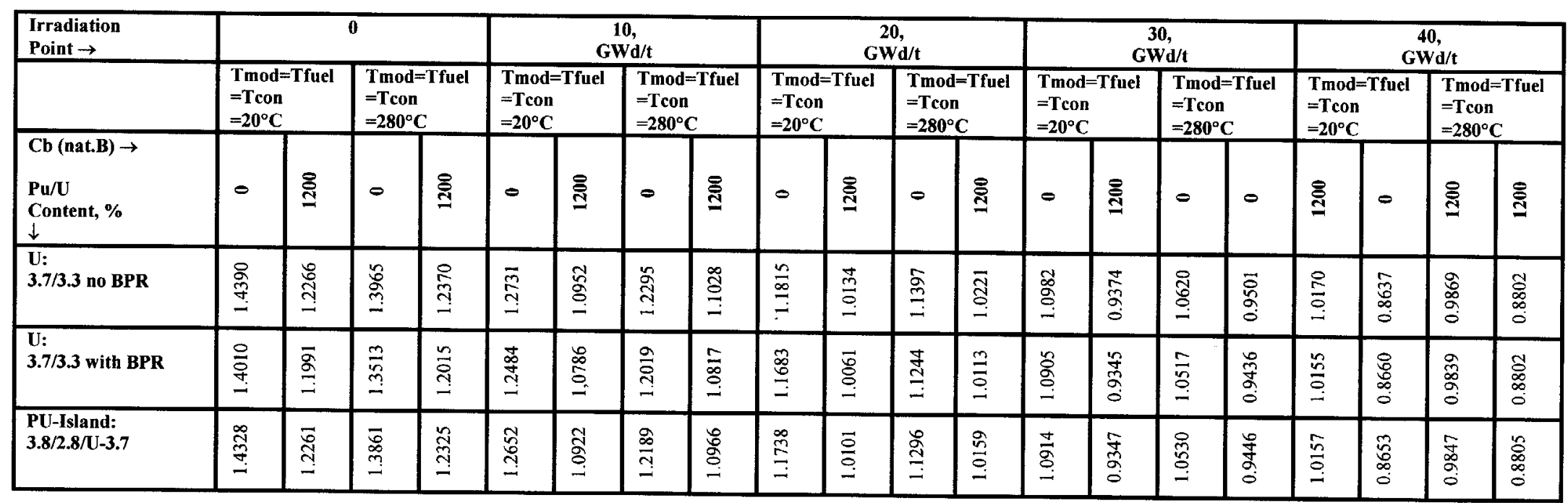


Table 2.8. Parameters Evolution in the Process of Fuel Irradiation. Reference Uranium Assemblage. No BPR

\begin{tabular}{|c|c|c|c|c|c|c|c|c|c|c|c|c|c|c|c|c|c|c|c|c|c|}
\hline $\begin{array}{c}\text { Irradiation } \\
\text { Point } \rightarrow\end{array}$ & \multicolumn{21}{|c|}{$\begin{array}{c}\text { Burnup, } \\
\text { GWd/t }\end{array}$} \\
\hline $\begin{array}{c}\text { Parameters } \\
\downarrow\end{array}$ & $\theta$ & N & $\nabla$ & 6 & $\infty$ & 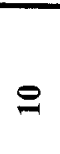 & $\simeq$ & \pm & 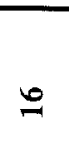 & $\stackrel{\infty}{=}$ & ๙ิ & $\pi$ & $\vec{N}$ & $\stackrel{7}{\circ}$ & $\infty$ & 两 & $\approx$ & 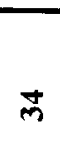 & లా & $\stackrel{\infty}{\infty}$ & F \\
\hline Keff & 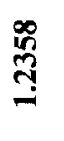 & 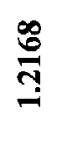 & $\stackrel{5}{9}$ & 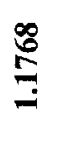 & 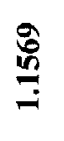 & $\stackrel{\infty}{\stackrel{2}{m}}$ & 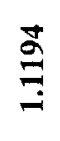 & $\stackrel{\infty}{=}$ & 我 & 荣 & 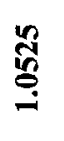 & $\stackrel{\text { : }}{\stackrel{0}{9}}$ & 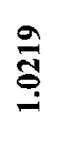 & E્ & స్ & \begin{tabular}{l}
$\infty$ \\
\multirow{2}{\infty}{} \\
0 \\
0
\end{tabular} & 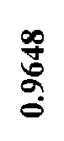 & o & 㐫 & ฏू̃ & d̆ \\
\hline Ko & ঙิ & 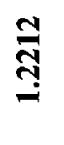 & ঙ্ড & $\stackrel{\Phi}{=}$ & $\stackrel{0}{\stackrel{0}{0}}$ & $\stackrel{n}{\underline{Z}}$ & $\stackrel{\overparen{7}}{\overparen{T}}$ & $\stackrel{\pi}{=}$ & 足 & 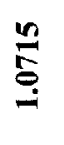 & : & 产 & 导 & 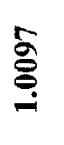 & 贾 & : & $\begin{array}{l}\text { : } \\
\text { : }\end{array}$ & $\begin{array}{c}\text { D. } \\
\text { s. } \\
6\end{array}$ & 京 & స్. & $\frac{10}{9}$ \\
\hline Kkmax-CS & 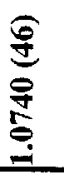 & 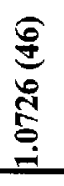 & 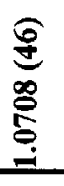 & 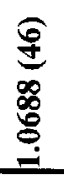 & 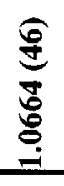 & 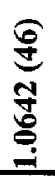 & 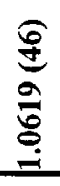 & 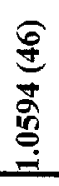 & 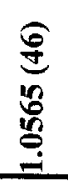 & 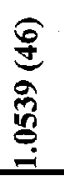 & 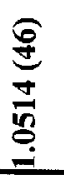 & 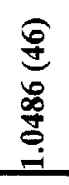 & 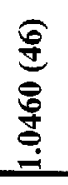 & 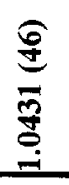 & 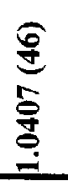 & 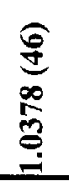 & 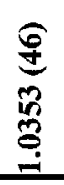 & 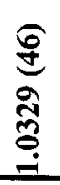 & 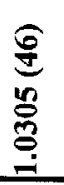 & 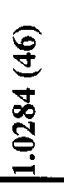 & 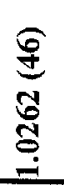 \\
\hline Beff & 产 & 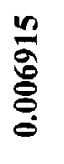 & 疋 & 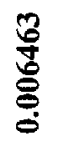 & 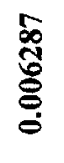 & 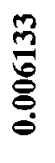 & $\begin{array}{l}\text { S. } \\
\text { : }\end{array}$ & 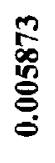 & 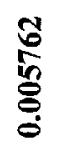 & 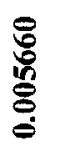 & 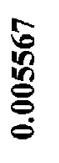 & 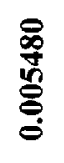 & 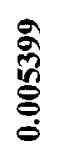 & 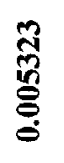 & 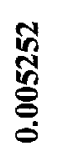 & 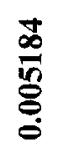 & 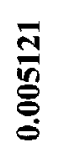 & 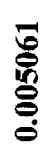 & 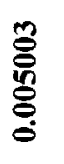 & 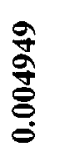 & 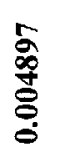 \\
\hline
\end{tabular}


Table 2.9. Parameters Evolution in the Process of Fuel Irradiation. Reference Uranium Assemblage with Boron BPRs

\begin{tabular}{|c|c|c|c|c|c|c|c|c|c|c|c|c|c|c|c|c|c|c|c|c|c|}
\hline $\begin{array}{c}\text { Irradiation } \\
\text { Point } \rightarrow\end{array}$ & \multicolumn{21}{|c|}{$\begin{array}{l}\text { Burnup, } \\
\text { GWd/t }\end{array}$} \\
\hline $\begin{array}{c}\text { Parameters } \\
\downarrow\end{array}$ & $\theta$ & $N$ & 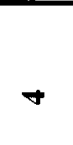 & 6 & $\infty$ & 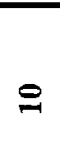 & $\approx$ & \pm & $\stackrel{2}{ }$ & $\stackrel{\infty}{ }$ & 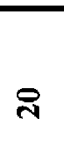 & $\pi$ & $\vec{J}$ & $\stackrel{4}{4}$ & $\stackrel{\infty}{\sim}$ & ల్ల & లి & ग & 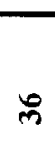 & $\stackrel{\infty}{\infty}$ & $F$ \\
\hline Keff & ث્ণ & $\stackrel{\mathscr{D}}{\stackrel{\infty}{=}}$ & $\stackrel{2}{\Xi}$ & $\stackrel{\circ}{\mathscr{n}}$ & 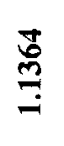 & $\Xi$ & $\stackrel{ \pm}{\underline{E}}$ & 高 & 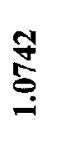 & 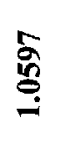 & 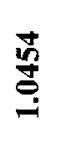 & 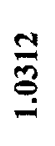 & $\stackrel{5}{5}$ & 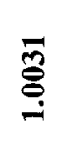 & $\begin{array}{l}\text { ôे } \\
\text { o: } \\
0\end{array}$ & 号 & $\begin{array}{l}\text { चूँ } \\
\text { ¿ }\end{array}$ & के & 菊 & 苛 & ह \\
\hline Ko & $\stackrel{m}{\Xi}$ & $\stackrel{0}{\leftrightarrows}$ & :్రి & : & 产 & 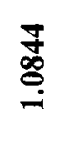 & 总 & $\stackrel{2}{E}$ & : & 惫 & 苞 & 串 & 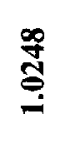 & $\stackrel{0}{\stackrel{0}{9}}$ & : & $\begin{array}{l}\overline{\mathscr{\alpha}} \\
\stackrel{8}{\mathrm{o}} \\
\stackrel{8}{8}\end{array}$ & 蒙 & 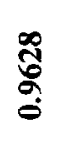 & 宮 & $\begin{array}{l}\infty \\
\vdots \\
0 \\
0\end{array}$ & gू \\
\hline Kkmax-CS & 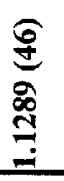 & 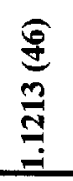 & 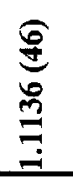 & 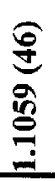 & 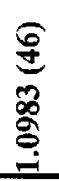 & 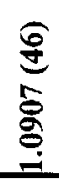 & 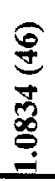 & 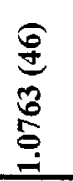 & 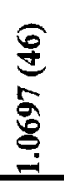 & 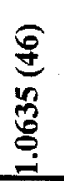 & 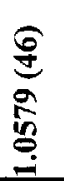 & 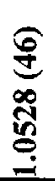 & 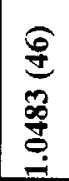 & 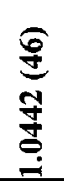 & 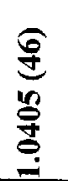 & 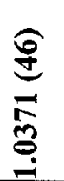 & 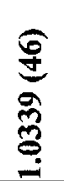 & 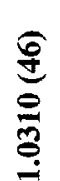 & 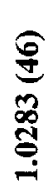 & 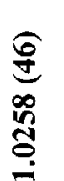 & 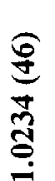 \\
\hline$\beta$ eff & 总 & 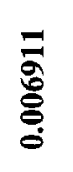 & 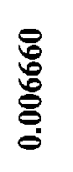 & 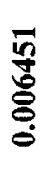 & 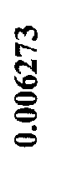 & 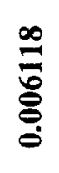 & 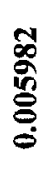 & 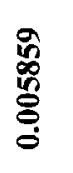 & 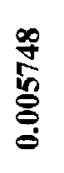 & 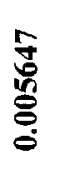 & 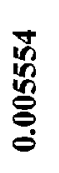 & 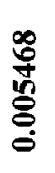 & 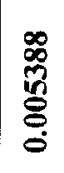 & 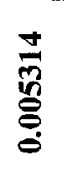 & 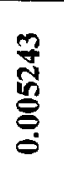 & 点 & 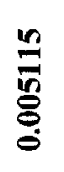 & 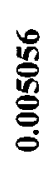 & 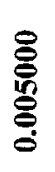 & 旁 & 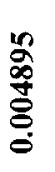 \\
\hline
\end{tabular}


Table 2.10. Parameters Evolution in the Process of Fuel Irradiation. "Island-2" Type MOX LTA

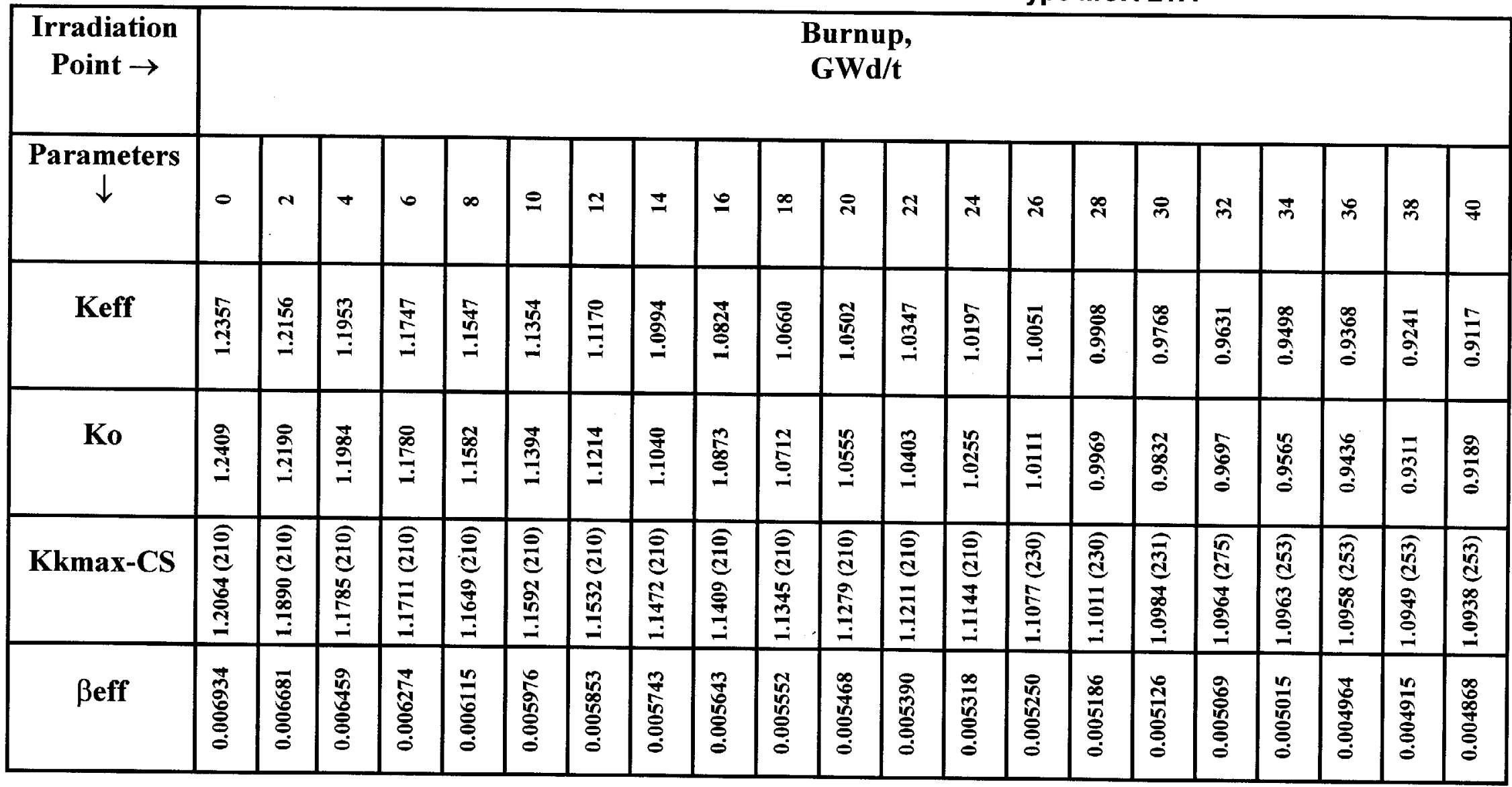


RUSSIAN RESEARCH CENTER KURCHATOV INSTITUTE

Design Studies of "Island" Type MOX Lead Test Assembly (Report for FY99)

Table 3.1. Limiting parameters for VVER-1000

\begin{tabular}{|c|c|c|}
\hline Criterion & Limiting Value & Remarks \\
\hline $\mathrm{Kq}$ & $<=1.35$ & $\begin{array}{c}\text { For nominal power } \\
\mathrm{W}=3000 \mathrm{MW}\end{array}$ \\
\hline $\mathbf{K r}$ & $<=1.60$ & $\begin{array}{c}\text { For nominal power } \\
\mathrm{W}=3000 \mathrm{MW}\end{array}$ \\
\hline$K_{0 \text {-total }}$ & Tabl. 3.2 & $\begin{array}{c}\text { For nominal power } \\
\mathbf{W}=3000 \mathrm{MW}\end{array}$ \\
\hline MTC & $<0$ & \\
\hline MDC & $>0$ & \\
\hline RO stop & $<=-2000 \mathrm{pcm}$ & $\begin{array}{c}t=20^{\circ} \mathrm{C}, \mathrm{Xe}=0, \\
\begin{array}{c}\mathrm{Sm}=\mathrm{Smh}, \mathrm{Cb}=16000 \\
\text { ppm, } \\
\text { all control rods } \\
\text { extracted }\end{array}\end{array}$ \\
\hline RCT & $<220^{\circ} \mathrm{C}$ & \\
\hline$(\mathbf{R O})_{\mathrm{AP}-1}$ & $>5500 \mathrm{pcm}$ & In full power \\
\hline
\end{tabular}

Table 3.2. Limits recommended for total power peaking factor $\mathrm{K}_{\mathrm{o} \text {-total }}$ for VVER-1000

\begin{tabular}{|l|l|l|l|l|l|l|l|l|l|l|}
\hline $\begin{array}{l}\text { Layer } \\
\text { (from bottom } \\
\text { to top) }\end{array}$ & 1 & 2 & 3 & 4 & 5 & 6 & 7 & 8 & 9 & 10 \\
\hline $\mathrm{K}_{\text {o-total }}$ & 2.24 & 2.24 & 2.24 & 2.24 & 2.24 & 2.14 & 1.96 & 1.80 & 1.69 & 1.58 \\
\hline
\end{tabular}


RUSSIAN RESEARCH CENTER KURCHATOV INSTITUTE

Design Studies of "Island" Type MOX Lead Test Assembly (Report for FY99)

Table 3.3. Recommended limiting parameters for VVER-1000 with 3 MOX LTAs.

\begin{tabular}{|c|c|c|}
\hline Criterion & Limiting Value & Remarks \\
\hline $\mathbf{K q}$ & $<=1.35$ & \\
\hline $\mathbf{K r}$ & $<=1.55$ & $\begin{array}{c}\text { In MOX assemblies. For } \\
\text { nominal power } W=3000 \\
\text { MW }\end{array}$ \\
\hline $\mathrm{K}_{\mathrm{o} \text {-total }}$ & Tabl. 3.4 & $\begin{array}{c}\text { In MOX assemblies. For } \\
\text { nominal power } W=3000 \\
\text { MW }\end{array}$ \\
\hline MTC & $<0$ & \\
\hline MDC & $>0$ & \\
\hline RO stop & $<=-2000 \mathrm{pcm}$ & $\begin{array}{c}\mathrm{t}=20^{\circ} \mathrm{C}, \mathrm{Xe}=0, \\
\mathrm{Sm}=\mathrm{Smh}, \mathrm{Cb}=16000 \\
\text { ppm, } \\
\text { all control rods } \\
\text { extracted }\end{array}$ \\
\hline RCT & $<210^{\circ} \mathrm{C}$ & \\
\hline$(\mathbf{R O})_{\mathrm{AP}-1}$ & $>5500 \mathrm{pcm}$ & In full power \\
\hline
\end{tabular}

Table 3.4. Limits recommended for total power peaking factor $\mathrm{K}_{\text {o-total }}$ in MOX assemblies for VVER-1000 with 3 MOX LTAs

\begin{tabular}{|l|l|l|l|l|l|l|l|l|l|l|}
\hline $\begin{array}{l}\text { Layer } \\
\text { (from bottom } \\
\text { to top) }\end{array}$ & 1 & 2 & 3 & 4 & 5 & 6 & 7 & 8 & 9 & 10 \\
\hline $\mathrm{K}_{\mathrm{0} \text {-total }}$ & 2.17 & 2.17 & 2.17 & 2.17 & 2.17 & 2.07 & 1.90 & 1.74 & 1.64 & 1.53 \\
\hline
\end{tabular}


Table 3.5. Evolution of main neutronics parameters in Uranium reference core . Equilibrium cycle

\begin{tabular}{|c|c|c|c|c|c|c|c|c|c|c|c|c|c|c|c|c|c|c|c|c|c|c|c|}
\hline & & & & & & & & & & & & & & & & & & & & \multicolumn{4}{|c|}{$\mathrm{Sim}=60, \mathrm{Xe}=1, \mathrm{Sm}=3$} \\
\hline$\mu$ & $\begin{array}{c}\mathbf{T} \\
\text { EFPD }\end{array}$ & $\begin{array}{c}\mathrm{H}_{\mathrm{reg}} \\
\mathrm{cm}\end{array}$ & ${ }^{t_{\text {entry }}}$ & $\underset{M W}{W}$ & $\begin{array}{l}\mathbf{C b}^{\text {eril }} \\
\text { ppm }\end{array}$ & $\underset{\mathrm{m}^{3} / \mathrm{h}}{\mathbf{G}}$ & $\mathrm{Kq}$ & Nk & $\mathrm{Kq}^{\operatorname{mox}}$ & Nk & $\mathbf{K v}$ & Nk & $\mathbf{N z}$ & $\begin{array}{c}\overline{\mathbf{B}}_{\mathbf{U}} \\
\mathrm{MW} \cdot \\
\mathrm{d} / \mathrm{kg} \\
\end{array}$ & $\begin{array}{c}\overline{\mathbf{B}}_{\text {Mox }} \\
\mathrm{MW} \\
\mathrm{d} / \mathrm{kg}\end{array}$ & $\begin{array}{c}\text { MDC } \\
\text { pcm* } \\
\left(\mathrm{g} / \mathrm{cm}^{3}\right)^{-1}\end{array}$ & $\begin{array}{c}\text { MTC } \\
\text { perne } \\
{ }^{\circ} \mathrm{C}^{-1} \\
\end{array}$ & $\begin{array}{l}\text { DTC } \\
\text { pcm॰ } \\
{ }^{\circ} \mathrm{C}^{-1}\end{array}$ & $\begin{array}{l}\text { DTC } \\
\text { pcme } \\
{ }^{\circ} \mathrm{C}^{-1} \\
\end{array}$ & $\begin{array}{l}\text { DPC } \\
\text { pem: } \\
\mathrm{MW}^{-1}\end{array}$ & $\begin{array}{c}\text { DRo/DCb } \\
\text { pem }^{-1} \\
\mathrm{ppm}^{-1}\end{array}$ & $\begin{array}{l}\beta_{\text {eff. }} \\
\text { pcm }\end{array}$ & $\begin{array}{r}\mathrm{l}_{\mathrm{lm}} \\
.10^{5} \\
\sec \\
\end{array}$ \\
\hline 1 & 0.0 & 283.2 & 287.0 & 3000 & 5657 & 84000 & 1.31 & 19 & 0.00 & 0 & 1.61 & 19 & 4 & 14.14 & 0.00 & 12293 & -25.94 & -2.96 & -2.46 & -0.29 & -1.55 & 650 & 2.24 \\
\hline 2 & 20.0 & 283.2 & 287.0 & 3000 & 5318 & 84000 & 1.31 & 19 & 0.00 & 0 & 1.58 & 19 & 4 & 15.00 & 0.00 & 12894 & -26.94 & -2.96 & -2.47 & -0.29 & -1.55 & 639 & 2.24 \\
\hline 3 & 40.0 & 283.2 & 287.0 & 3000 & 4899 & 84000 & 1.31 & 19 & 0.00 & 0 & 1.56 & 19 & 4 & 15.85 & 0.00 & 14000 & -29.20 & -2.94 & -2.48 & -0.29 & -1.56 & 630 & 2.25 \\
\hline 4 & 60.0 & 283.2 & 287.0 & 3000 & 4473 & 84000 & 1.31 & 19 & 0.00 & 0 & 1.53 & 19 & 3 & 16.70 & 0.00 & 15191 & -31.69 & -2.93 & -2.50 & -0.29 & -1.57 & 622 & 2.27 \\
\hline 5 & 80.0 & 283.2 & 287.0 & 3000 & 4047 & 84000 & 1.31 & 19 & 0.00 & 0 & 1.52 & 19 & 3 & 17.55 & 0.00 & 16400 & -34.24 & -2.93 & -2.52 & -0.29 & -1.58 & 613 & 2.29 \\
\hline 6 & 100.0 & 283.2 & 287.0 & 3000 & 3631 & 84000 & 1.31 & 19 & 0.00 & 0 & 1.51 & 19 & 3 & 18.41 & 0.00 & 17590 & -36.77 & -2.94 & -2.55 & -0.29 & -1.59 & 606 & 2.31 \\
\hline 7 & 120.0 & 283.2 & 287.0 & 3000 & 3215 & 84000 & 1.30 & 19 & 0.00 & 0 & 1.50 & 19 & 3 & 19.26 & 0.00 & 18775 & -39.30 & -2.96 & -2.58 & -0.29 & -1.60 & 598 & 2.33 \\
\hline 8 & 140.0 & 283.2 & 287.0 & 3000 & 2813 & 84000 & 1.30 & 19 & 0.00 & 0 & 1.49 & 19 & 3 & 20.11 & 0.00 & 19928 & -41.77 & -2.97 & -2.60 & -0.29 & -1.62 & 591 & 2.35 \\
\hline 9 & 160.0 & 283.2 & 287.0 & 3000 & 2411 & 84000 & 1.30 & 19 & 0.00 & 0 & 1.48 & 19 & 3 & 20.96 & 0.00 & 21077 & -44.25 & -2.99 & -2.63 & -0.29 & -1.63 & 585 & 2.37 \\
\hline 10 & 180.0 & 283.2 & 287.0 & 3000 & 2023 & 84000 & 1.30 & 19 & 0.00 & 0 & 1.47 & 19 & 2 & 21.82 & 0.00 & 22203 & -46.69 & -3.02 & -2.66 & -0.29 & -1.64 & 578 & 2.40 \\
\hline 11 & 200.0 & 283.2 & 287.0 & 3000 & 1634 & 84000 & 1.30 & 19 & 0.00 & 0 & 1.47 & 19 & 2 & 22.67 & 0.00 & 23333 & -49.16 & -3.04 & -2.69 & -0.29 & -1.66 & 573 & 2.42 \\
\hline 12 & 220.0 & 283.2 & 287.0 & 3000 & 1254 & 84000 & 1.29 & 19 & 0.00 & 0 & 1.47 & 19 & 2 & 23.52 & 0.00 & 24457 & -51.62 & -3.06 & -2.71 & -0.29 & -1.67 & 567 & 2.45 \\
\hline 13 & 240.0 & 283.2 & 287.0 & 3000 & 874 & 84000 & 1.29 & 19 & 0.00 & 0 & 1.47 & 19 & 2 & 24.37 & 0.00 & 25592 & -54.13 & -3.08 & -2.74 & -0.30 & -1.68 & 562 & 2.48 \\
\hline 14 & 260.0 & 283.2 & 287.0 & 3000 & 500 & 84000 & 1.29 & 19 & 0.00 & 0 & 1.46 & 19 & 2 & 25.23 & 0.00 & 26727 & -56.64 & -3.09 & -2.76 & -0.30 & -1.70 & 557 & 2.51 \\
\hline 15 & 280.0 & 283.2 & 287.0 & 3000 & 127 & 84000 & 1.28 & 19 & 0.00 & 0 & 1.46 & 19 & 2 & 26.08 & 0.00 & 27869 & -59.18 & -3.11 & -2.79 & -0.30 & -1.71 & 552 & 2.54 \\
\hline 16 & 286.9 & 283.2 & 287.0 & 3000 & 0 & 84000 & 1.28 & 19 & 0.00 & 0 & 1.45 & 19 & 2 & 26.37 & 0.00 & 28260 & -60.05 & -3.12 & -2.80 & -0.30 & -1.72 & 551 & 2.55 \\
\hline
\end{tabular}


Table 3.6. Main neutronics parameters in zero power states. Reference Uranium Core Equilibrium Cycle

\begin{tabular}{|c|c|c|c|c|c|c|c|c|c|c|c|c|c|}
\hline $\mathbf{T}$ & $\begin{array}{l}\text { RO } \\
\text { pcm }\end{array}$ & $\begin{array}{c}\text { Cb } \\
\text { ppm }\end{array}$ & Bank 10 & $\begin{array}{c}\text { Other } \\
\text { banks } \downarrow \uparrow\end{array}$ & $\mathbf{X e}$ & Sm & $\underset{{ }^{\circ} \mathrm{C}}{\text { Tmod }}$ & $\begin{array}{c}\mathrm{MTC} \\
\mathrm{pcm} /{ }^{\circ} \mathrm{C}\end{array}$ & $\begin{array}{c}\mathrm{MDC} \\
\mathrm{pcm} / \mathrm{g} / \mathrm{cc}\end{array}$ & $\begin{array}{c}\text { DTC } \\
\mathrm{pcm} /{ }^{\circ} \mathrm{C}\end{array}$ & $\begin{array}{l}\text { DRO/DCB } \\
\mathrm{pem} / \mathrm{ppm}\end{array}$ & $\begin{array}{c}\lambda \mathrm{m} \\
* 10^{5} \mathrm{~s}\end{array}$ & $\begin{array}{r}\text { ßeff } \\
{ }^{*} 100\end{array}$ \\
\hline BOC & 0 & 8860 & $100 \% \uparrow$ & $100 \% \uparrow$ & 0 & Smh & 280 & -1.23 & 2210 & -2.93 & -1.49 & 2.10 & 0.65 \\
\hline EOC & 0 & 2000 & $100 \% \uparrow$ & $100 \% \uparrow$ & eq & Sm eq & 280 & -27.52 & 18730 & -3.31 & -1.76 & 2.44 & 0.57 \\
\hline BOC & $\begin{array}{c}-14237 \\
\left(\mathrm{RO}_{\text {STOP }}\right) \\
\end{array}$ & 16000 & $100 \% \uparrow$ & $100 \% \uparrow$ & 0 & $\overline{S m h}$ & 20 & & & & & & \\
\hline
\end{tabular}


Table 3.7. Evolution of main neutronics parameters. First cycle with 3 MOX LTAs of "Island-2" type

\begin{tabular}{|c|c|c|c|c|c|c|c|c|c|c|c|c|c|c|c|c|c|c|c|c|c|c|c|}
\hline \multirow[b]{2}{*}{$\boldsymbol{\mu}$} & \multirow[b]{2}{*}{$\begin{array}{c}\mathbf{T} \\
\text { EFPD }\end{array}$} & \multirow[b]{2}{*}{$\begin{array}{l}\mathrm{H}_{\mathrm{rem}} \\
\mathrm{cm}\end{array}$} & \multirow[b]{2}{*}{${ }^{t}$ entry } & \multirow[b]{2}{*}{$\underset{M W}{W}$} & \multirow[b]{2}{*}{$\begin{array}{l}\mathrm{Cb}^{\text {orit. }} \\
\mathrm{ppm}\end{array}$} & \multirow[b]{2}{*}{$\underset{\mathrm{m}^{3} / \mathrm{h}}{\mathbf{G}}$} & \multirow[b]{2}{*}{$\mathrm{Kq}$} & \multirow[b]{2}{*}{ Nk } & \multirow[b]{2}{*}{$\mathrm{Kq}^{\mathrm{MOx}}$} & \multirow[b]{2}{*}{ Nk } & \multirow[b]{2}{*}{$\mathbf{K v}$} & \multirow[b]{2}{*}{ Nk } & \multirow[b]{2}{*}{$\mathbf{N z}$} & \multirow[b]{2}{*}{$\begin{array}{c}\overline{\mathrm{B}}_{\mathrm{U}} \\
\mathrm{MW} \bullet \\
\mathrm{d} / \mathrm{kg} \\
\end{array}$} & \multirow[b]{2}{*}{$\begin{array}{c}\bar{B}_{\text {Mox }} \\
M W \cdot \\
d / \mathrm{kg} \\
\end{array}$} & \multirow[b]{2}{*}{$\begin{array}{c}\text { MDC } \\
\text { pcm } \\
\left(\mathrm{g} / \mathrm{cm}^{3}\right)^{-1}\end{array}$} & \multirow[b]{2}{*}{$\begin{array}{c}\text { MTC } \\
\text { pem• } \\
{ }^{\circ} \mathrm{C}^{-1} \\
\end{array}$} & \multirow[b]{2}{*}{$\begin{array}{c}\text { DTC } \\
\text { pem* } \\
{ }^{\circ} \mathrm{C}^{-1} \\
\end{array}$} & \multirow[b]{2}{*}{$\begin{array}{l}\text { DTC } \\
\text { pcm: } \\
{ }^{\circ} \mathrm{C}^{-1} \\
\end{array}$} & \multicolumn{4}{|c|}{$\mathrm{Sim}=360, \mathrm{Xe}=1, \mathrm{Sm}=3$} \\
\hline & & & & & & & & & & & & & & & & & & & & $\begin{array}{l}\text { DPC } \\
\text { pcm. } \\
\mathrm{MW}^{-1} \\
\end{array}$ & $\begin{array}{c}\text { DRo/DCb } \\
\text { pcm: } \\
\text { ppm }^{-1}\end{array}$ & $\begin{array}{l}\boldsymbol{\beta}_{\text {ef. }} \\
\text { pem }\end{array}$ & $\begin{array}{l}\lim _{\lim _{10}} \\
\sec \\
\end{array}$ \\
\hline 1 & 0.0 & 283.2 & 287.0 & 3000 & 5773 & 84000 & 1.32 & 38 & 1.01 & 8 & 1.61 & 38 & 4 & 14.26 & 0.00 & 11944 & -24.84 & -2.88 & -2.49 & -0.28 & -1.57 & 647 & 2.25 \\
\hline 2 & 20.0 & 283.2 & 287.0 & 3000 & 5435 & 84000 & 1.27 & 38 & 0.97 & 8 & 1.52 & 38 & 4 & 15.12 & 0.86 & 12535 & -25.79 & -2.88 & -2.50 & -0.28 & -1.57 & 636 & 2.25 \\
\hline 3 & 40.0 & 283.2 & 287.0 & 3000 & 5014 & 84000 & 1.26 & 38 & 0.97 & 8 & 1.49 & 38 & 4 & 15.97 & 1.69 & 13669 & -28.14 & -2.87 & -2.51 & -0.28 & -1.57 & 628 & 2.27 \\
\hline 4 & 60.0 & 283.2 & 287.0 & 3000 & 4586 & 84000 & 1.26 & 117 & 0.97 & 8 & 1.47 & 47 & 3 & 16.82 & 2.52 & 14879 & -30.69 & -2.87 & -2.53 & -0.28 & -1.59 & 620 & 2.28 \\
\hline 5 & 80.0 & 283.2 & 287.0 & 3000 & 4158 & 84000 & 1.26 & 72 & 0.96 & 150 & 1.45 & 72 & 3 & 17.67 & 3.34 & 16104 & -33.29 & -2.88 & -2.55 & -0.28 & -1.60 & 612 & 2.30 \\
\hline 6 & 100.0 & 283.2 & 287.0 & 3000 & 3737 & 84000 & 1.26 & 72 & 0.96 & 150 & 1.44 & 132 & 3 & 18.53 & 4.16 & 17315 & -35.88 & -2.89 & -2.58 & -0.28 & -1.61 & 604 & 2.32 \\
\hline 7 & 120.0 & 283.2 & 287.0 & 3000 & 3316 & 84000 & 1.26 & 132 & 0.96 & 88 & 1.44 & 132 & 3 & 19.38 & 4.98 & 18523 & -38.47 & -2.90 & -2.60 & -0.28 & -1.62 & 597 & 2.34 \\
\hline 8 & 140.0 & 283.2 & 287.0 & 3000 & 2905 & 84000 & 1.26 & 132 & 0.96 & 88 & 1.44 & 132 & 3 & 20.23 & 5.80 & 19708 & -41.02 & -2.92 & -2.62 & -0.28 & -1.63 & 590 & 2.36 \\
\hline 9 & 160.0 & 283.2 & 287.0 & 3000 & 2493 & 84000 & 1.26 & 132 & 0.96 & 88 & 1.43 & 124 & 3 & 21.09 & 6.62 & 20889 & -43.58 & -2.94 & -2.65 & -0.28 & -1.64 & 584 & 2.39 \\
\hline 10 & 180.0 & 283.2 & 287.0 & 3000 & 2093 & 84000 & 1.27 & 132 & 0.96 & 88 & 1.44 & 124 & 2 & 21.94 & 7.44 & 22050 & -46.11 & -2.96 & -2.67 & -0.29 & -1.66 & 578 & 2.41 \\
\hline 11 & 200.0 & 283.2 & 287.0 & 3000 & 1694 & 84000 & 1.27 & 124 & 0.96 & 88 & 1.44 & 124 & 2 & 22.79 & 8.25 & 23214 & -48.66 & -2.98 & -2.70 & -0.29 & -1.67 & 572 & 2.44 \\
\hline 12 & 220.0 & 283.2 & 287.0 & 3000 & 1301 & 84000 & 1.27 & 124 & 0.96 & 88 & 1.45 & 124 & 2 & 23.65 & 9.07 & 24372 & -51.19 & -3.00 & -2.72 & -0.29 & -1.68 & 566 & 2.47 \\
\hline 13 & 240.0 & 283.2 & 287.0 & 3000 & 909 & 84000 & 1.27 & 124 & 0.96 & 88 & 1.45 & 124 & 2 & 24.50 & 9.88 & 25537 & -53.76 & -3.02 & -2.74 & -0.29 & -1.70 & 561 & 2.49 \\
\hline 14 & 260.0 & 283.2 & 287.0 & 3000 & 524 & 84000 & 1.27 & 124 & 0.96 & 88 & 1.45 & 124 & 2 & 25.35 & 10.70 & 26697 & -56.33 & -3.04 & -2.76 & -0.29 & -1.71 & 556 & 2.52 \\
\hline 15 & 280.0 & 283.2 & 287.0 & 3000 & 139 & 84000 & 1.27 & 124 & 0.96 & 88 & 1.45 & 124 & 2 & 26.21 & 11.51 & 27861 & -58.91 & -3.05 & -2.79 & -0.29 & -1.73 & 552 & 2.55 \\
\hline 16 & 287.4 & 283.2 & 287.0 & 3000 & 0 & 84000 & 1.27 & 124 & 0.96 & 88 & 1.45 & 124 & 2 & 26.52 & 11.81 & 28287 & -59.87 & -3.06 & -2.79 & -0.29 & -1.73 & 550 & 2.57 \\
\hline
\end{tabular}


Table 3.8. Main neutronics parameters in zero power states. First cycle with 3 MOX LTAs of "Island-2" type

\begin{tabular}{|c|c|c|c|c|c|c|c|c|c|c|c|c|c|}
\hline $\mathbf{T}$ & $\begin{array}{l}\text { RO } \\
\text { pem }\end{array}$ & $\begin{array}{c}\mathbf{C b} \\
\mathbf{p p m} \\
\end{array}$ & Bank 10 & $\begin{array}{c}\text { Other } \\
\text { banks } \downarrow \uparrow\end{array}$ & $\mathbf{X e}$ & Sm & $\underset{{ }^{\circ} \mathrm{C}}{\text { Tmod }}$ & $\begin{array}{c}\text { MTC } \\
\mathrm{pcm} /{ }^{\circ} \mathrm{C}\end{array}$ & $\begin{array}{c}\mathrm{MDC} \\
\mathrm{pcm} / \mathrm{g} / \mathrm{cc}\end{array}$ & $\begin{array}{c}\text { DTC } \\
\mathrm{pem} /{ }^{\circ} \mathrm{C}\end{array}$ & $\begin{array}{l}\text { DRO/DCB } \\
\mathrm{pcm} / \mathrm{ppm}\end{array}$ & $\begin{array}{r}\lambda \mathrm{m} \\
* 10^{5} \mathrm{~s} \\
\end{array}$ & $\begin{array}{r}\beta \text { Beff } \\
* 100 \\
\end{array}$ \\
\hline BOC & $\mathbf{0}$ & 88900 & $100 \% \uparrow$ & $100 \% \uparrow$ & 0 & Smh & 280 & -0.75 & 2090 & -2.96 & -1.50 & 2.11 & 0.65 \\
\hline EOC & 0 & 1960 & $100 \% \uparrow$ & $100 \% \uparrow$ & eq & Sm eq & 280 & -27.64 & 18840 & -3.31 & -1.78 & 2.46 & 0.56 \\
\hline$\overline{B O C}$ & $\begin{array}{c}-14338 \\
\left(\text { RO }_{\text {STOP }}\right) \\
\end{array}$ & 16000 & $100 \% \uparrow$ & $100 \% \uparrow$ & 0 & Smh & 20 & & & & & & \\
\hline
\end{tabular}


Table 3.9. Evolution of main neutronics parameters. Second cycle with 3 MOX LTAs of "Island-2" type

\begin{tabular}{|c|c|c|c|c|c|c|c|c|c|c|c|c|c|c|c|c|c|c|c|c|c|c|c|}
\hline \multirow[b]{2}{*}{$N$} & \multirow[b]{2}{*}{$\stackrel{T}{\text { EFPD }}$} & \multirow[b]{2}{*}{$\begin{array}{c}\mathrm{H}_{\mathrm{rat}} \\
\mathrm{cm}\end{array}$} & \multirow[b]{2}{*}{${ }^{t_{\operatorname{mon}} \mathrm{C} y}$} & \multirow[b]{2}{*}{$\underset{M W}{W}$} & \multirow[b]{2}{*}{$\begin{array}{c}\mathrm{Cb}^{\text {aril }} \\
\text { ppm }\end{array}$} & \multirow[b]{2}{*}{$\underset{\mathrm{m}^{3} / \mathrm{h}}{\mathbf{G}}$} & \multirow[b]{2}{*}{$\mathrm{Kq}$} & \multirow[b]{2}{*}{ Nk } & \multirow[b]{2}{*}{$\mathrm{Kq}^{\mathrm{Mox}}$} & \multirow[b]{2}{*}{ Nk } & \multirow[b]{2}{*}{ Kv } & \multirow[b]{2}{*}{ Nk } & \multirow[b]{2}{*}{$\mathbf{N z}$} & \multirow[b]{2}{*}{$\begin{array}{c}\overline{\mathbf{B}}_{\mathbf{u}} \\
\mathrm{MW} \\
\mathrm{d} / \mathbf{k g} \\
\end{array}$} & \multirow[b]{2}{*}{$\begin{array}{c}\overline{\mathbf{B}}_{\text {Mox }} \\
\text { MW• } \\
\mathrm{d} / \mathrm{kg} \\
\end{array}$} & \multirow[b]{2}{*}{$\begin{array}{c}\mathrm{MDC} \\
\mathrm{pcm} \cdot \\
\left(\mathrm{g} / \mathrm{cm}^{3}\right)^{-1}\end{array}$} & \multirow[b]{2}{*}{$\begin{array}{c}\text { MTC } \\
\text { pem } \\
{ }^{\circ} \mathrm{C}^{-1}\end{array}$} & \multirow[b]{2}{*}{$\begin{array}{c}\text { DTC } \\
\text { pcm } \\
{ }^{\circ} \mathrm{C}^{-1}\end{array}$} & \multirow[b]{2}{*}{$\begin{array}{c}\text { DTC } \\
\text { pcm } \\
{ }^{\circ} \mathrm{C}^{-1} \\
\end{array}$} & \multicolumn{4}{|c|}{ Sim $=360, X e=1, S m=3$} \\
\hline & & & & & & & & & & & & & & & & & & & & $\begin{array}{l}\mathrm{DPC} \\
\mathrm{pcm} \\
\mathrm{MW}\end{array}$ & $\begin{array}{c}\mathrm{DRo} / \mathrm{DCb} \\
\mathrm{pcm} \\
\mathrm{ppm}^{-1}\end{array}$ & $\begin{array}{l}\boldsymbol{\beta}_{\text {ef. }} \\
\text { pcm }\end{array}$ & $\begin{array}{l}\mathrm{l}_{\mathrm{tm}} \\
.10^{5} \\
\sec \\
\end{array}$ \\
\hline 1 & 0.0 & 283.2 & 287.0 & 3000 & 5658 & 84000 & 1.34 & 153 & 1.23 & 141 & 1.66 & 153 & 4 & 13.86 & 11.81 & 12366 & -25.86 & -2.87 & -2.47 & -0.28 & -1.57 & 647 & 2.25 \\
\hline 2 & 20.0 & 283.2 & 287.0 & 3000 & 5322 & 84000 & 1.28 & 153 & 1.23 & 141 & 1.55 & 153 & 4 & 14.70 & 12.86 & 12989 & -26.89 & -2.88 & -2.49 & -0.28 & -1.57 & 636 & 2.25 \\
\hline 3 & 40.0 & 283.2 & 287.0 & 3000 & 4905 & 84000 & 1.28 & 153 & 1.22 & 141 & 1.52 & 153 & 4 & 15.55 & 13.91 & 14105 & -29.20 & -2.87 & -2.51 & -0.28 & -1.57 & 628 & 2.27 \\
\hline 4 & 60.0 & 283.2 & 287.0 & 3000 & 4487 & 84000 & 1.27 & 153 & 1.21 & 141 & 1.49 & 153 & 3 & 16.40 & 14.95 & 15283 & -31.67 & -2.87 & -2.53 & -0.28 & -1.58 & 619 & 2.28 \\
\hline 5 & 80.0 & 283.2 & 287.0 & 3000 & 4061 & 84000 & 1.27 & 153 & 1.20 & 141 & 1.47 & 153 & 3 & 17.25 & 15.98 & 16492 & -34.24 & -2.87 & -2.55 & -0.28 & -1.59 & 612 & 2.30 \\
\hline 6 & 100.0 & 283.2 & 287.0 & 3000 & 3641 & 84000 & 1.26 & 153 & 1.20 & 18 & 1.45 & 47 & 3 & 18.10 & 17.00 & 17687 & -36.78 & -2.88 & -2.57 & -0.28 & -1.61 & 604 & 2.32 \\
\hline 7 & 120.0 & 283.2 & 287.0 & 3000 & 3221 & 84000 & 1.25 & 153 & 1.19 & 18 & 1.43 & 47 & 3 & 18.95 & 18.03 & 18878 & -39.34 & -2 & -2.60 & -0.28 & -1.62 & 597 & 2.34 \\
\hline 8 & 140.0 & 283.2 & 287.0 & 3000 & 2817 & 84000 & 1.24 & 47 & 1.19 & 18 & 1.41 & 47 & 3 & 19.80 & 19.04 & 20037 & -41.83 & -2 & -2.62 & -0.28 & -1.63 & 590 & 2.36 \\
\hline 9 & 160.0 & 283.2 & 287.0 & 3000 & 2413 & 84000 & 1.24 & 110 & 1.18 & 18 & 1.40 & 110 & 3 & 20.65 & 20.05 & 21192 & -44.32 & -2.93 & -2.65 & -0.28 & -1.64 & 584 & 2.38 \\
\hline 10 & 180.0 & 283.2 & 287.0 & 3000 & 2016 & 84000 & 1.24 & 110 & 1.18 & 18 & 1.40 & 110 & 2 & 21.50 & 21.06 & 22334 & -46.80 & -2.95 & -2.67 & -0.29 & -1.65 & 578 & 2.41 \\
\hline 11 & 200.0 & 283.2 & 287.0 & 3000 & 1620 & 84000 & 1.25 & 110 & 1.17 & 18 & 1.41 & 110 & 2 & 22.35 & 22.07 & 23479 & -49.29 & -2.97 & -2.70 & -0.29 & -1.67 & 572 & 2.44 \\
\hline 12 & 220.0 & 283.2 & 287.0 & 3000 & 1234 & 84000 & 1.25 & 110 & 1.17 & 18 & 1.42 & 110 & 2 & 23.20 & 23.06 & 24610 & -51.76 & -2.99 & -2.72 & -0.29 & -1.68 & 566 & 2.46 \\
\hline 13 & 240.0 & 283.2 & 287.0 & 3000 & 849 & 84000 & 1.25 & 110 & 1.17 & 18 & 1.42 & 110 & 2 & 24.05 & 24.06 & 25749 & -54.26 & -3.01 & -2.74 & -0.29 & -1.69 & 561 & 2.49 \\
\hline 14 & 260.0 & 283.2 & 287.0 & 3000 & 469 & 84000 & 1.25 & 110 & 1.16 & 18 & 1.42 & 110 & 2 & 24.90 & 25.05 & 26885 & -56.76 & -3.03 & -2.76 & -0.29 & -1.71 & 556 & 2.52 \\
\hline 15 & 280.0 & 283.2 & 287.0 & 3000 & 90 & 84000 & 1.25 & 110 & 1.16 & 18 & 1.42 & 110 & 2 & 25.75 & 26.05 & 28028 & -59.29 & -3.04 & -2.79 & -0.29 & -1.72 & 552 & 2.55 \\
\hline 16 & 284.8 & 283.2 & 287.0 & 3000 & 0 & 84000 & 1.25 & 110 & 1.16 & 18 & 1.42 & 56 & 2 & 25.95 & 26.28 & 28301 & -59.90 & -3.05 & -2.79 & -0.29 & -1.73 & 551 & 2.56 \\
\hline
\end{tabular}


RUSSIAN RESEARCH CENTER KURCHATOV INSTITUTE

Design Studies of "Island" Type MOX Lead Test Assembly (Report for FY99)

Table 3.10. Main neutronics parameters in zero power states. Second cycle with 3 MOX LTAs of "Island-2" type

\begin{tabular}{|c|c|c|c|c|c|c|c|c|c|c|c|c|c|}
\hline $\mathbf{T}$ & $\begin{array}{l}\text { RO } \\
\text { pcm }\end{array}$ & $\begin{array}{c}\mathrm{Cb} \\
\mathbf{p p m}\end{array}$ & Bank 10 & $\begin{array}{c}\text { Other } \\
\text { banks } \downarrow \uparrow\end{array}$ & $\mathbf{X e}$ & Sm & $\underset{{ }^{\circ} \mathrm{C}}{\text { Tmod }}$ & $\begin{array}{c}\text { MTC } \\
\text { pem/ } /{ }^{\circ} \mathrm{C}\end{array}$ & $\begin{array}{c}\mathrm{MDC} \\
\mathrm{pem} / \mathrm{g} / \mathrm{cc}\end{array}$ & $\begin{array}{c}\text { DTC } \\
\mathrm{pem} /{ }^{\circ} \mathrm{C} \\
\end{array}$ & $\begin{array}{l}\text { DRO/DCB } \\
\mathrm{pcm} / \mathrm{ppm}\end{array}$ & $\begin{array}{r}\lambda \mathrm{m} \\
* 10^{5} \\
\end{array}$ & $\begin{array}{r}\beta \text { eff } \\
{ }^{*} 100 \\
\end{array}$ \\
\hline BOC & 0 & 9330 & $100 \% \uparrow$ & $100 \% \uparrow$ & 0 & Smh & 280 & -1.61 & 2540 & -2.96 & -1.51 & 2.12 & 0.65 \\
\hline EOC & 0 & 2090 & $100 \% \uparrow$ & $100 \% \uparrow$ & eq & Sm eq & 280 & -27.85 & 18940 & -3.31 & -1.77 & 2.45 & 0.56 \\
\hline BOC & $\begin{array}{c}-14463 \\
\left(\mathrm{RO}_{\text {STOP }}\right) \\
\end{array}$ & 16000 & $100 \% \uparrow$ & $100 \% \uparrow$ & 0 & Smh & 20 & & & & & & \\
\hline
\end{tabular}


RUSSIAN RESEARCH CENTER KURCHATOV INSTITUTE

Design Studies of "Island" Type MOX Lead Test Assembly (Report for FY99)

Table 3.11. Evolution of main neutronics parameters. 3-d cycle with 3 MOX LTAs of "Island-2" type

\begin{tabular}{|c|c|c|c|c|c|c|c|c|c|c|c|c|c|c|c|c|c|c|c|c|c|c|c|}
\hline & & & & & & & & & & & & & & & & & & & & \multicolumn{4}{|c|}{$\mathrm{Sim}=360, \mathrm{Xe}=1, \mathrm{Sm}=\mathbf{3}$} \\
\hline$\mu$ & $\begin{array}{c}\mathrm{T} \\
\text { EFPD }\end{array}$ & $\begin{array}{l}\mathrm{H}_{\mathrm{rm}} \\
\mathrm{cm}\end{array}$ & $\begin{array}{c}t_{\text {entry }} \\
{ }^{\circ} \mathrm{C}\end{array}$ & $\underset{M W}{W}$ & $\begin{array}{l}\mathrm{Cb}^{\mathrm{ert}} \\
\mathrm{ppm}\end{array}$ & $\begin{array}{c}\mathrm{G} \\
\mathrm{m}^{3} / \mathrm{h}\end{array}$ & $\mathbf{K q}$ & Nk & $\mathrm{Kq}^{\operatorname{MOx}}$ & Nk & Kv & Nk & $\mathrm{Nz}$ & $\begin{array}{c}\overline{\mathbf{B}}_{\mathrm{u}} \\
\mathrm{MW} \\
\mathrm{d} / \mathrm{kg} \\
\end{array}$ & $\begin{array}{c}\overline{\mathrm{B}}_{\text {wox }} \\
M W \cdot \\
\mathrm{d} / \mathrm{kg} \\
\end{array}$ & $\begin{array}{c}\text { MDC } \\
\text { pcme } \\
\left(\mathrm{g} / \mathrm{cm}^{3}\right)^{-1} \\
\end{array}$ & $\begin{array}{l}\text { MTC } \\
\text { pcm. } \\
{ }^{\circ} \mathrm{C}^{-1}\end{array}$ & $\begin{array}{l}\text { DTC } \\
\text { pcm. } \\
{ }^{\circ} \mathrm{C}^{-1}\end{array}$ & $\begin{array}{c}\text { DTC } \\
\text { pcm. } \\
{ }^{\circ} \mathrm{C}^{-1} \\
\end{array}$ & $\begin{array}{c}\text { DPC } \\
\text { pcm* } \\
\text { MW }^{-1} \\
\end{array}$ & $\begin{array}{c}\mathrm{DRo} / \mathrm{DCb} \\
\mathrm{pcm} \\
\mathrm{ppm}^{-1} \\
\end{array}$ & $\begin{array}{c}\boldsymbol{\beta}_{\mathrm{ed}} \\
\mathrm{pcm}\end{array}$ & $\begin{array}{r}I_{\mathrm{lm}_{\mathrm{m}}} \\
\cdot 10^{5} \\
\text { sec } \\
\end{array}$ \\
\hline 1 & 0.0 & 283.2 & 287.0 & 3000 & 5790 & 84000 & 1.33 & 126 & 1.03 & 111 & 1.64 & 126 & 4 & 13.41 & 26.28 & 11833 & -24.63 & -2.89 & -2.49 & -0.28 & -1.56 & 648 & 2.24 \\
\hline 2 & 20.0 & 283.2 & 287.0 & 3000 & 5455 & 84000 & 1.28 & 126 & 1.06 & 111 & 1.54 & 126 & 4 & 14.26 & 27.16 & 12483 & -25.71 & -2.89 & -2.50 & -0.28 & -1.56 & 638 & 2.25 \\
\hline 3 & 40.0 & 283.2 & 287.0 & 3000 & 5039 & 84000 & 1.27 & 11 & 1.05 & 111 & 1.51 & 126 & 4 & 15.11 & 28.06 & 13606 & -28.04 & -2.89 & -2 & -0.28 & -1.57 & 629 & 2.26 \\
\hline 4 & 60.0 & 283.2 & 287.0 & 3000 & 4616 & 84000 & 1.27 & 124 & 1.05 & 111 & 1.48 & 124 & 4 & 15.97 & 28.96 & 14802 & -30.56 & -2.88 & -2 & -0.28 & -1.58 & 621 & 2.28 \\
\hline 5 & 80.0 & 283.2 & 287.0 & 3000 & 4193 & 84000 & 1.27 & 124 & 1.05 & 111 & 1.47 & 124 & 3 & 16.82 & 29.85 & 16012 & -33.13 & -2.89 & -2.56 & -0.28 & -1.59 & 613 & 2.29 \\
\hline 6 & 100.0 & 283.2 & 287.0 & 3000 & 3770 & 84000 & 1.27 & 124 & 1.04 & 111 & 1.46 & 124 & 3 & 17.67 & 30.74 & 17220 & -35.70 & -2.89 & -2.58 & -0.28 & -1.60 & 606 & 2.31 \\
\hline 7 & 120.0 & 283.2 & 287.0 & 3000 & 3361 & 84000 & 1.27 & 124 & 1.04 & 111 & 1.45 & 124 & 3 & 18.52 & 31.63 & 18399 & -38 & -2 & -2.60 & -0.28 & -1.61 & 599 & 2.33 \\
\hline 8 & 140.0 & 283.2 & 287.0 & 3000 & 2952 & 84000 & 1.27 & 124 & 1.04 & 111 & 1.44 & 124 & 3 & 19.37 & 32.52 & 19573 & -40.75 & -2.92 & -2 & -0.28 & -1.63 & 592 & 2.36 \\
\hline 9 & 160.0 & 283.2 & 287.0 & 3000 & 2543 & 84000 & 1.26 & 124 & 1.05 & 111 & 1.44 & 124 & 3 & 20.23 & 33.41 & 20743 & & -2 & -2 & -0.28 & -1.64 & 585 & 2.38 \\
\hline 10 & 180.0 & 283.2 & 287.0 & 3000 & 2147 & 84000 & 1.26 & 124 & 1.05 & 111 & 1.43 & 124 & 2 & 21.08 & 34.30 & 21889 & -45.77 & -2.95 & -2.67 & -0.29 & -1.65 & 579 & 2.40 \\
\hline 11 & 200.0 & 283.2 & 287.0 & 3000 & 1752 & 84000 & 1.26 & 124 & 1.05 & 111 & 1.44 & 124 & 2 & 21.93 & 35.19 & & -48.27 & -2.97 & -2.69 & -0.29 & -1.66 & 573 & 2.43 \\
\hline 12 & 220.0 & 283.2 & 287.0 & 3000 & 1357 & 84000 & 1.26 & 124 & 1.05 & 111 & 1.44 & 124 & 2 & 22.78 & 36. & & -50.80 & -2.99 & -2.72 & -0.29 & -1.68 & 568 & 2.46 \\
\hline 13 & 240.0 & 283.2 & 287.0 & 3000 & 974 & 84000 & 1.26 & 124 & 1.05 & 111 & 1.44 & 124 & 2 & 23.63 & 36.98 & & -53.30 & -3.01 & -2.74 & -0.29 & & 563 & 2.49 \\
\hline 14 & 260.0 & 283.2 & 287.0 & 3000 & 592 & 84000 & 1.26 & 124 & 1.05 & 111 & 1.44 & 124 & 2 & 24.48 & 37.88 & & -55.84 & -3.03 & -2.76 & -0.29 & & 558 & 2.51 \\
\hline 15 & 280.0 & 283.2 & 287.0 & 3000 & 210 & 84000 & 1.26 & 124 & 1.06 & 111 & 1.44 & 124 & 2 & 25.34 & 38.78 & 27637 & -58.39 & -3.04 & -2.78 & -0.29 & -1.72 & 553 & 2.54 \\
\hline 16 & 291.2 & 283.2 & 287.0 & 3000 & 0 & 84000 & 1.26 & 124 & 1.06 & 111 & 1.43 & 124 & 2 & 25.81 & 39.28 & 28277 & -59.82 & -3.05 & -2.79 & -0.29 & -1.73 & 551 & 2.56 \\
\hline
\end{tabular}


Table 3.12. Main neutronics parameters in zero power states. Third cycle with 3 MOX LTAs of "Island-2" type

\begin{tabular}{|c|c|c|c|c|c|c|c|c|c|c|c|c|c|}
\hline $\mathbf{T}$ & $\begin{array}{l}\text { RO } \\
\text { pcm }\end{array}$ & $\begin{array}{c}\mathbf{C b} \\
\mathbf{p p m}\end{array}$ & Bank 10 & $\begin{array}{c}\text { Other } \\
\text { banks } \downarrow \uparrow\end{array}$ & $\mathrm{Xe}$ & Sm & $\underset{{ }^{\circ} \mathrm{C}}{\text { Tmod }}$ & $\begin{array}{c}\text { MTC } \\
\text { pem } /{ }^{\circ} \mathrm{C}\end{array}$ & $\begin{array}{c}\text { MDC } \\
\mathrm{pcm} / \mathrm{g} / \mathrm{cc}\end{array}$ & $\begin{array}{c}\text { DTC } \\
\mathrm{pem} /{ }^{\circ} \mathrm{C}\end{array}$ & $\begin{array}{l}\text { DRO/DCB } \\
\text { pcm/ppm }\end{array}$ & $\begin{array}{r}\lambda \mathrm{m} \\
* 10^{5} \mathrm{~s} \\
\end{array}$ & $\begin{array}{r}\beta \text { eff } \\
{ }^{*} 100 \\
\end{array}$ \\
\hline $\mathrm{BOC}$ & 0 & 8890 & $100 \% \uparrow$ & $100 \% \uparrow$ & 0 & Smh & 280 & -0.84 & 2090 & -2.96 & -1.50 & 2.11 & 0.65 \\
\hline EOC & 0 & 1930 & $100 \% \uparrow$ & $100 \% \uparrow$ & eq & Sm eq & 280 & -27.84 & 18940 & -3.31 & -1.78 & 2.45 & 0.56 \\
\hline BOC & $\begin{array}{c}-14285 \\
\left(\mathrm{RO}_{\text {STOP }}\right) \\
\end{array}$ & 16000 & $100 \% \uparrow$ & $100 \% \uparrow$ & 0 & Smh & 20 & & & & & & \\
\hline
\end{tabular}


Table 3.13. Pin Power Peaking Factors Attained During Fuel Cycle

\begin{tabular}{|c|c|c|c|c|c|c|c|c|c|c|c|c|c|c|c|c|c|c|c|c|c|c|c|}
\hline \multirow{4}{*}{$\begin{array}{c}T, \\
\text { EFPD }\end{array}$} & \multicolumn{7}{|c|}{$\mathbf{K r}$} & \multicolumn{4}{|c|}{$\mathbf{N}(\mathbf{K r})$} & \multicolumn{4}{|c|}{ Ko-total } & \multicolumn{4}{|c|}{$\mathbf{N}(\mathrm{Ko}$-total) } & \multicolumn{4}{|c|}{ M(Ko-total) } \\
\hline & UOX & \multicolumn{2}{|c|}{$\begin{array}{c}\mathrm{MOX} \\
1\end{array}$} & \multicolumn{2}{|c|}{$\begin{array}{c}\mathrm{MOX} \\
2\end{array}$} & \multicolumn{2}{|c|}{$\begin{array}{c}\text { MOX } \\
3\end{array}$} & \multirow[t]{3}{*}{ UOX } & \multirow{3}{*}{$\begin{array}{c}\text { MOX } \\
1\end{array}$} & \multirow[t]{3}{*}{$\begin{array}{c}\operatorname{MOX} \\
2\end{array}$} & \multirow{3}{*}{$\underset{3}{\mathrm{MOX}}$} & \multirow{3}{*}{$\begin{array}{c}\text { UOX } \\
\text { CORE }\end{array}$} & \multirow{3}{*}{$\begin{array}{c}\text { MOX } \\
1 \\
\\
\text { ALL } \\
\text { CORE }\end{array}$} & \multirow{3}{*}{$\begin{array}{c}\text { MOX } \\
2 \\
\\
\text { ALL } \\
\text { CORE }\end{array}$} & \multirow{3}{*}{$\begin{array}{c}\text { MOX } \\
3 \\
\\
\text { ALL } \\
\text { CORE }\end{array}$} & \multirow[t]{2}{*}{$\overline{U O X}$} & \multirow{2}{*}{$\begin{array}{c}\mathrm{MOX} \\
1\end{array}$} & \multirow{2}{*}{\begin{tabular}{|c|} 
MOX \\
2
\end{tabular}} & \multirow{2}{*}{$\begin{array}{c}\text { MOX } \\
3\end{array}$} & \multirow{2}{*}{$\begin{array}{l}\mathrm{U} \\
\mathrm{O} \\
\mathrm{X}\end{array}$} & \multirow{2}{*}{$\begin{array}{c}\mathrm{X} \\
1\end{array}$} & \multirow{2}{*}{\begin{tabular}{|c|}
$\mathrm{M}$ \\
$\mathrm{O}$ \\
$\mathrm{X}$ \\
2
\end{tabular}} & \multirow{2}{*}{\begin{tabular}{|l} 
\\
\\
$X$ \\
3
\end{tabular}} \\
\hline & $\overline{A L L}$ & ALL & MOX & ALL & & & & & & & & & & & & & & & & & & & \\
\hline & CORE & CORE & FA & CORE & $\mathrm{FA}$ & CORE & FA & & & & & & & & & & & & & & & & \\
\hline$\frac{0}{20}$ & 1.51 & 1.47 & 1.40 & 152 & 1.52 & 1.48 & 1.27 & 19 & 38 & 141 & 126 & 1.86 & 1.79 & 1.84 & 1.82 & 19 & 38 & 153 & 126 & 4 & 4 & 4 & 4 \\
\hline 20 & 1.49 & 1.40 & 1.33 & 1.50 & 1.50 & 1.42 & 1.29 & 19 & 38 & $\sqrt{141}$ & 124 & 1.80 & 1.68 & $1 \% 7$ & 1.71 & 19 & 38 & 141 & 124 & 4 & 4 & 4 & 4 \\
\hline 40 & 1.48 & 1.40 & 1.30 & 148 & $\sqrt{1.48}$ & 1.41 & 1.28 & 19 & 40 & 141 & 124 & 1.76 & 1.65 & 1.72 & 1.67 & 19 & 38 & 141 & 124 & 4 & 4 & 4 & 4 \\
\hline 60 & 1.47 & 1.39 & 1.29 & 146 & 146 & 1.40 & 1.27 & 19 & 40 & 141 & 124 & 1.72 & 1.62 & 1.66 & 1.63 & 19 & 47 & 18 & 124 & 3 & 3 & 4 & 4 \\
\hline 80 & 1.45 & 1.38 & 1.27 & 144 & 1.44 & 1.39 & 1.26 & 19 & 72 & 18 & 124 & 1.69 & 1.59 & 1.63 & 1.60 & 19 & 132 & 18 & 124 & 3 & 3 & 3 & 3 \\
\hline 100 & 1.44 & 1.37 & 1.26 & 1.42 & 142 & 1.37 & 1.26 & 19 & 72 & 18 & 124 & 1.66 & 1.58 & 1660 & 1.58 & 19 & 72 & 18 & 124 & 3 & 3 & 3 & 3 \\
\hline 120 & 1.43 & 1.37 & 1.25 & 1141 & 14. & 1.36 & 1.24 & 19 & 72 & 18 & 124 & 1.64 & 1.57 & 157 & 1.56 & 19 & 72 & 718 & 124 & 3 & 3 & 3 & 3 \\
\hline 140 & 1.42 & 1.36 & 1.24 & 140 & $1 / 40$ & 1.35 & 1.24 & 19 & 72 & 18 & 124 & 1.62 & 1.55 & $15 \%$ & 1.54 & 19 & 124 & 18 & 124 & 3 & 3 & 3 & 3 \\
\hline 160 & 1.41 & 1.36 & 1.23 & 3138 & 1.36 & 1.34 & 1.23 & 19 & 72 & 18 & 124 & 1.60 & 1.54 & 153 & 1.52 & 19 & 124 & 18 & 124 & 3 & 3 & 2 & 3 \\
\hline 180 & 1.39 & 1.35 & 1.22 & 137 & 137 & 1.33 & 1.23 & 19 & 124 & 18 & 124 & 1.58 & 1.54 & 135 & 1.51 & 19 & 124 & 18 & 124 & 3 & 2 & 2 & 2 \\
\hline 200 & 1.38 & 1.35 & 1.21 & 136 & 136 & 1.32 & 1.23 & 19 & 124 & $18^{17}$ & 124 & 1.57 & 1.53 & 151 & 1.50 & 19 & 124 & 18 & 124 & 2 & 2 & 2 & 2 \\
\hline 220 & 1.37 & 1.34 & 1.20 & 135 & 1.35 & 1.32 & 1.22 & 19 & 124 & $188^{2}$ & 124 & 1.56 & 1.53 & 1.50 & 1.50 & 19 & 124 & 110 & 124 & 2 & 2 & 2 & 2 \\
\hline 240 & 1.36 & 1.34 & 1.20 & 133 & 1133 & 1.31 & 1.22 & 19 & 124 & 18 & 124 & 1.55 & 1.52 & 1.49 & 1.49 & 19 & 124 & 110 & 124 & 2 & 2 & 2 & 2 \\
\hline 260 & 1.35 & 1.33 & 1.19 & 132 & 132 & 1.30 & 1.22 & 19 & 124 & 18 & 124 & 1.54 & 1.52 & 1.49 & 1.48 & 19 & 124 & 110 & 124 & 2 & 2 & 2 & 2 \\
\hline 280 & 1.34 & 1.32 & 1.19 & $11.31 \%$ & 1131 & 1.30 & 1.21 & 6 & 124 & 18 & 124 & 1.53 & 1.51 & 1.48 & 1.48 & 19 & 124 & 56 & 124 & 2 & 2 & 2 & 2 \\
\hline EOC & 1.34 & 1.32 & 1.19 & 131 & 131 & 1.30 & 1.21 & 6 & 124 & 18 & 124 & 1.52 & 1.51 & 1.48 & 1.47 & 19 & 124 & 56 & 124 & 2 & 2 & 2 & 2 \\
\hline
\end{tabular}

Power peaking factor is attained in MOX LTA 


\section{Table 3.14. Core Subcriticality (Scram Margin) in different states in the process of Scram actuation}

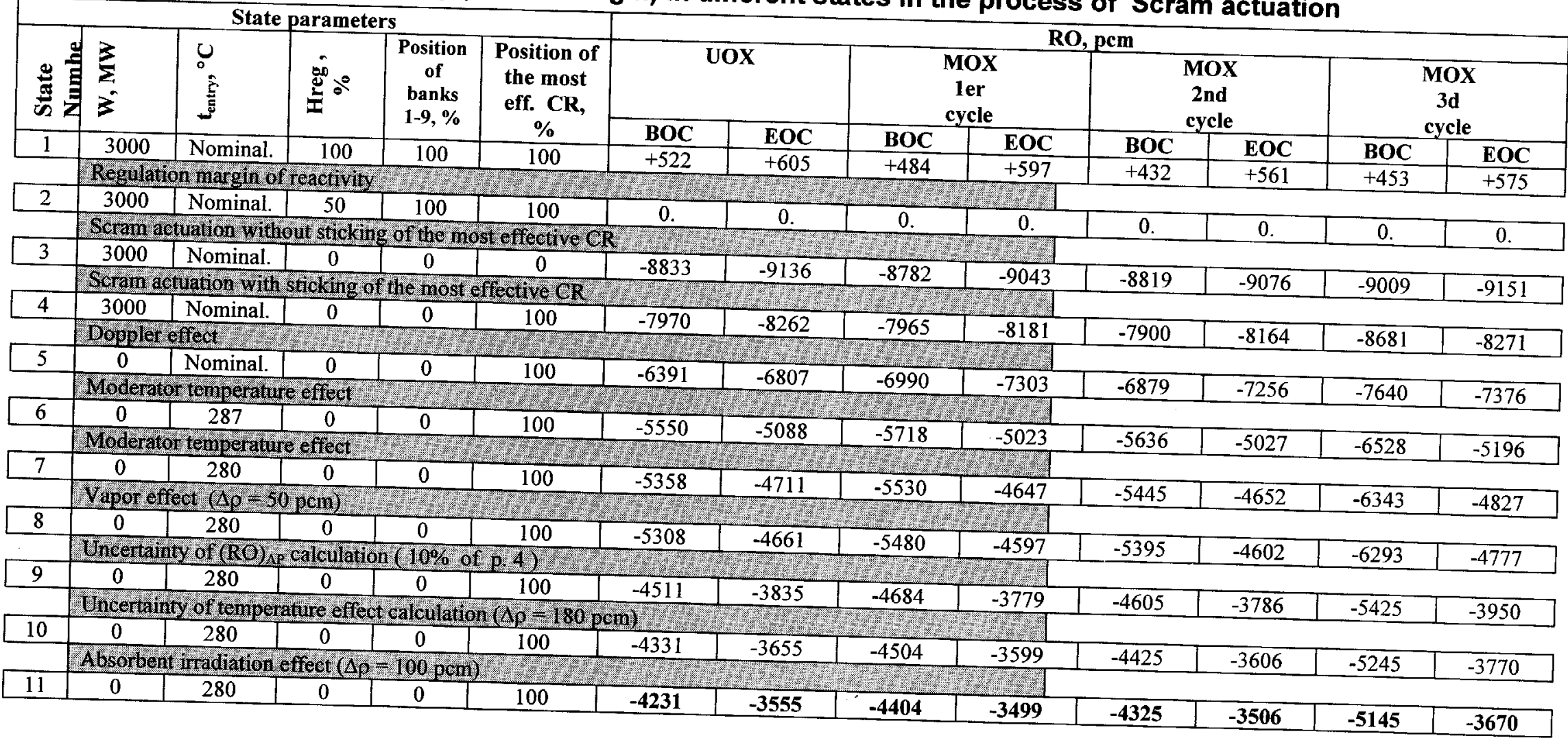


RUSSIAN RESEARCH CENTER KURCHATOV INSTITUTE

Design Studies of "Island" Type MOX Lead Test Assembly (Report for FY99)

Table 3.15a. Control rods worth calculation. States description

\begin{tabular}{|c|c|c|c|c|c|}
\hline V1. BOC & V2. BOC & V3. BOC & V1. EOC & V1. EOC & V1. EOC \\
\hline S1 & S1 & S1 & S1 & S1 & S1 \\
\hline Wnom, & MCL, & MCL, & Wnom, & MCL, & $\mathrm{MCL}_{2}$ \\
\hline $\begin{aligned} \mathrm{Xe} & =\mathrm{Xe} e q, \\
& =287^{\circ} \mathrm{C}\end{aligned}$ & $\begin{aligned} \mathrm{Xe} & =0, \\
& =280^{\circ} \mathrm{C}\end{aligned}$ & $\begin{aligned} \mathrm{Xe} & =\mathrm{Xe} \text { eq, } \\
& =280^{\circ} \mathrm{C}\end{aligned}$ & $\begin{aligned} \mathrm{Xe} & =\mathrm{Xe} \mathrm{eq}, \\
& =287^{\circ} \mathrm{C}\end{aligned}$ & $\begin{aligned} \mathrm{Xe} & =\mathrm{Xe} \mathrm{eq}, \\
\mathrm{t} & =280^{\circ} \mathrm{C}\end{aligned}$ & $\begin{array}{c}\mathrm{Xe}=0, \\
=280^{\circ} \mathrm{C}\end{array}$ \\
\hline $\begin{array}{l}t_{\text {entry }}=287^{\circ} \mathrm{C}, \\
\mathrm{Cb} \text { burnup }\end{array}$ & $\mathrm{Cb}$ crit & $\mathrm{Cb}$ crit & $\mathrm{Cb}$ burnup & $\mathrm{Cb}$ crit & $\mathrm{Cb}$ crit \\
\hline $\begin{array}{c}100 \% 5 \downarrow^{*} \\
30 \%\end{array}$ & $30 \% 10 \downarrow$ & $30 \% 10 \downarrow$ & $\begin{array}{c}100 \% 5 \downarrow \\
30 \% 10 \downarrow\end{array}$ & $\begin{array}{c}100 \% \quad 5 \downarrow \\
30 \% 10 \downarrow\end{array}$ & $\begin{array}{c}100 \% 5 \downarrow \\
30 \% 10 \downarrow\end{array}$ \\
\hline $\begin{array}{l}\text { S2: the same } \\
\text { but }\end{array}$ & $\begin{array}{l}\text { S2: the same } \\
\text { but }\end{array}$ & $\begin{array}{l}\text { S2: the same } \\
\text { but }\end{array}$ & $\begin{array}{l}\text { S2: the same } \\
\text { but }\end{array}$ & $\begin{array}{l}\text { S2: the same } \\
\text { but }\end{array}$ & $\begin{array}{l}\text { S2: the same } \\
\text { but }\end{array}$ \\
\hline $100 \% 1-10 \downarrow$ & $100 \% 1-10 \downarrow$ & $100 \% 1-10 \downarrow$ & $100 \% 1-10 \downarrow$ & $100 \% 1-10 \downarrow$ & $100 \% 1-10 \downarrow$ \\
\hline
\end{tabular}

Table 3.15b. Control rods worth in Uranium reference core and in 3 MOX LTAs loaded cores (pcm)

\begin{tabular}{|c|c|c|c|c|c|c|c|c|c|c|c|c|c|}
\hline & & \multicolumn{3}{|c|}{ Uranium Core } & \multicolumn{3}{|c|}{ MOX-1 } & \multicolumn{3}{|c|}{ MOX-2 } & \multicolumn{3}{|c|}{ MOX-3 } \\
\hline & Variant & V1 & V2 & V3 & V1 & V2 & V3 & V1 & V2 & $\mathbf{V 3}$ & V1 & V2 & $\mathbf{V 3}$ \\
\hline \multirow{2}{*}{ BOC } & Stuck rod number & 55 & 55 & 55 & 67 & 67 & 67 & 109 & 82 & 82 & 112 & 97 & 97 \\
\hline & $(\mathrm{RO})_{\mathrm{AP}}$ & 6930 & 6770 & 6730 & 6980 & 6830 & 6800 & 6960 & 6790 & 6730 & 7700 & 7150 & 7120 \\
\hline \multirow{2}{*}{ EOC } & Stuck rod number & 55 & 55 & 55 & 97 & 97 & 97 & 55 & 97 & 97 & 97 & 55 & 55 \\
\hline & $(\mathbf{R O})_{\mathrm{AP}}$ & 7200 & 6150 & 6150 & 7100 & 6010 & 5990 & 7140 & 6090 & 6120 & 7170 & 6190 & 6170 \\
\hline
\end{tabular}

' $\mathrm{X} \% \mathrm{~N} \downarrow$ means that the Bank $\mathrm{N}$ is $\mathrm{X} \%$ inserted in core 
RUSSIAN RESEARCH CENTER KURCHATOV INSTITUTE

Design Studies of "Island" Type MOX Lead Test Assembly (Report for FY99)

Table 3.16. Core reactivity in the process of control rods movement

\begin{tabular}{|c|c|c|c|c|c|c|c|c|}
\hline \multirow{3}{*}{$\begin{array}{c}\text { AP } \\
\text { Position, } \% \\
\text { (Hreg=80\%) }\end{array}$} & \multicolumn{8}{|c|}{ BOC } \\
\hline & \multicolumn{2}{|c|}{ Uranium } & \multicolumn{2}{|c|}{ MOX-1 } & \multicolumn{2}{|c|}{ MOX-2 } & \multicolumn{2}{|c|}{ MOX-3 } \\
\hline & No stuck & $\begin{array}{l}\text { Stuck } \\
\text { N } 55\end{array}$ & No stuck & $\begin{array}{c}\text { Stuck } \\
\text { N } 67\end{array}$ & $\begin{array}{c}\text { No } \\
\text { stuck }\end{array}$ & $\begin{array}{l}\text { Stuck } \\
\text { N } 109\end{array}$ & $\begin{array}{c}\text { No } \\
\text { stuck }\end{array}$ & $\begin{array}{l}\text { Stuck } \\
\text { N } 112\end{array}$ \\
\hline 100 & 0 & 0 & 0 & 0 & 0 & 0 & 0 & 0 \\
\hline 90 & -120 & -120 & -120 & -120 & -120 & -110 & -120 & -120 \\
\hline 80 & -210 & -210 & -210 & -210 & -200 & -200 & -210 & -200 \\
\hline 70 & -310 & -310 & -310 & -310 & -300 & -290 & -300 & -300 \\
\hline 60 & -460 & -460 & -450 & -450 & -430 & -430 & -440 & -440 \\
\hline 50 & -700 & -700 & -690 & -680 & -660 & -660 & -680 & -670 \\
\hline 40 & -1150 & -1140 & -1110 & -1110 & -1070 & -1070 & -1090 & -1090 \\
\hline 30 & -2000 & -1990 & -1920 & -1920 & -1860 & -1850 & -1900 & -1890 \\
\hline 20 & -3620 & -3590 & -3500 & -3480 & -3430 & -3410 & -3490 & -3470 \\
\hline 10 & -7050 & -6810 & -6950 & -6740 & -6910 & -6660 & -7010 & -6890 \\
\hline 0 & -9150 & -8330 & -9070 & -8300 & -9070 & -8190 & -9270 & -8940 \\
\hline
\end{tabular}

\begin{tabular}{|c|c|c|c|c|c|c|c|c|}
\hline \multirow{3}{*}{$\begin{array}{c}\text { AP } \\
\text { Position,\% } \\
\text { (Hreg }=80 \% \text { ) }\end{array}$} & \multicolumn{8}{|c|}{ EOC } \\
\hline & \multicolumn{2}{|c|}{ Uranium } & \multicolumn{2}{|c|}{ MOX-1 } & \multicolumn{2}{|c|}{ MOX-2 } & \multicolumn{2}{|c|}{ MOX-3 } \\
\hline & No stuck & $\begin{array}{l}\text { Stuck } \\
\text { N } 55\end{array}$ & No stuck & $\begin{array}{l}\text { Stuck } \\
\text { N } 97\end{array}$ & $\begin{array}{c}\text { No } \\
\text { stuck }\end{array}$ & $\begin{array}{c}\text { Stuck } \\
\text { N } 97\end{array}$ & $\begin{array}{c}\text { No } \\
\text { stuck }\end{array}$ & $\begin{array}{c}\text { Stuck } \\
\text { N } 97\end{array}$ \\
\hline 100 & 0 & 0 & 0 & 0 & 0 & 0 & 0 & 0 \\
\hline 90 & -140 & -140 & -140 & -140 & -130 & -130 & -140 & -140 \\
\hline 80 & -190 & -190 & -190 & -190 & $\therefore-190$ & -190 & -190 & -190 \\
\hline 70 & -260 & -260 & -260 & -250 & -250 & -250 & -260 & -260 \\
\hline 60 & -360 & -360 & -350 & -350 & -350 & -350 & -350 & -350 \\
\hline 50 & -530 & -530 & -530 & -530 & -520 & -520 & -530 & -520 \\
\hline 40 & .880 & -870 & -870 & -860 & -850 & -850 & -860 & -860 \\
\hline 30 & -1590 & -1580 & -1570 & -1560 & -1530 & -1530 & -1550 & -1540 \\
\hline 20 & -3000 & -2980 & -2950 & -2930 & -2900 & -2890 & -2920 & -2900 \\
\hline 10 & -6300 & -6160 & -6190 & -6050 & -6170 & -6020 & -6200 & -6060 \\
\hline 0 & -9410 & -8570 & -9310 & -8480 & -9320 & -8440 & -9400 & -8560 \\
\hline
\end{tabular}


RUSSIAN RESEARCH CENTER KURCHATOV INSTITUTE

Design Studies of "Island" Type MOX Lead Test Assembly (Report for FY99)

Table 3.17. Return Criticality Temperature

\begin{tabular}{|c|c|c|c|c|}
\hline & UOX & MOX-1 & MOX-2 \\
\hline RCT, ${ }^{\circ} \mathrm{C}$ & 124 & 128 & 128 \\
\hline
\end{tabular}


Figure 2.1. Simplified Design for Uranium Reference Assembly (Type A)

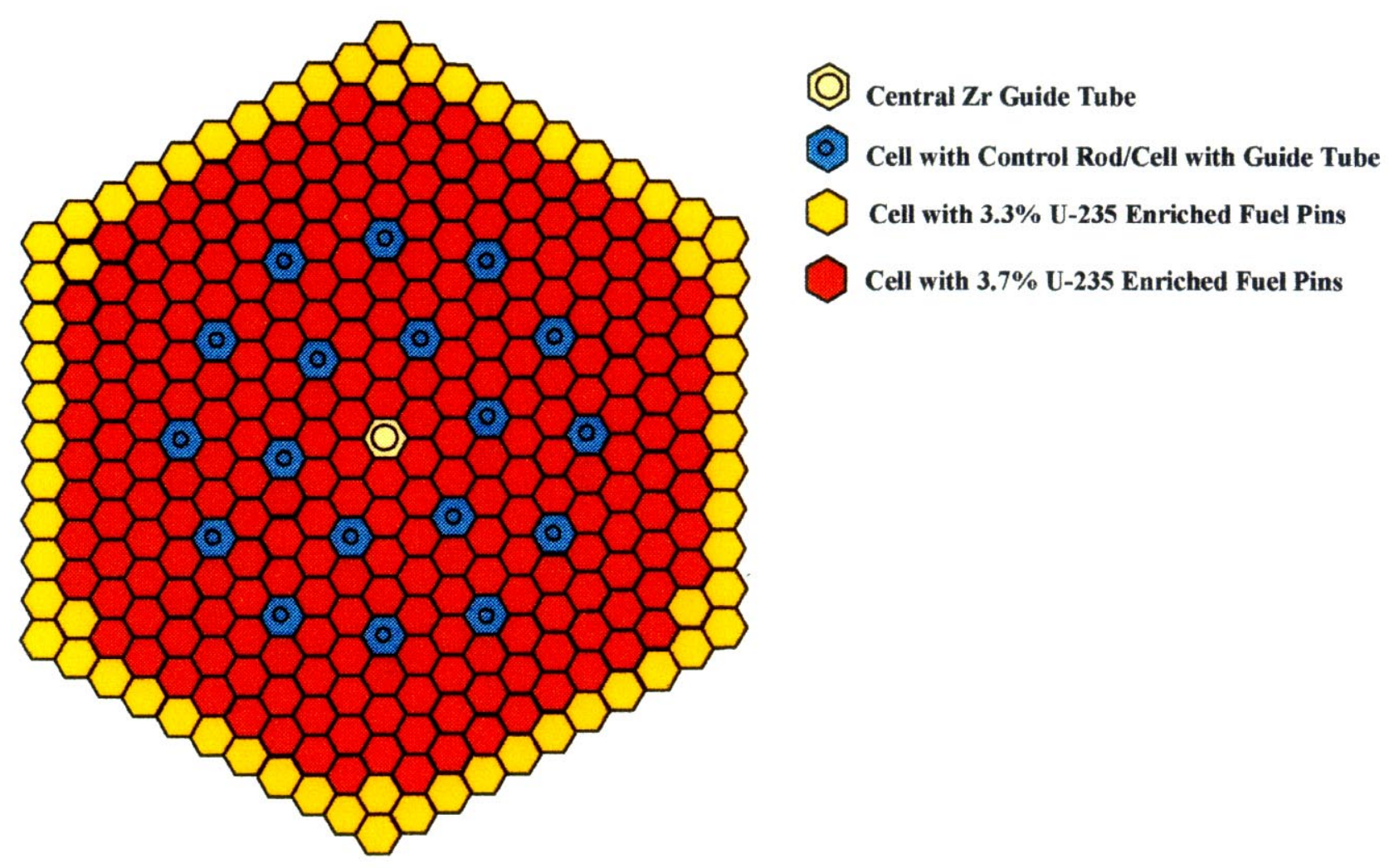


Figure 2.2. Calculational Model for Reference Uranium Assembly Surrounded by Uranium Assemblies. $60^{\circ}$ Sector

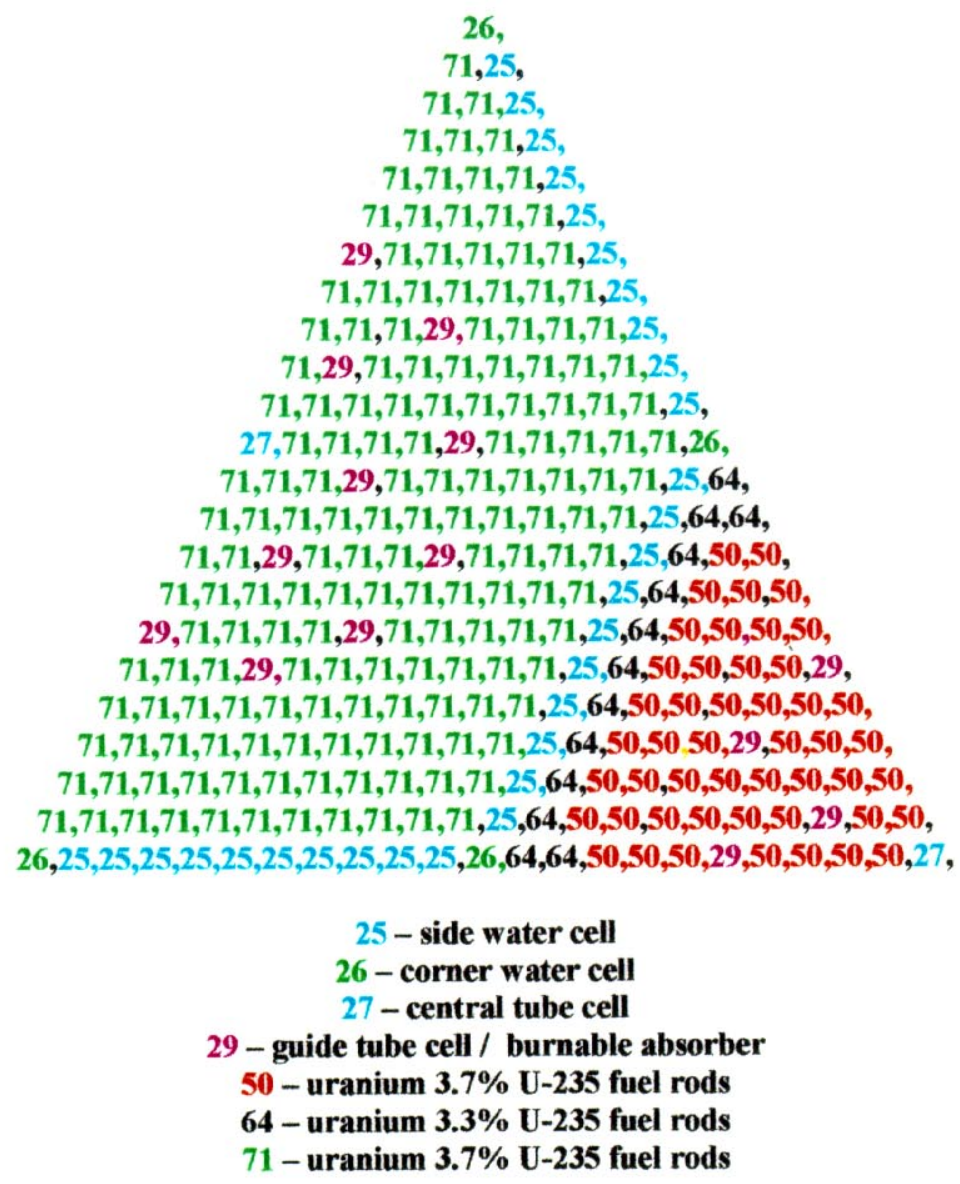




\section{Figure 2.3. Simplified Design for Uranium Assembly (Types $B$ and $B a$ )}

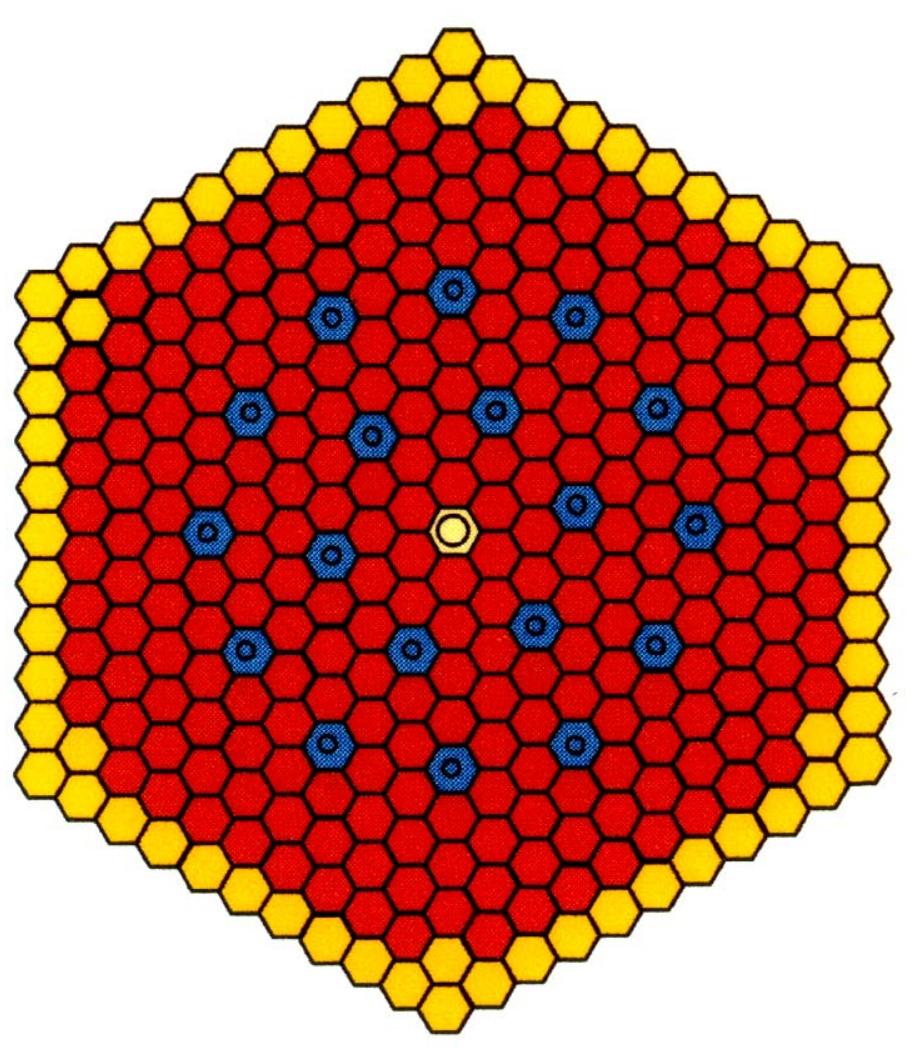

(2) Central Zr Guide Tube

- Cell with Burnable Absorber/Cell with Guide Tube

B: $\quad 0,065 \mathrm{~g} / \mathrm{cc}$ for Boron density

Ba: $0,036 \mathrm{~g} / \mathrm{cc}$ for Boron density

Cell with 3.3\% U-235 Enriched Fuel Pins

Cell with 3.7\% U-235 Enriched Fuel Pins 


\section{Figure 2.4. Simplified Design for Uranium Assembly (Type C)}

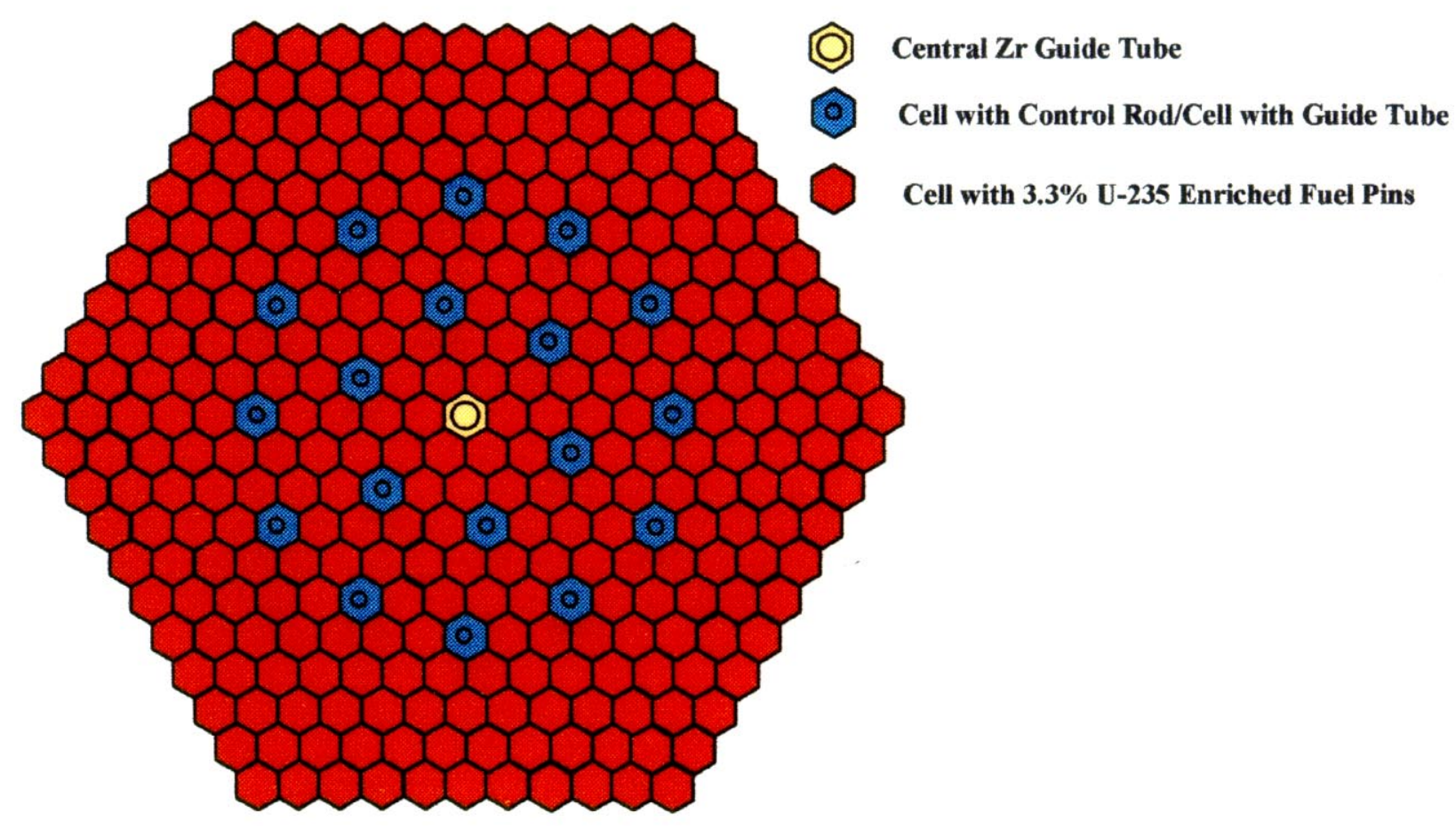




\section{Figure 2.5. Simplified Design for 100 \% Plutonium (3 Zones) MOX LTA}

Guide Tube

- Central tube

High Plutonium-Content MOX Rods

Low Plutonium-Content MOX Rods

Intermediate Plutonium-Content MOX Rods

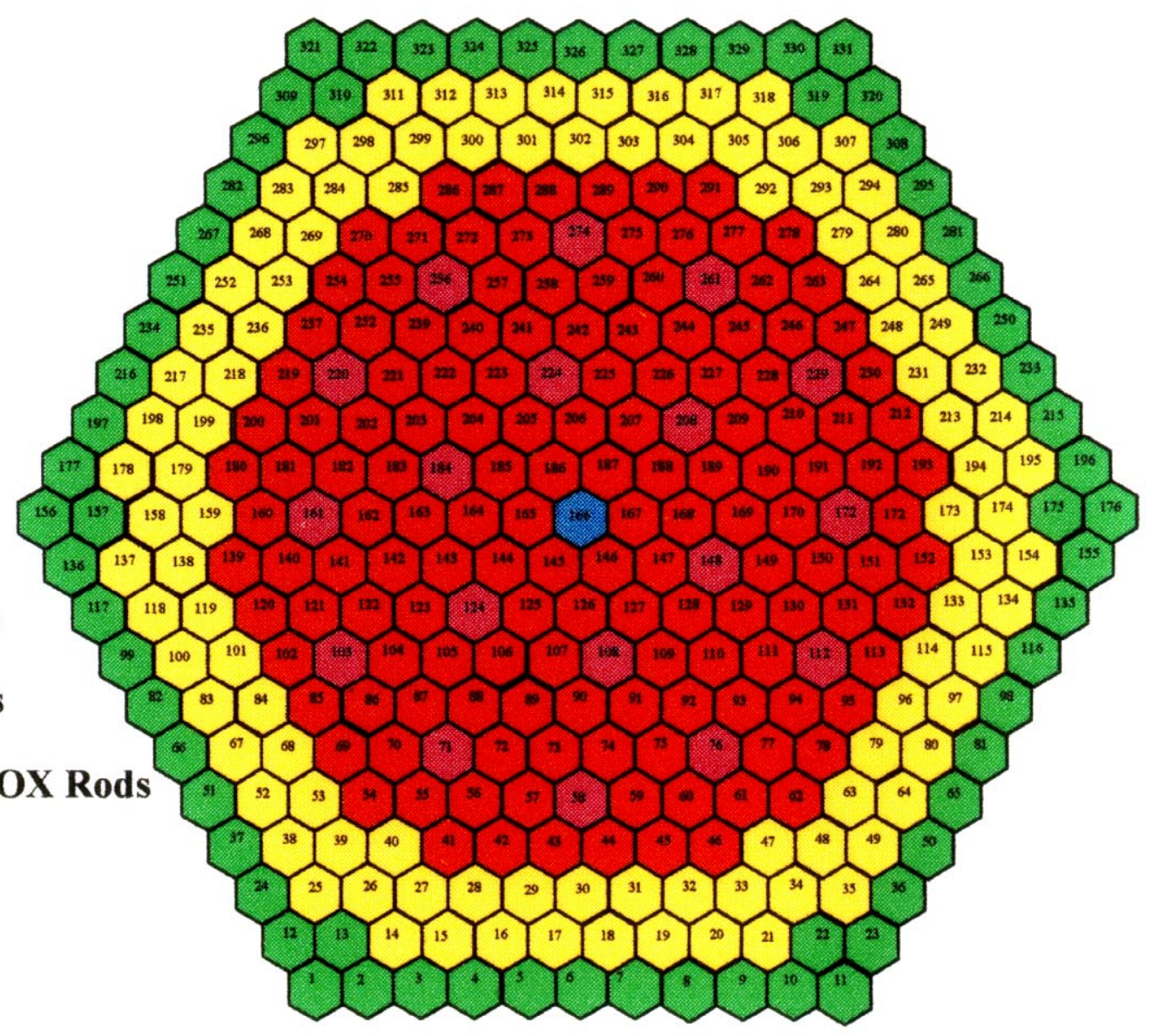


Figure 2.6. Calculational Model for 3-Zones (100\% Plutonium) MOX LTA Surrounded by Uranium Assemblies. $60^{\circ}$ Sector

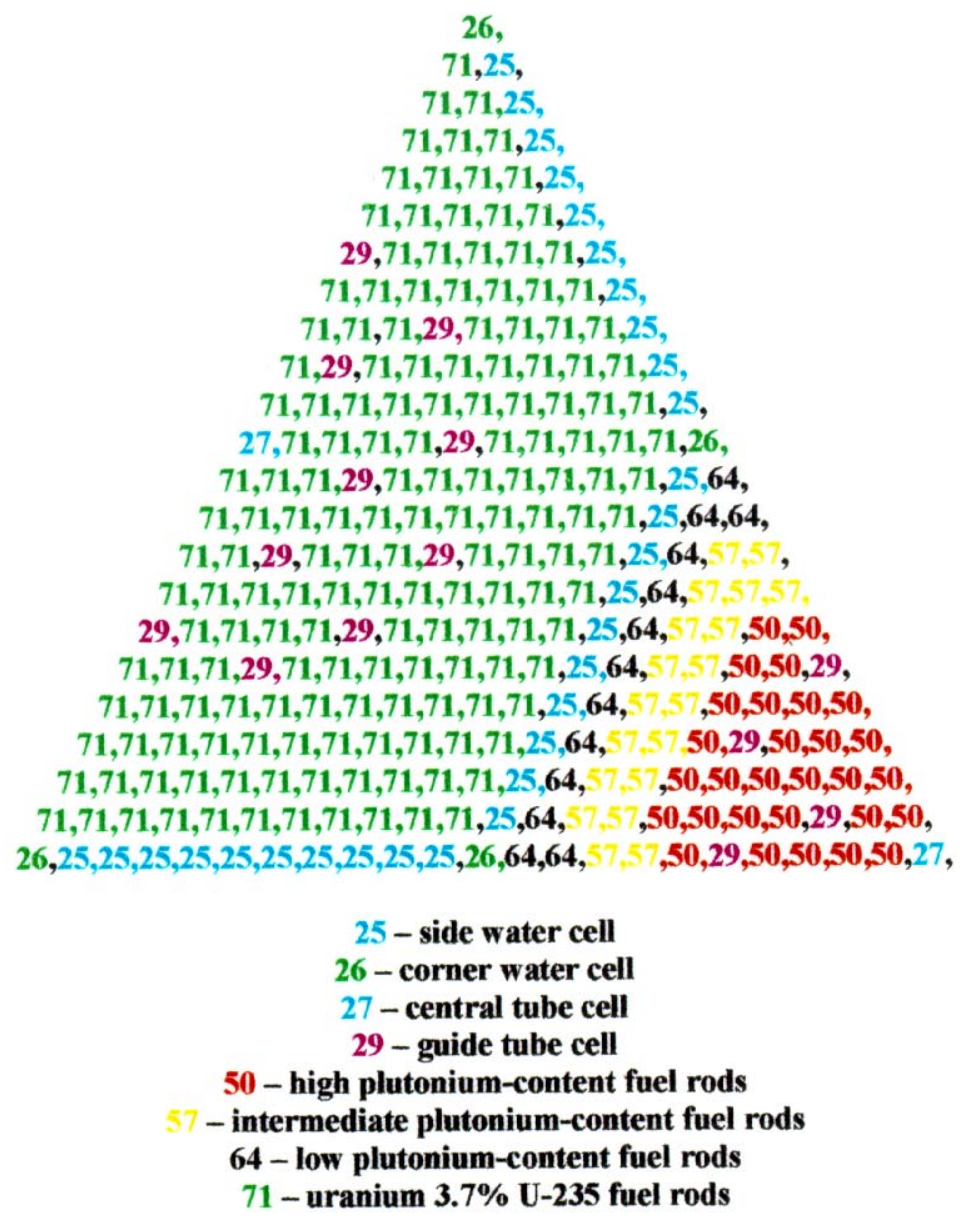


Figure 2.7. Simplified Design for "Island-1" Type MOX LTA

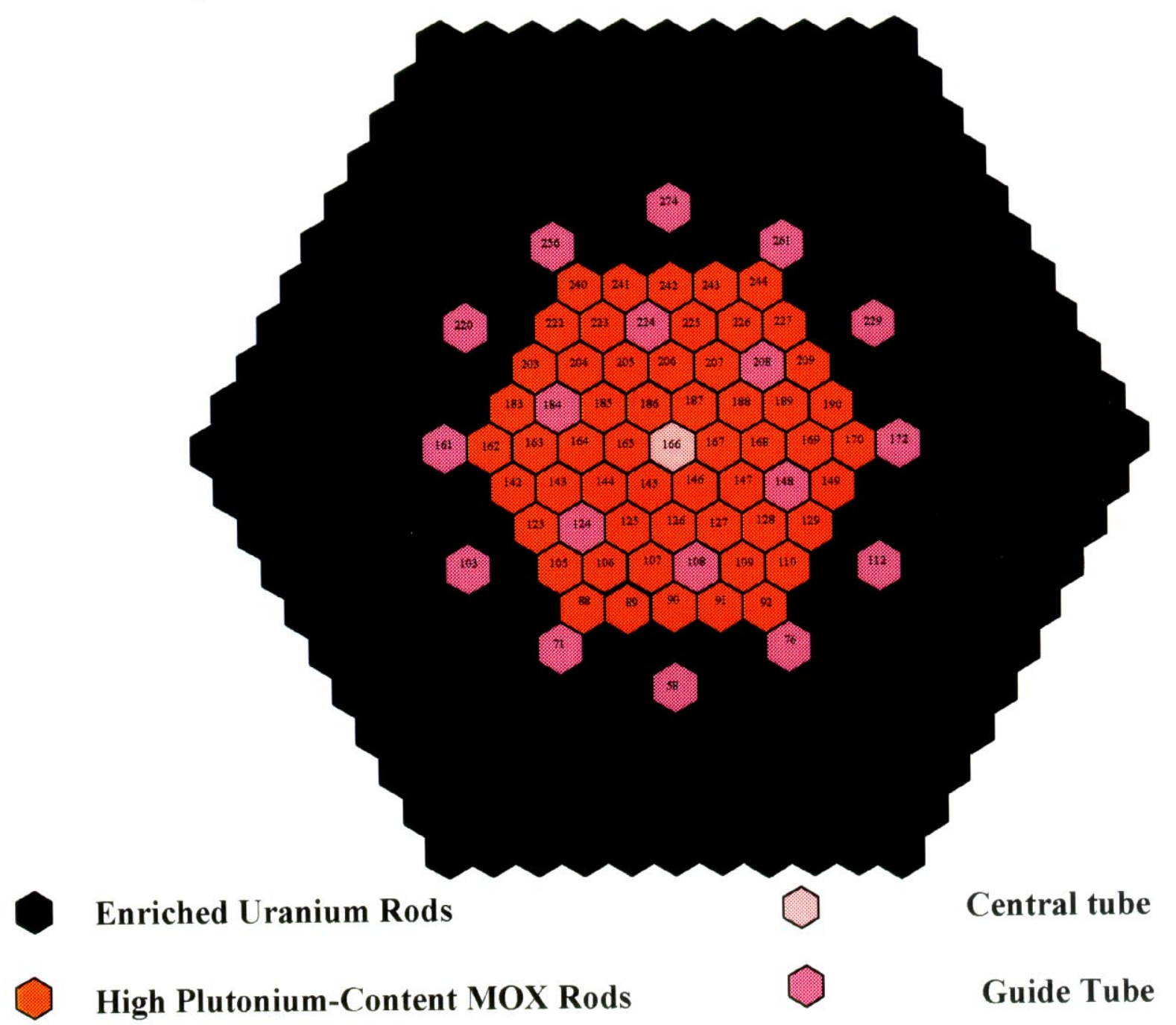


RUSSIAN RESEARCH CENTER KURCHATOV INSTITUTE

Design Studies of "Island" Type MOX Lead Test Assembly (Report for FY99)

Figure 2.8. Calculational Model for "Island-1" MOX LTA Surrounded by Uranium Assemblies. $60^{\circ}$ Sector

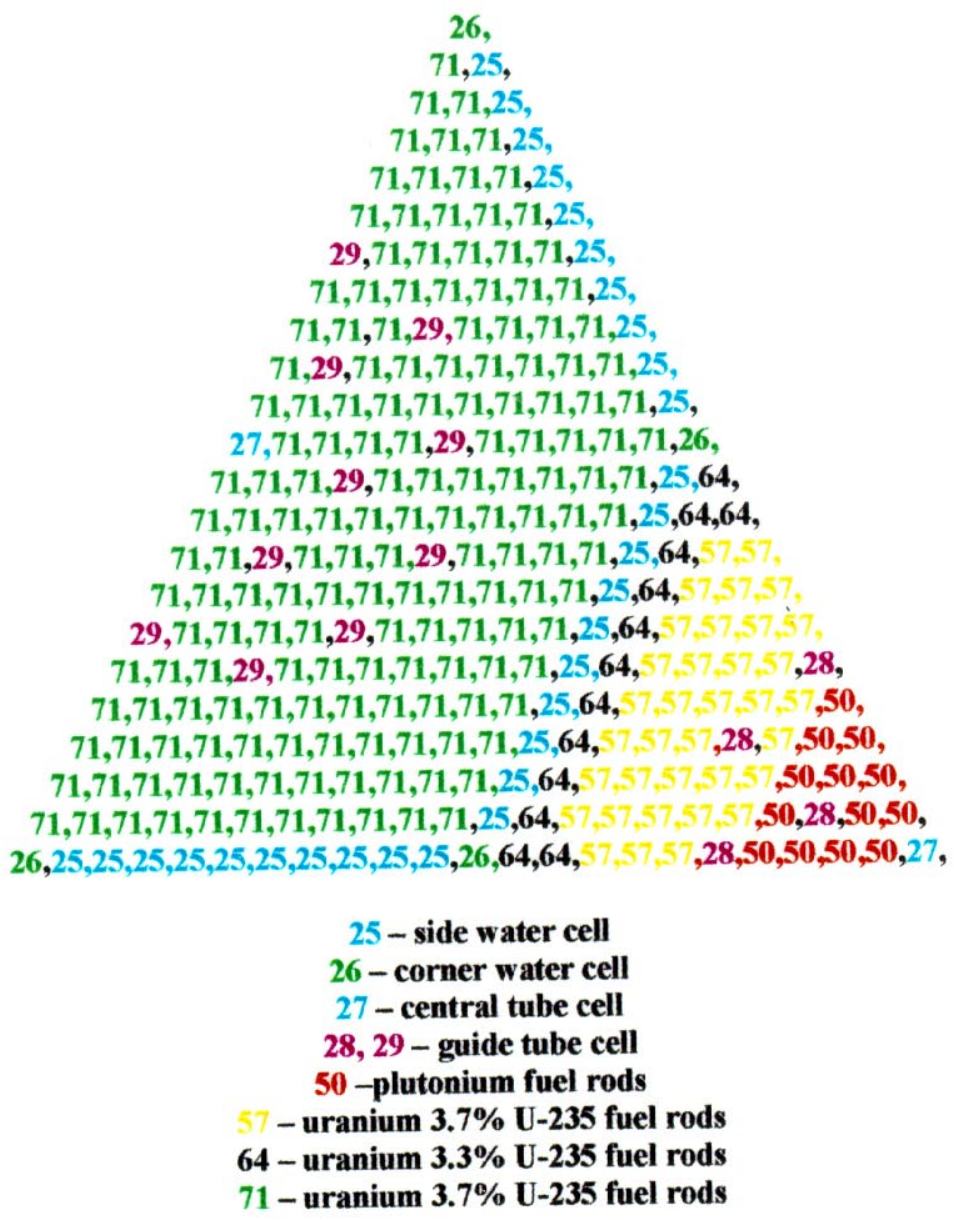


Figure 2.9. Simplified Design for "Island-2" Type MOX LTA

Enriched Uranium Rods

High Plutonium-Content MOX Rods

$\bigcirc$ Intermediate Plutonium-Content MOX Rods

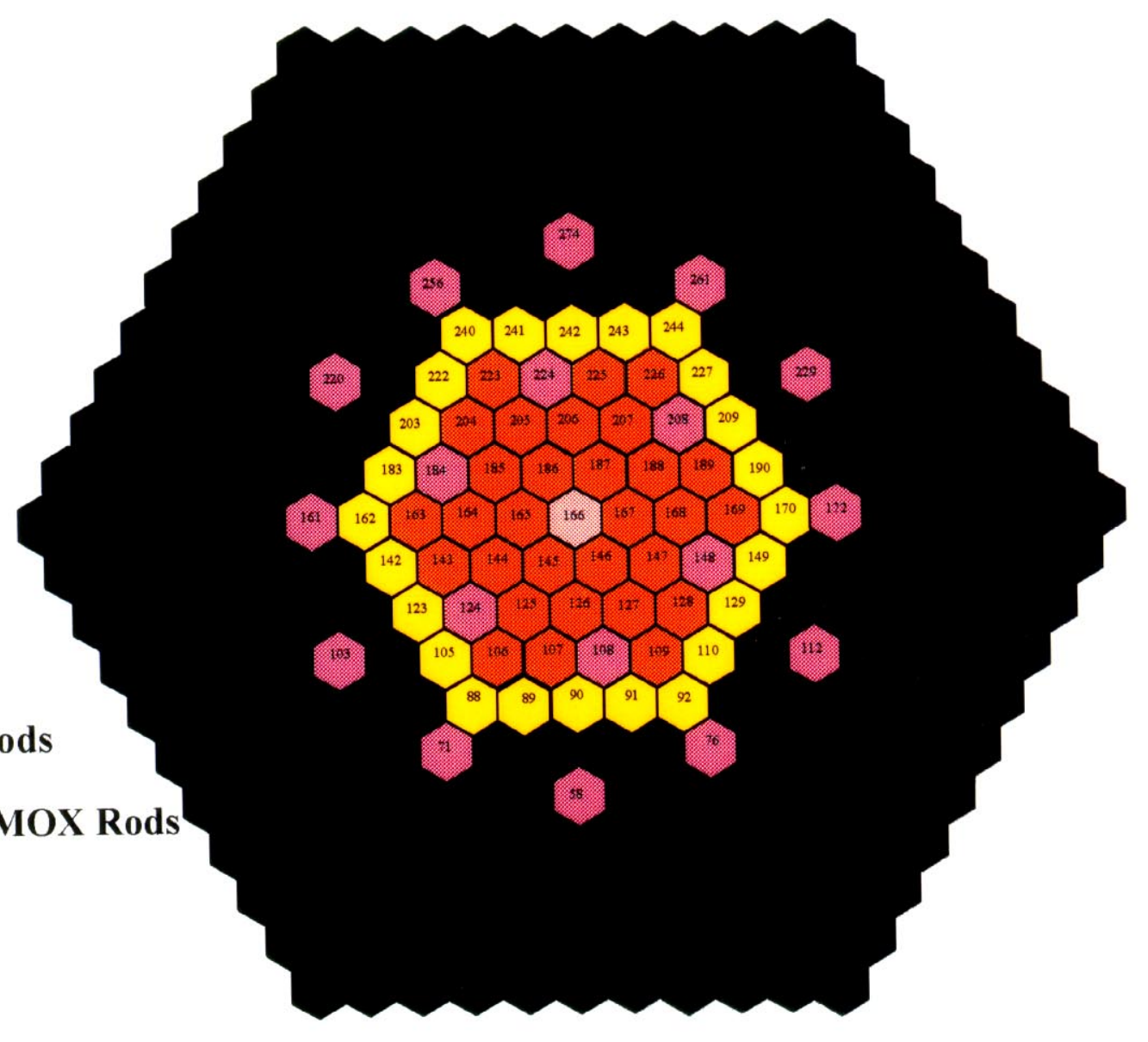

Central tube

Guide Tube 
RUSSIAN RESEARCH CENTER KURCHATOV INSTITUTE

Design Studies of "Island" Type MOX Lead Test Assembly (Report for FY99)

Figure 2.10. Calculational Model for "Island-2" MOX LTA Surrounded by Uranium Assemblies. $60^{\circ}$ Sector

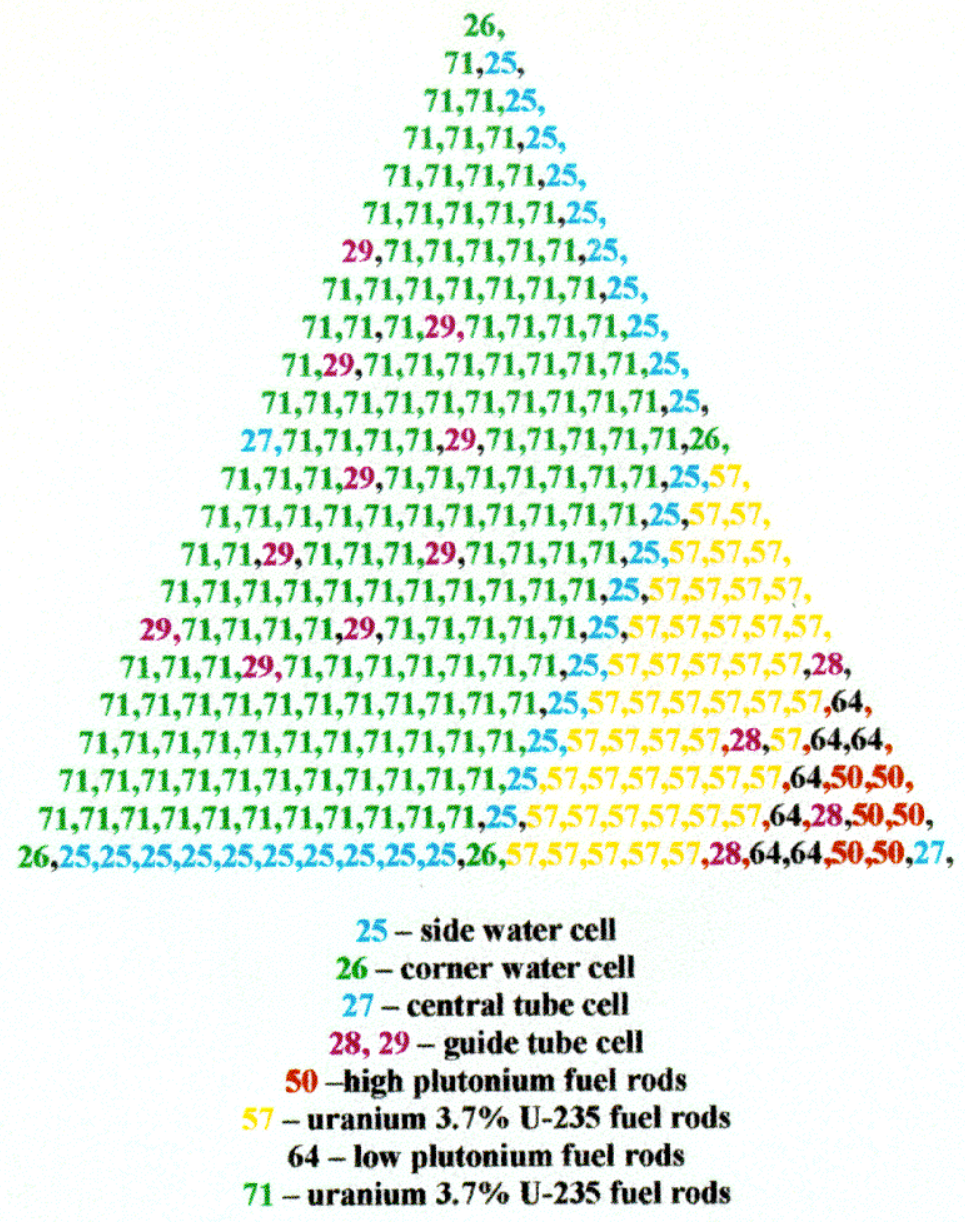


RUSSIAN RESEARCH CENTER KURCHATOV INSTITUTE

Design Studies of "Island" Type MOX Lead Test Assembly (Report for FY99)

Figure 2.11. Pins Numeration in CS Model

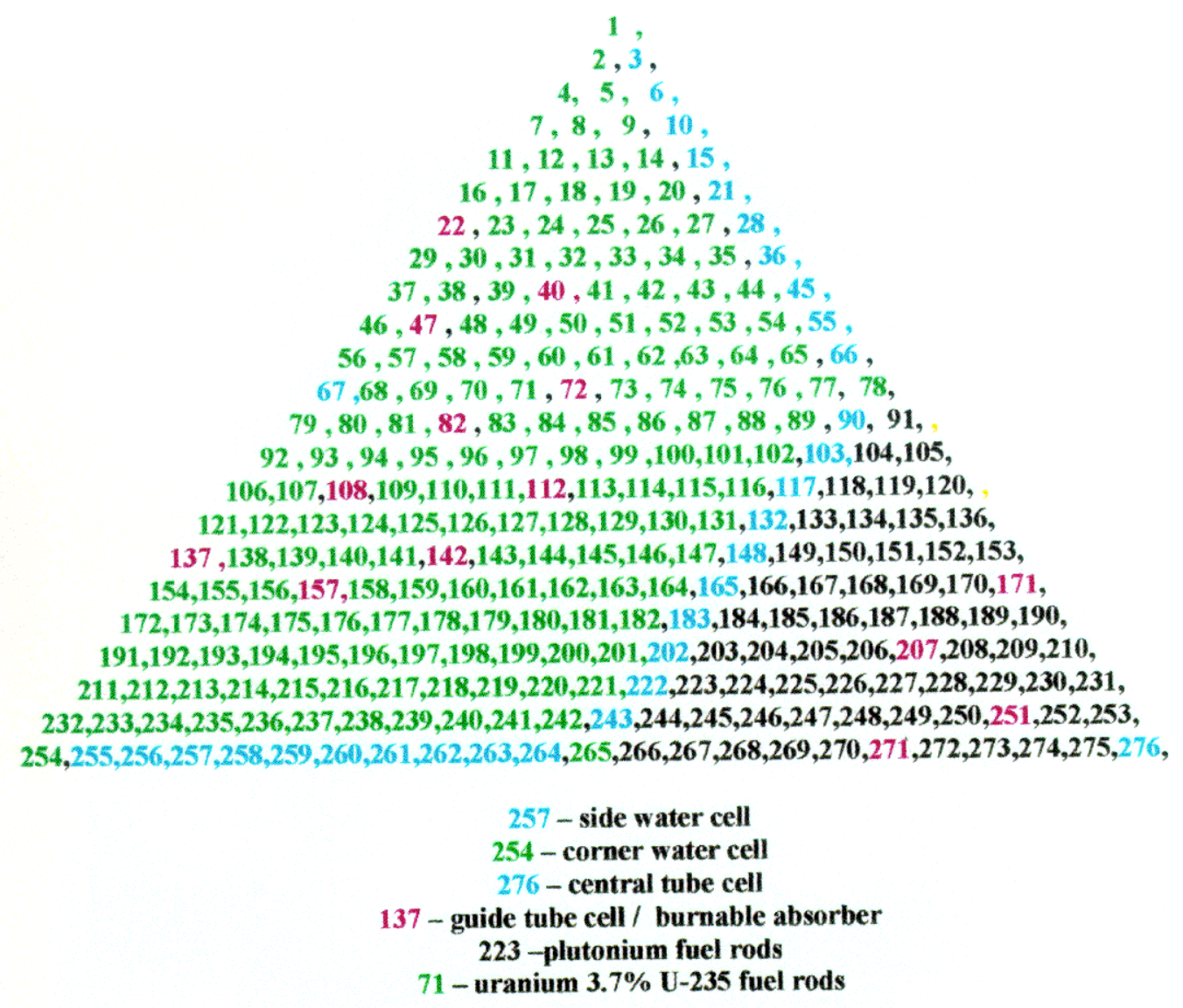




\section{Figure 2.12. Evolution of Ko in Plutonium-Uranium Super-Cells}

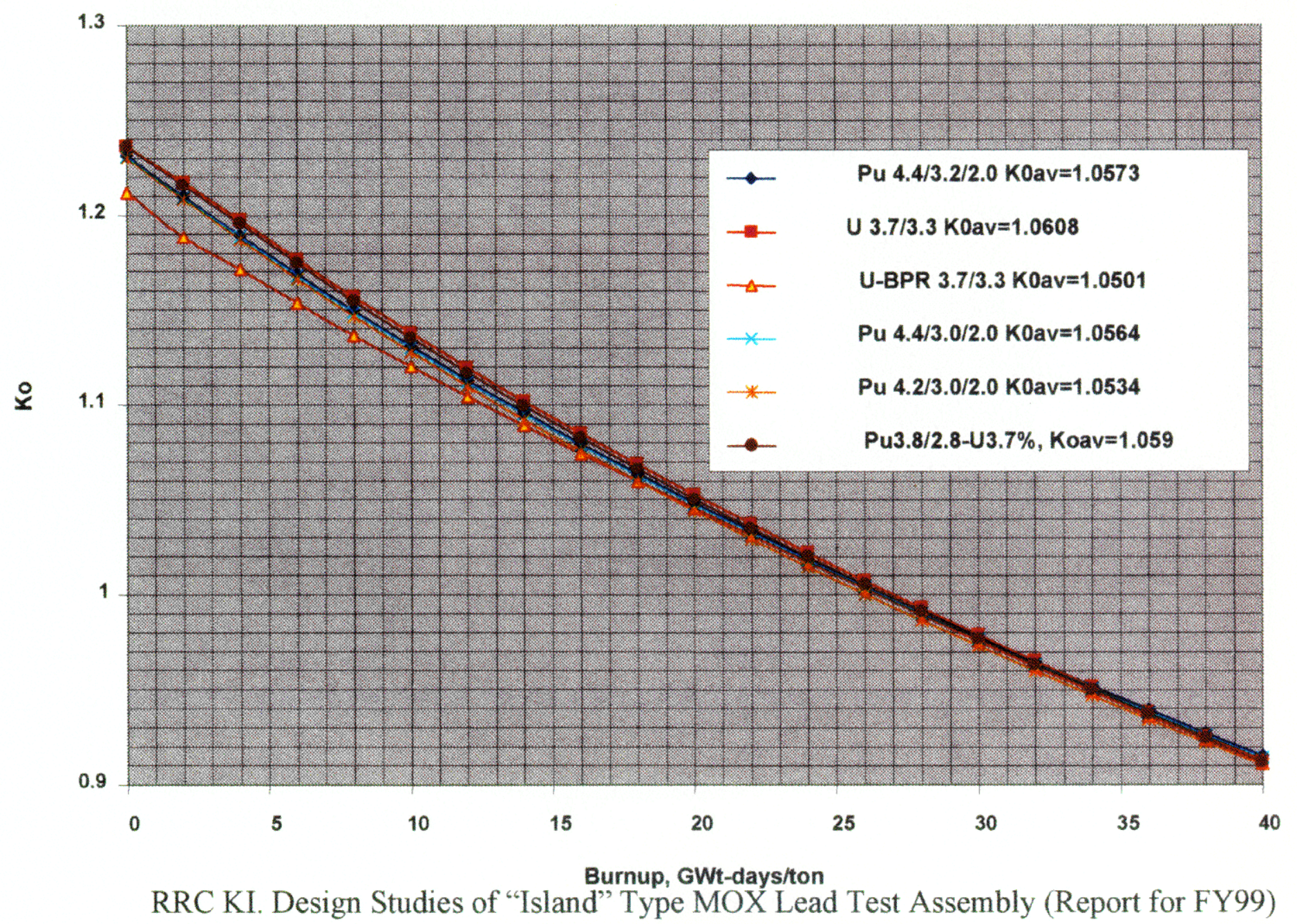




\section{Figure 2.13. Evolution of $K k$ in Plutonium-Uranium Super-Cells}

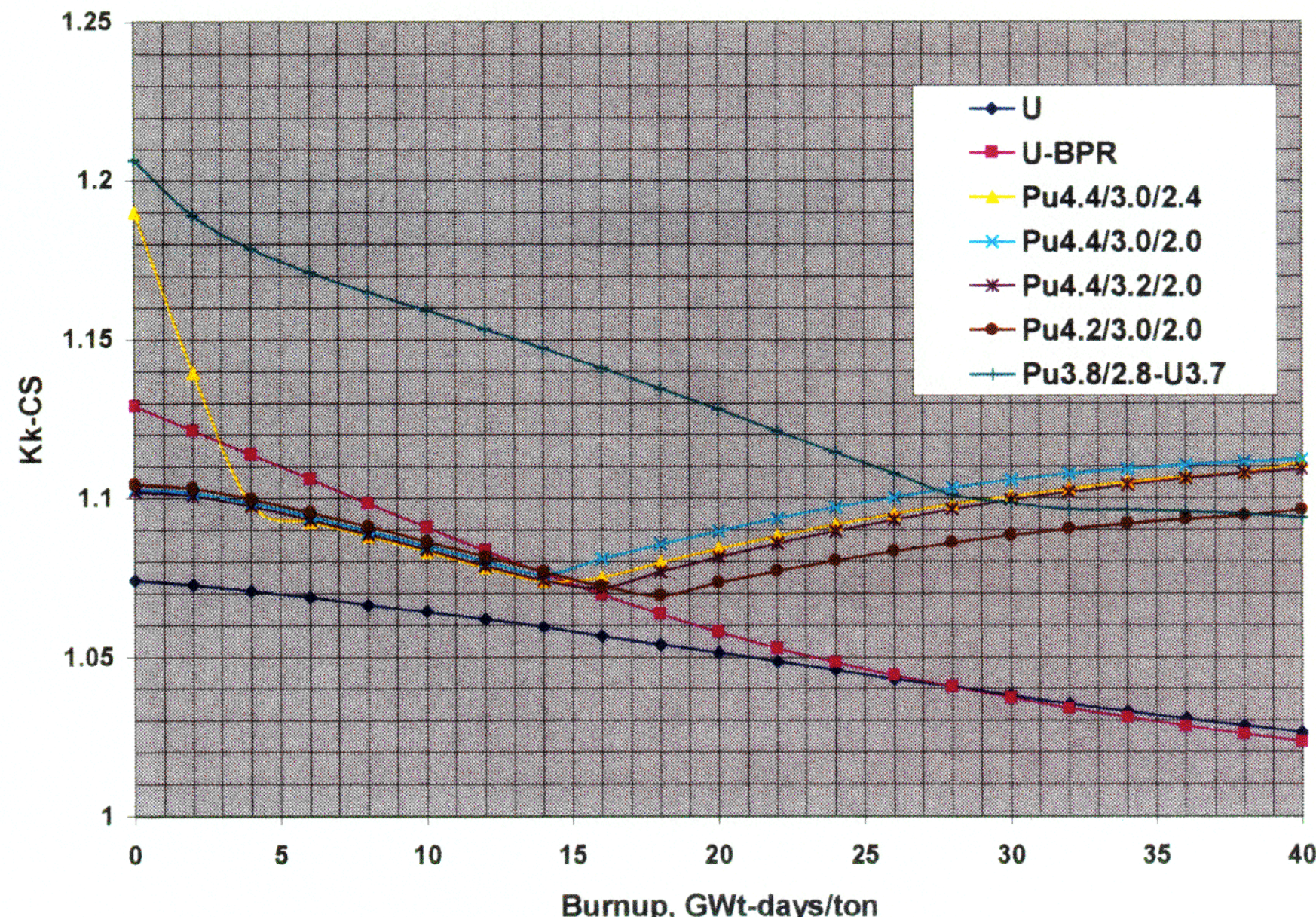

RRC KI. Design Studies of "Island" Type MOX Lead Test Assembly (Report for FY99) 


\section{Figure 2.14. Parametric Studies of "Island» Type MOX LTA}

$$
\text { (U 3.7\%) }
$$

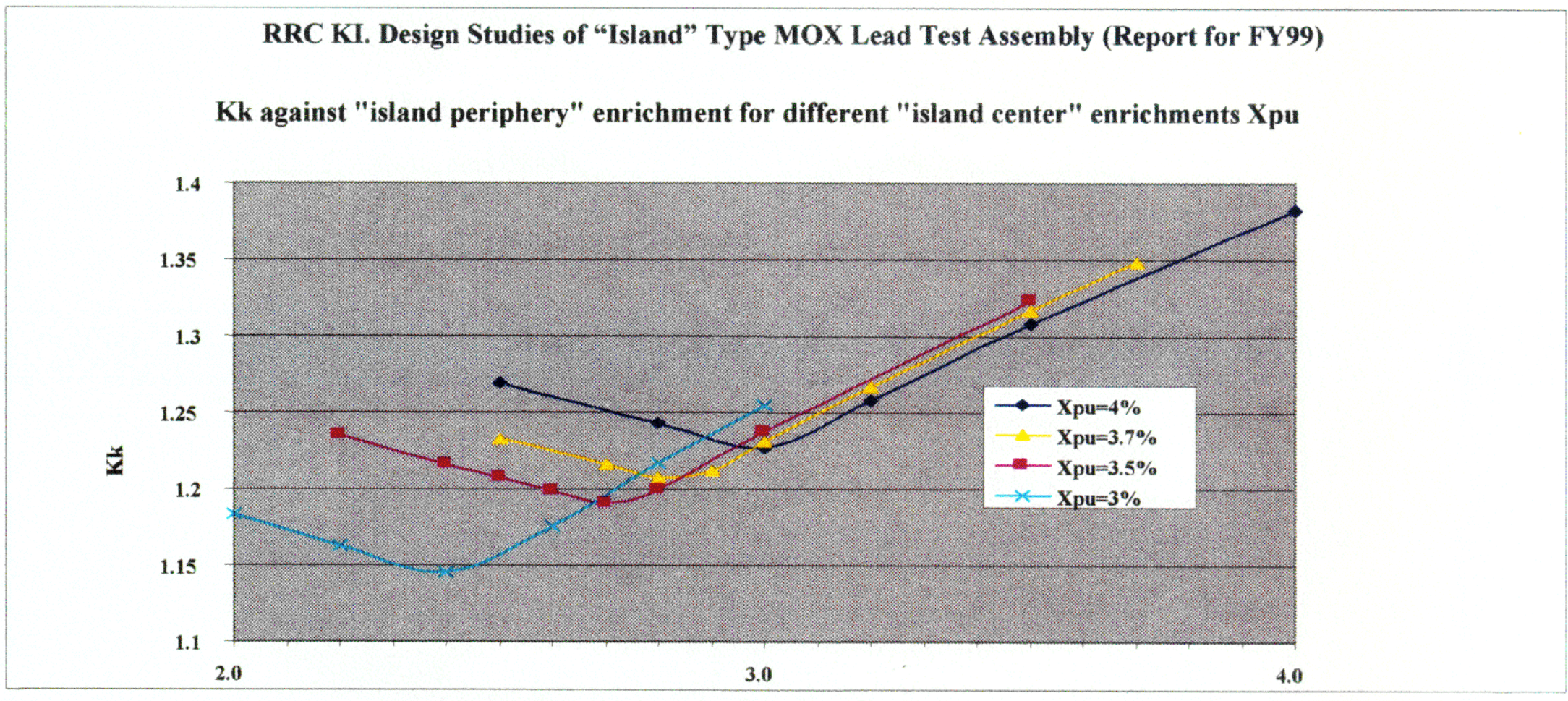

"Island periphery" enrichment of fissile Plutonium, \%

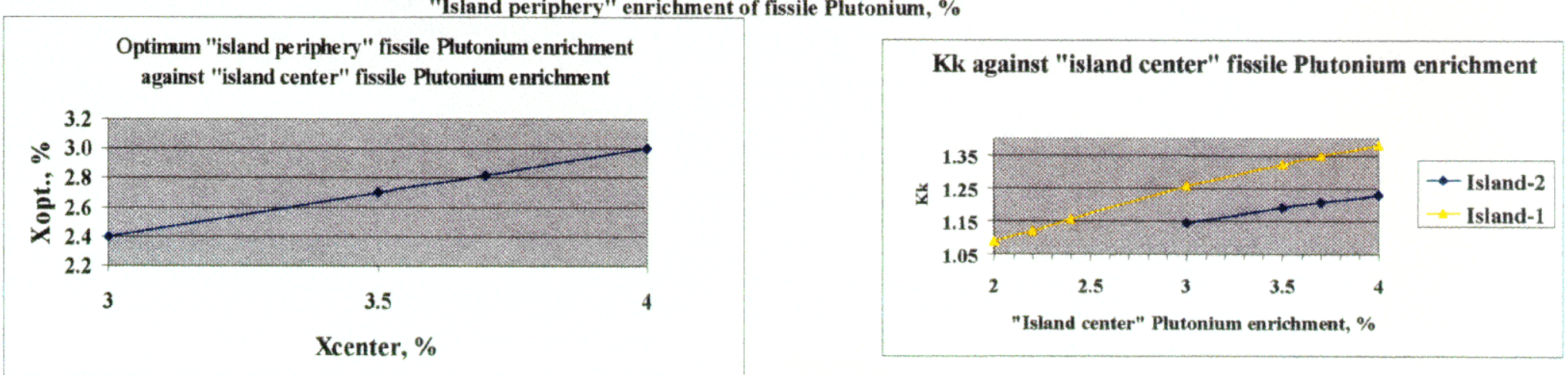




\section{Figure 2.15. Parametric Studies of "Island» Type MOX LTA (U 4.4\%)}
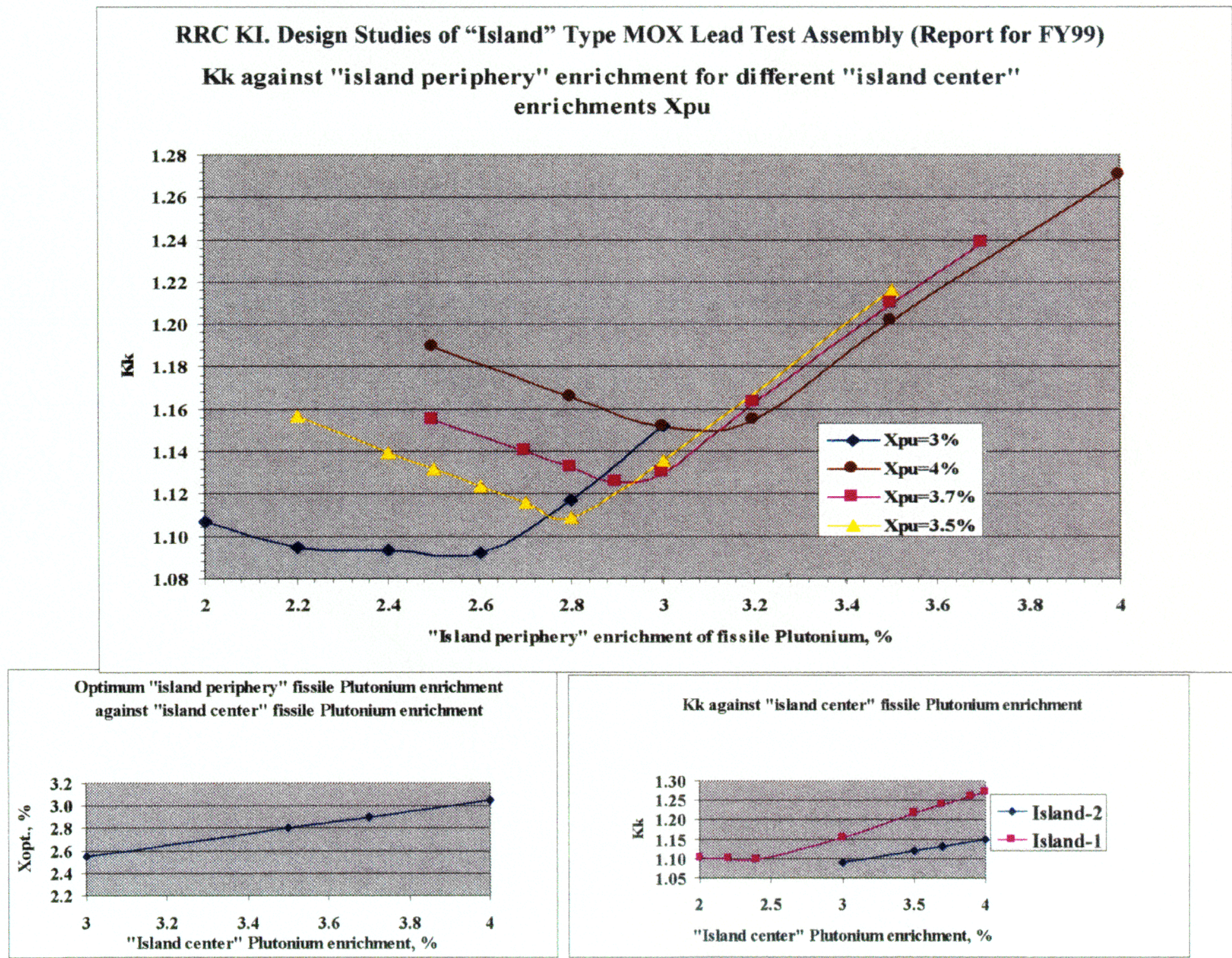

Kk against "island center" fissile Plutonium enrichment

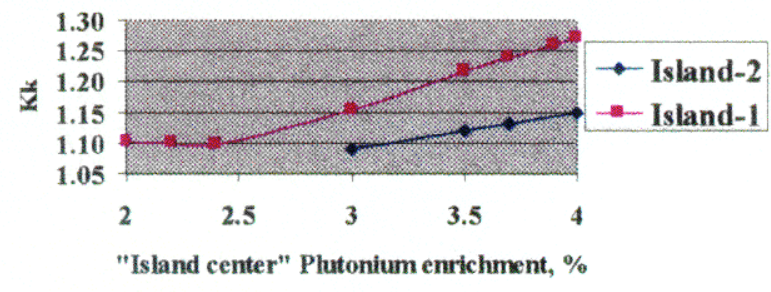




\section{Fig. 2.16. Kk versus Peripheral Plutonium Enrichment for Different}

Boron Concentrations. 3.7\%- Uranium Region Enrichment

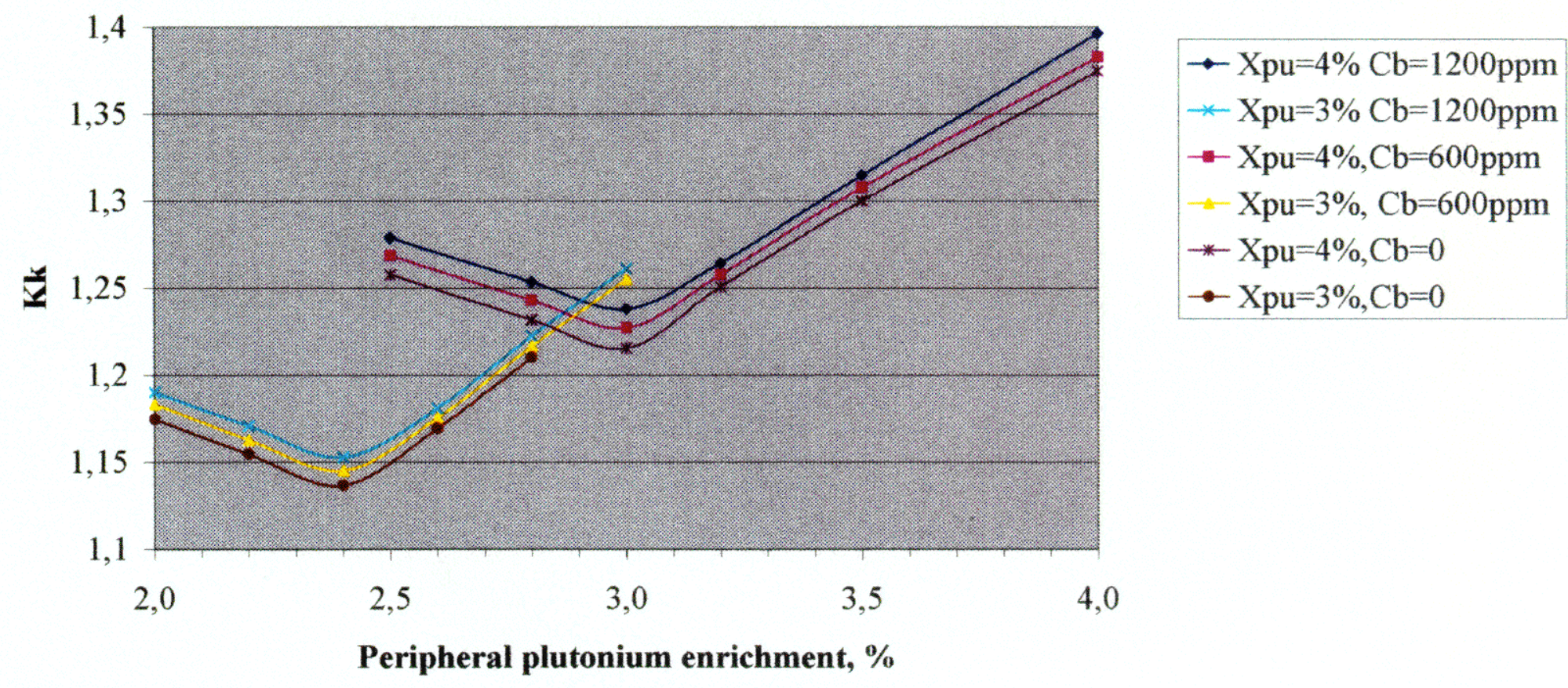


Fig. 2.17. Kk versus Peripheral Plutonium Enrichment for Different Boron Concentrations.

4.4\%- Uranium Region Enrichment

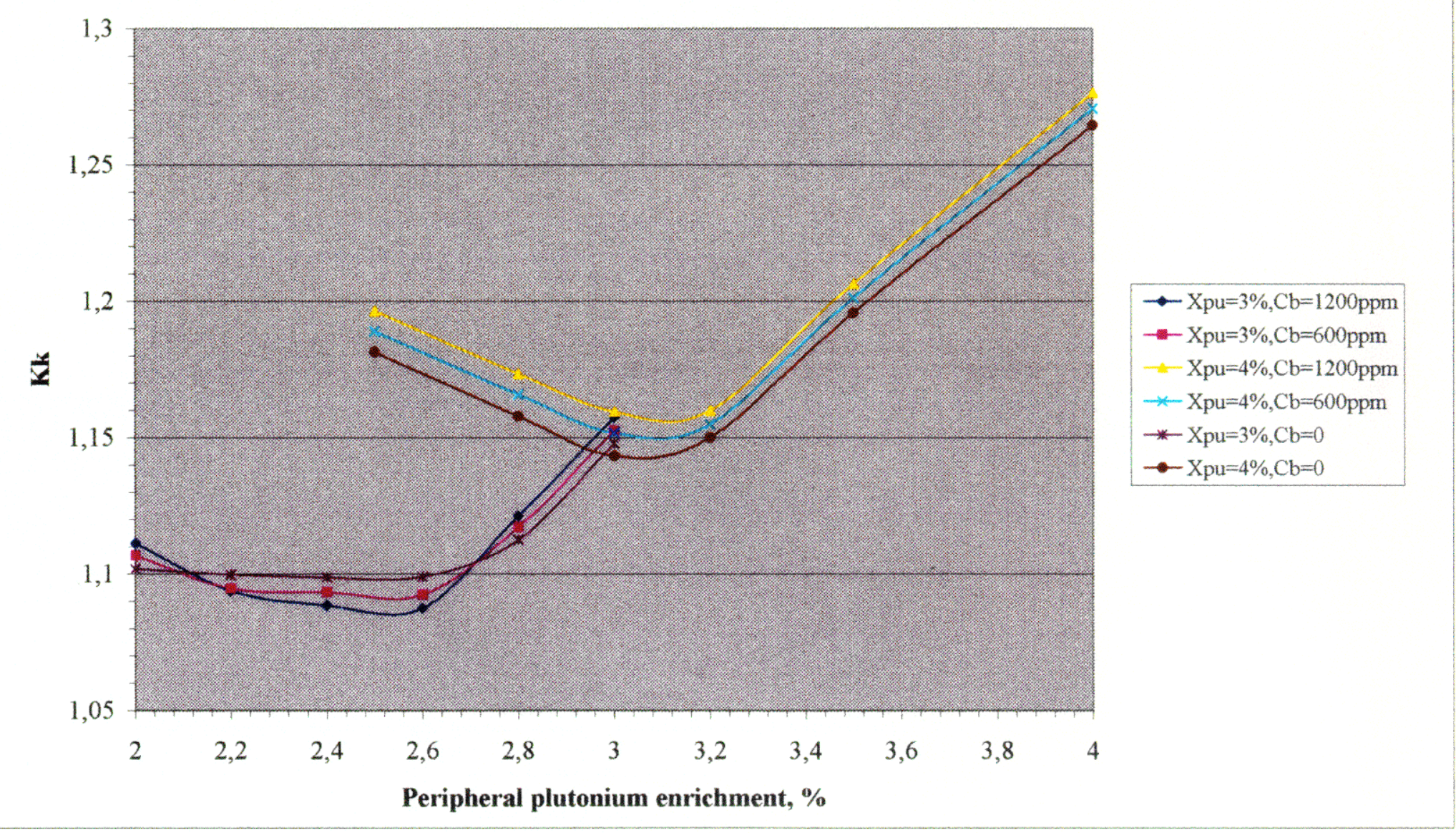



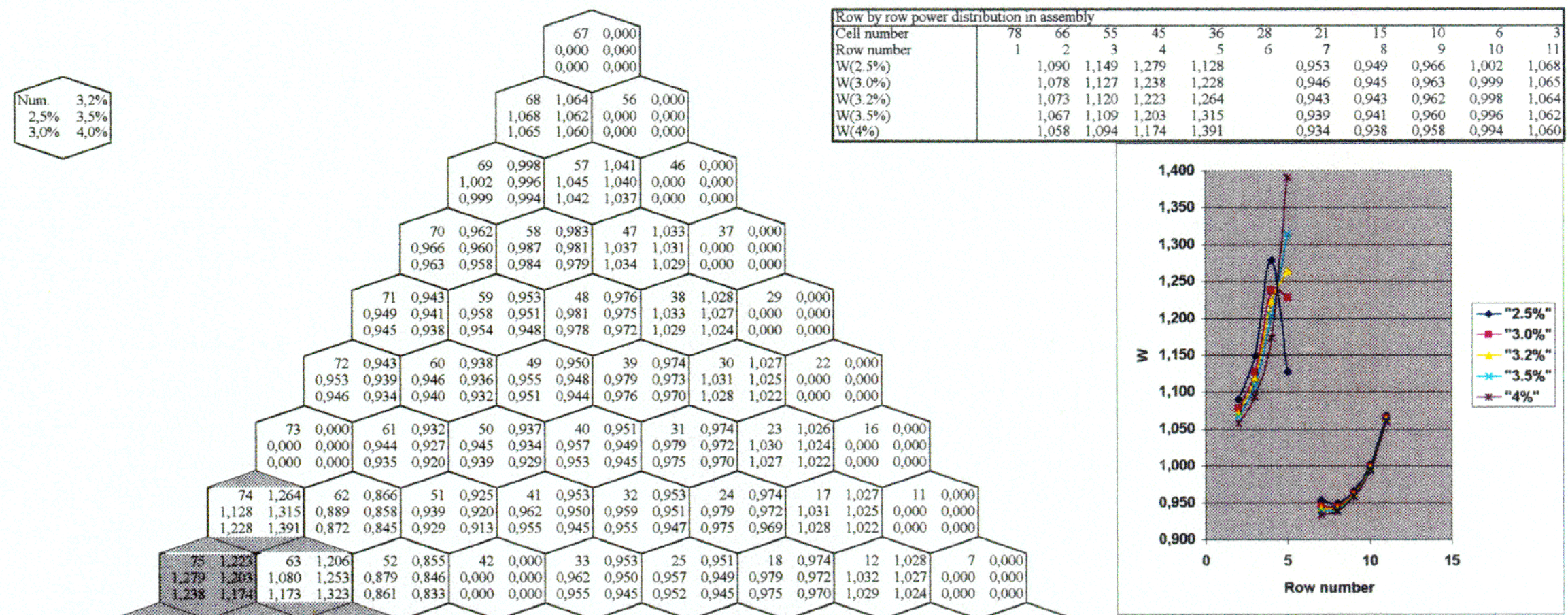

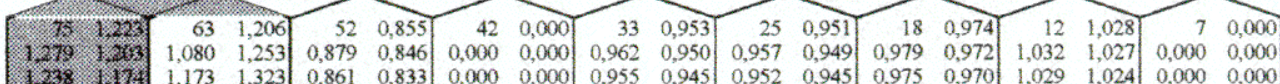

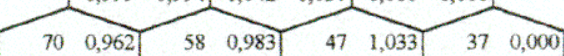

$\begin{array}{llllllllll}0,966 & 0,960 & 0,987 & 0,981 & 1,037 & 1,031 & 0,000 & 0,000 \\ 0,963 & 0,958 & 0,984 & 0,979 & 1,034 & 1,029 & 0,000 & 0,000 & 0\end{array}$

$\begin{array}{lllllllllll}71 & 0,943 & 59 & 0,953 & 48 & 0,976 & 38 & 1,028 & 29 & 0,000\end{array}$

\begin{tabular}{llllllllllll}
0,949 & 0,941 & 0,958 & 0,951 & 0,981 & 0,975 & 1,033 & 1,027 & 0,000 & 0,000 \\
\hline
\end{tabular}

$\begin{array}{llllllllllllllllllll}72 & 0,943 & 60 & 0,938 & 49 & 0,950 & 39 & 0,974 & 30 & 1,027 & 22 & 0,000\end{array}$

$\begin{array}{lllllllllllll}0,953 & 0,939 & 0,946 & 0,936 & 0,955 & 0,948 & 0,979 & 0,973 & 1,031 & 1,025 & 0,000 & 0,000 \\ 0,946 & 0,934 & 0,940 & 0,932 & 0,951 & 0,944 & 0,976 & 0,970 & 1,028 & 1,022 & 0,000 & 0,000\end{array}$

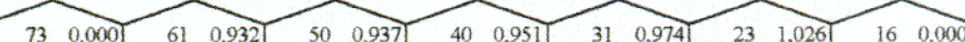

\begin{tabular}{|llll|lllllllll}
0,000 & 0,000 & 0,944 & 0,927 & 0,945 & 0,934 & 0,957 & 0,949 & 0,979 & 0,972 & 1,030 & 1,024 & $0,0,000$
\end{tabular}

$\begin{array}{llllllllllllll}0,000 & 0,000 & 0,935 & 0,920 & 0,939 & 0,929 & 0,953 & 0,945 & 0,975 & 0,970 & 1,027 & 1,022 & 0 & 0,0\end{array}$

\begin{tabular}{|lllllllllllllllllll}
74 & 1,264 & 62 & 0,866 & 51 & 0,925 & 41 & 0,953 & 32 & 0,953 & 24 & 0,974 & 17 & 1,027 & 11 & 0,000
\end{tabular}

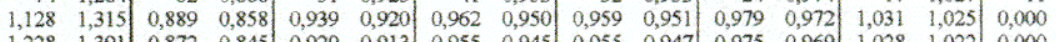

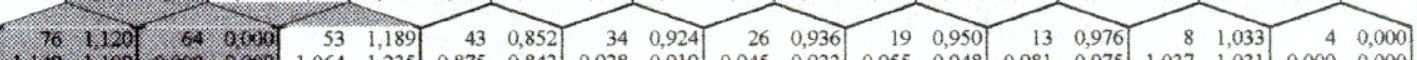

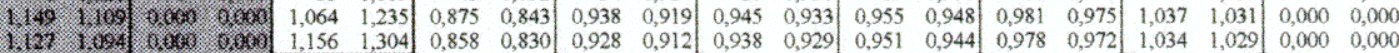

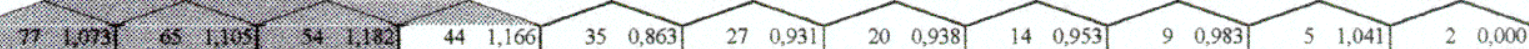

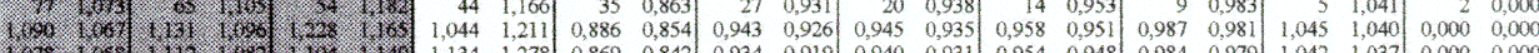

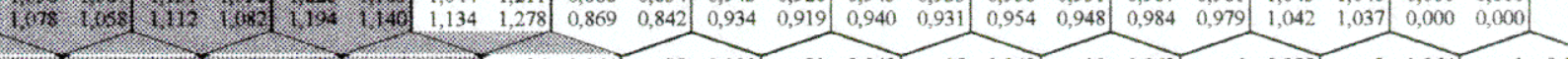

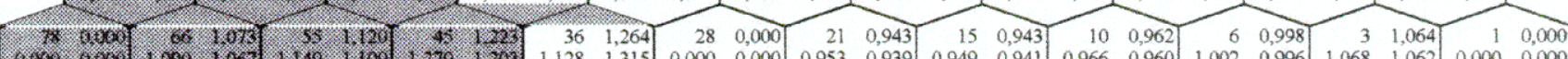

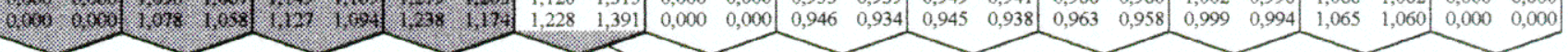

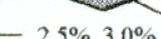

$-3.2 \%, 3.5 \%, 4.0 \%$ 

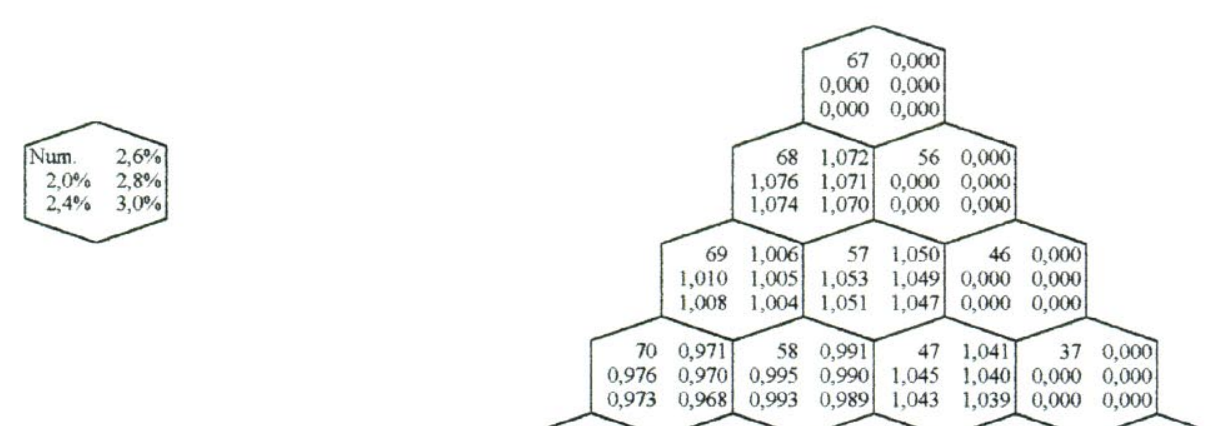

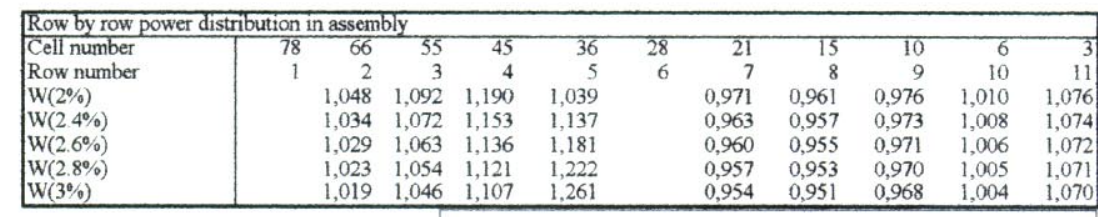

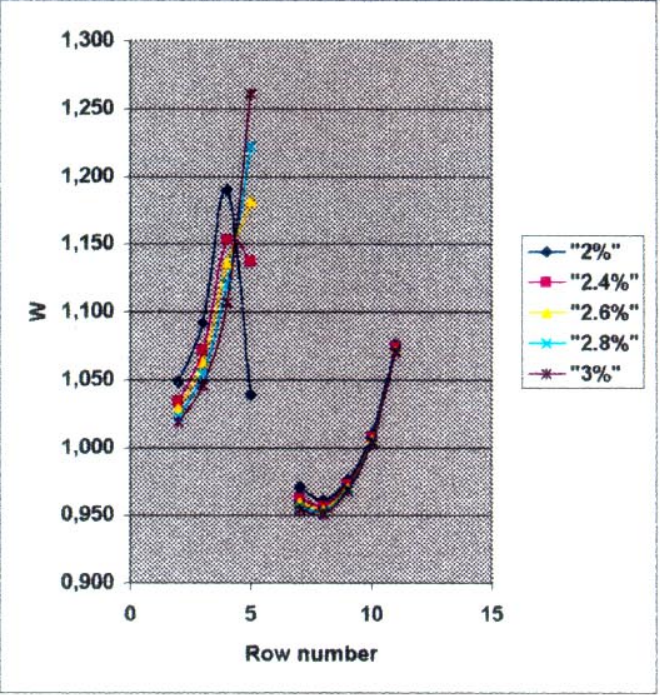

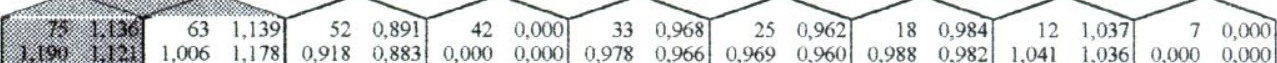

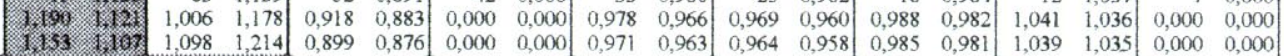

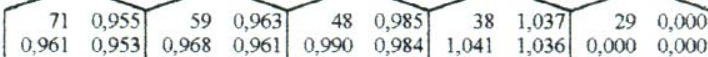

\begin{tabular}{|llll|lllllll|}
0,957 & 0,953 & 0,968 & 0,961 & 0,990 & 0,984 & 1,041 & 1,036 & 0,000 & 0,000 \\
0,965 & 0,960 & 0,987 & 0,983 & 1,039 & 1,035 & 0,000 & 0,000
\end{tabular}

$\begin{array}{lllllllllllllllll}72 & 0,960 & 60 & 0,951 & 49 & 0,960 & 39 & 0,984 & 30 & 1,036 & 22 & 0,000\end{array}$

$\begin{array}{lllllllllllllll}0,971 & 0,957 & 0,959 & 0,949 & 0,960 & 0,959 & 0,988 & 0,982 & 1,040 & 1,034 & 0,000 & 0,000 \\ 0,963 & 0,954 & 0,954 & 0,947 & 0,962 & 0,957 & 0,985 & 0,981 & 1,037 & 1,033 & 0,000 & 0,000\end{array}$

$\begin{array}{llllllllllllllllll}73 & 0,000 & 61 & 0,952 & 50 & 0,951 & 40 & 0,962 & 31 & 0,984 & 23 & 1,035 & 16 & 0,000\end{array}$

$\begin{array}{llllllllllllllll}0,000 & 0,000 & 0,966 & 0,948 & 0,960 & 0,948 & 0,969 & 0,960 & 0,989 & 0,982 & 1,039 & 1,034 & 0,000 & 0,000\end{array}$

\begin{tabular}{|llllllllllllllllll}
74 & 1,181 & 62 & 0,900 & 51 & 0,948 & 41 & 0,969 & 32 & 0,964 & 24 & 0,984 & 17 & 1,036 & 11 & 0,000
\end{tabular}

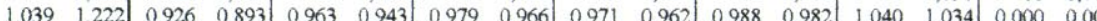

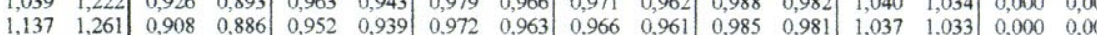

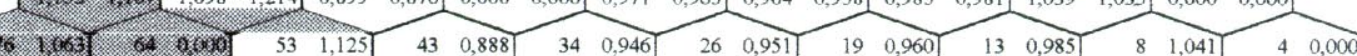

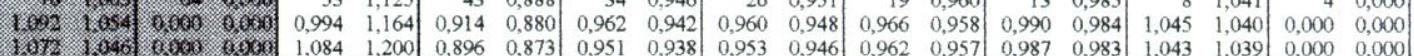

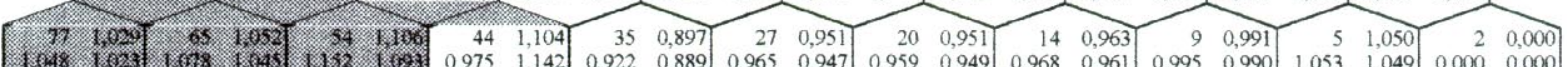

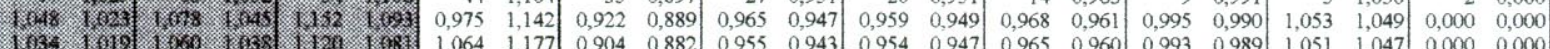

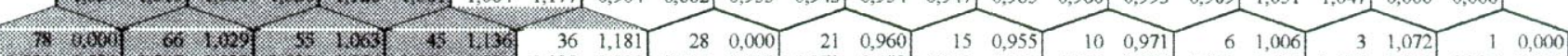

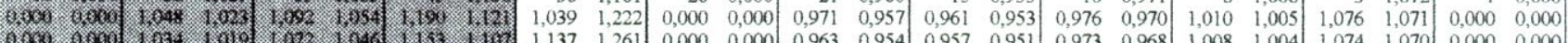

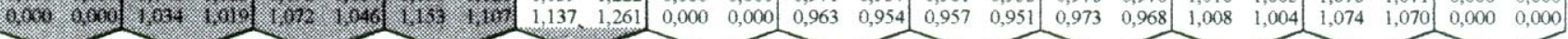

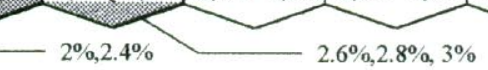




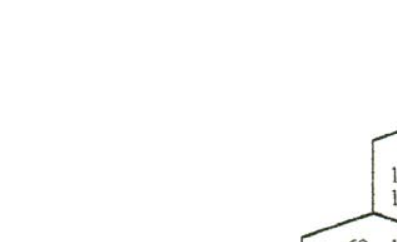

$$
670,000
$$
$0,000-0,000$ $\begin{array}{ll}0,000 & 0,000 \\ 0,000 & 0,000\end{array}$

$1,080756 \quad 0,000$ \begin{tabular}{ll|ll}
1,084 & 1,079 & 0,000 & 0,000 \\
0,081 & 1,077 & 0,000 & 0,000
\end{tabular}

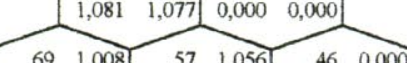
$\begin{array}{llllll}1,012 & 1,007 & 1,059 & 1,055 & 0,000 & 0,000\end{array}$ $\begin{array}{lllllll}1,009 & 1,005 & 1,057 & 1,053 & 0,000 & 0,000\end{array}$ $\begin{array}{lllllllll}70 & 0,971 & 58 & 0,993 & 47 & 1,047 & 37 & 0,000\end{array}$ $\begin{array}{llllllllll}0,975 & 0,970 & 0,996 & 0,991 & 1,051 & 1,046 & 0,000 & 0,000\end{array}$ $\begin{array}{llllllllll}0,973 & 0,968 & 0,994 & 0,989 & 1,048 & 1,044 & 0,000 & 0,000\end{array}$ \begin{tabular}{|ll|ll|lll|lll|l}
71 & 0,955 & 59 & 0,963 & 48 & 0,987 & 38 & 1,043 & 29 & 0,000
\end{tabular} $\begin{array}{lllllllllll}0,956 & 0,950 & 0,964 & 0,959 & 0,988 & 0,983 & 1,044 & 1,039 & 0,000 & 0,000\end{array}$

$\begin{array}{lllllllllllllllll}72 & 0,962 & 60 & 0,952 & 49 & 0,961 & 39 & 0,985 & 30 & 1,041 & 22 & 0,000\end{array}$ \begin{tabular}{llllllllllll|lll}
0,972 & 0,959 & 0,959 & 0,949 & 0,966 & 0,959 & 0,989 & 0,984 & 1,045 & 1,040 & 0,000 & 0,000
\end{tabular} (0.000 0,000 $\begin{array}{lllllllllllllllllll}73 & 0,000 & 61 & 0,954 & 50 & 0,952 & 40 & 0,963 & 31 & 0,985 & 23 & 1,041 & 16 & 0,000\end{array}$

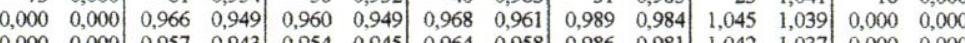
$\begin{array}{lllllllllllllll}0,000 & 0,000 & 0,957 & 0,943 & 0,954 & 0,945 & 0,964 & 0,958 & 0,986 & 0,981 & 1,042 & 1,037 & 0,000 & 0,000\end{array}$ \begin{tabular}{|lllllllllllllllll}
74 & 1,160 & 62 & 0,899 & 51 & 0,950 & 41 & 0,971 & 32 & 0,965 & 24 & 0,985 & 17 & 1,041 & 11 & 0,000
\end{tabular} \begin{tabular}{lllllll|lllll|lllllll}
1,034 & 1,206 & 0,923 & 0,891 & 0,963 & 0,945 & 0,980 & 0,968 & 0,971 & 0,963 & 0,989 & 0,984 & 1,045 & 1,040 & 0,000 & 0,000 &
\end{tabular} $\begin{array}{lllllllllllllllllllllll}15 & 1.146 & 63 & 1,114 & 52 & 0,889 & 42 & 0,000 & 33 & 0,971 & 25 & 0,963 & 18 & 0,985 & 12 & 1,043 & 7 & 0,000\end{array}$ \begin{tabular}{lllllllllllllllllll}
1.196 & 1,28 & 0,997 & 1,158 & 0,914 & 0,881 & 0,000 & 0,000 & 0,980 & 0,968 & 0,968 & 0,961 & 0,989 & 0,983 & 1,047 & 1,041 & 0,000 & 0,000 \\
\hline
\end{tabular} $\begin{array}{llllllllllllllllll}1.79 & 1,1028 & 1,083 & 1,223 & 0,896 & 0,868 & 0,000 & 0,000 & 0,974 & 0,963 & 0,964 & 0,958 & 0,986 & 0,981 & 1,044 & 1,039 & 0,000 & 0,000\end{array}$

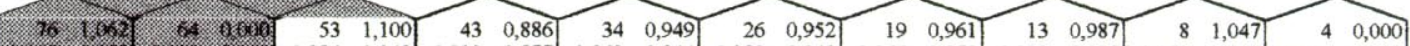

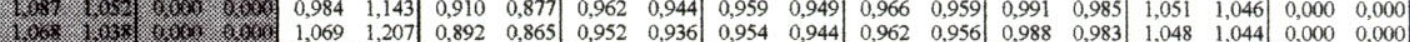

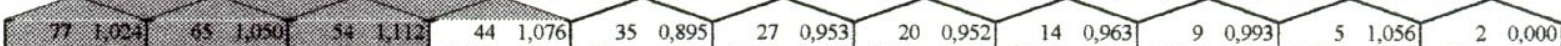

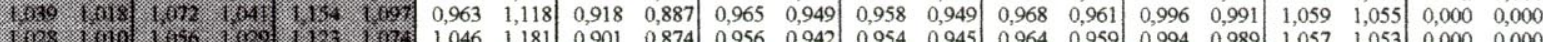

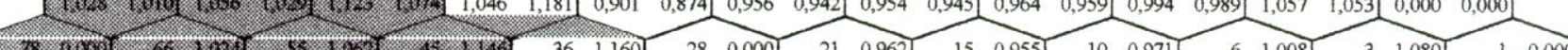

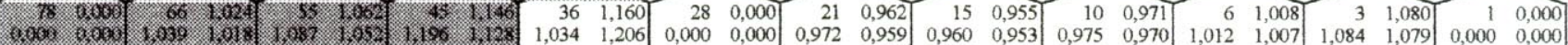

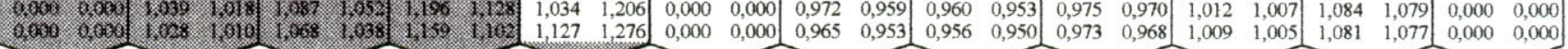

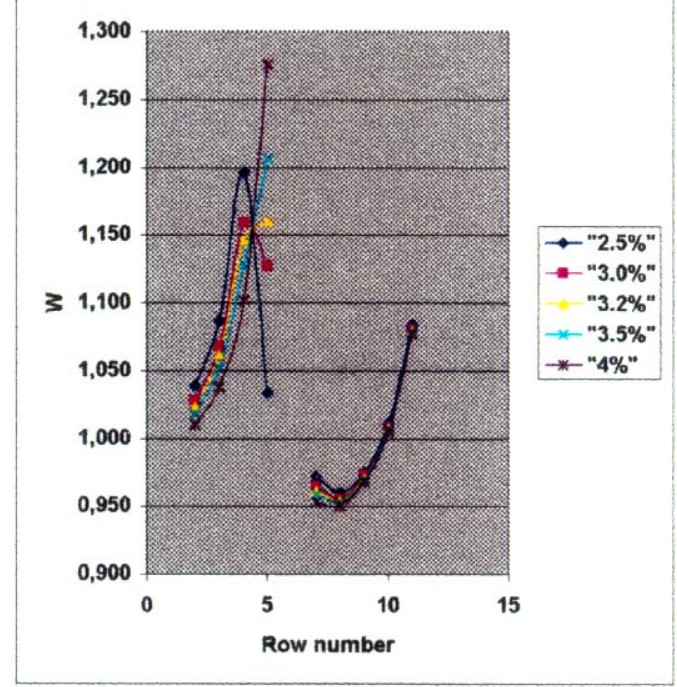

$-2.5 \%, 3.0 \%$

$3.2 \%, 3.5 \%, 4.0 \%$ 


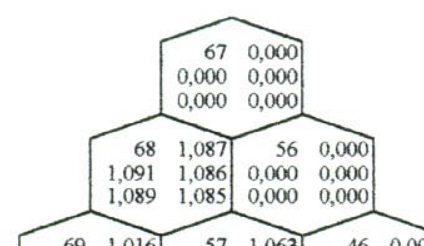

\begin{tabular}{rr|rr|rr}
69 & 1,016 & 57 & 1,063 & 46 & 0,000
\end{tabular}

\begin{tabular}{llll|lll}
1,019 & 1,015 & 1,067 & 1,062 & 0,000 & 0,000 \\
1,017 & 1,014 & 1,064 & 1,061 & 0,000 & 0,000
\end{tabular}

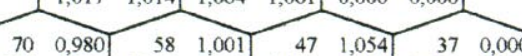

$\begin{array}{lllllllll}0,984 & 0,979 & 1,004 & 0,999 & 1,058 & 1,053 & 0,000 & 0,000\end{array}$

\begin{tabular}{ll|ll|lllll}
0,981 & 0,977 & 1,002 & 0,998 & 1,056 & 1,052 & 0,000 & 0,000 \\
\hline
\end{tabular}

\begin{tabular}{rr|rrr|rr|rrr}
71 & 0,966 & 59 & 0,972 & 48 & 0,995 & 38 & 1,050 & 29 & 0,000
\end{tabular}

$\begin{array}{lllllllllll}0,967 & 0,962 & 0,974 & 0,970 & 0,996 & 0,993 & 1,052 & 1,048 & 0,000 & 0,000 & 0\end{array}$

$\begin{array}{lllllllllllllllll}72 & 0,979 & 60 & 0,964 & 49 & 0,971 & 39 & 0,994 & 30 & 1,049 & 22 & 0,000\end{array}$

$\begin{array}{llllllllllllll}0,989 & 0,975 & 0,972 & 0,962 & 0,976 & 0,969 & 0,998 & 0,992 & 1,053 & 1,048 & 0,000 & 0,000\end{array}$

0,982 (2,

$\begin{array}{lllllllllllllllll}73 & 0,000 & 61 & 0,974 & 50 & 0,966 & 40 & 0,974 & 31 & 0,994 & 23 & 1,049 & 16 & 0,000\end{array}$

\begin{tabular}{llll|llll|lll|ll|ll}
0,000 & 0,000 & 0,987 & 0,970 & 0,974 & 0,963 & 0,979 & 0,972 & 0,998 & 0,992 & 1,053 & 1,047 & 0,000 & 0,000
\end{tabular}

$\begin{array}{llllllllllllllll}0,000 & 0,000 & 0,978 & 0,966 & 0,968 & 0,961 & 0,975 & 0,970 & 0,995 & 0,991 & 1,050 & 1,046 & 0,000 & 0,000\end{array}$

$\begin{array}{lllllllllllllllllll}74 & 1,083 & 62 & 0,934 & 51 & 0,972 & 41 & 0,987 & 32 & 0,976 & 24 & 0,994 & 17 & 1,049 & 11 & 0,000\end{array}$

$\begin{array}{llllllllllllllllll}0,952 & 1,121 & 0,960 & 0,926 & 0,987 & 0,968 & 0,996 & 0,984 & 0,982 & 0,974 & 0,998 & 0,992 & 1,053 & 1,048 & 0,000 & 0,000\end{array}$

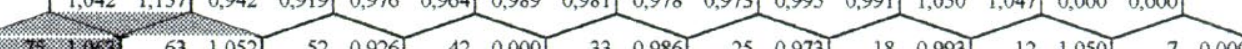

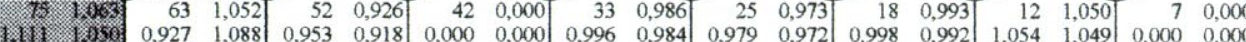

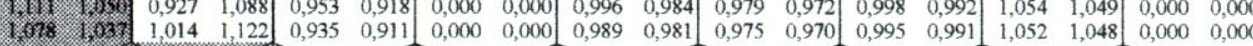

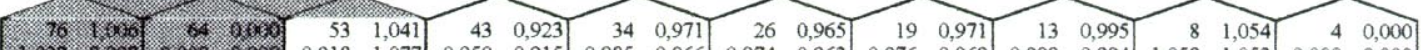

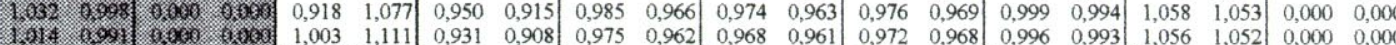

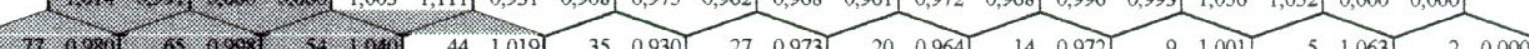

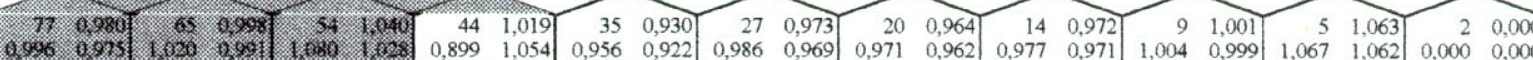

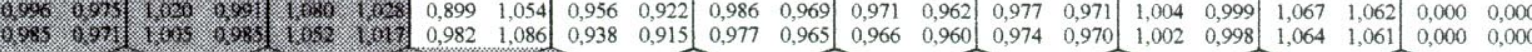

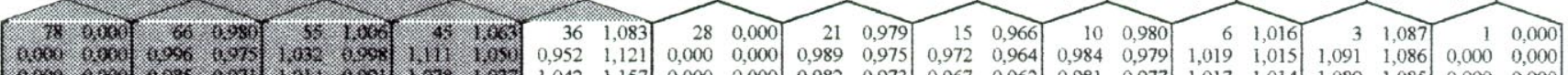

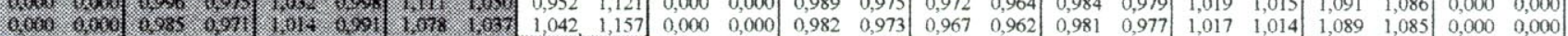

$$
{ }_{2 \%} L_{2.8 \%, 3 \%}{ }_{2.4 \%, 2.6 \%}
$$


Fig. 2.22. Comparison of Power Inter-assembly Distributions in "Island-2" of Optimum Grading. 3\% Plutonium Central Part with 3.7\% and 4.4\% Uranium Regions
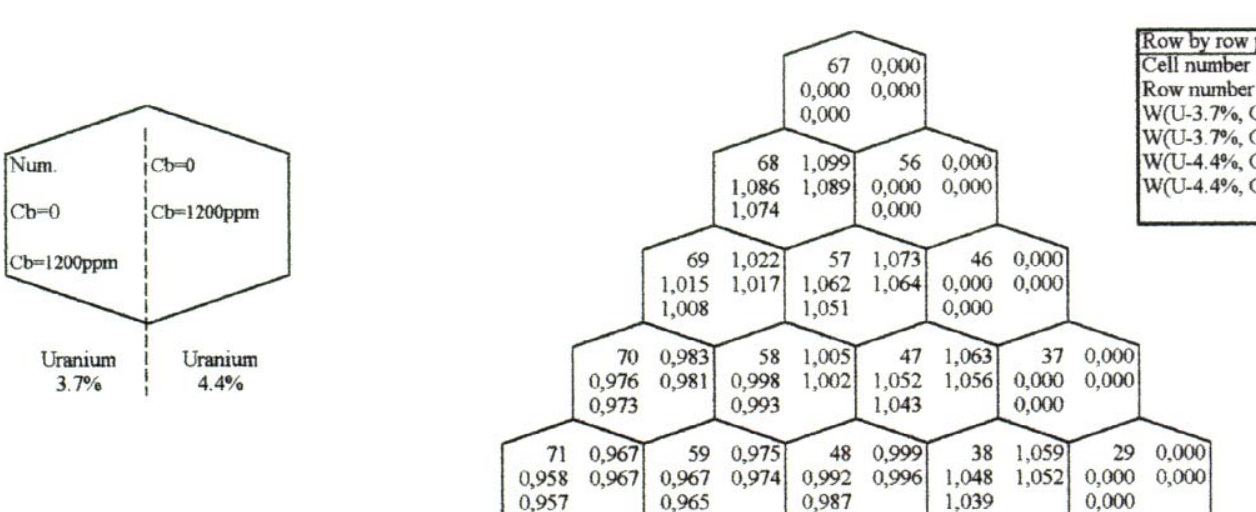

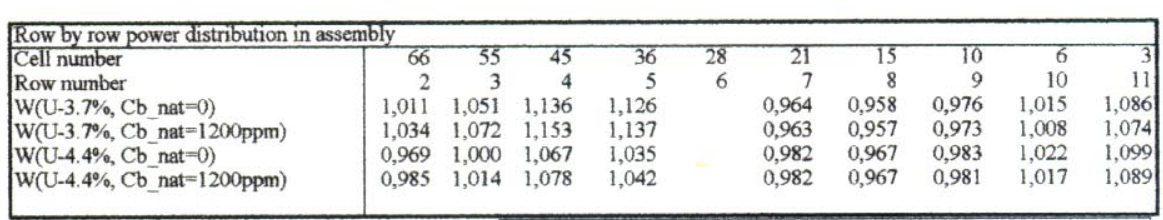

$\begin{array}{lllllllllllll}72 & 0.982 & 60 & 0.966 & 49 & 0,973 & 39 & 0,997 & 30 & 1,057 & 22 & 0,000\end{array}$ \begin{tabular}{llll|llll|lll|l}
0,964 & 0,982 & 0,954 & 0,967 & 0,964 & 0,972 & 0,989 & 0,995 & 1,046 & 1,050 & 0,000 & 0,000 \\
\hline
\end{tabular}

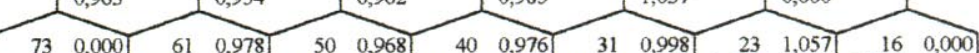

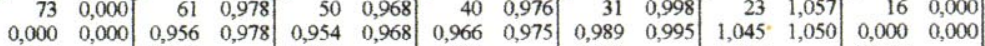
0,000 $\begin{array}{llllllllllllllllll}74 & 1,035 & 62 & 0,941 & 51 & 0,976 & 41 & 0,990 & 32 & 0,979 & 24 & 0,998 & 17 & 1,057 & 11 & 0,000\end{array}$

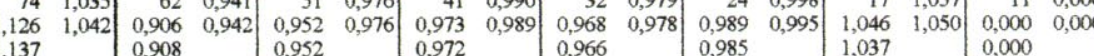
137 $952\left[\begin{array}{l}0,972 \\ 0,973\end{array}\right.$

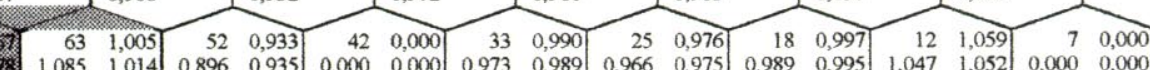
\begin{tabular}{ll|ll|ll|l}
1.136 & 1.078 & 1,085 & 1,014 & 0,896 & 0,935 & 0,000 \\
1,098 & 0,899 & 0,000 & 0
\end{tabular}

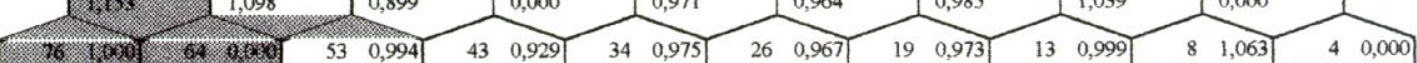

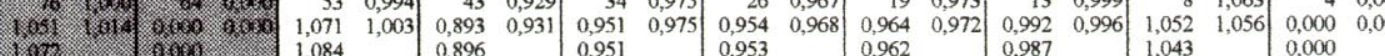

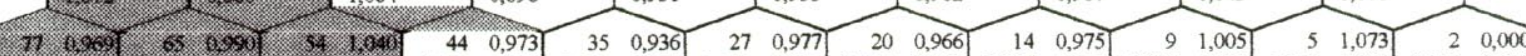

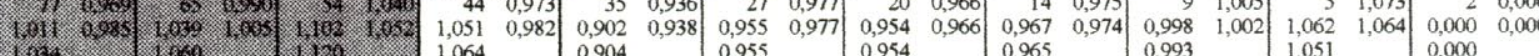

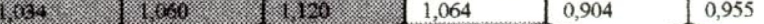

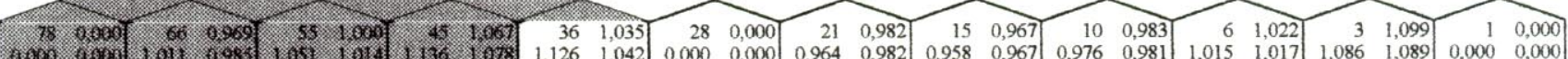

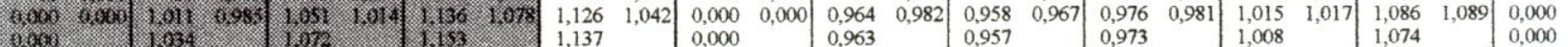
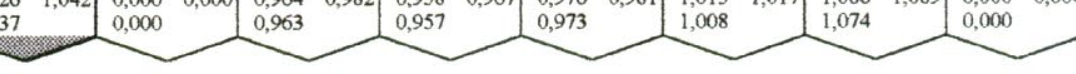
Fig. 2.23. Comparison of Power Inter-assembly Distributions in "Island-2" of Optimum Grading. 4\% Plutonium Central Part with 3.7\% and 4.4\% Uranium Regions
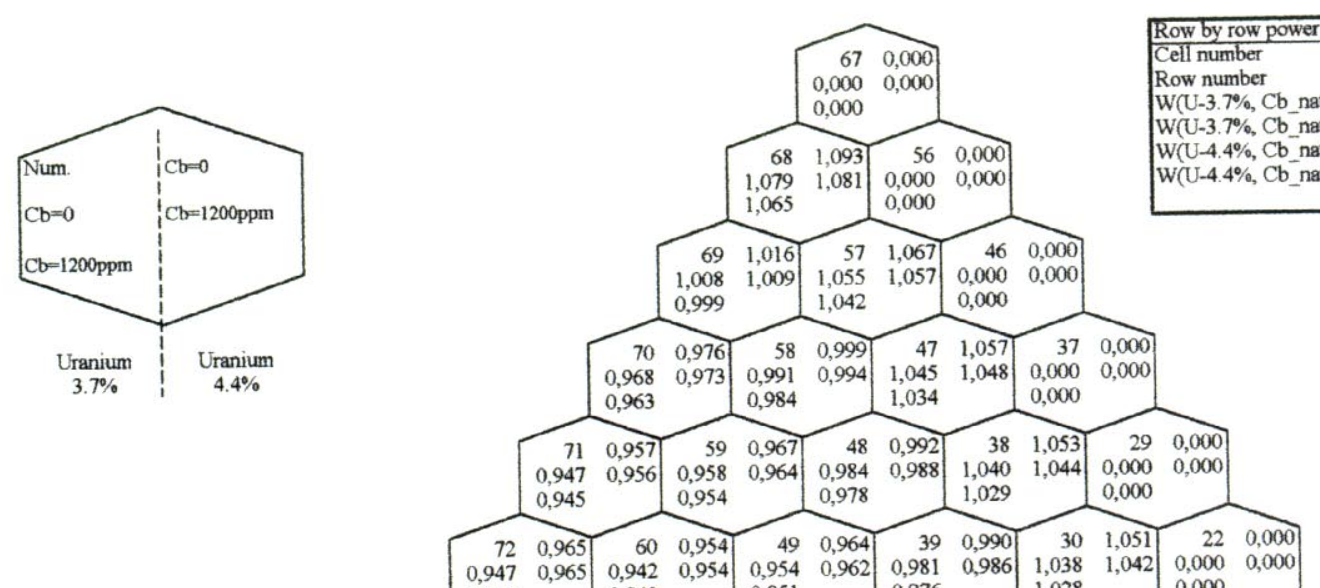

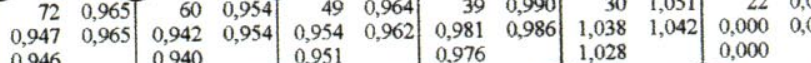

$\begin{array}{lllllllllllllllll}73 & 0,000 & 61 & 0,957 & 50 & 0,954 & 40 & 0,966 & 31 & 0,990 & 23 & 1,050 & 16 & 0,000\end{array}$

\begin{tabular}{lllllllll|lllllll}
0,000 & 0,000 & 0,935 & 0,957 & 0,940 & 0,954 & 0,956 & 0,964 & 0,981 & 0,986 & 1,037 & 1,042 & 0,000 & 0,000
\end{tabular}

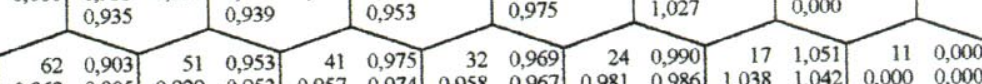

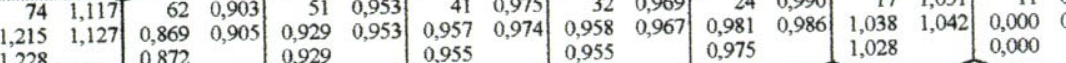

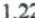

0,872

$0,929 \quad 0,955$

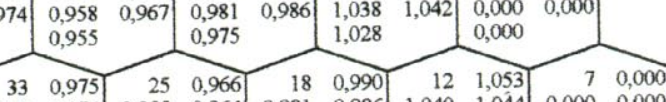

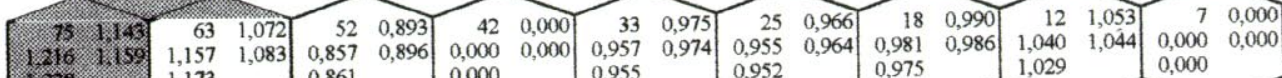

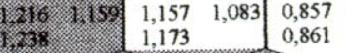

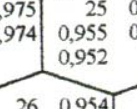

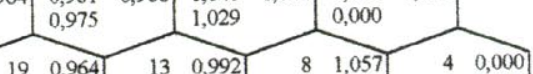

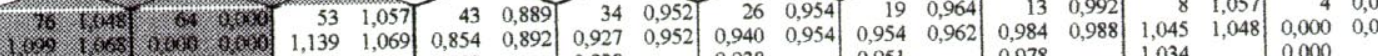

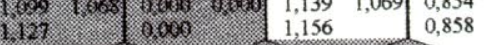

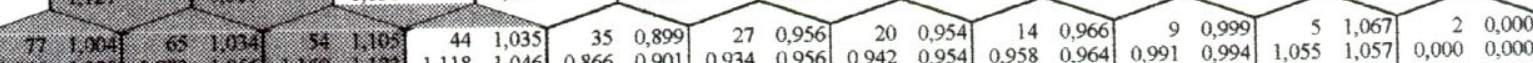

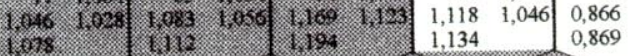

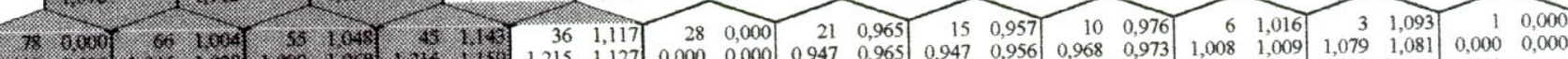


Fig. 2.24. Comparison of Power Inter-assembly Distributions in "Island-1". 3\% Plutonium Central Part with 3.7\% and 4.4\% Uranium Regions
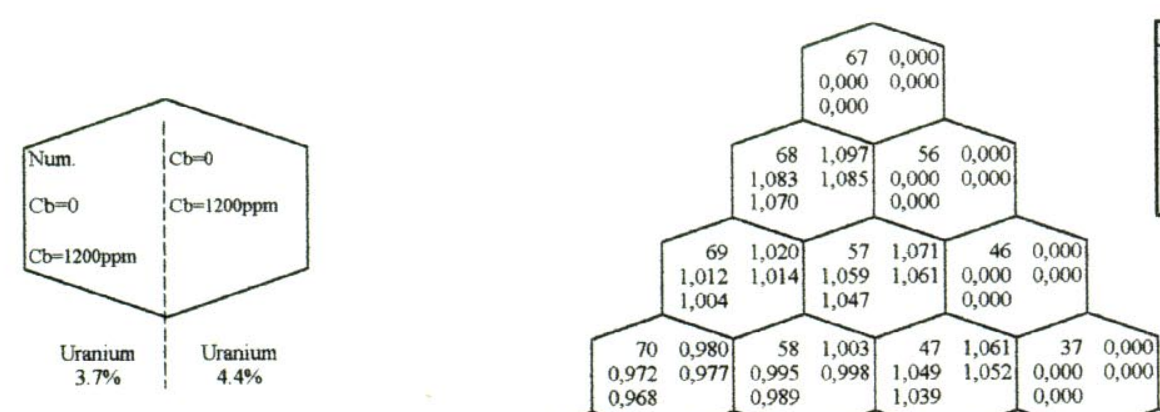

\begin{tabular}{|c|c|c|c|c|c|c|c|c|c|c|}
\hline$\frac{\text { Row by row power distribution }}{\text { Cell number }}$ & 156 & & & & & & 15 & 10 & 6 & \\
\hline Row number & 2 & 3 & 4 & 5 & 6 & 7 & 8 & 9 & 10 & \\
\hline$W(\mathrm{U}-3.7 \%, \mathrm{Cb}$ nat $=0)$ & 0,994 & 1,025 & 1,089 & 1,248 & & 0,954 & 0,952 & 0,972 & 1,012 & \\
\hline W(U-3.7\%, Cb nat $=1200 \mathrm{ppm})$ & 1,019 & 1,046 & 1,107 & 1,261 & & 0,954 & 0,951 & 0,968 & 1,004 & \\
\hline W(U-4.4\%, Cb nat $=0)$ & 0,953 & 0.976 & 1,025 & 1,148 & & 0,972 & 0,962 & 0,980 & & \\
\hline $\mathrm{W}(\mathrm{U}-4.4 \%, \mathrm{Cb}$ nat $=1200 \mathrm{ppm})$ & 0,971 & 0,991 & 1,037 & 1,157 & & 0,973 & 0,962 & 0,977 & 1,014 & 1,085 \\
\hline
\end{tabular}

$\mathrm{W}(\mathrm{U}-4.4 \%, \mathrm{Cb}$ nat $=0)$
$\mathrm{W}(\mathrm{U}-4.4 \%, \mathrm{Cb}$ nat $=1200 \mathrm{ppm})$

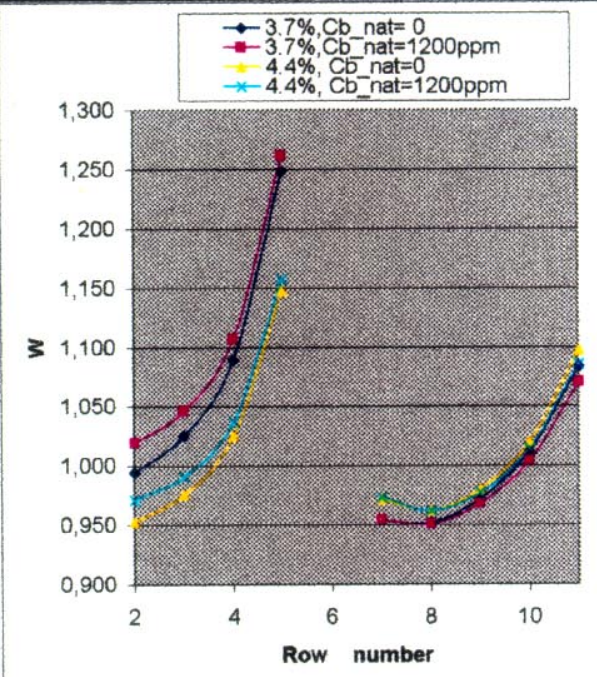

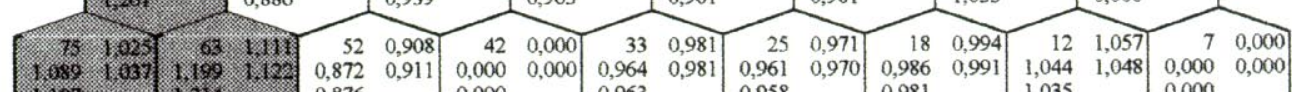
$\begin{array}{llllllllll}71 & 0,962 & 59 & 0,971 & 48 & 0,996 & 38 & 1,057 & 29 & 0,000\end{array}$ \begin{tabular}{ll|lll}
0,952 & 0,962 & 0,963 \\
0,951 & 0,960 & 0 & 0 \\
\hline
\end{tabular}

$\begin{array}{lllllllllllllll}72 & 0,972 & 60 & 0,960 & 49 & 0,968 & 39 & 0,994 & 30 & 1,055 & 22 & 0,000\end{array}$ $\begin{array}{llllllllllllll}0,954 & 0,973 & 0,948 & 0,960 & 0,959 & 0,968 & 0,986 & 0,991 & 1,042 & 1,047 & 0,000 & 0,000\end{array}$

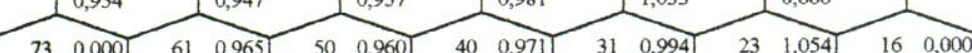
0,000

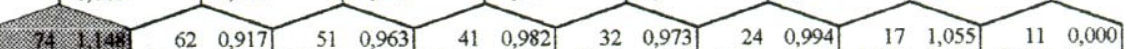

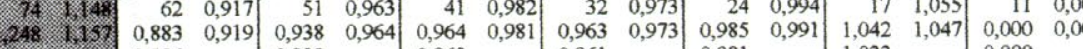
$1.107: 1,121 \%: 0.876$

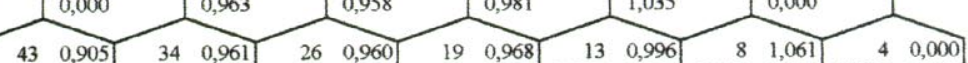

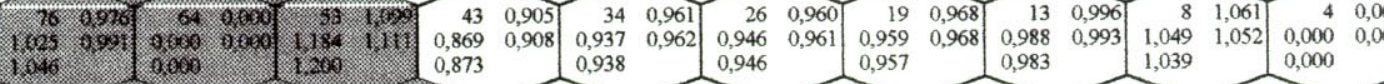

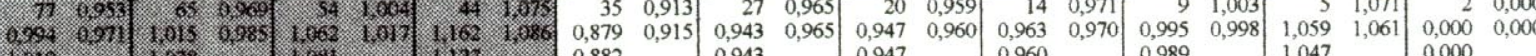

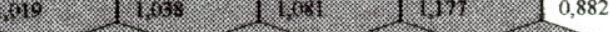

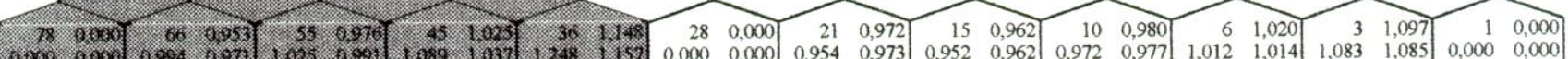

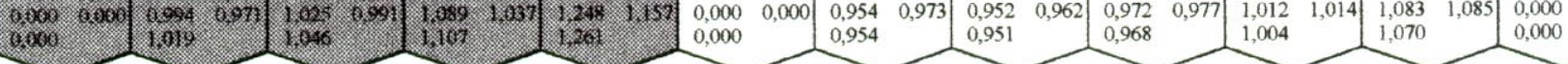
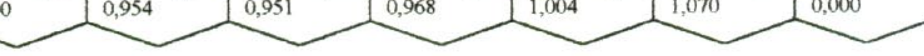
Fig. 2.25. Comparison of Power Inter-assembly Distributions in "Island-1". 4\% Plutonium Central Part with 3.7\% and 4.4\% Uranium Regions
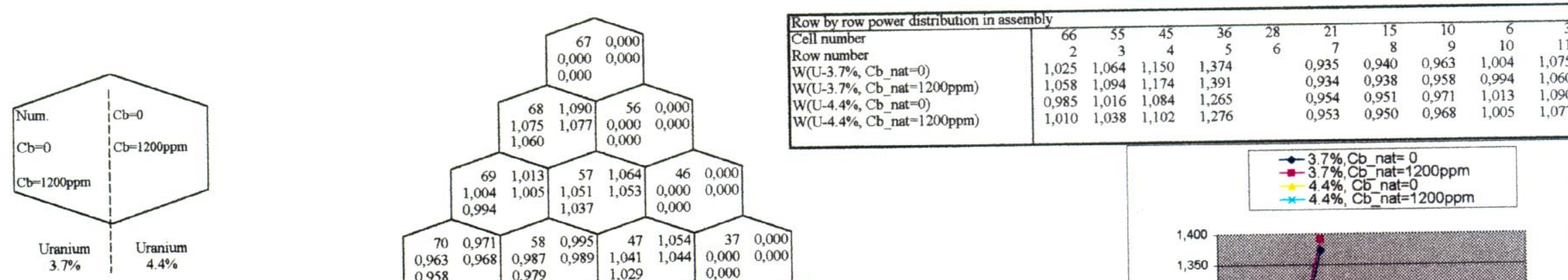

\begin{tabular}{rr|rr|rr}
69 & 1,013 & 57 & 1,064 & 46 & 0,000 \\
1,004 & 1,005 & 1,051 & 1,053 & 0,000 & 0,000 \\
0 & 1,037 & & 0,000 & \\
\hline
\end{tabular}

0,994

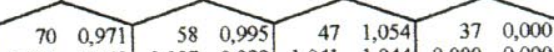

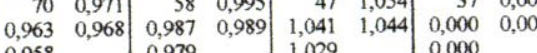

$\begin{array}{l:c}3.7 \% & 4.4 \% \\ & \end{array}$

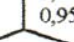

0,987 (0,989

$\underbrace{1,029}_{0,989} \underbrace{1,044}_{38,1,049} \begin{array}{lll}0,000 \\ 0,000\end{array}$

$\begin{array}{ll}29 & 0,000 \\ 0,000 & 0,000\end{array}$

\begin{tabular}{lllllll|ll|ll}
0,940 & 0,950 & 0,953 & 0,959 & 0,979 & 0,983 & 1,036 & 1,039 & 0,000 & 0,000
\end{tabular}

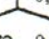

0,948

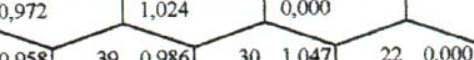

\begin{tabular}{|rr|rr|rr|rr|rr|rr|}
\hline 72 & 0,954 & 60 & 0,946 & 49 & 0,958 & 39 & 0,986 & 30 & 1,047 & 22 & 0,000 \\
0.935 & 0,953 & 0,933 & 0,946 & 0,948 & 0,956 & 0,976 & 0,981 & 1,034 & 1,038 & 0,000 & 0,000
\end{tabular}

0,934

$\begin{array}{llllllll}0,932 & 0,944, & 0,970 & 1,022 & 0,000\end{array}$

$\begin{array}{lllllllllllllll}73 & 0,000 & 61 & 0,943 & 50 & 0,945 & 40 & 0,960 & 31 & 0,986 & 23 & 1,046 & 16 & 0,000\end{array}$

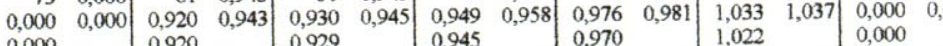

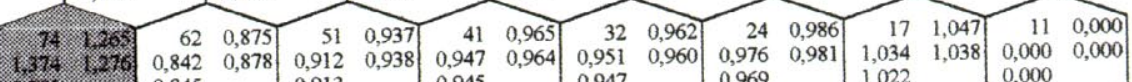

1.374: 1.276 0,842

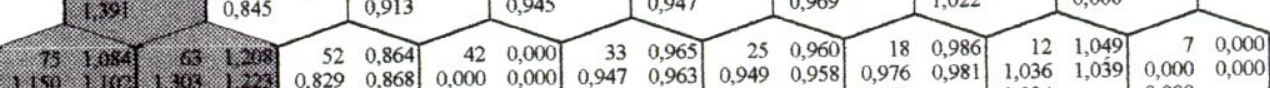

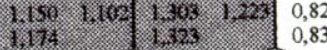
$0,945 \quad 0,945$

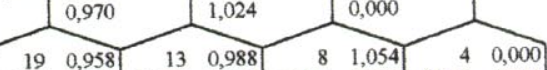

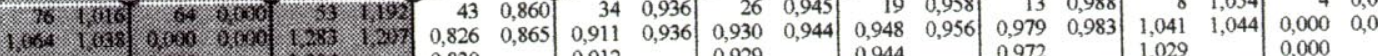

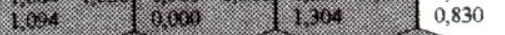

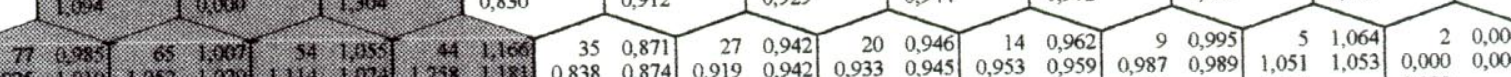

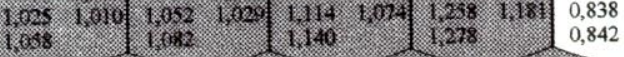

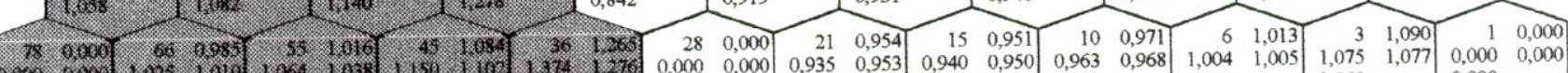

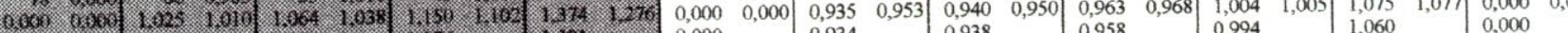


Figure 2.26. Simplified Design for "Increased Island-2" Type MOX LTA

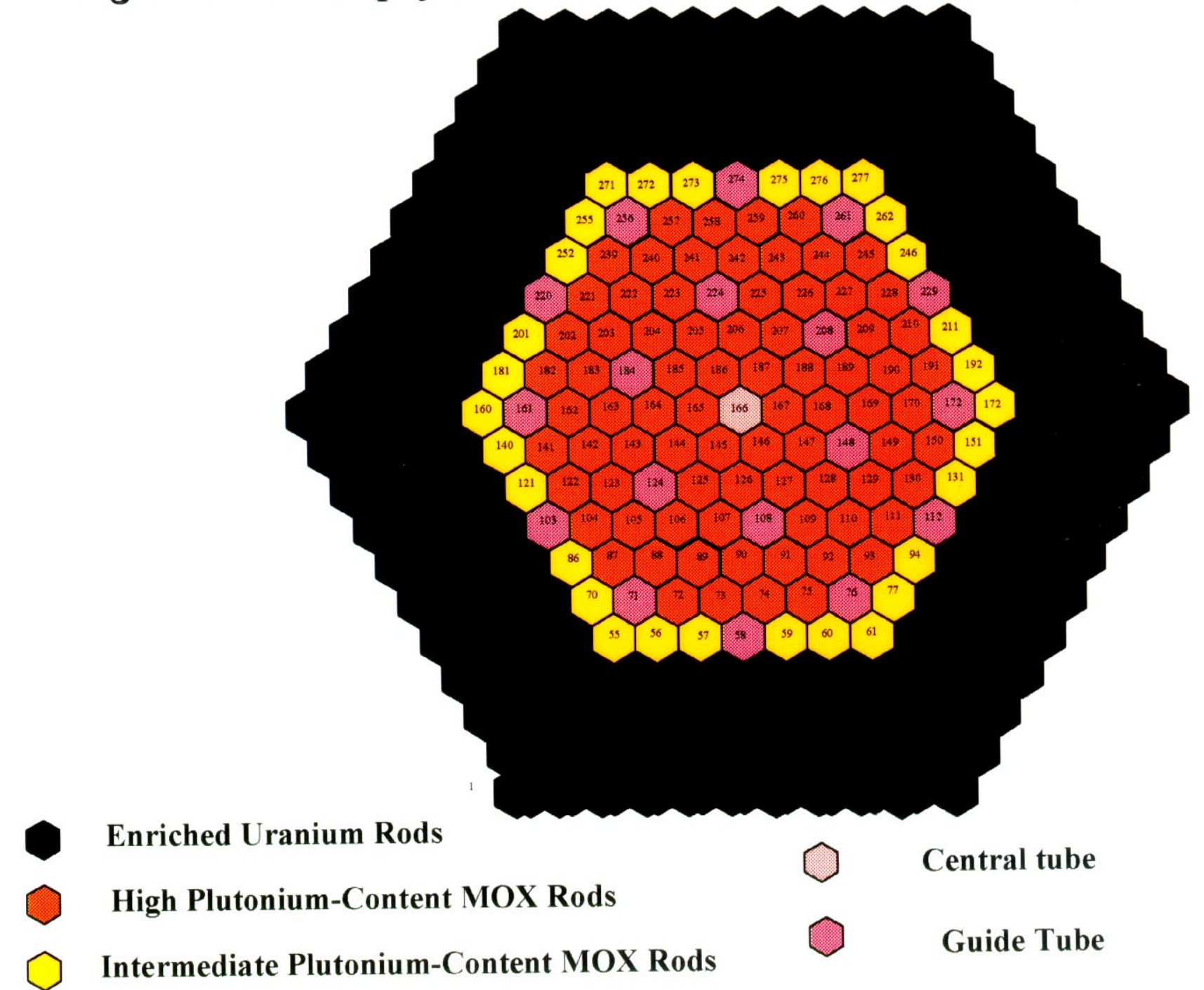

RRC KI. Design Studies of "Island" Type MOX Lead Test Assembly (Report for FY99) 
Fig. 2.27 Kk against "Island" periphery enrichment for different "Island" size. "Island central enrichment - 4.0\%.

Uranium enrichment $-3.7 \%$.

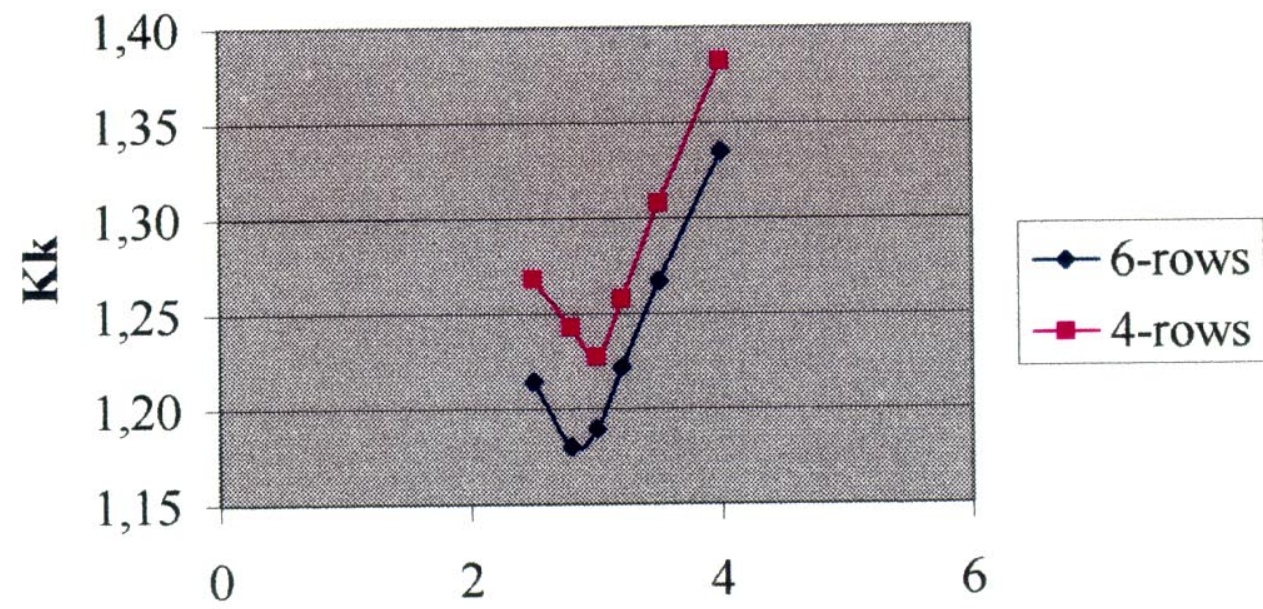

Plutonium enrichment in "Island" periphery (\%)

Fig. 2.28 Kk against "Island" periphery enrichment for different "Island" size. "Island central enrichment - 4.0\%. Uranium enrichment $-4.4 \%$.

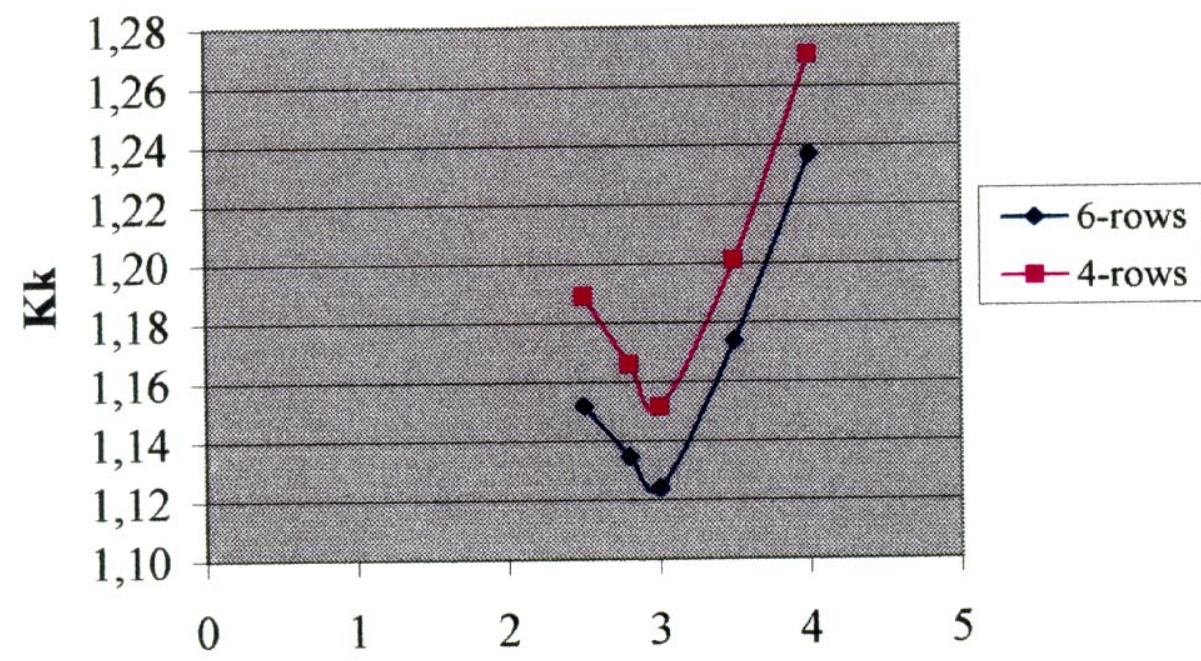

Plutonium enrichment in "Island" periphery (\%) 

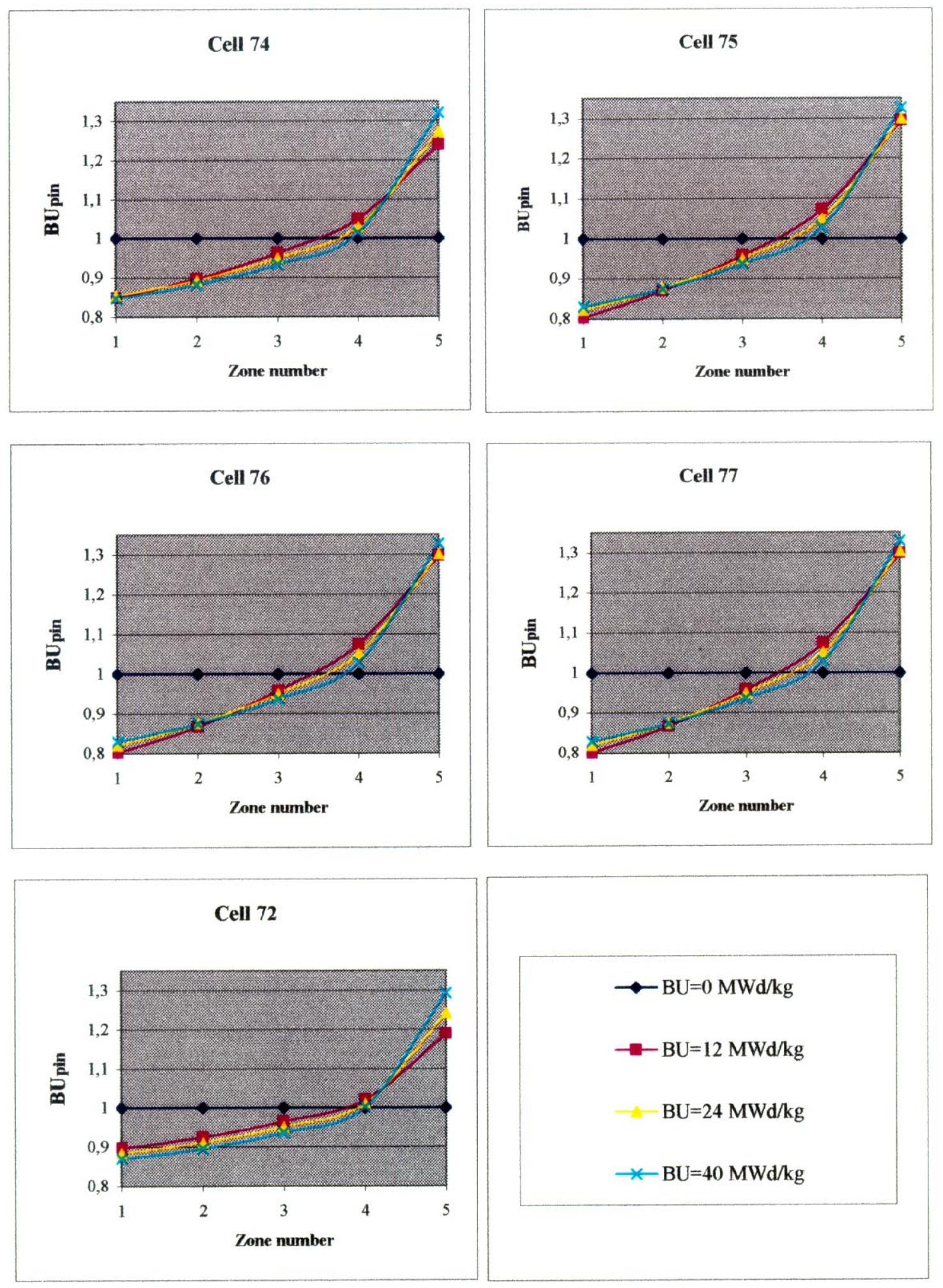

Fig. 2.29

Inter-pin relative burnup distribution 

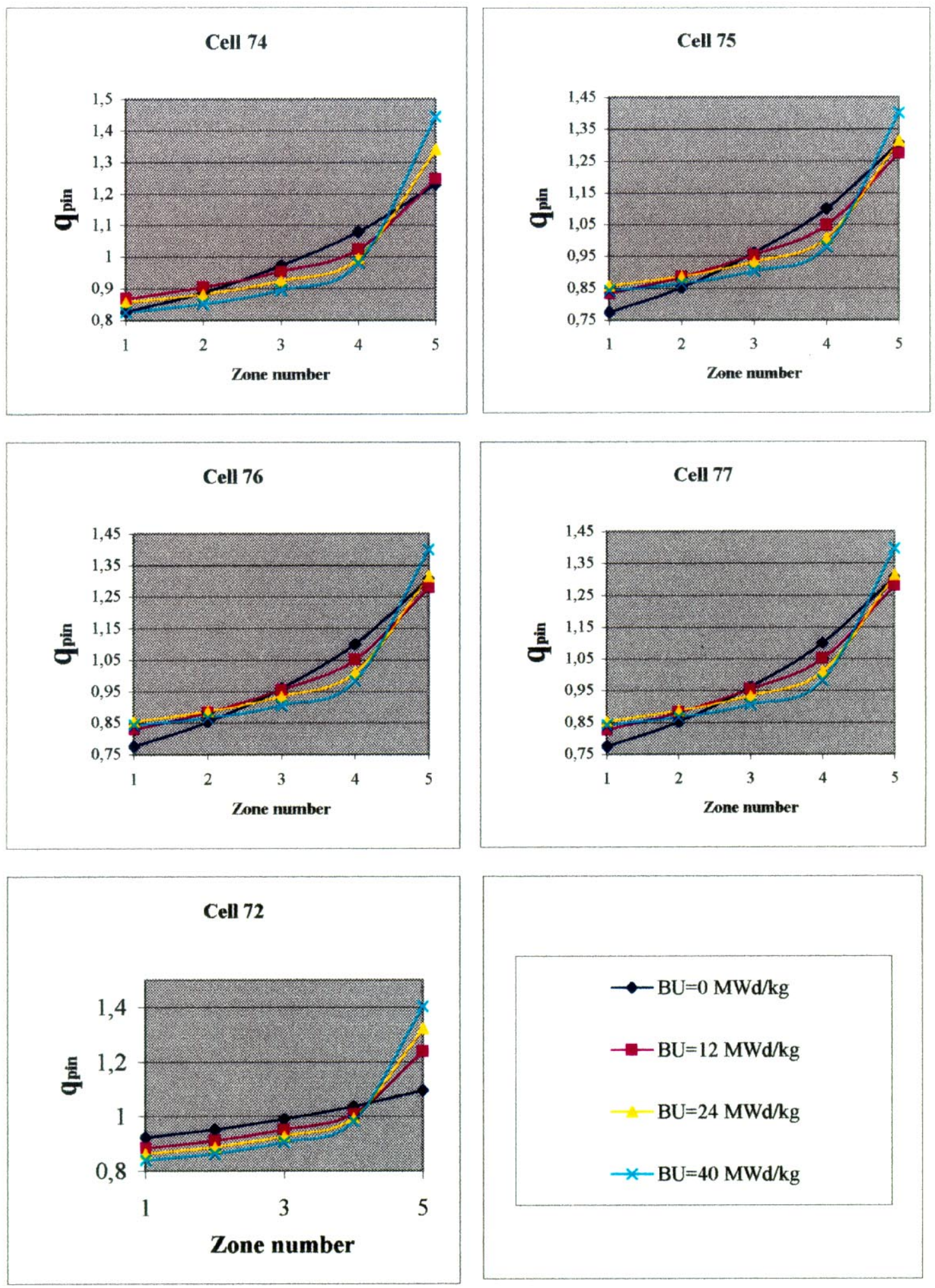

Fig. 2.30

Inter-pin relative power distribution 


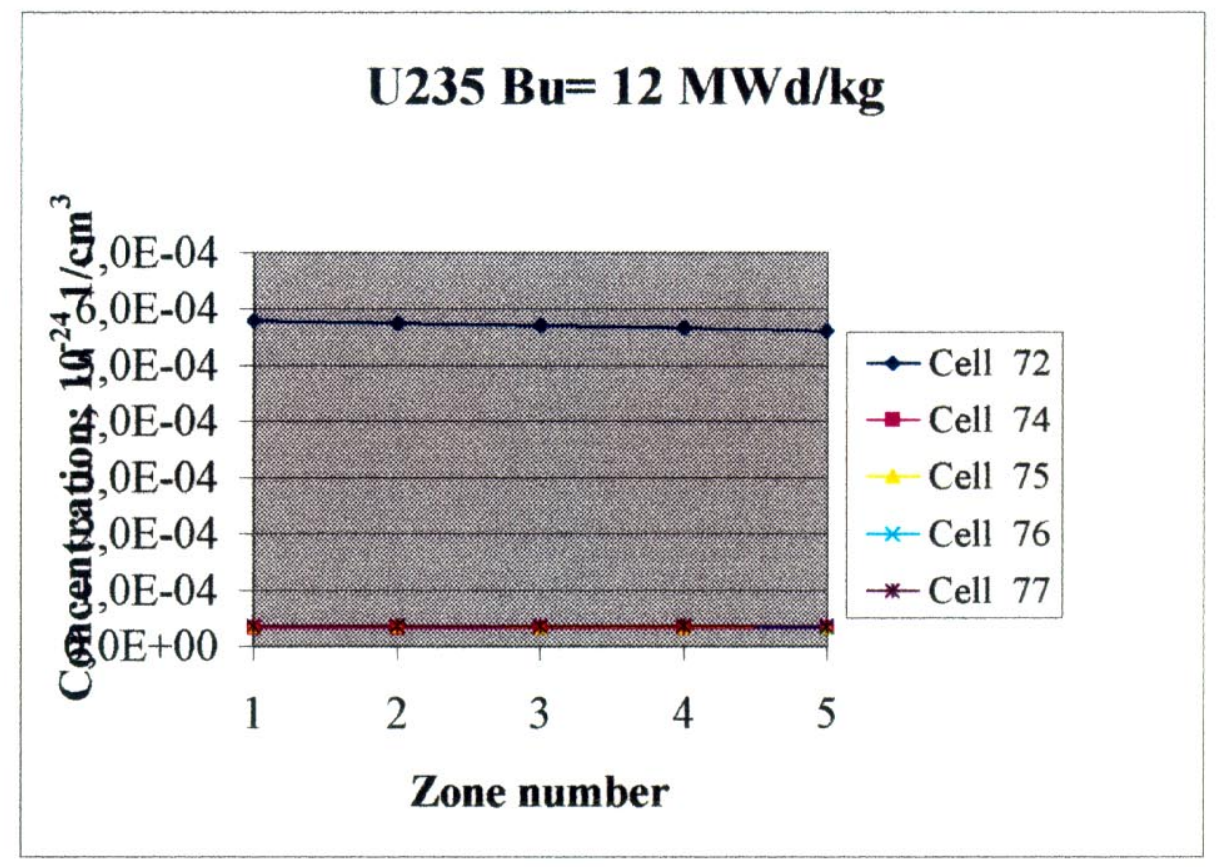

Fig. 2.31. Inter-pin isotopic distribution

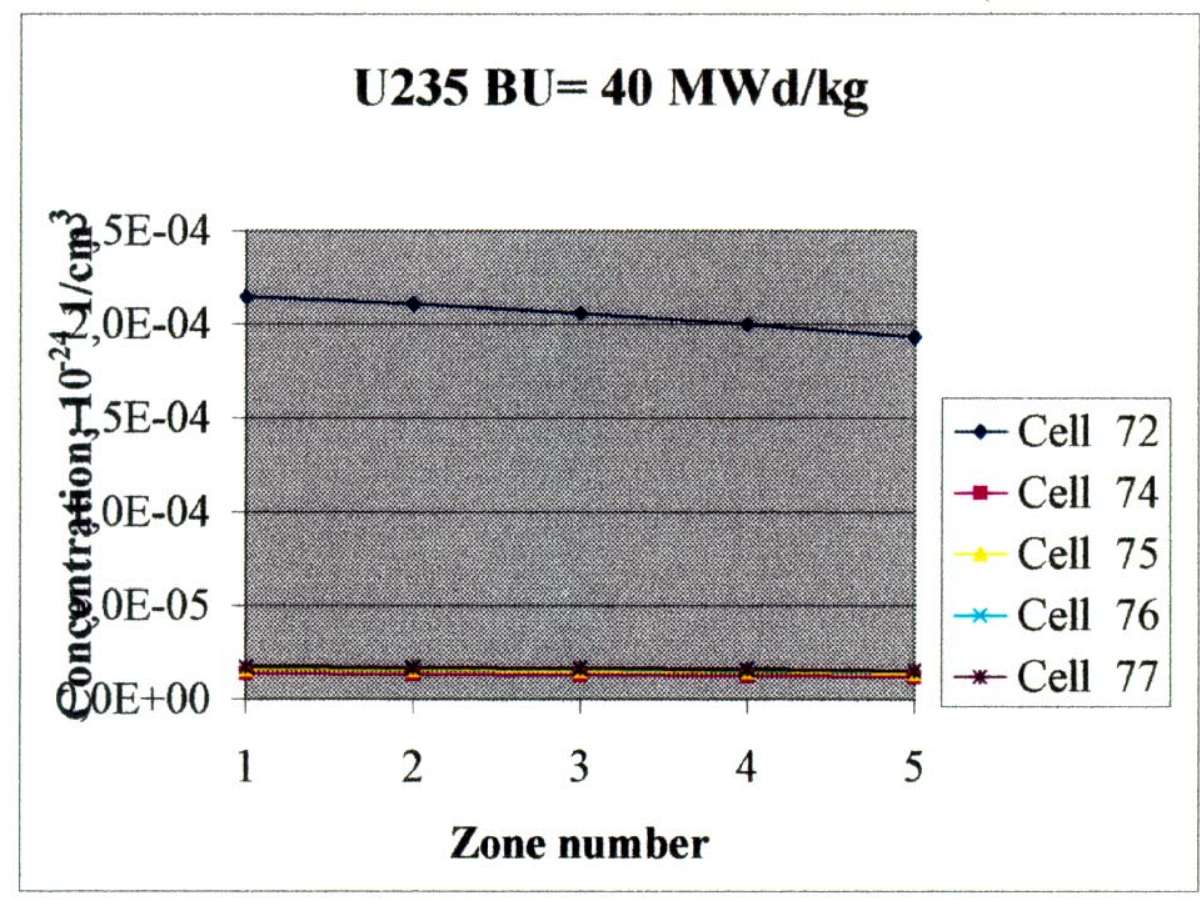

Fig. 2.32. Inter-pin isotopic distribution 


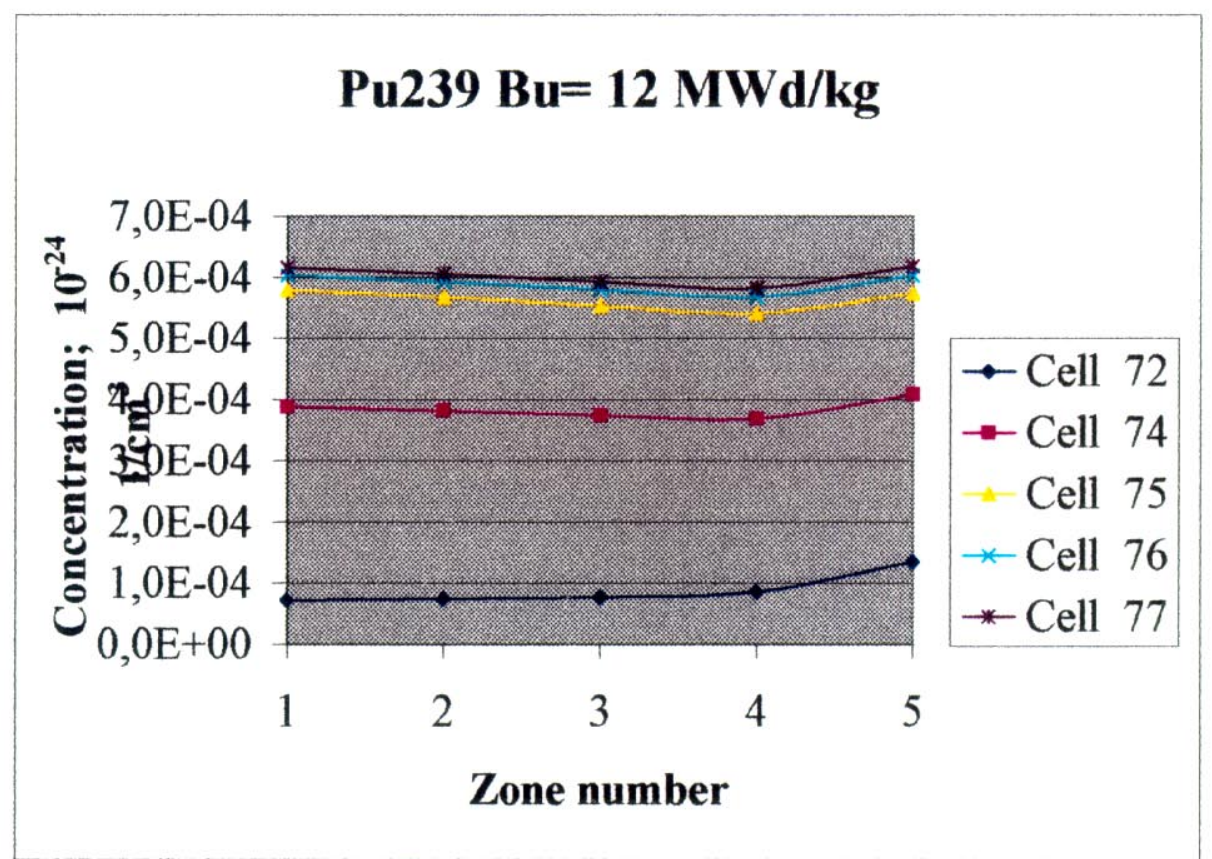

Fig. $2.33 \quad$ Inter-pin isotopic distribution

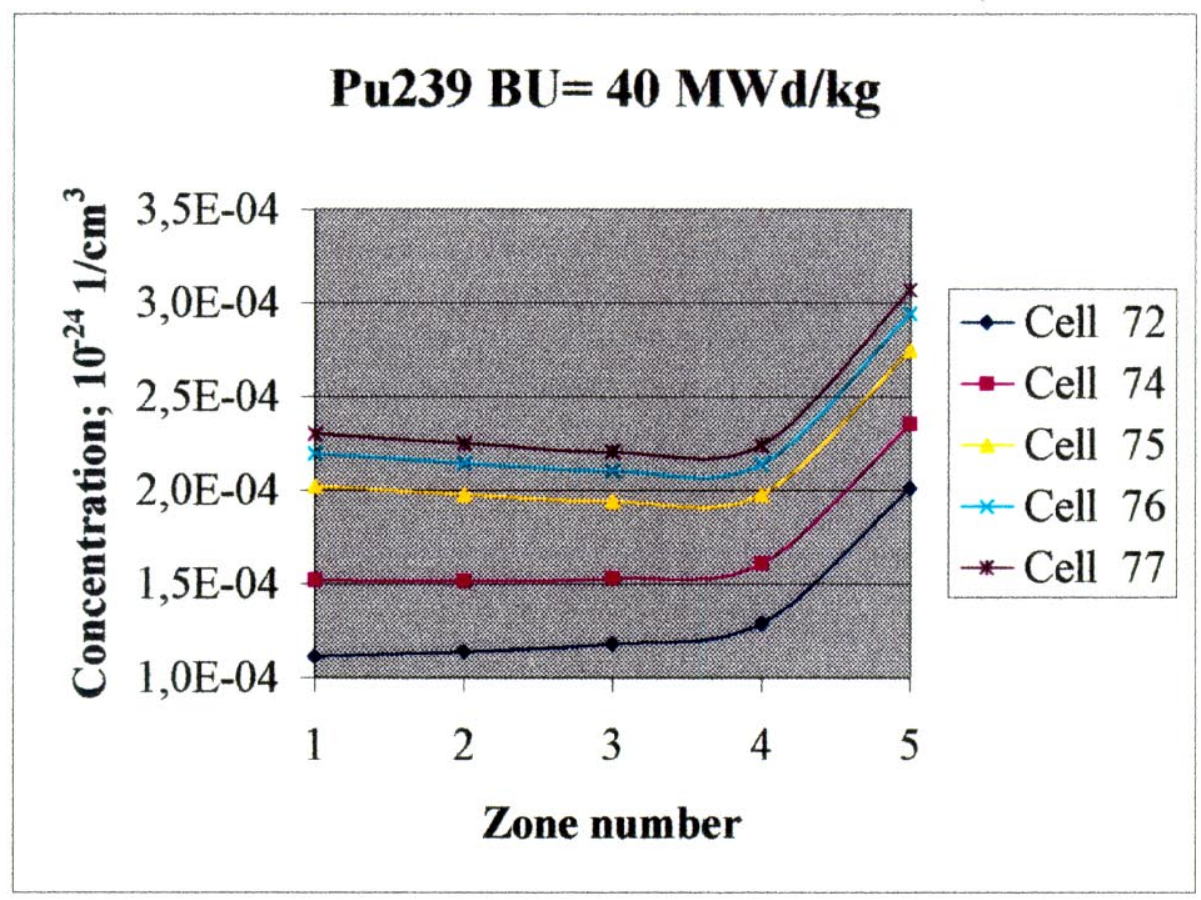

Fig. 2.34 Inter-pin isotopic distribution 


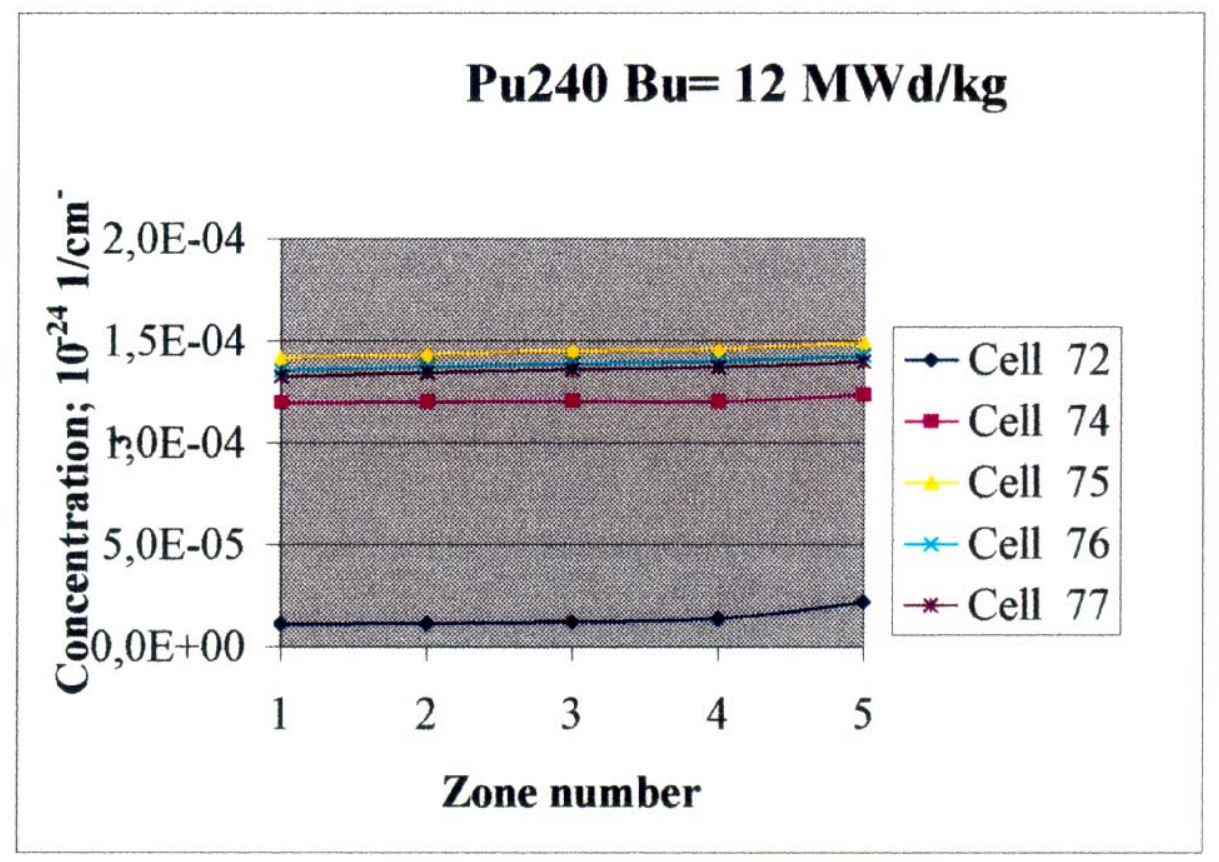

Fig. $2.35 \quad$ Inter-pin isotopic distribution

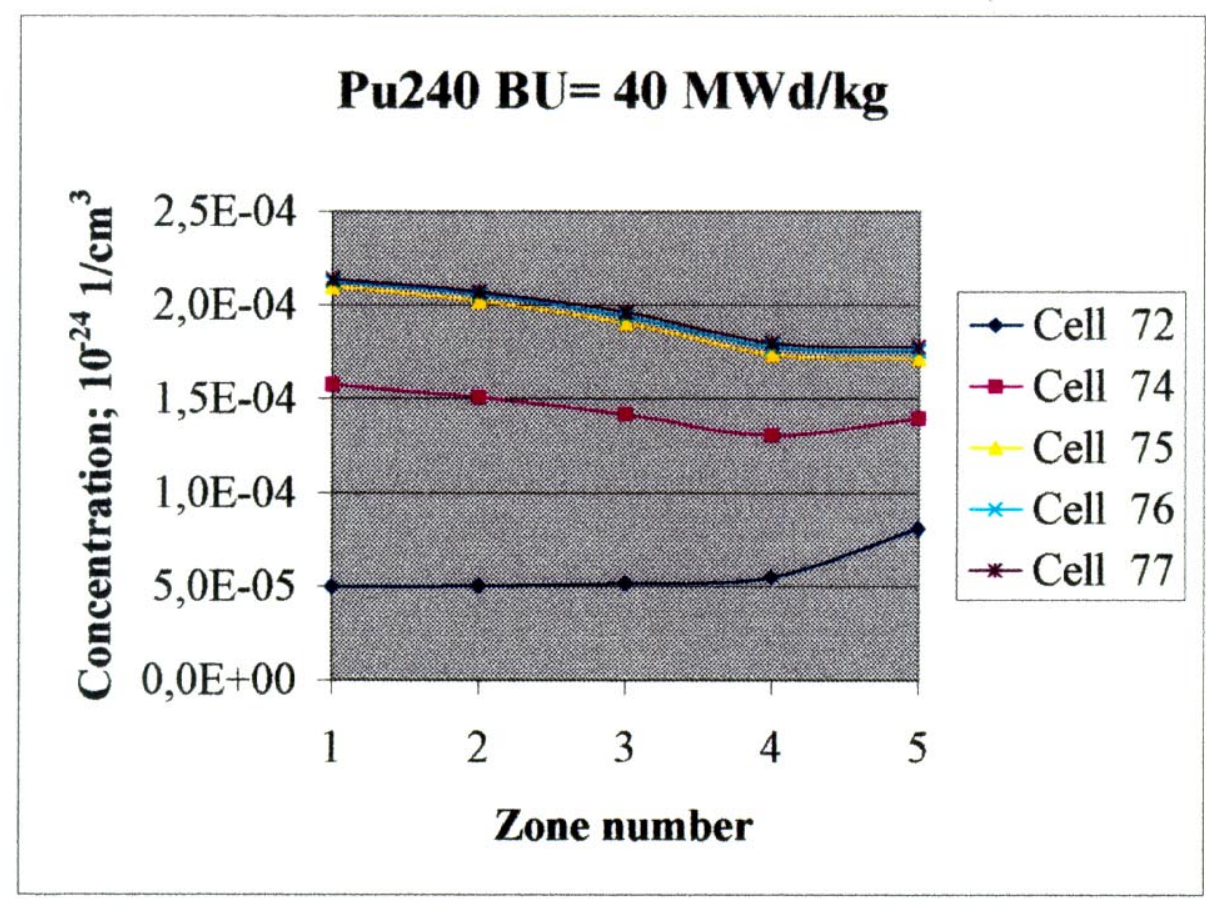

Fig. 2.36 Inter-pin isotopic distribution 


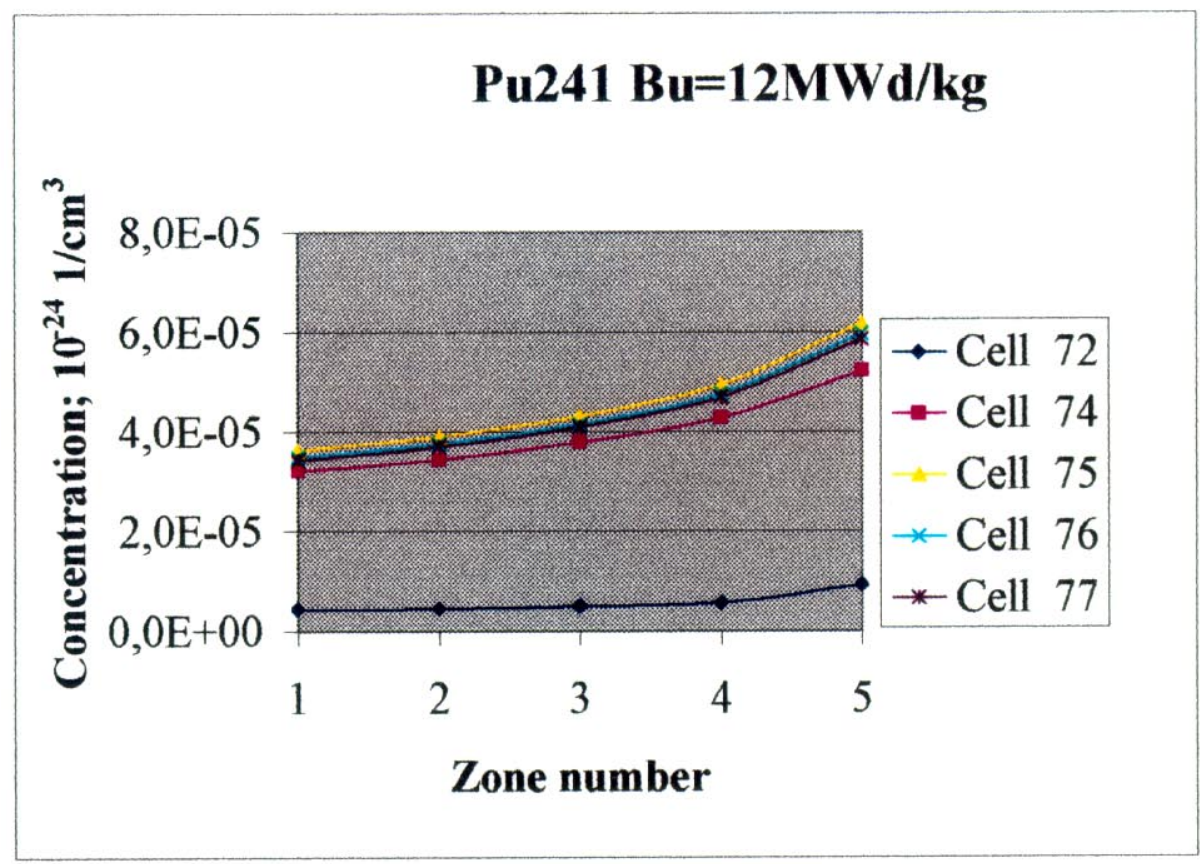

Fig. 2.37 Inter-pin isotopic distribution

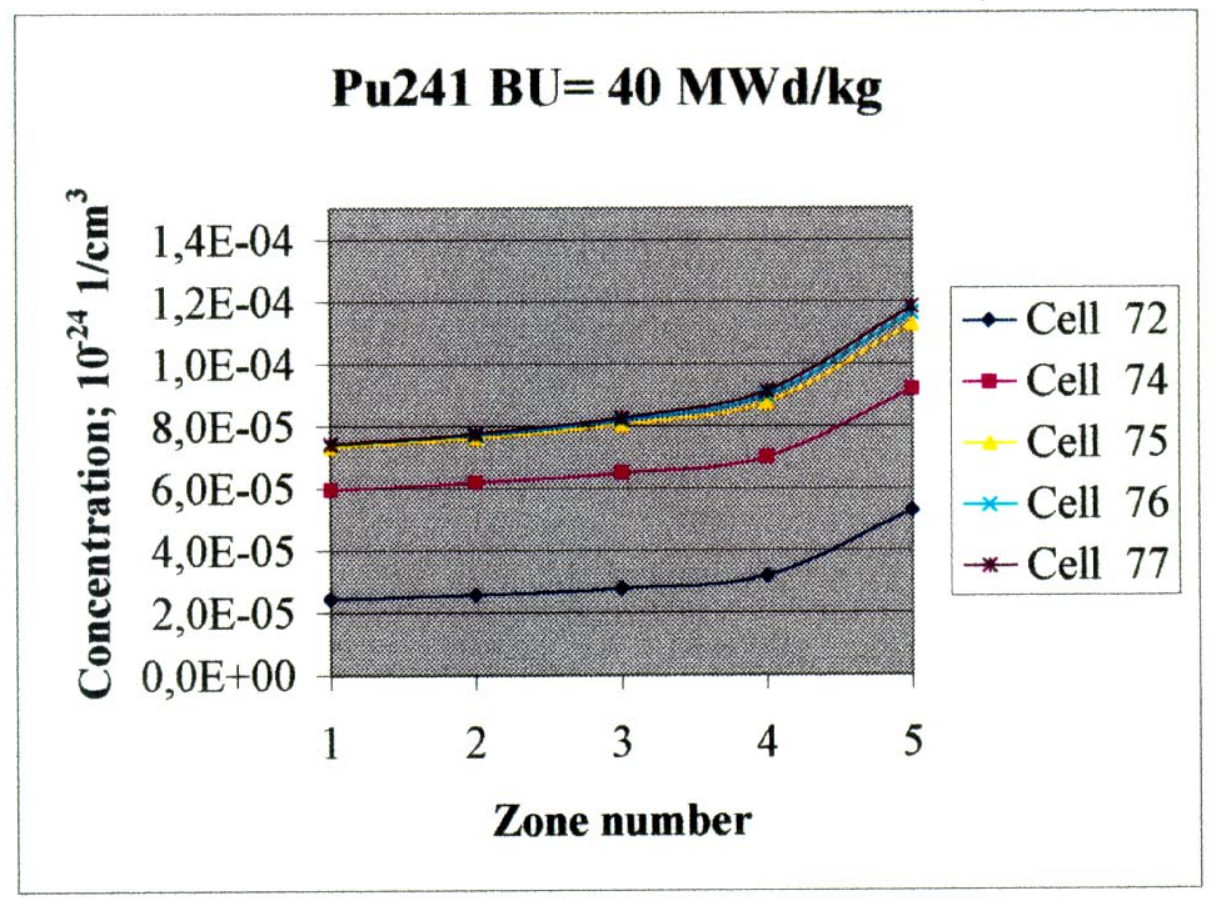

Fig. $2.38 \quad$ Inter-pin isotopic distribution 


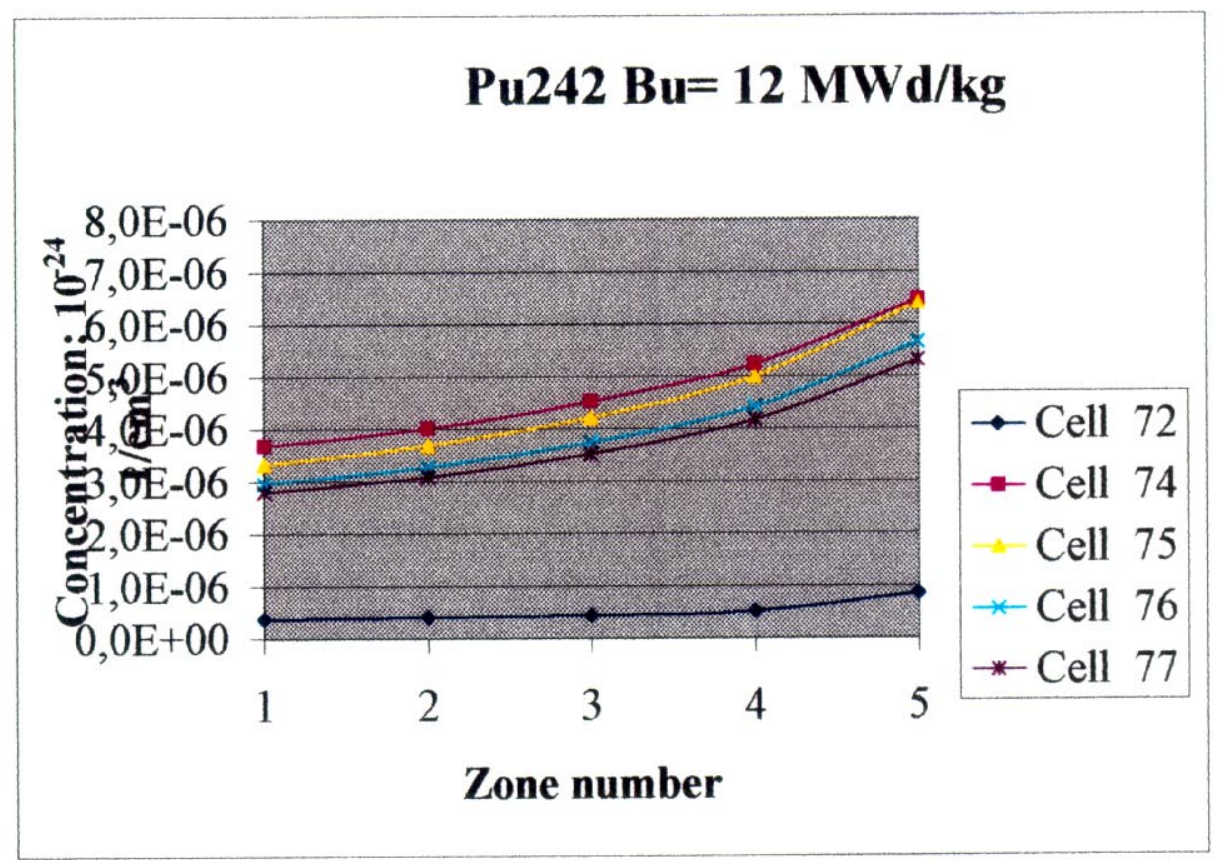

Fig. 2.39 Inter-pin isotopic distribution

\section{Pu242 BU $=40 \mathrm{MWd} / \mathrm{kg}$}

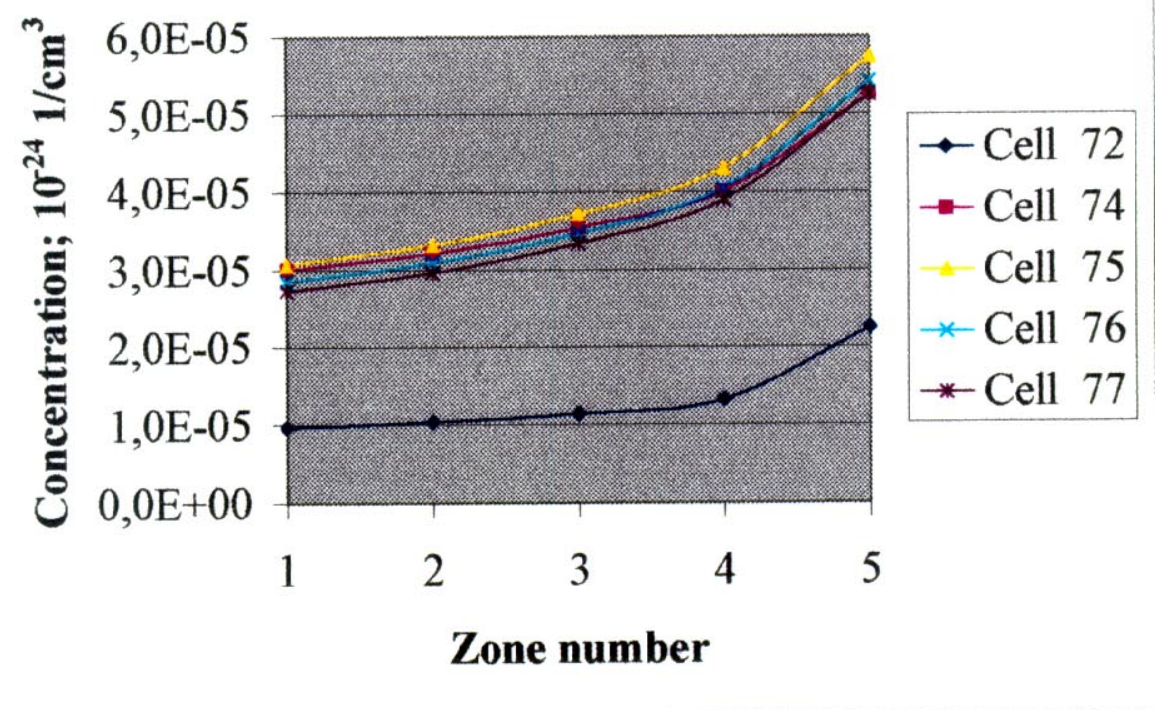

Fig. $2.40 \quad$ Inter-pin isotopic distribution 
RRC KI. Design Studies of "Island" Type MOX Lead Test Assembly (Report for FY99)

H:SERV__AMIDATAQWU38_pu38_so
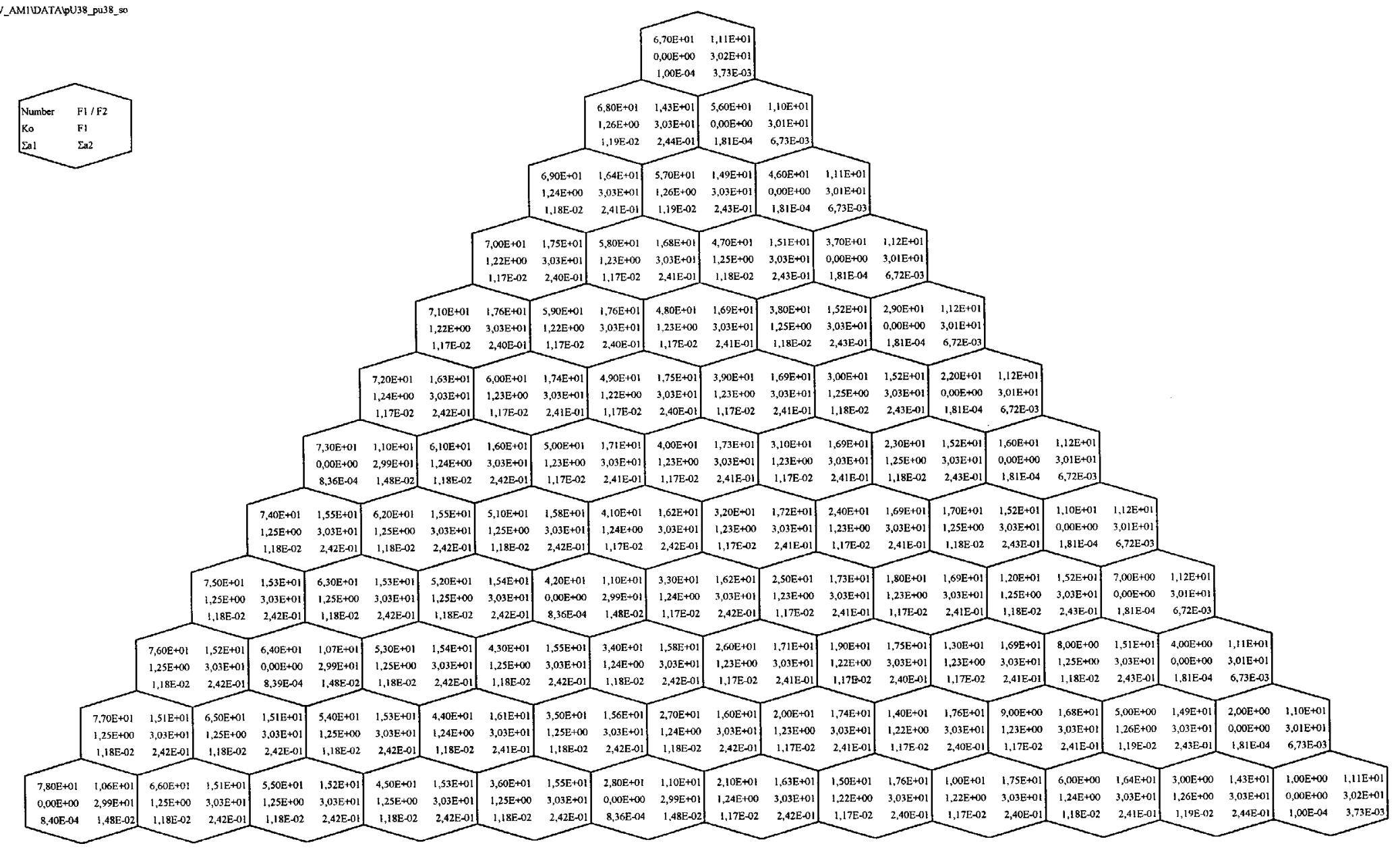

Fig. 2.41 Spectrum parameters distribution in MOX assembly ( $\mathrm{Pu} 3.8$. Sector $60^{\circ}$ ) 

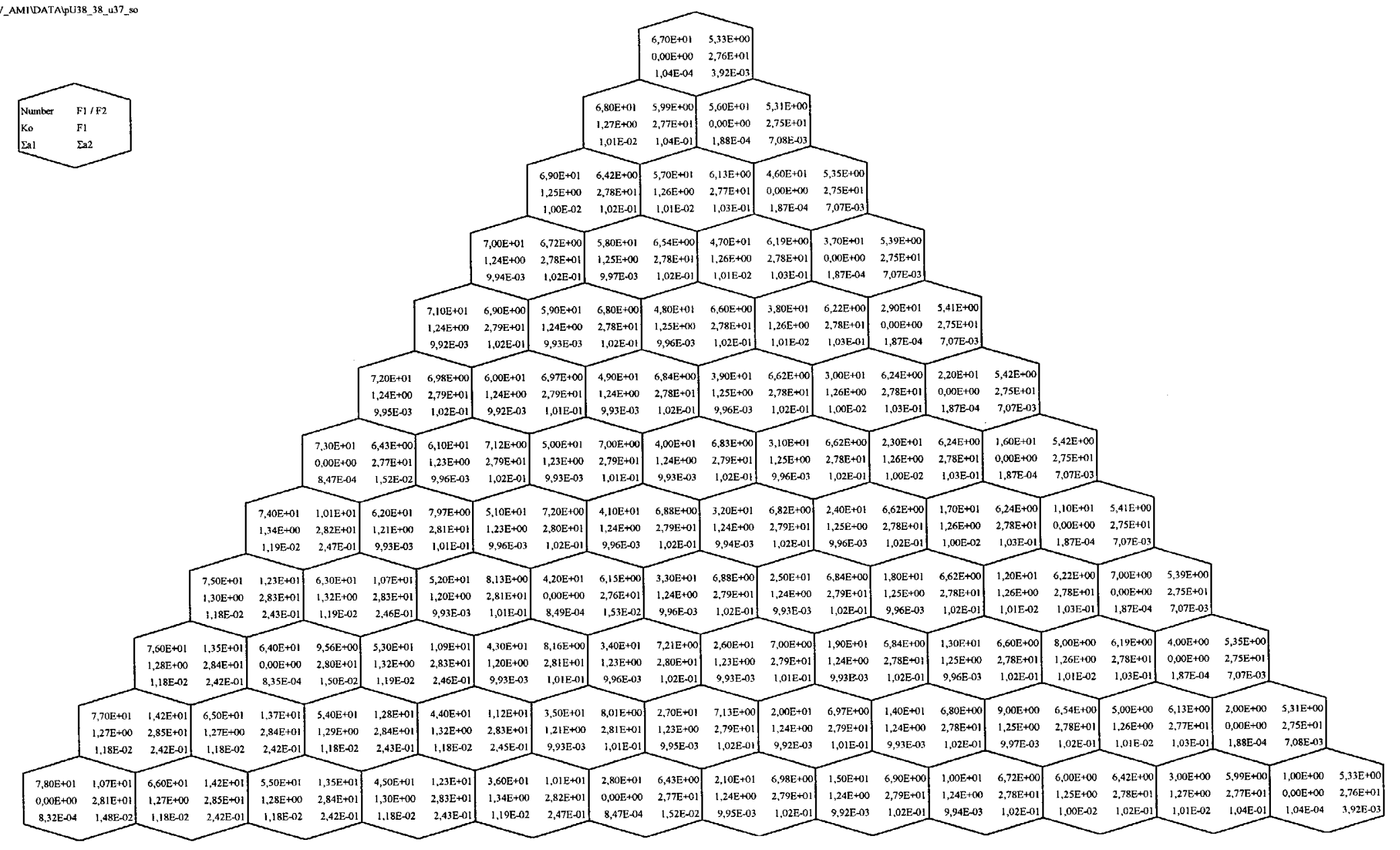

Fig. 2.42 Spectrum parameters distribution in "Island" type MOX assembly ( Pu 3.8_3.8_U 3.7. Sector 60 $)$ 


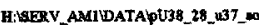
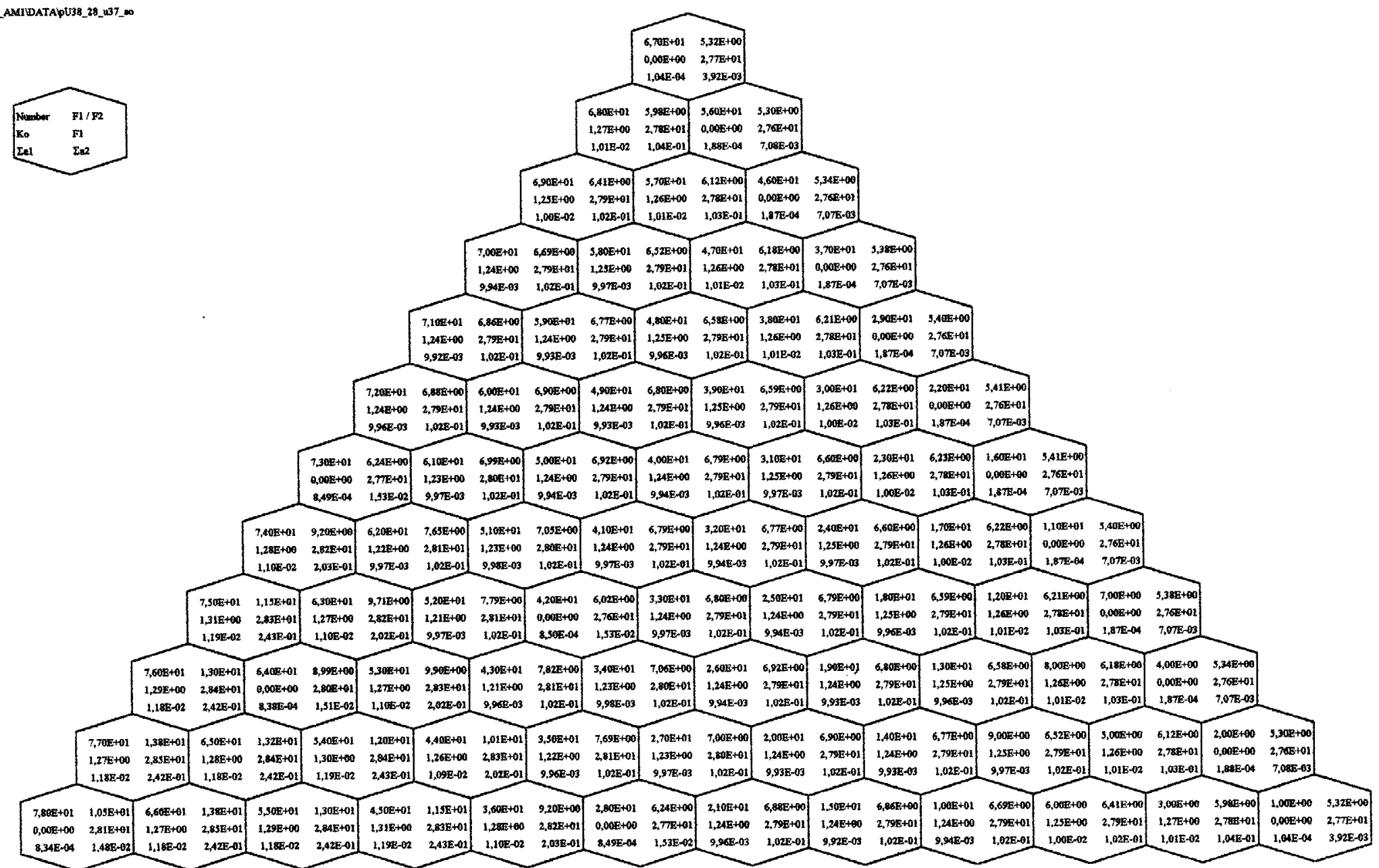

Fig. 2.43 Spectrum parameters distribution in "Island" type MOX assembly (Pu 3.8_2.8_U 3.7. Sector 60o) 
RRC KI. Design Studies of "Island" Type MOX Lead Test Assembly (Report for FY99)

pu38 $28 \quad$ u37o

Current Burnup $0 \mathrm{MWtd} / \mathrm{kg}$

Power Distribution

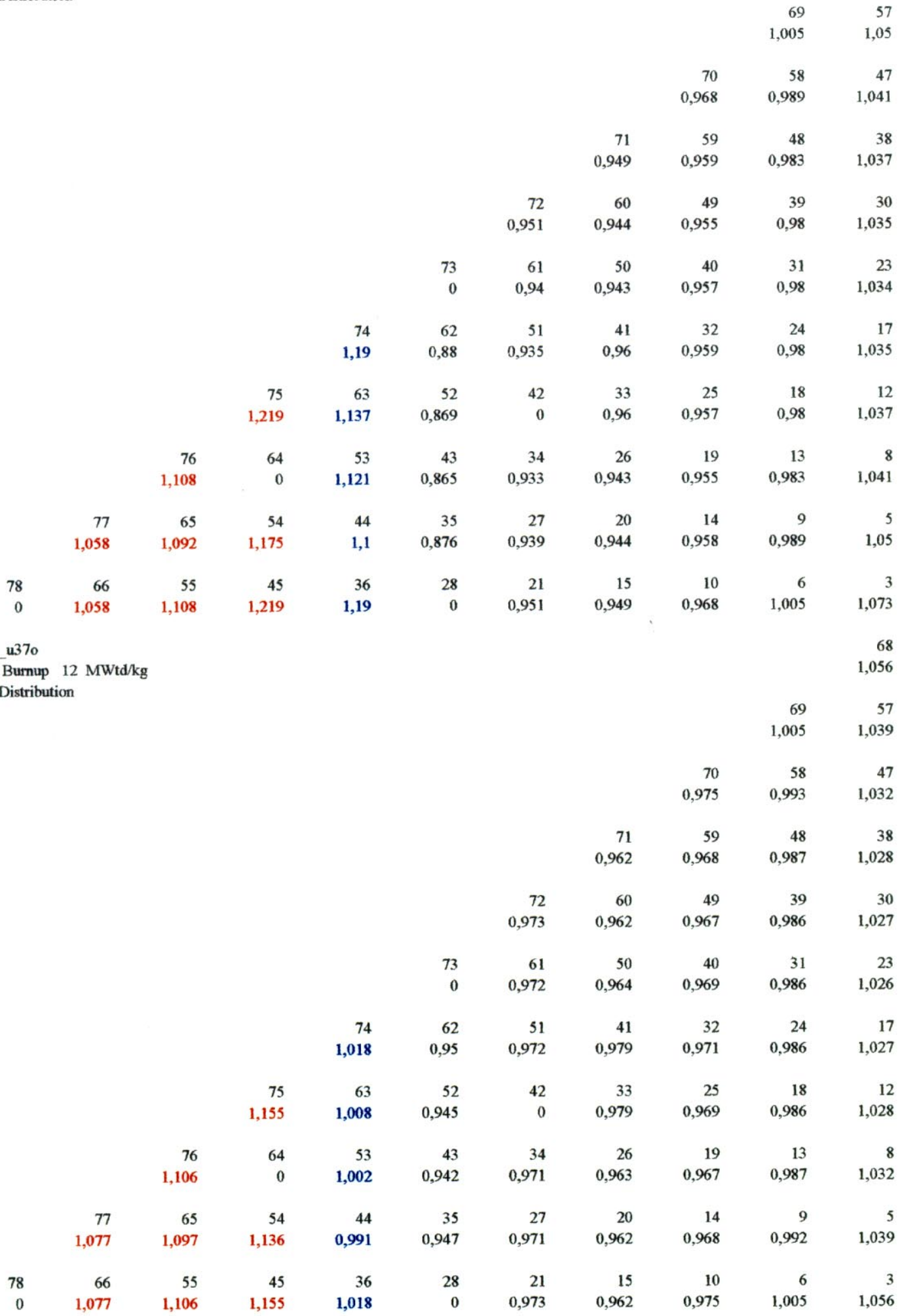

Fig. 2.44 Power distribution evolution in "Island" type MOX assembly (Pu3.8_2.8_U3.7 Sector 60 $0^{\circ}$ ) 


\section{RRC KI. Design Studies of “Island” Type MOX Lead Test Assembly (Report for FY99)}

pu38 28 u37o

Current Burnup $24 \mathrm{MWtd} / \mathrm{kg}$

Power Distribution

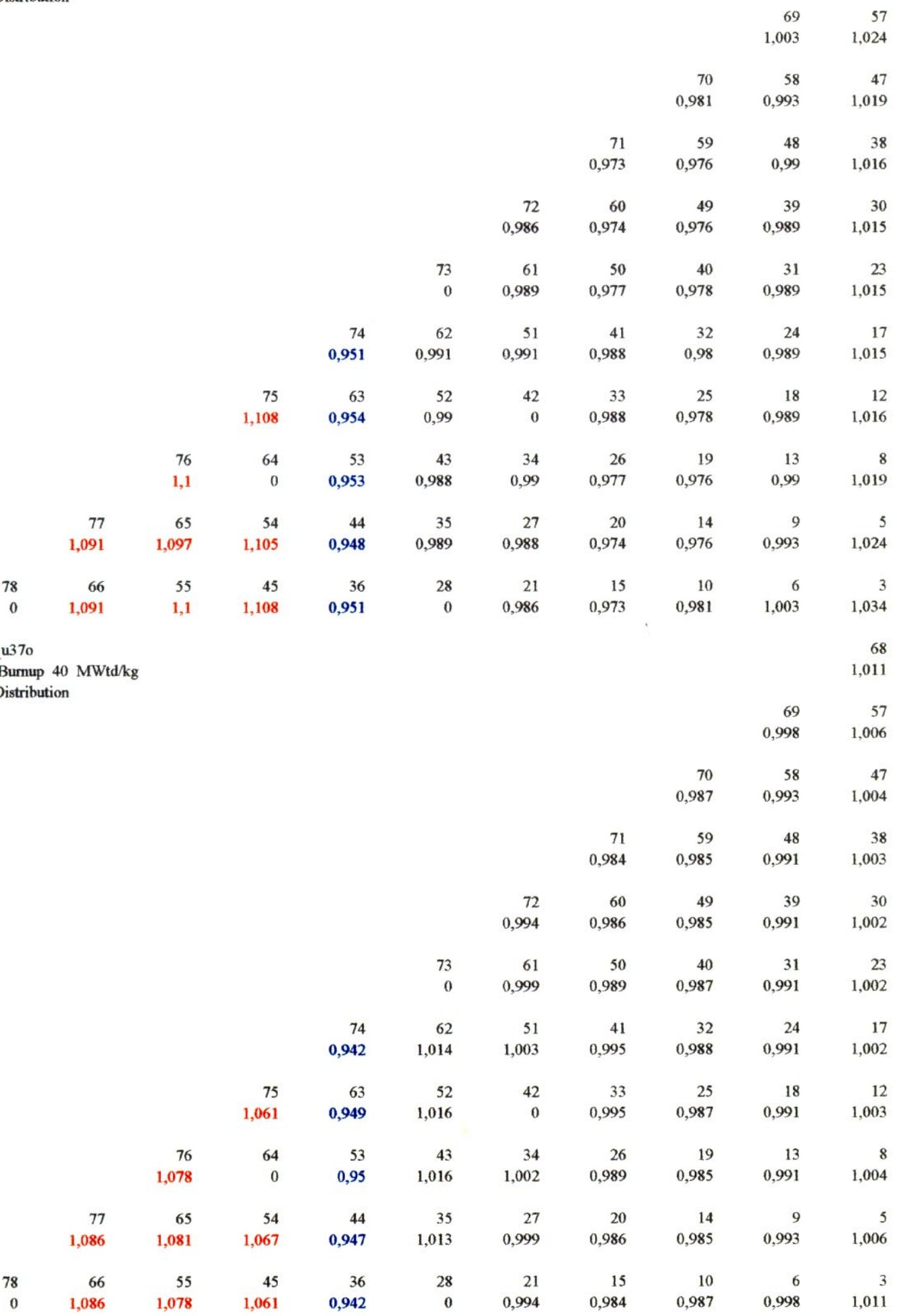

Fig. 2.45 Power distribution evolution in "Island" type MOX assembly (Pu3.8_2.8_U3.7 Sector 60 $0^{\circ}$ ) 


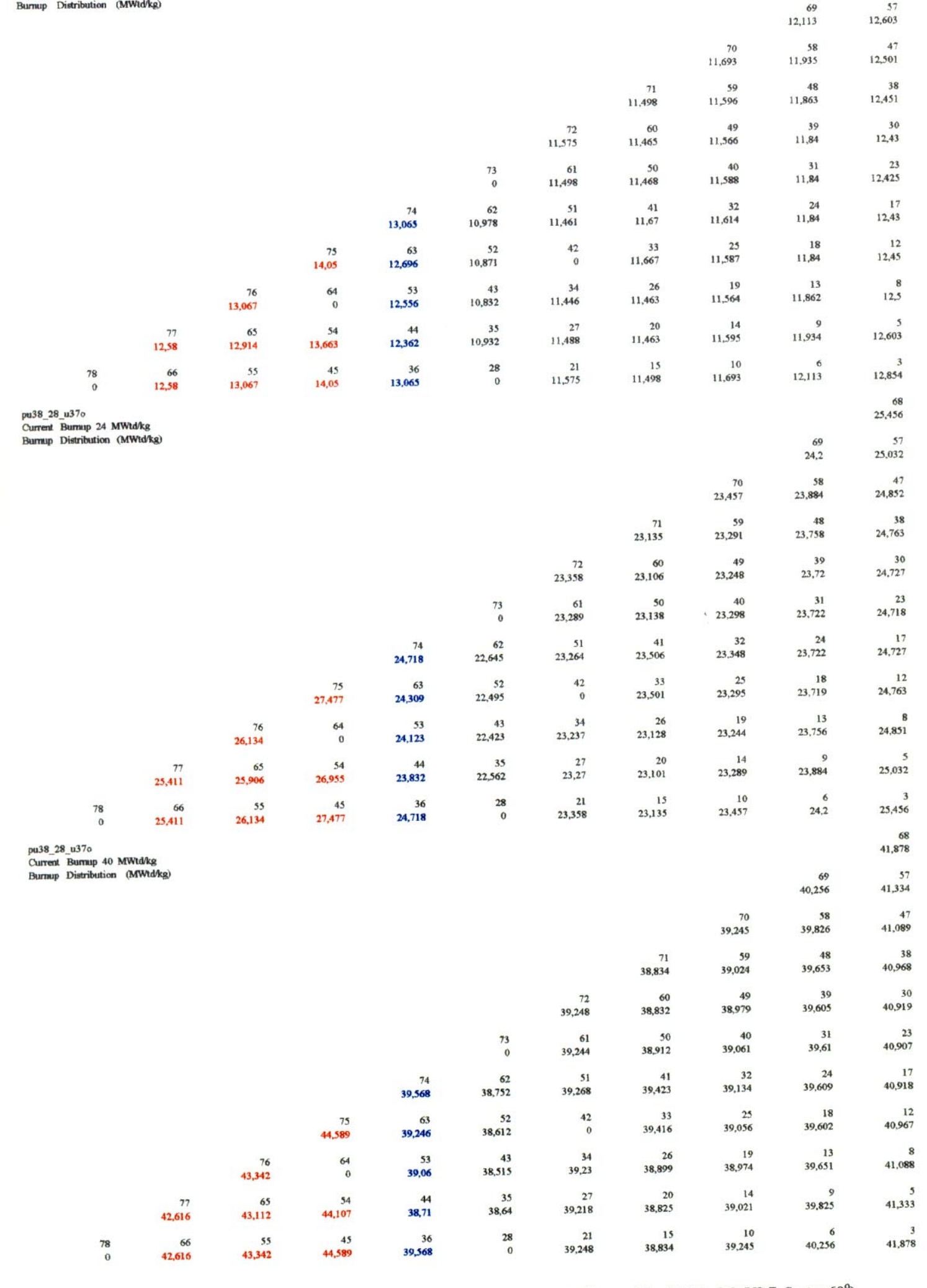


RRC KI. Design Studies of "Island" Type MOX Lead Test Assembly (Report for FY99)
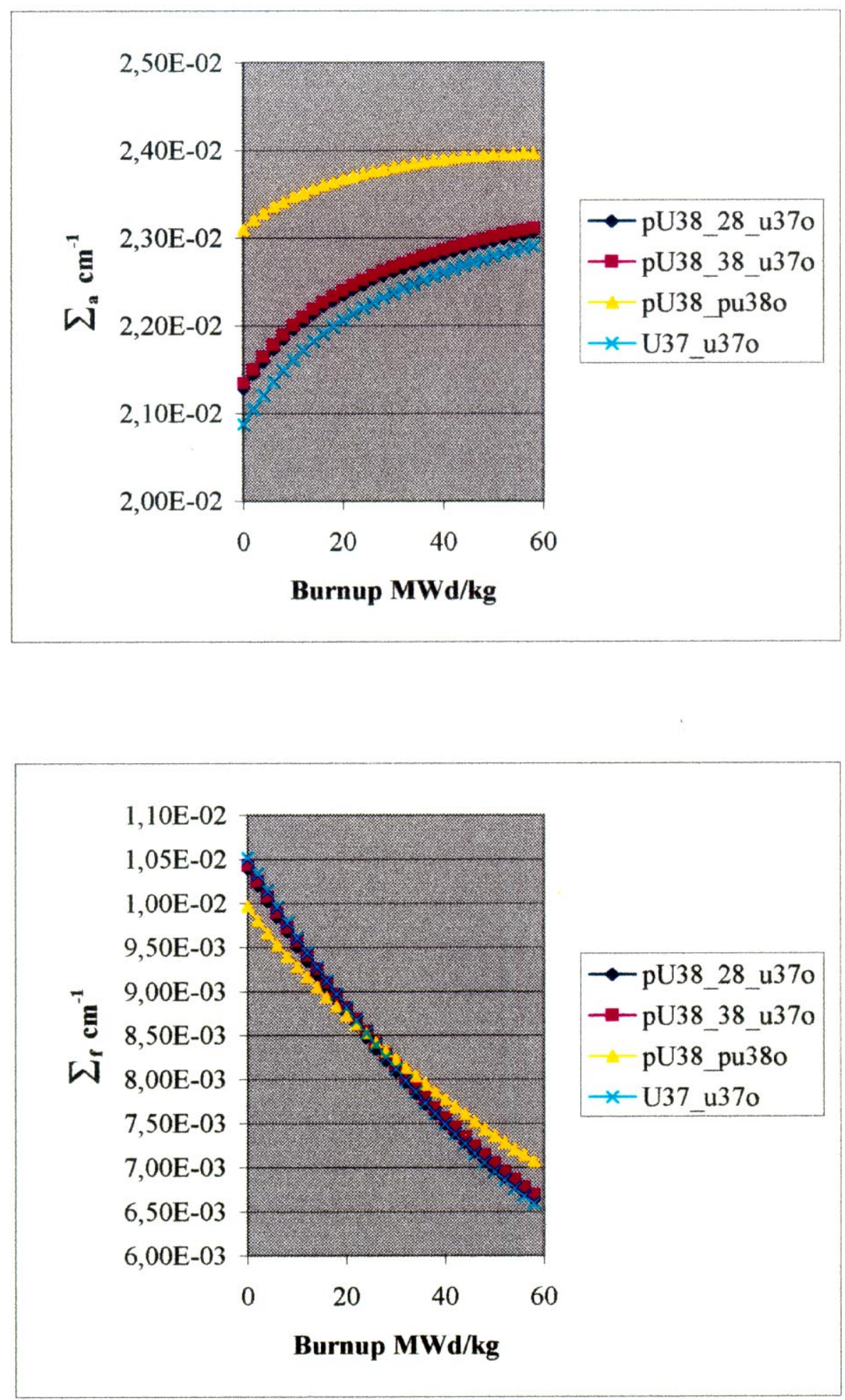

Fig. 2.47 Assembly parameters evolution for different enrichment compositions 
RRC KI. Design Studies of "Island” Type MOX Lead Test Assembly (Report for FY99)
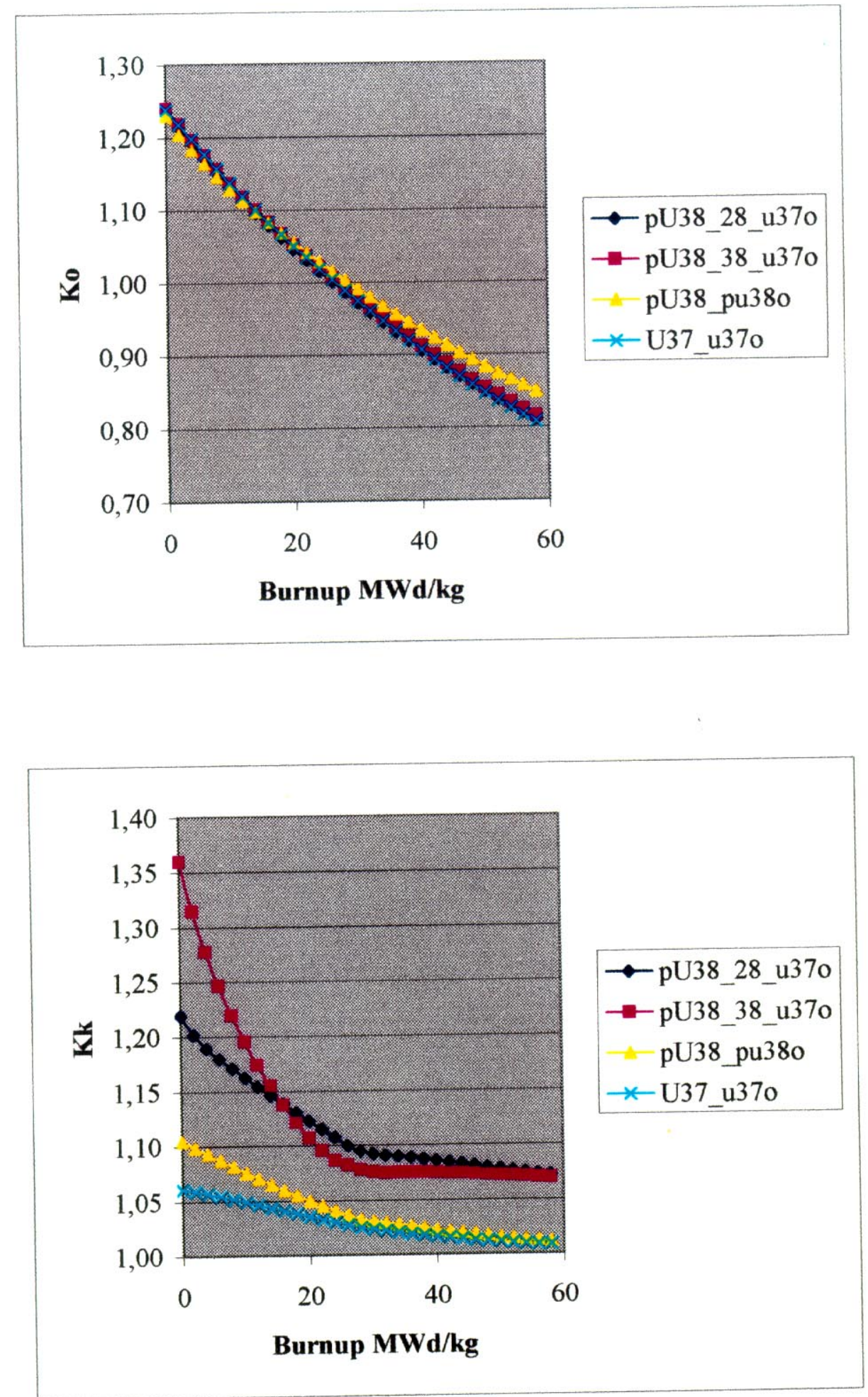

Fig. 2.48 Assembly parameters evolution for different enrichment compositions 
RRC KI. Design Studies of "Island" Type MOX Lead Test Assembly (Report for FY99)

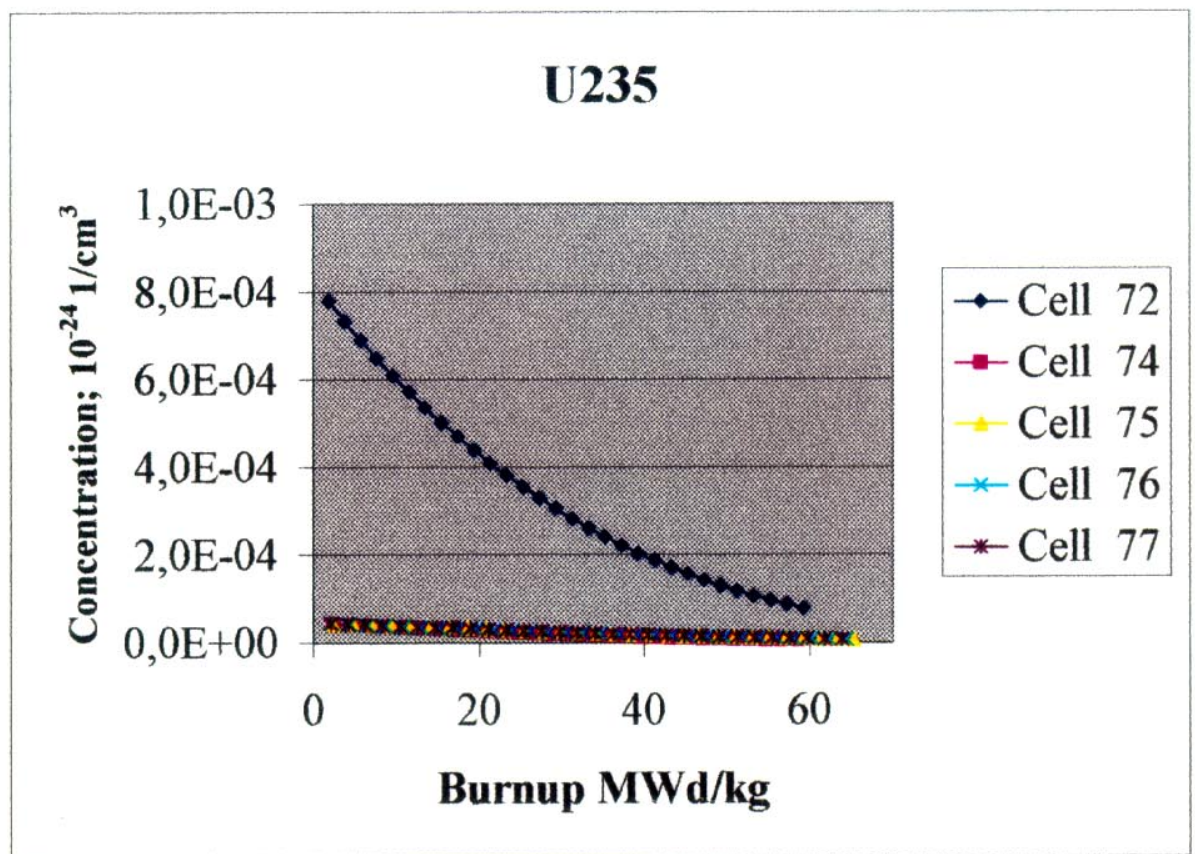

Fig. 2.49

Evolution of pin isotopic content

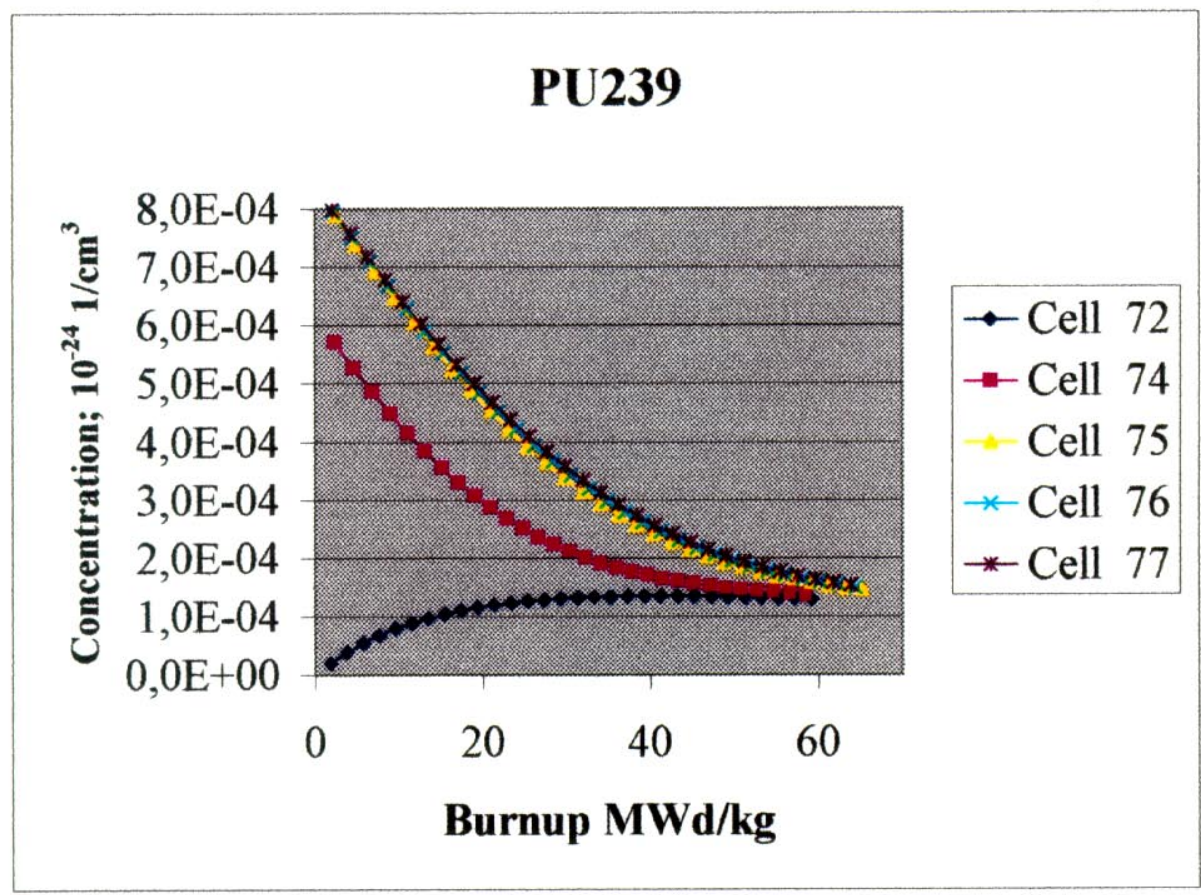

Fig. $2.50 \quad$ Evolution of pin isotopic content 
RRC KI. Design Studies of "Island" Type MOX Lead Test Assembly (Report for FY99)

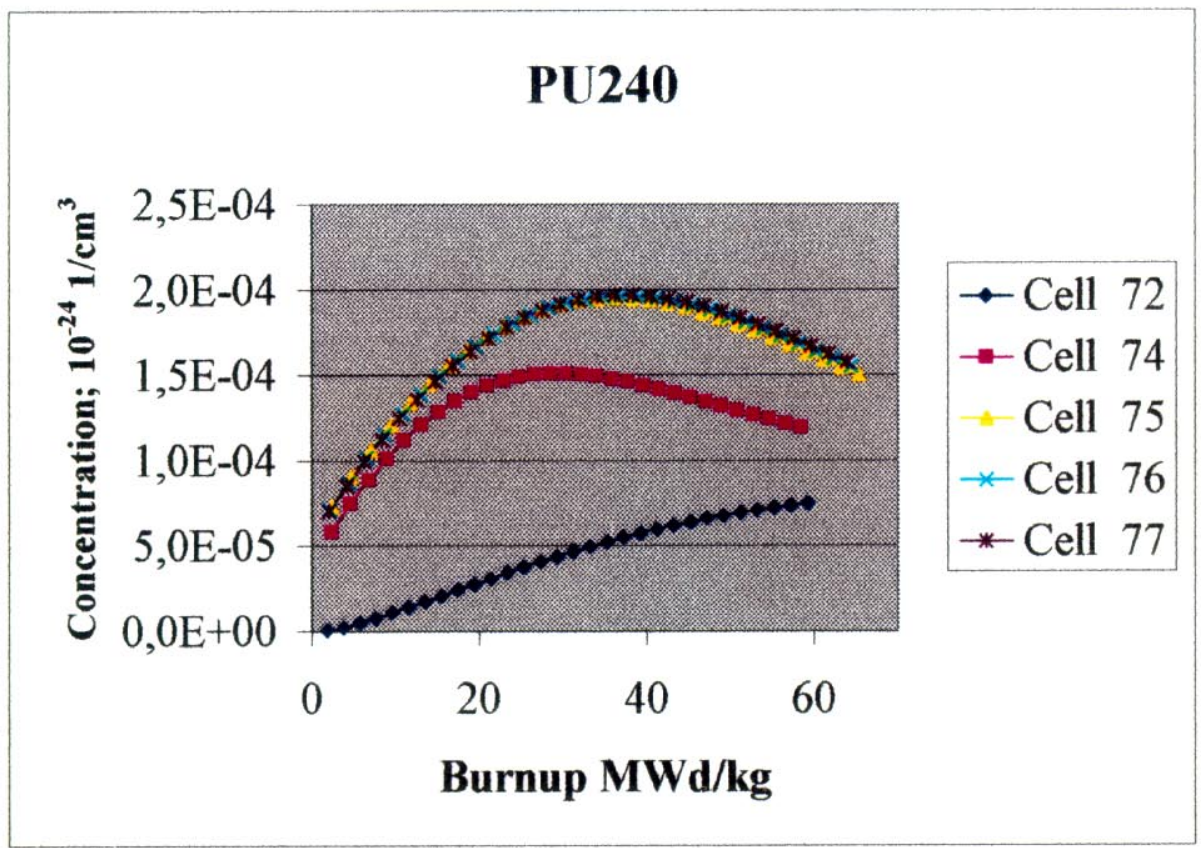

Fig. 2.51 Evolution of pin isotopic content

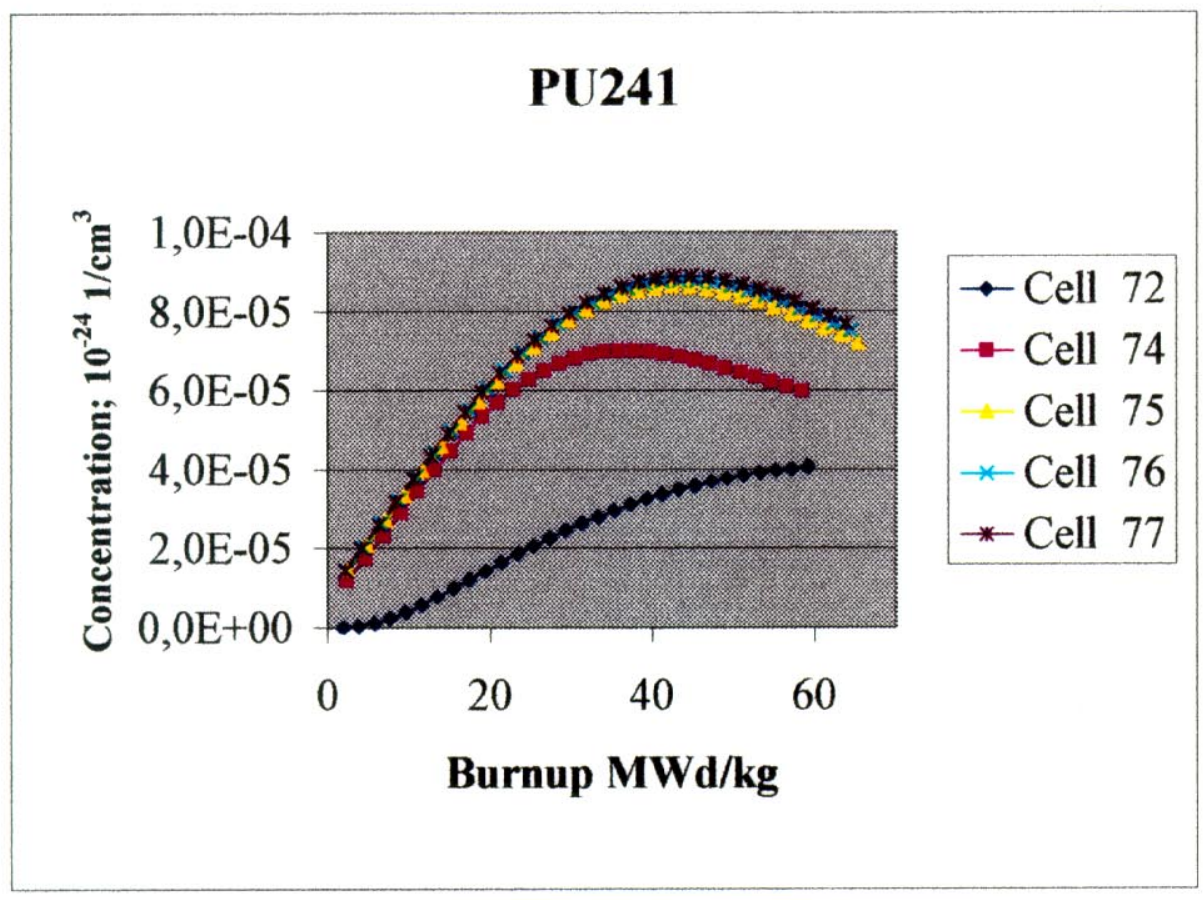

Fig. $2.52 \quad$ Evolution of pin isotopic content 
RRC KI. Design Studies of "Island" Type MOX Lead Test Assembly (Report for FY99)

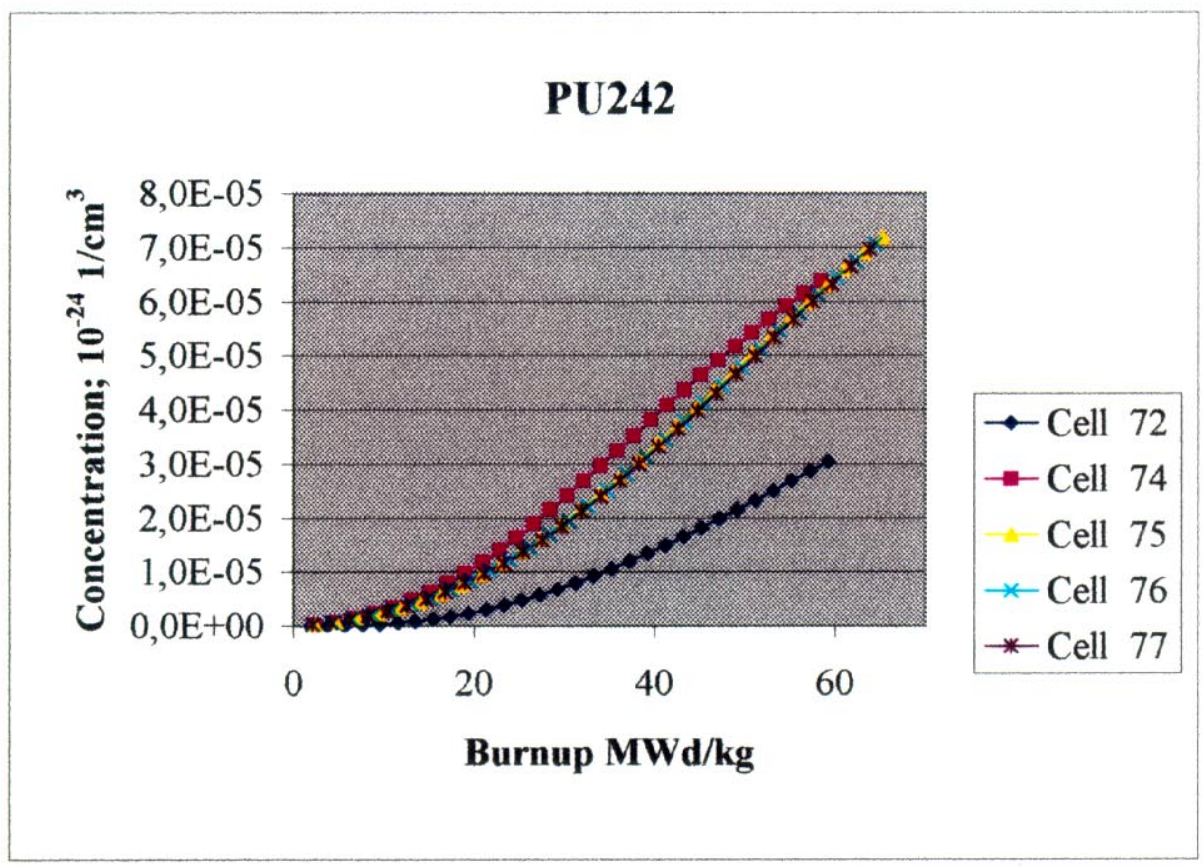

Fig. 2.53 Evolution of pin isotopic content

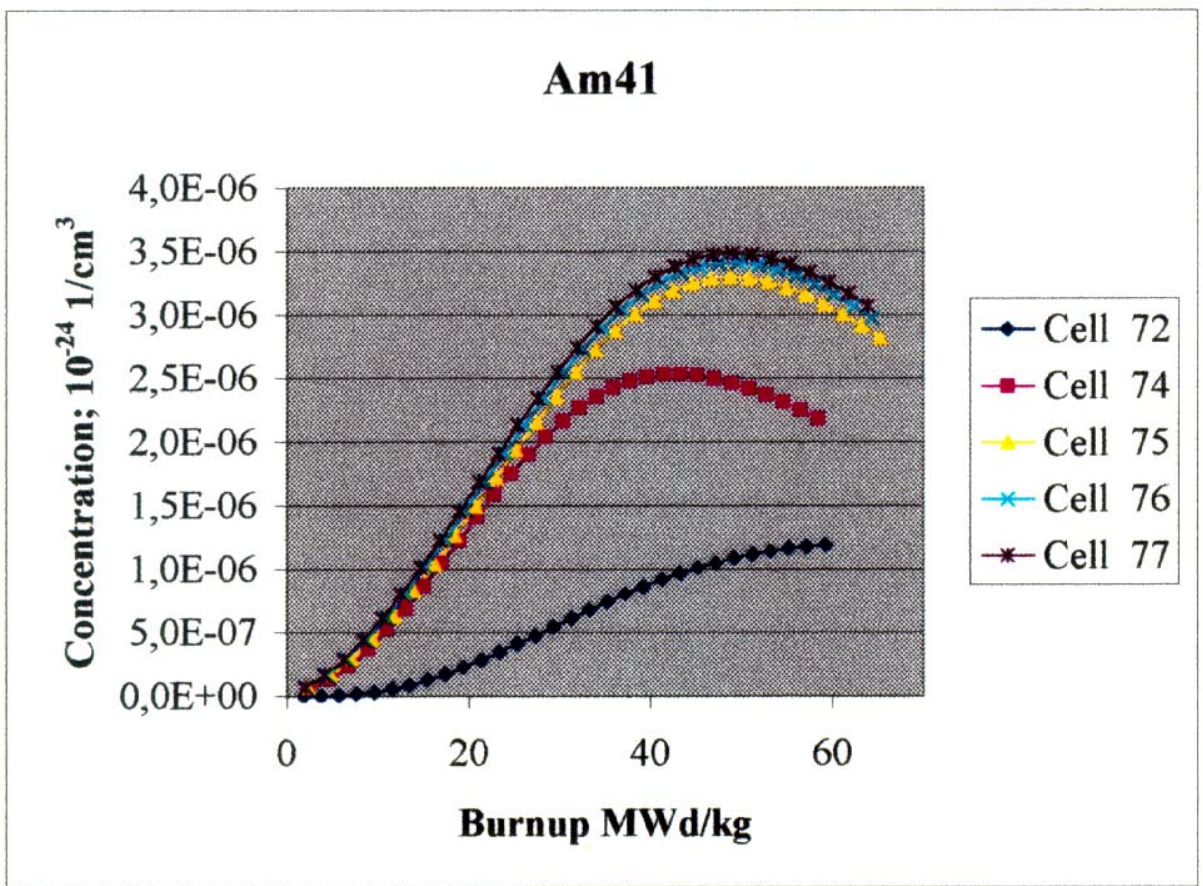

Fig. $2.54 \quad$ Evolution of pin isotopic content 
RUSSIAN RESEARCH CENTER KURCHATOV INSTITUTE

Design Studies of "Island" Type MOX Lead Test Assembly (Report for FY99)

Fig.3.1. Assembly-by-Assembly Burnup, Power and Temperature Drops Distributions. Equilibrium Cycle for Uranium Reference Core with Boron BPRs. Core $60^{\circ}$ Sector
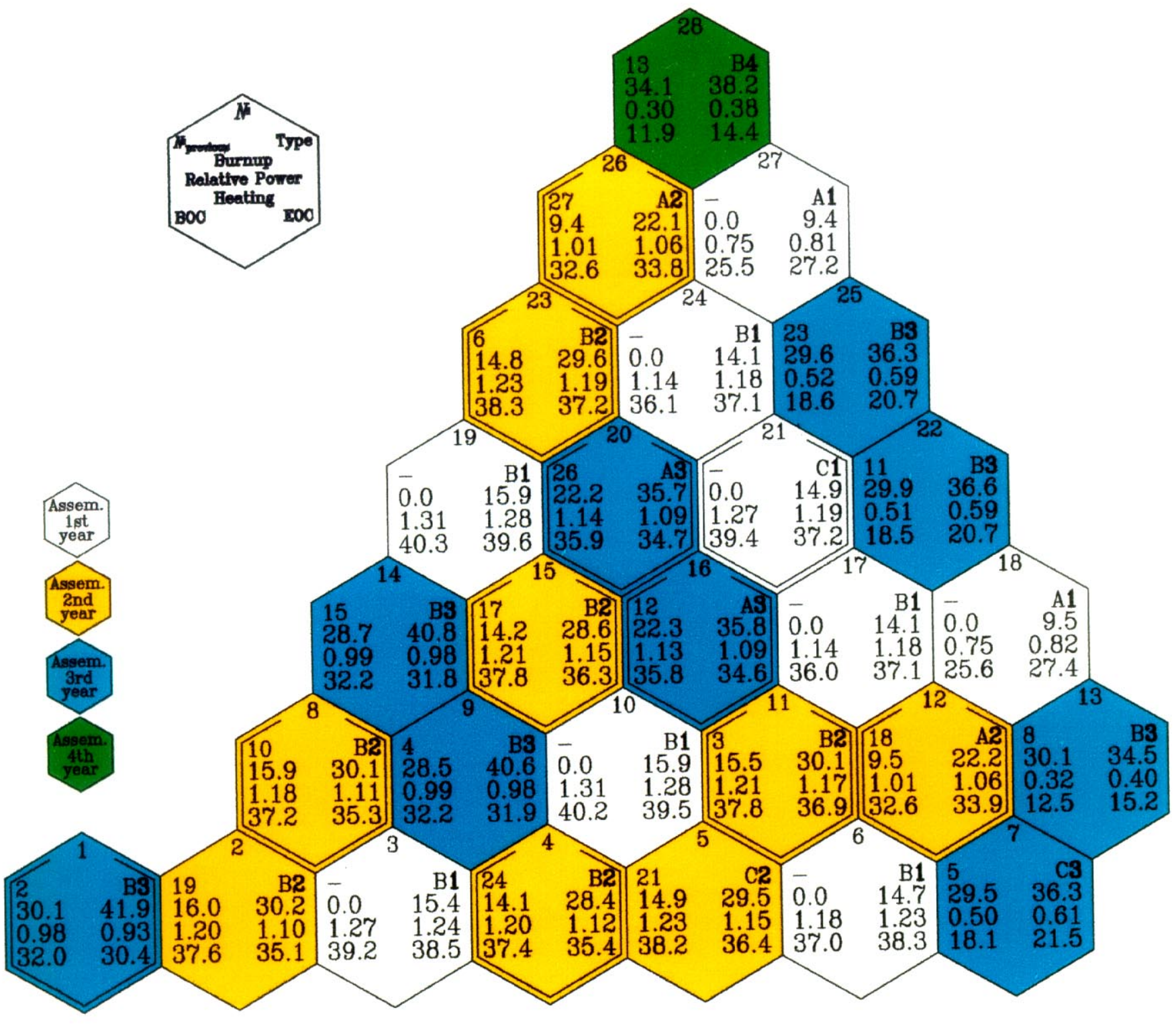


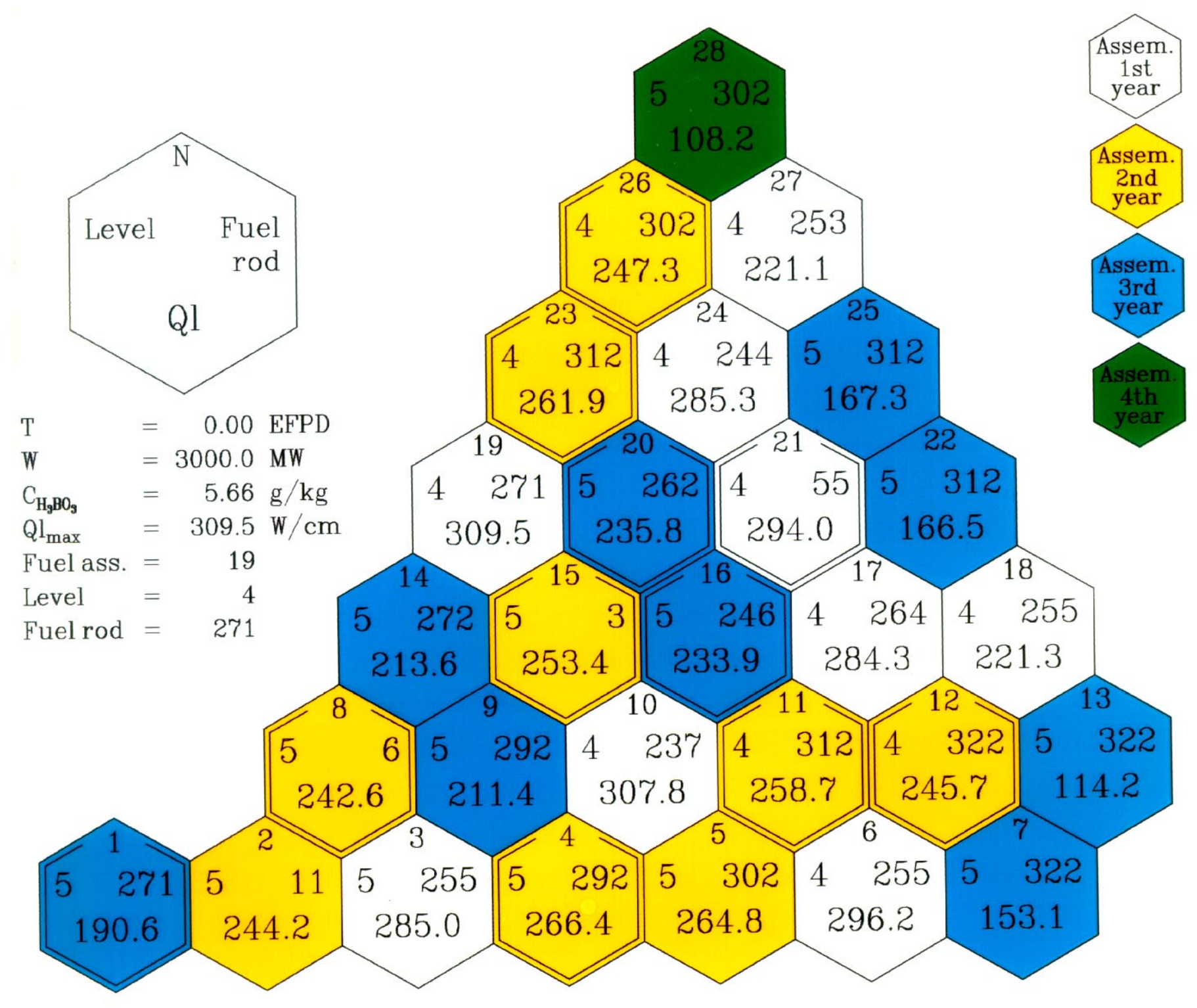




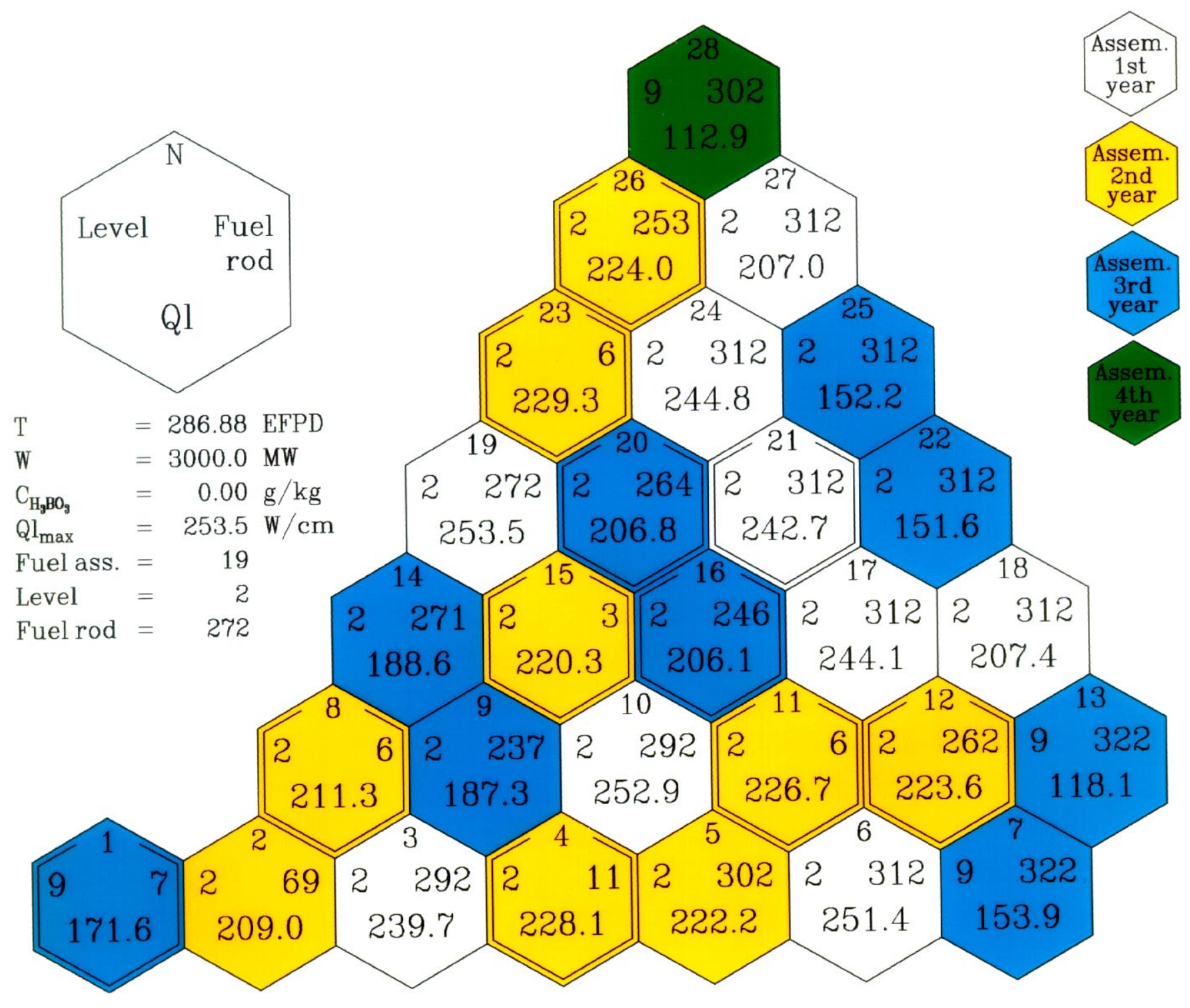


RUSSIAN RESEARCH CENTER KURCHATOV INSTITUTE

Design Studies of "Island" Type MOX Lead Test Assembly (Report for FY99)

Fig.3.4. Pin-by-Pin Power Distribution in the Most Powered Assembly in BOC. Equilibrium Cycle for Uranium Reference Core with Boron BPRs

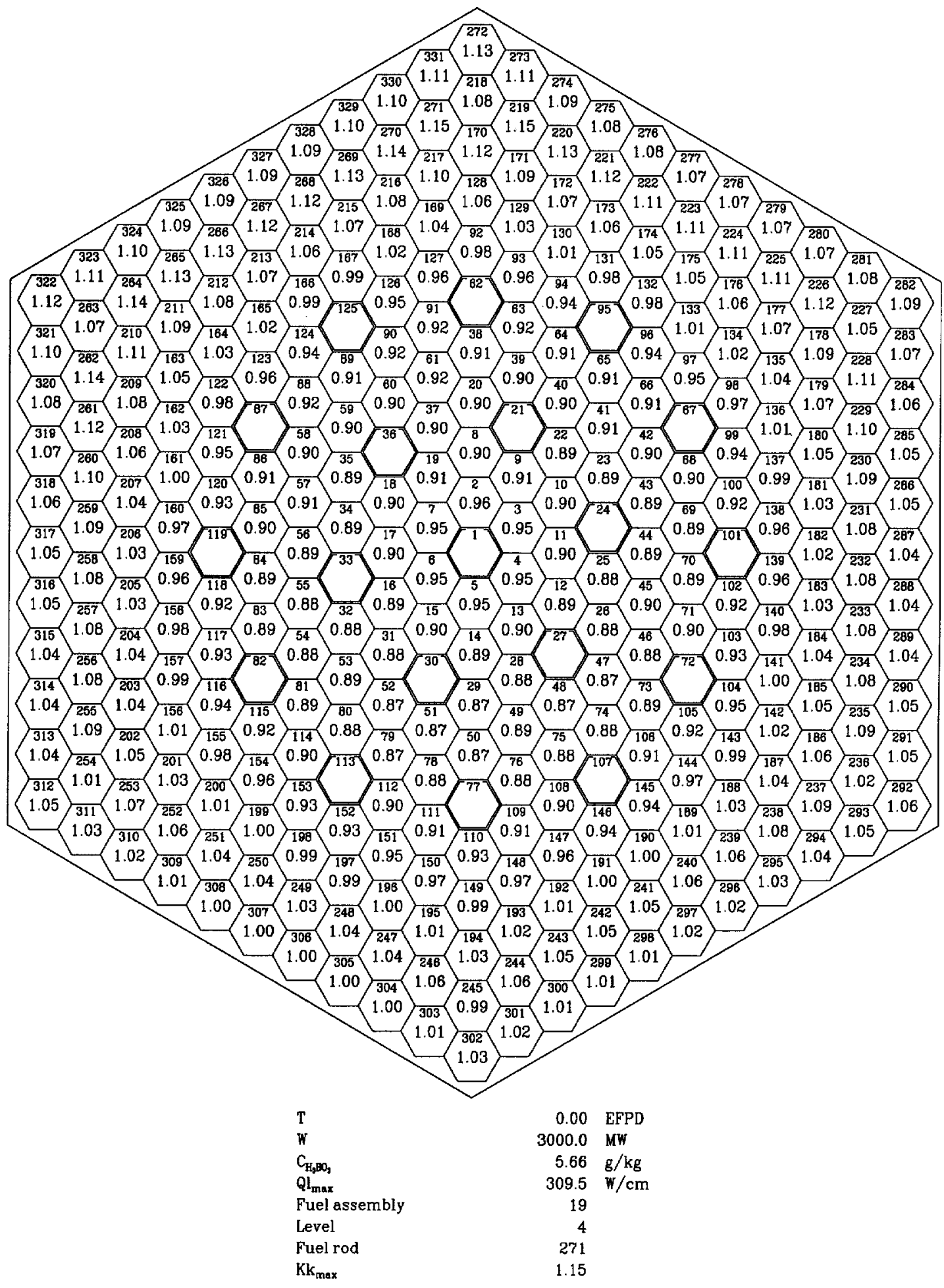




\section{RUSSIAN RESEARCH CENTER KURCHATOV INSTITUTE}

Design Studies of "Island" Type MOX Lead Test Assembly (Report for FY99)

Fig.3.5. Pin-by-Pin Power Distribution in the Most Powered Assembly in EOC. Equilibrium Cycle for Uranium Reference Core with Boron BPRs

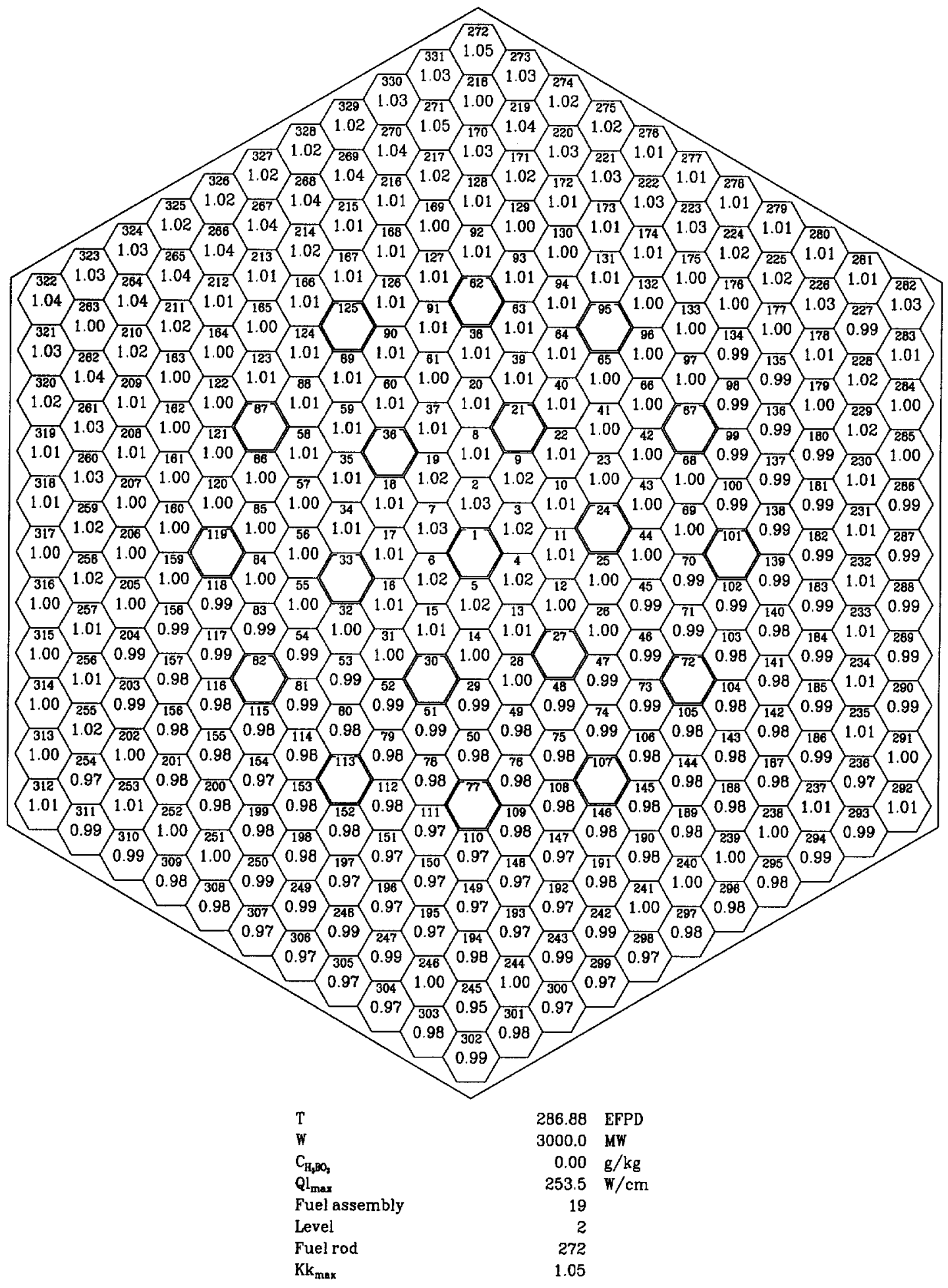


Figure 3.6. Control Rods Grouping and

\section{Positions of In-core Self-Powered Detectors}

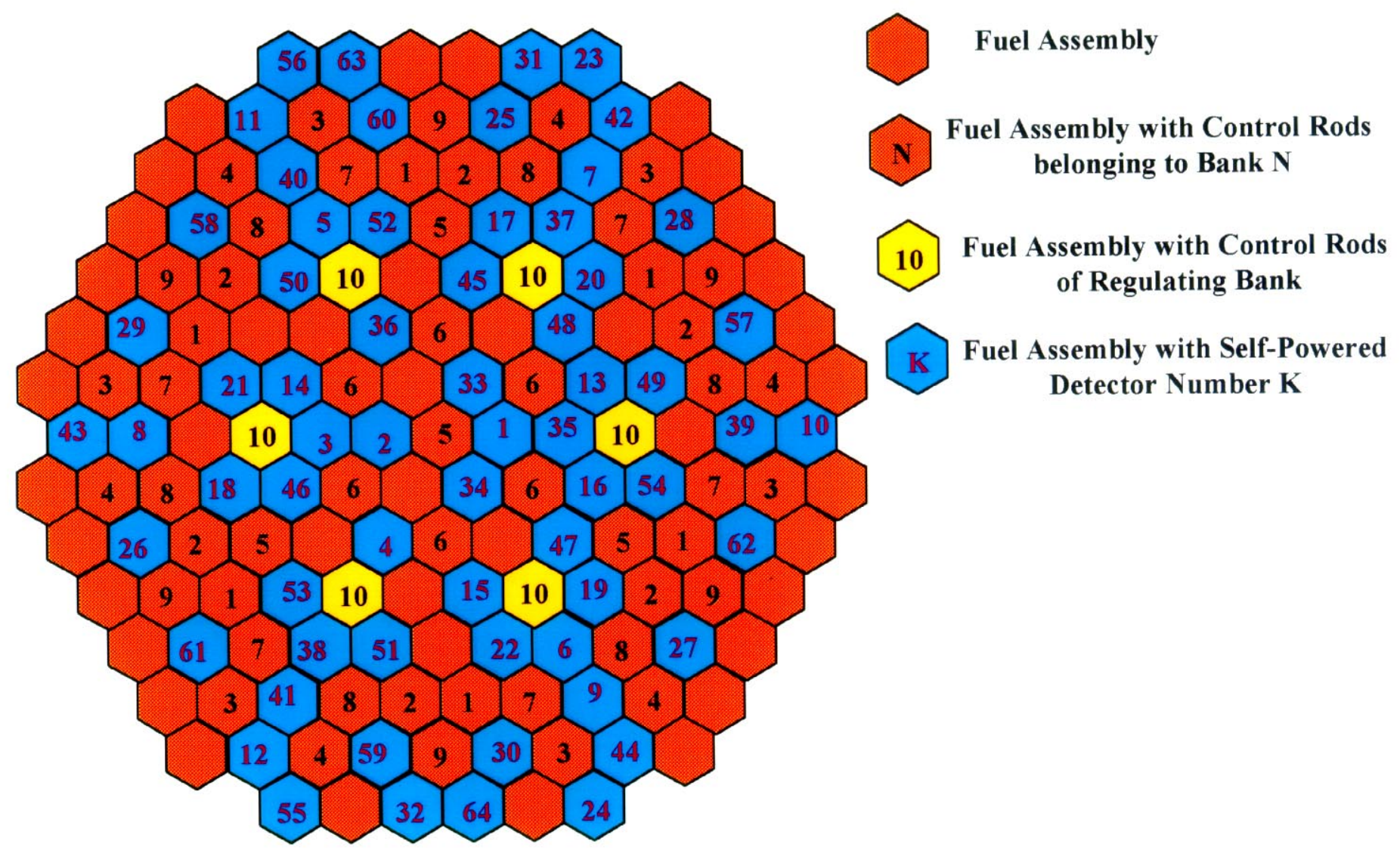

RRC KI. Design Studies of "Island" Type MOX Lead Test Assembly (Report for FY99) 
RUSSIAN RESEARCH CENTER KURCHATOV INSTITUTE

Design Studies of "Island" Type MOX Lead Test Assembly (Report for FY99)

Fig.3.7. Reloading Scheme.

First Cycle with 3 MOX LTAs

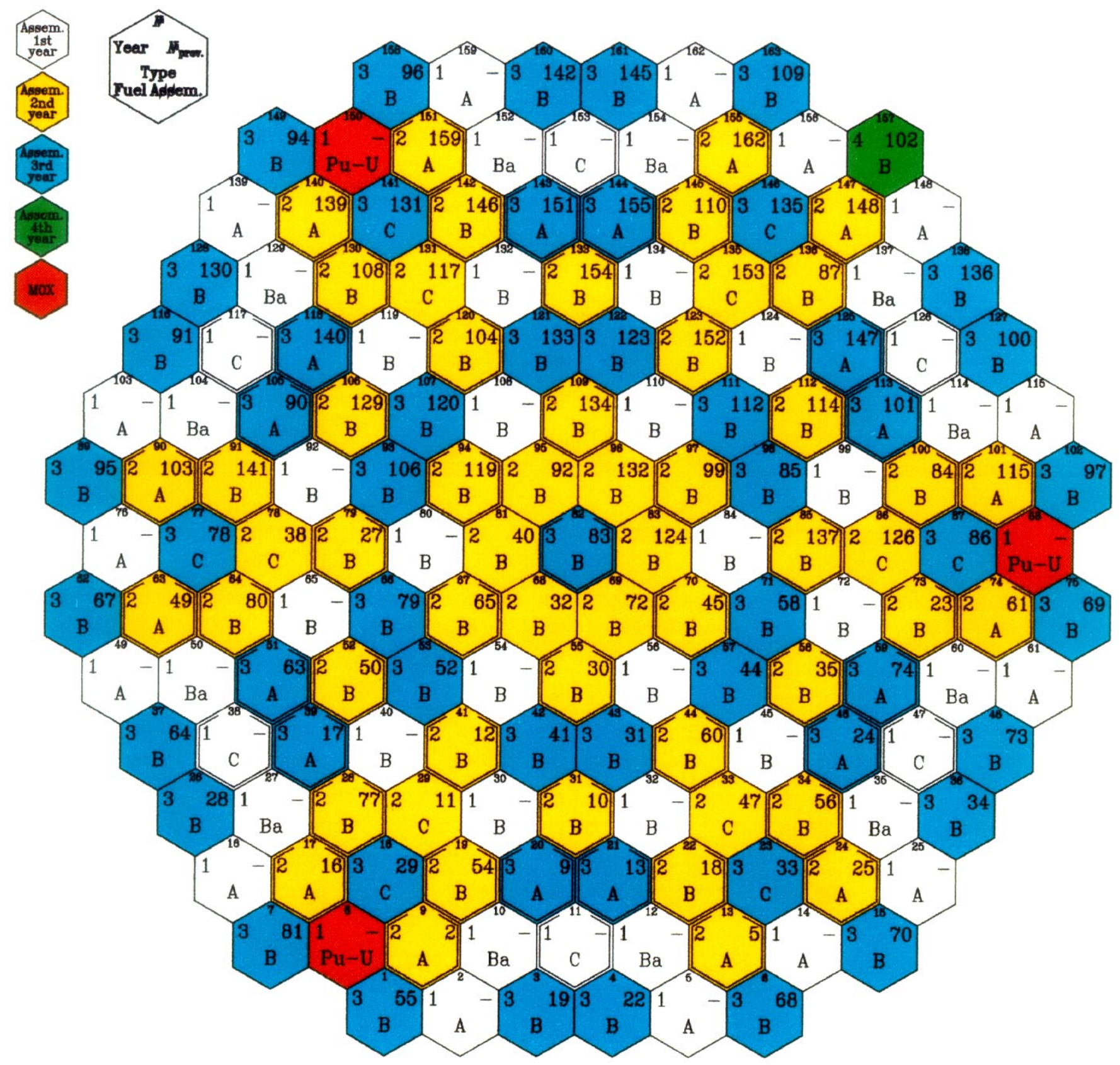


RUSSIAN RESEARCH CENTER KURCHATOV INSTITUTE

Design Studies of "Island" Type MOX Lead Test Assembly (Report for FY99)

Fig.3.8. Assembly-by-Assembly Power Distribution.

First Cycle with 3 MOX LTAs of "lsland-2" Type (Pu3.8-2.8, U-3.7)

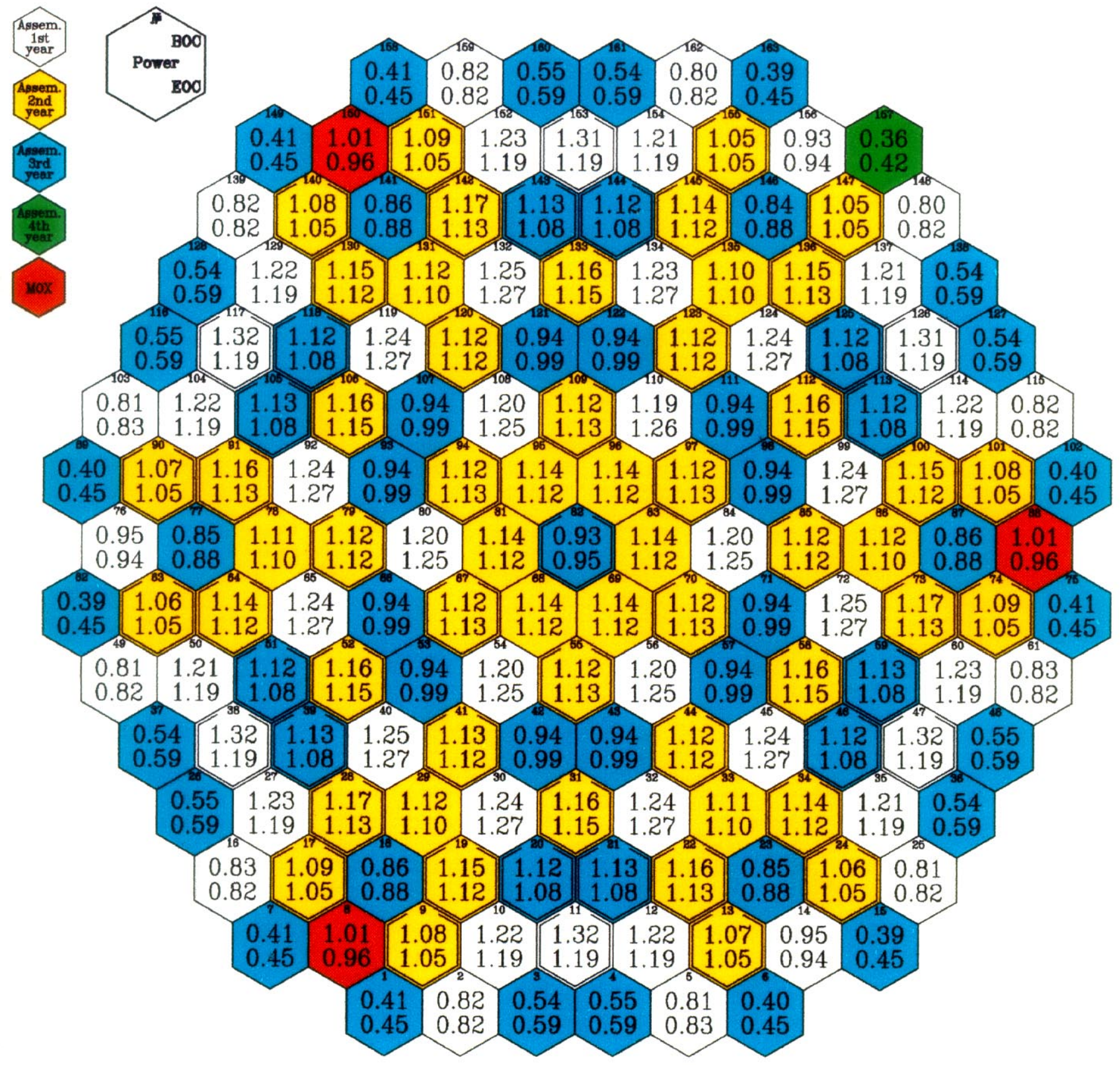


RUSSIAN RESEARCH CENTER KURCHATOV INSTITUTE

Design Studies of "Island" Type MOX Lead Test Assembly (Report for FY99)

Fig.3.9. Assembly-by-Assembly Burnup Distribution.

First Cycle with 3 MOX LTAs of alsland-2w Type (Pu3.8-2.8, U-3.7)

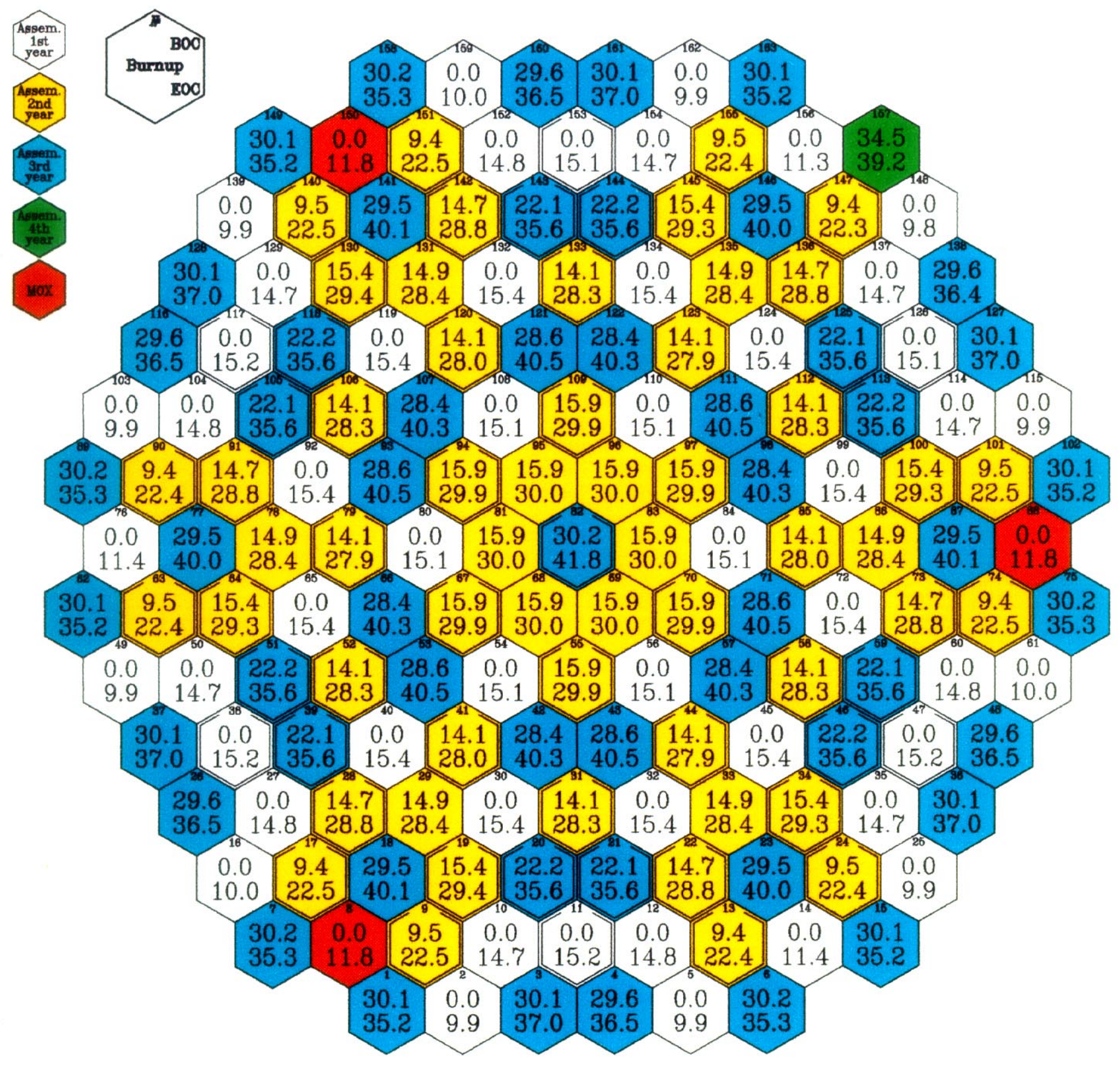


RUSSIAN RESEARCH CENTER KURCHATOV INSTITUTE

Design Studies of "Island" Type MOX Lead Test Assembly (Report for FY99)

Fig.3.10. Assembly-by-Assembly Temperature Drop Distribution.

First Cycle with 3 MOX LTAs of alsland-2" Type (Pu3.8-2.8, U-3.7)

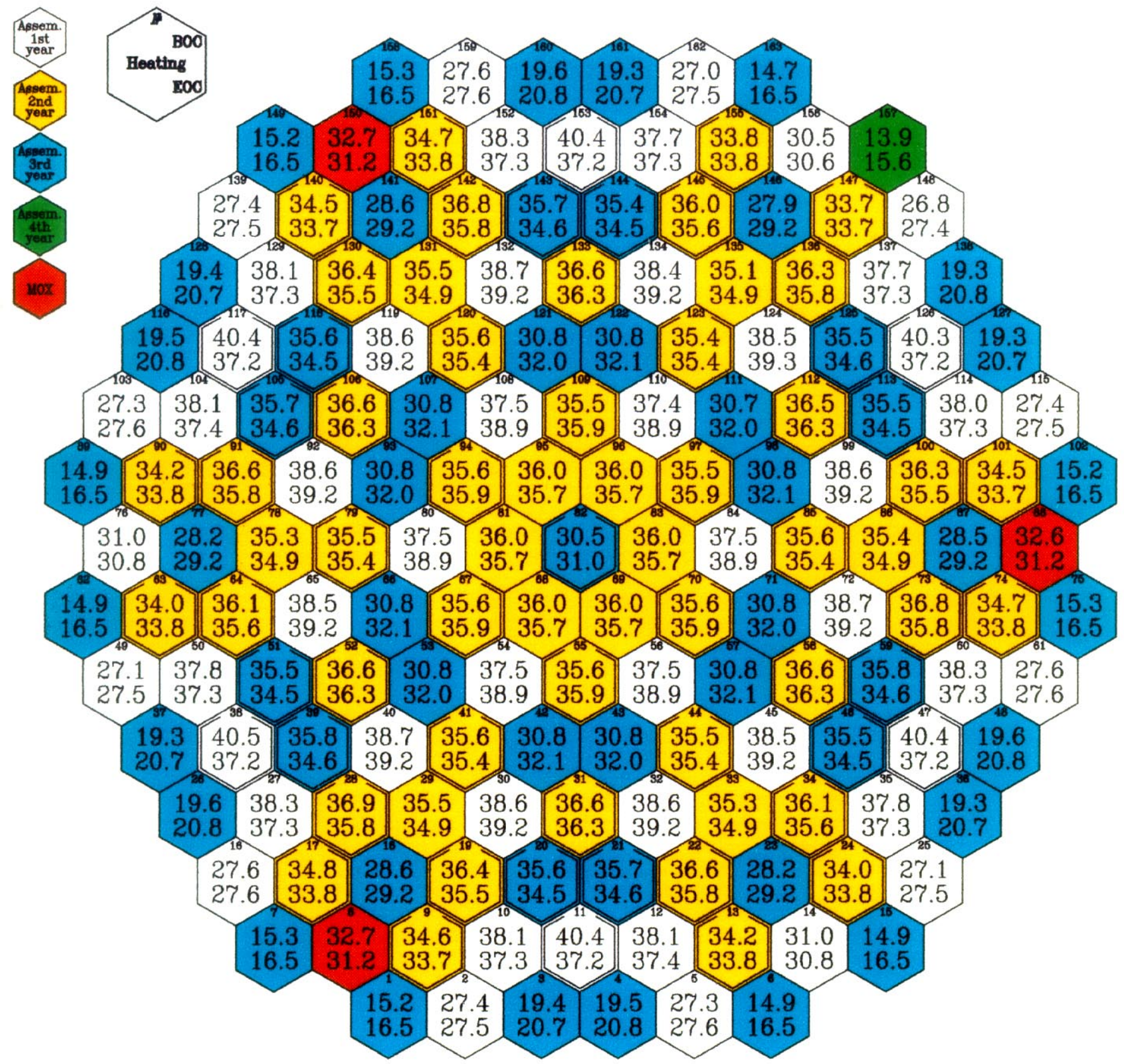


RUSSIAN RESEARCH CENTER KURCHATOV INSTITUTE

Design Studies of "Island" Type MOX Lead Test Assembly (Report for FY99)

Fig.3.11. Assembly-by-Assembly Maximum Linear Power Distribution in BOC.

First Cycle with 3 MOX LTAs of «/sland-2" Type (Pu3.8-2.8-U3.7)

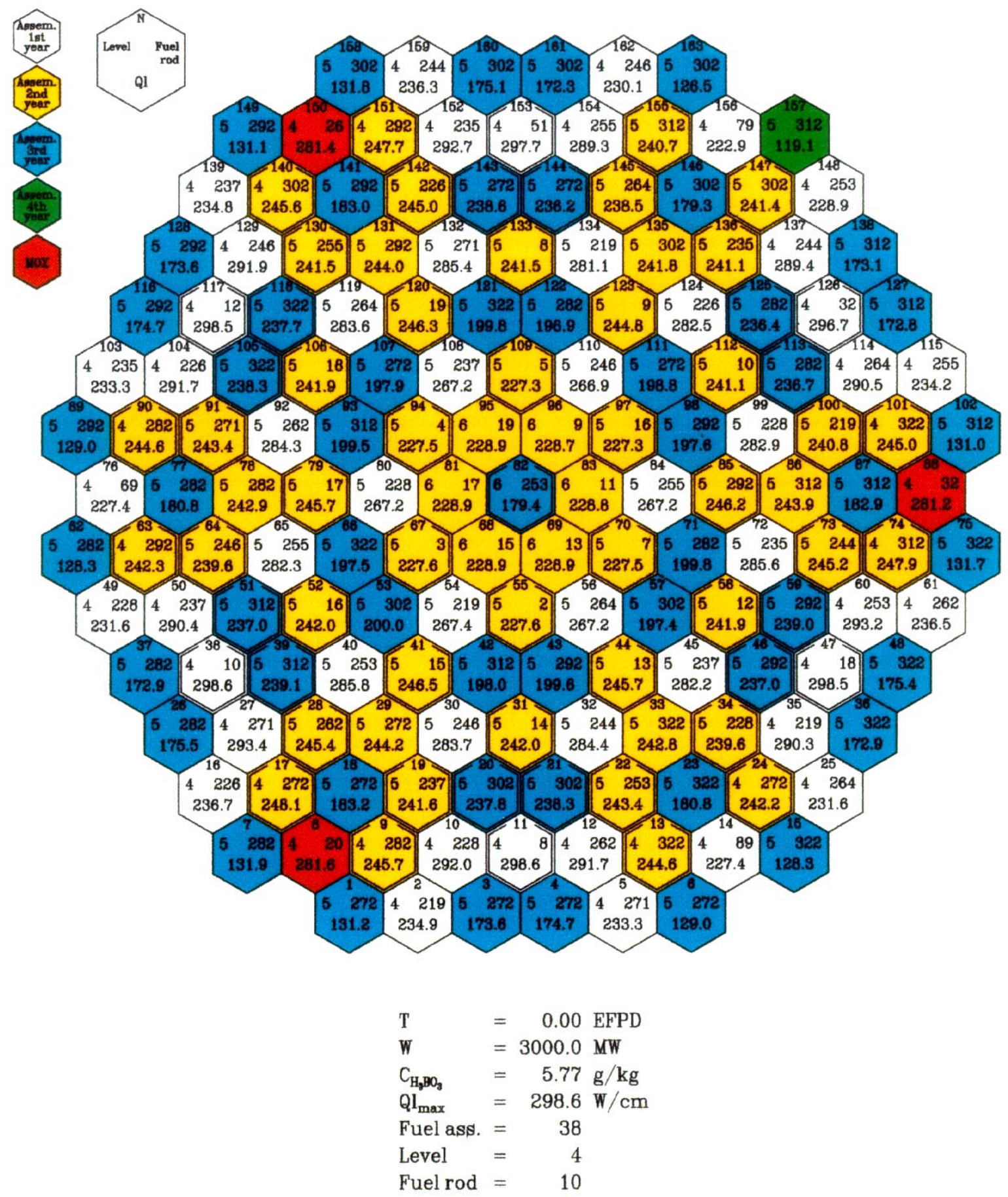


RUSSIAN RESEARCH CENTER KURCHATOV INSTITUTE

Design Studies of "Island" Type MOX Lead Test Assembly (Report for FY99)

Fig.3.12. Assembly-by-Assembly Maximum Linear Power Distribution in EOC. First Cycle with 3 MOX LTAs 100\%Pu (Pu3.8-2.8-U3.7)

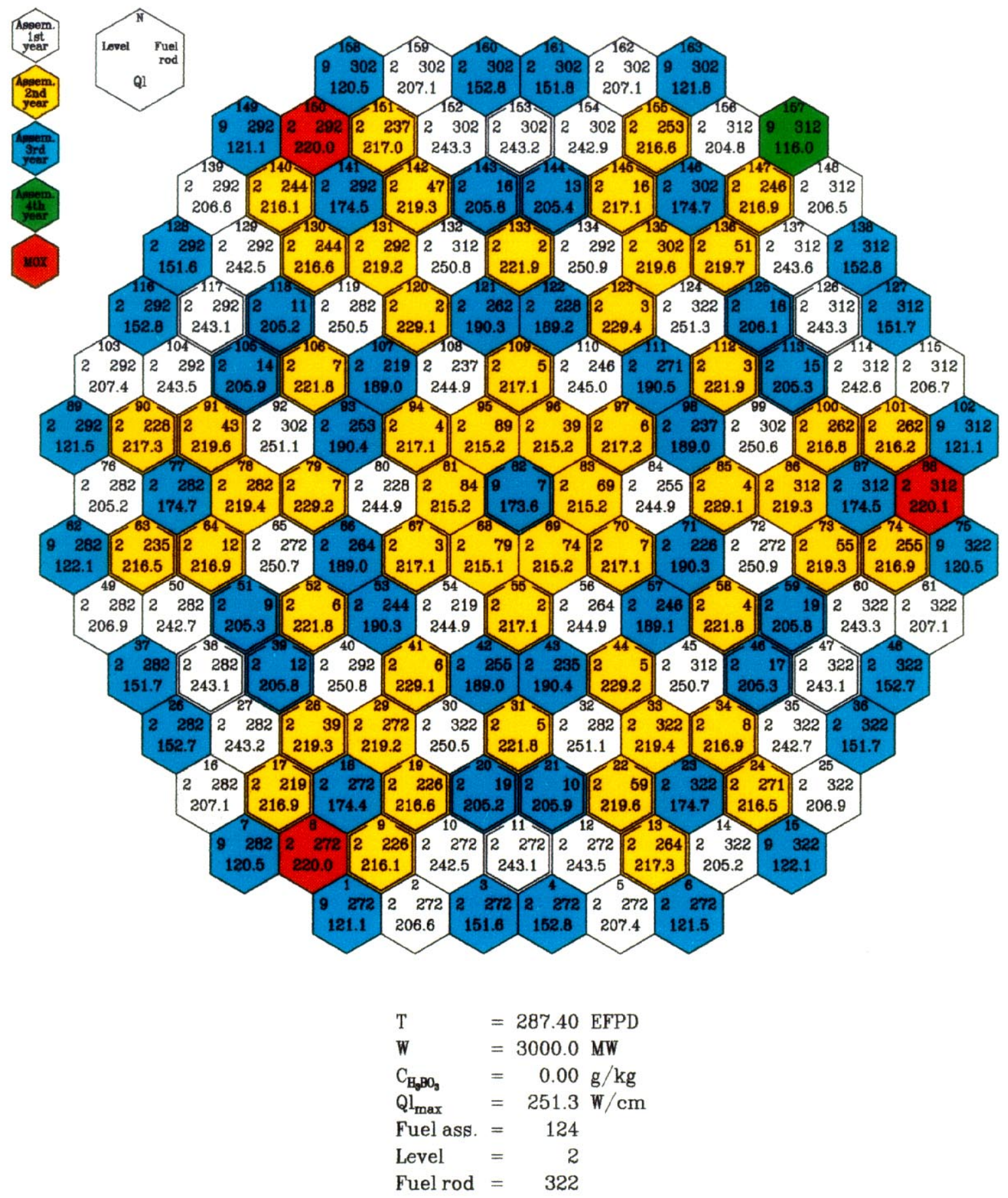


RUSSIAN RESEARCH CENTER KURCHATOV INSTITUTE

Design Studies of "Island" Type MOX Lead Test Assembly (Report for FY99)

Fig.3.13. Pin-by-Pin Power Distribution in the Most Powered Assembly in BOC. First Cycle with 3 MOX LTAs of «Island-2» Type (Pu3.8-2.8, U-3.7)

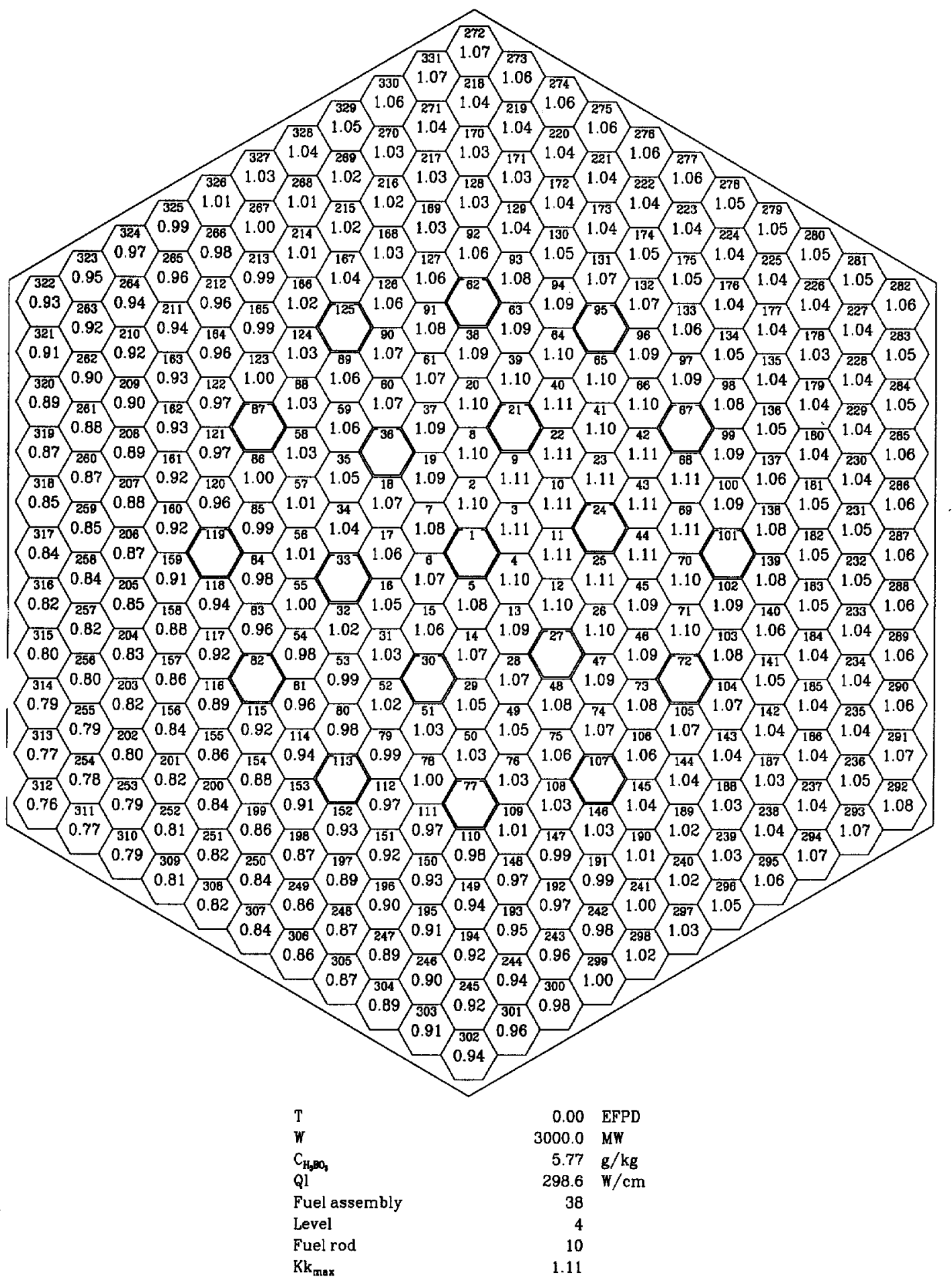


RUSSIAN RESEARCH CENTER KURCHATOY INSTITUTE

Design Studies of "Island" Type MOX Lead Test Assembly (Report for FY99)

Fig.3.14. Pin-by-Pin Power Distribution in the Most Powered Assembly in EOC. First Cycle with 3 MOX LTAs of «lsland-2» Type (Pu3.8-2.8, U-3.7)

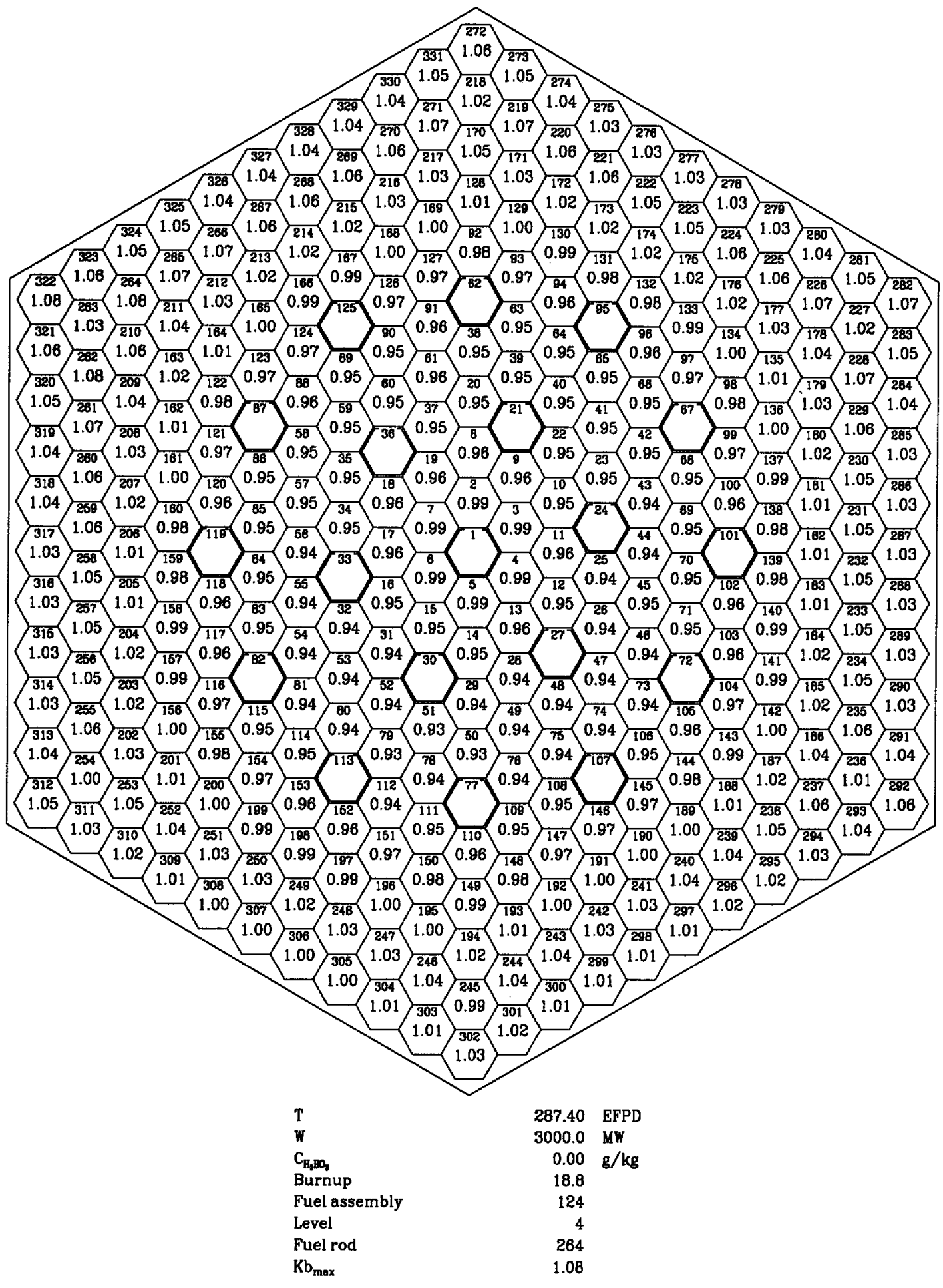


RUSSIAN RESEARCH CENTER KURCHATOV INSTITUTE

Design Studies of "Island" Type MOX Lead Test Assembly (Report for FY99)

Fig.3.15. Pin-by-Pin Power Distribution in MOX LTA in BOC. First Cycle with 3 MOX LTAs of «lsland-2» Type (Pu3.8-2.8, U-3.7)

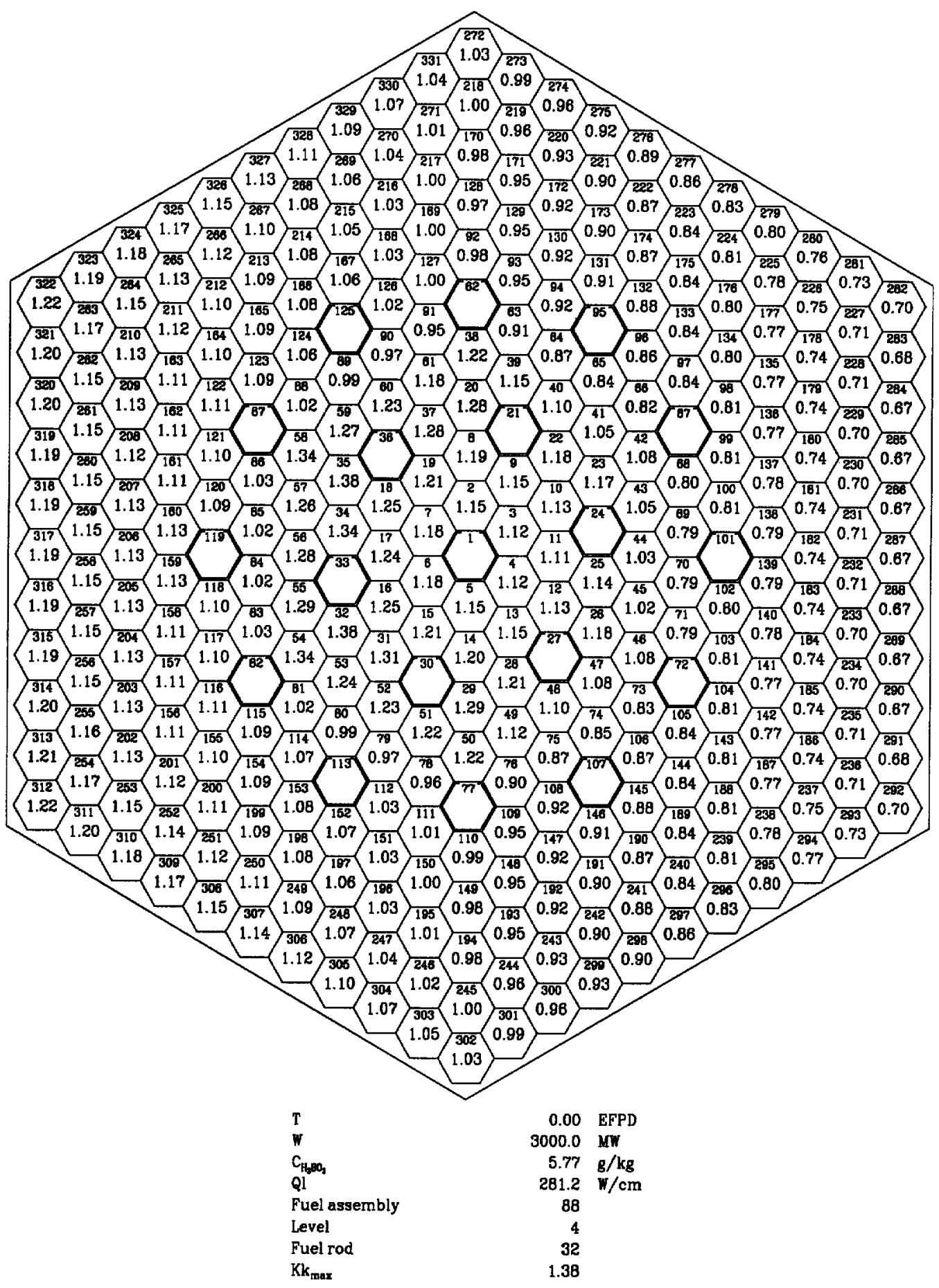


RUSSIAN RESEARCH CENTER KURCHATOV INSTITUTE

Design Studies of "Island" Type MOX Lead Test Assembly (Report for FY99)

Fig.3.16. Pin-by-Pin Power Distribution in MOX LTA in EOC. First Cycle with 3 MOX LTAs of «lsland-2» Type (Pu3.8-2.8, U-3.7)

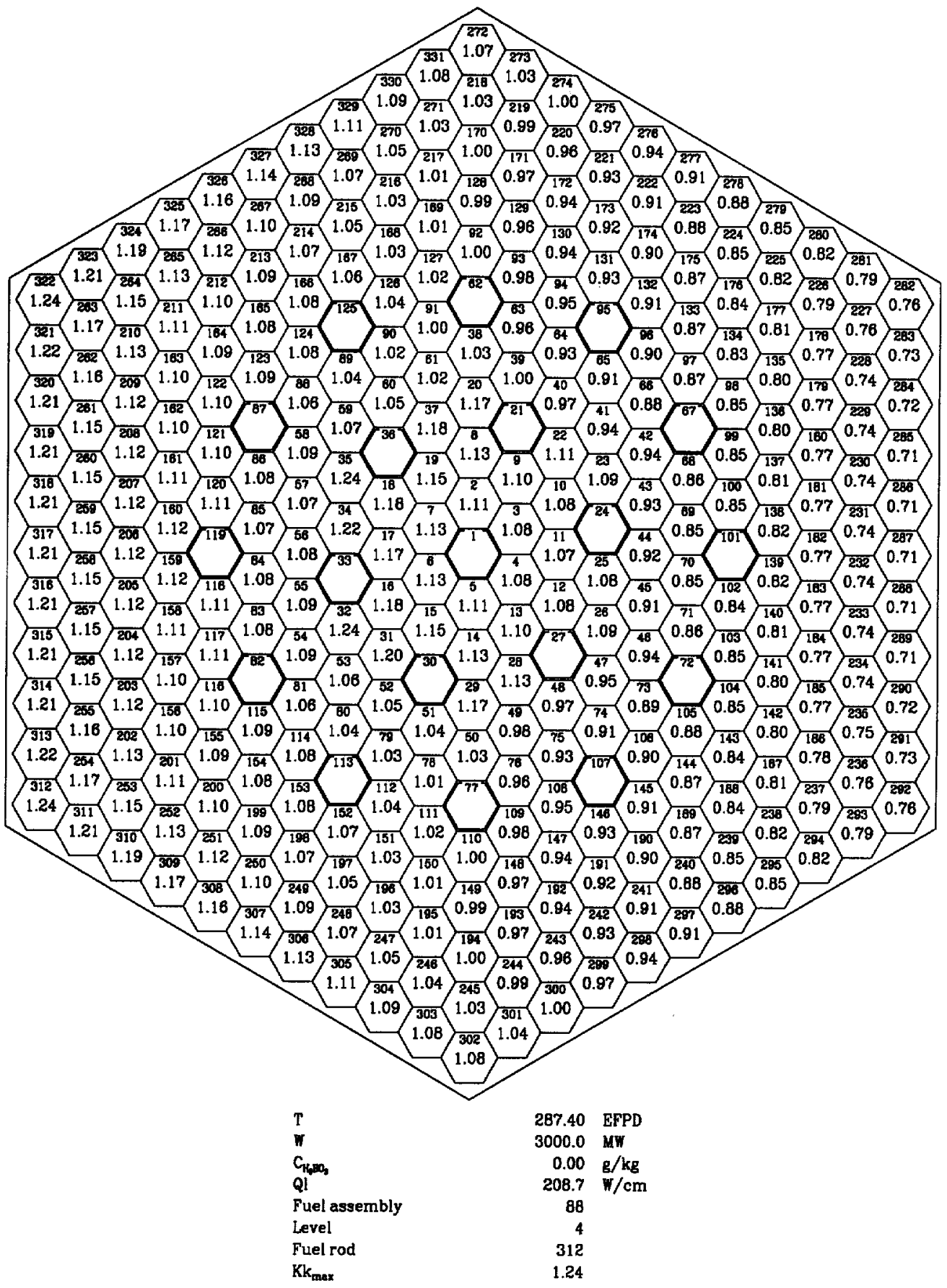


RUSSIAN RESEARCH CENTER KURCHATOV INSTITUTE

Design Studies of "Island" Type MOX Lead Test Assembly (Report for FY99)

Fig.3.17. Reloading Scheme.

Second Cycle with 3 MOX LTAs

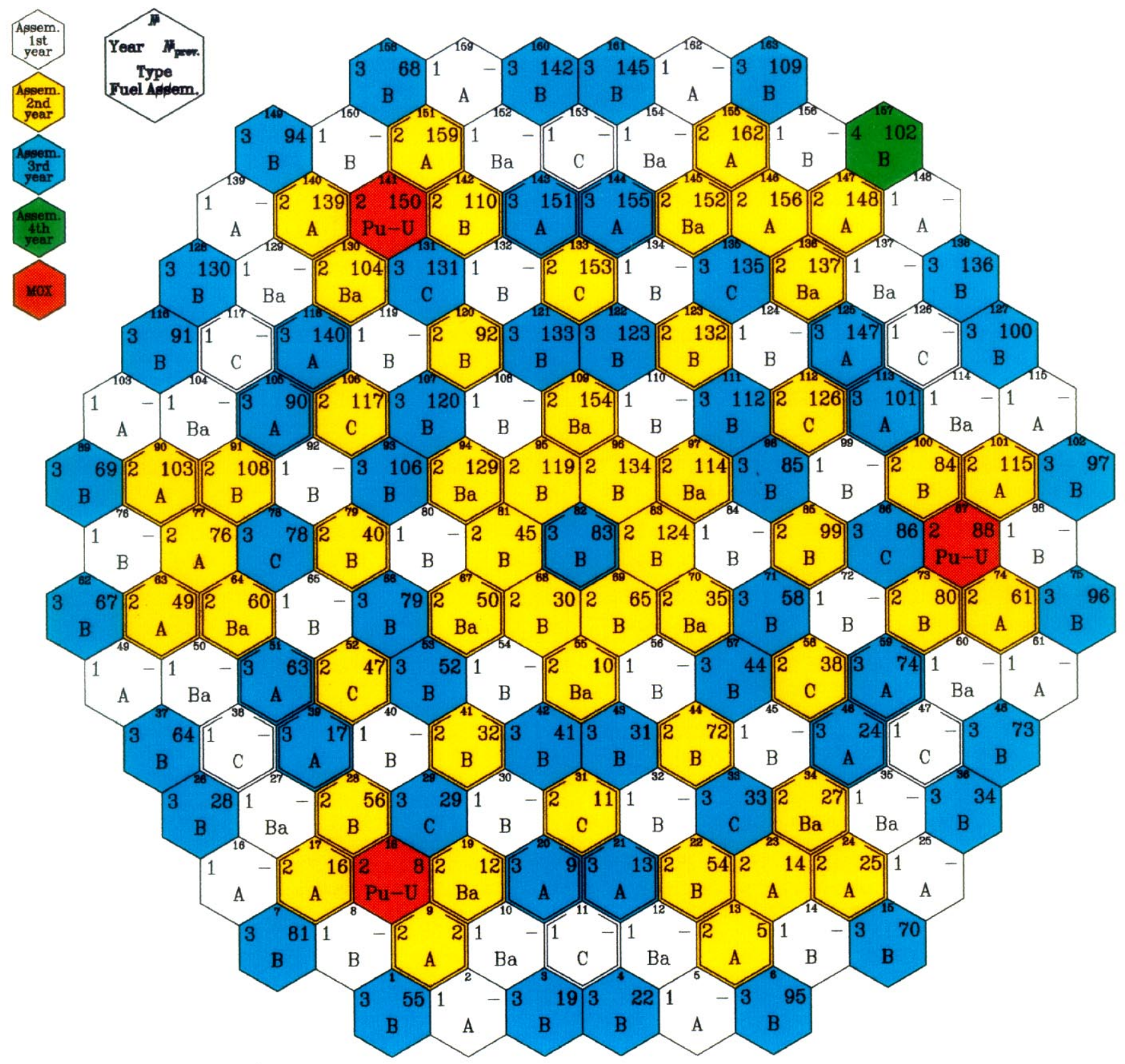


RUSSIAN RESEARCH CENTER KURCHATOV INSTITUTE

Design Studies of "Island" Type MOX Lead Test Assembly (Report for FY99)

Fig.3.18. Assembly-by-Assembly Power Distribution.

Second Cycle with 3 MOX LTAs of «Island-2» Type (Pu3.8-2.8-U3.7)

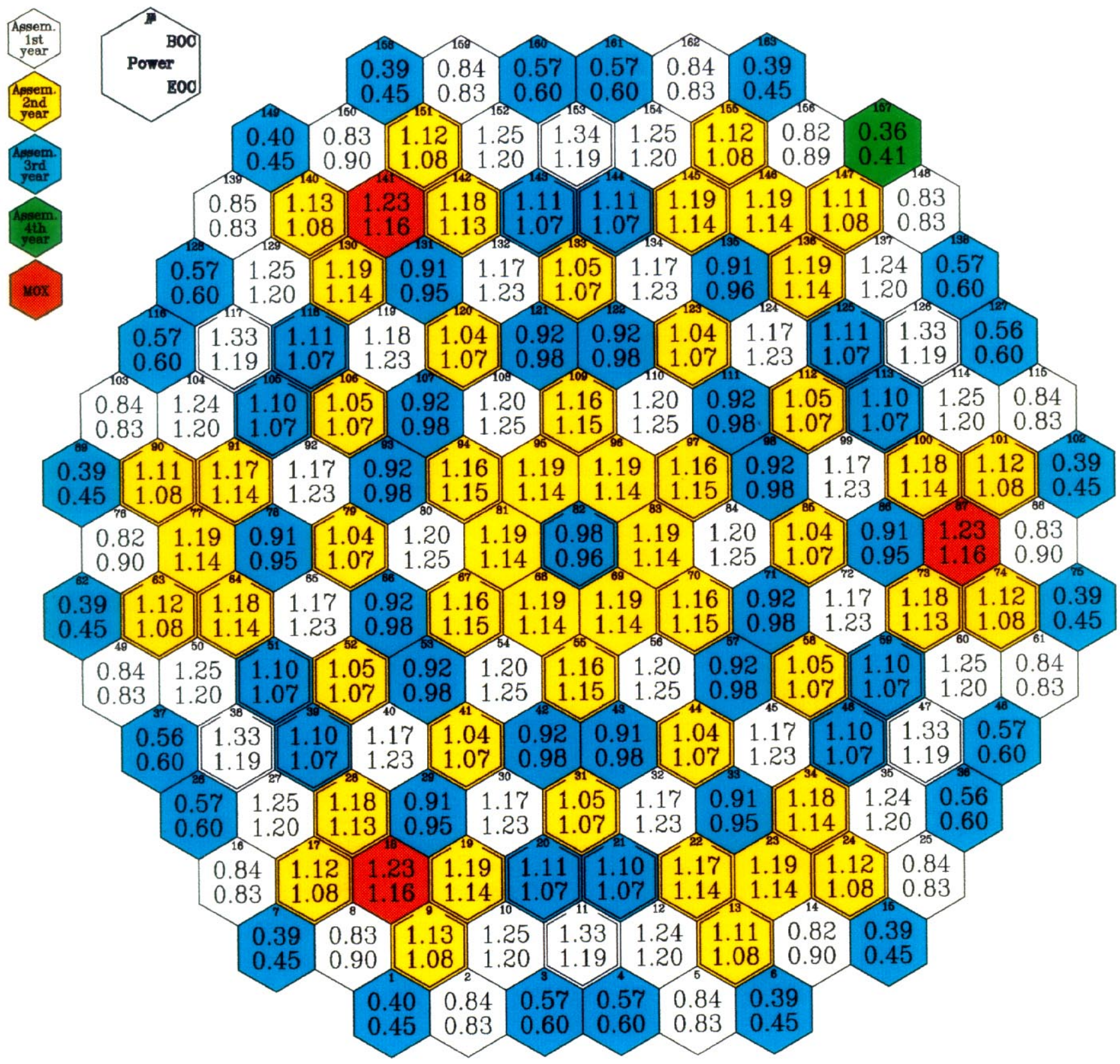


RUSSIAN RESEARCH CENTER KURCHATOV INSTITUTE

Design Studies of "Island" Type MOX Lead Test Assembly (Report for FY99)

Fig.3.19. Assembly-by-Assembly Burnup Distribution.

Second Cycle with 3 MOX LTAs of «lsland-2» Type (Pu3.8-2.8-U3.7)

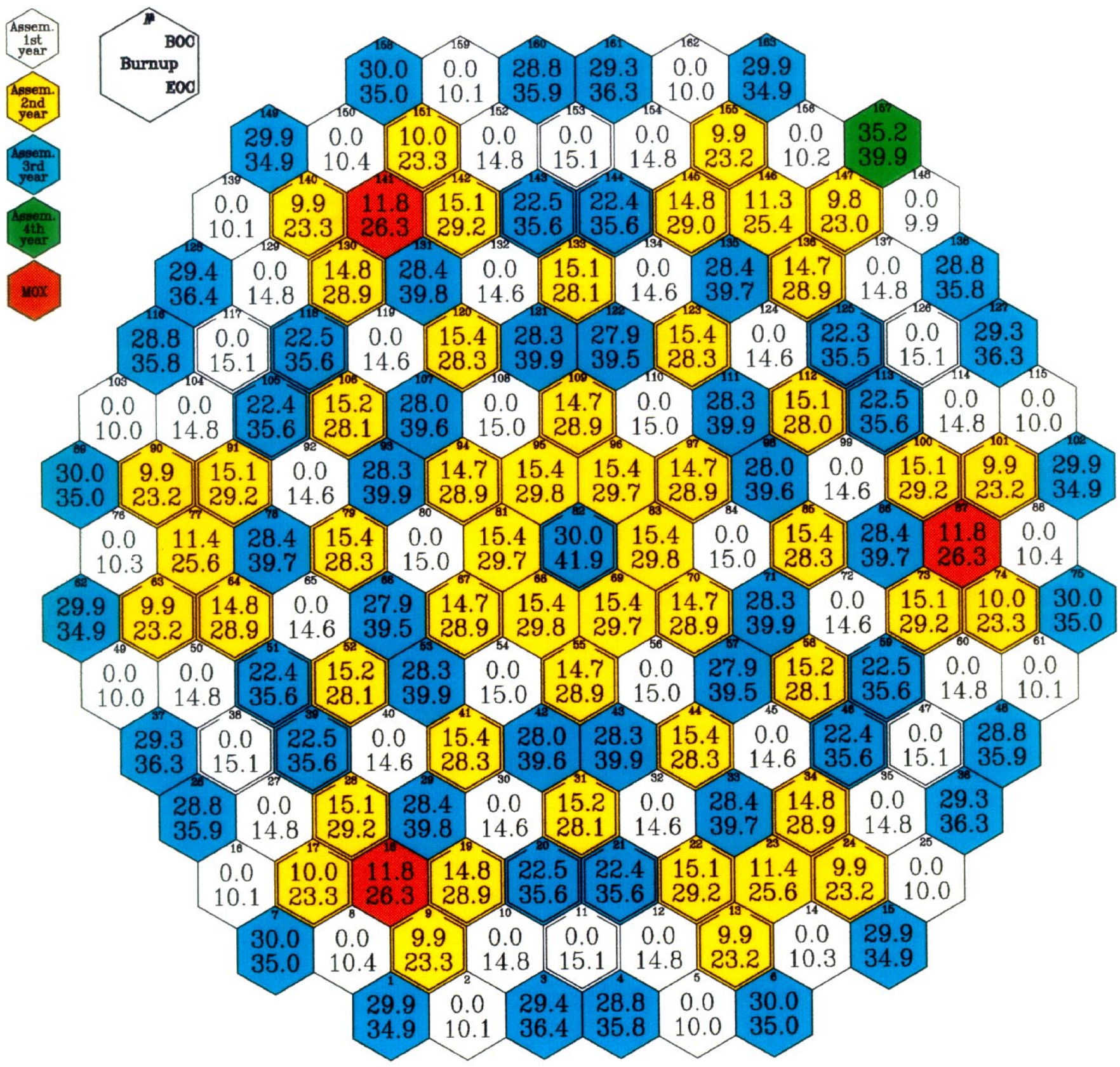


RUSSIAN RESEARCH CENTER KURCHATOV INSTITUTE

Design Studies of "Island" Type MOX Lead Test Assembly (Report for FY99)

Fig.3.20. Assembly-by-Assembly Temperature Drop Distribution.

Second Cycle with 3 MOX LTAs of «lsland-2» Type (Pu3.8-2.8-U3.7)

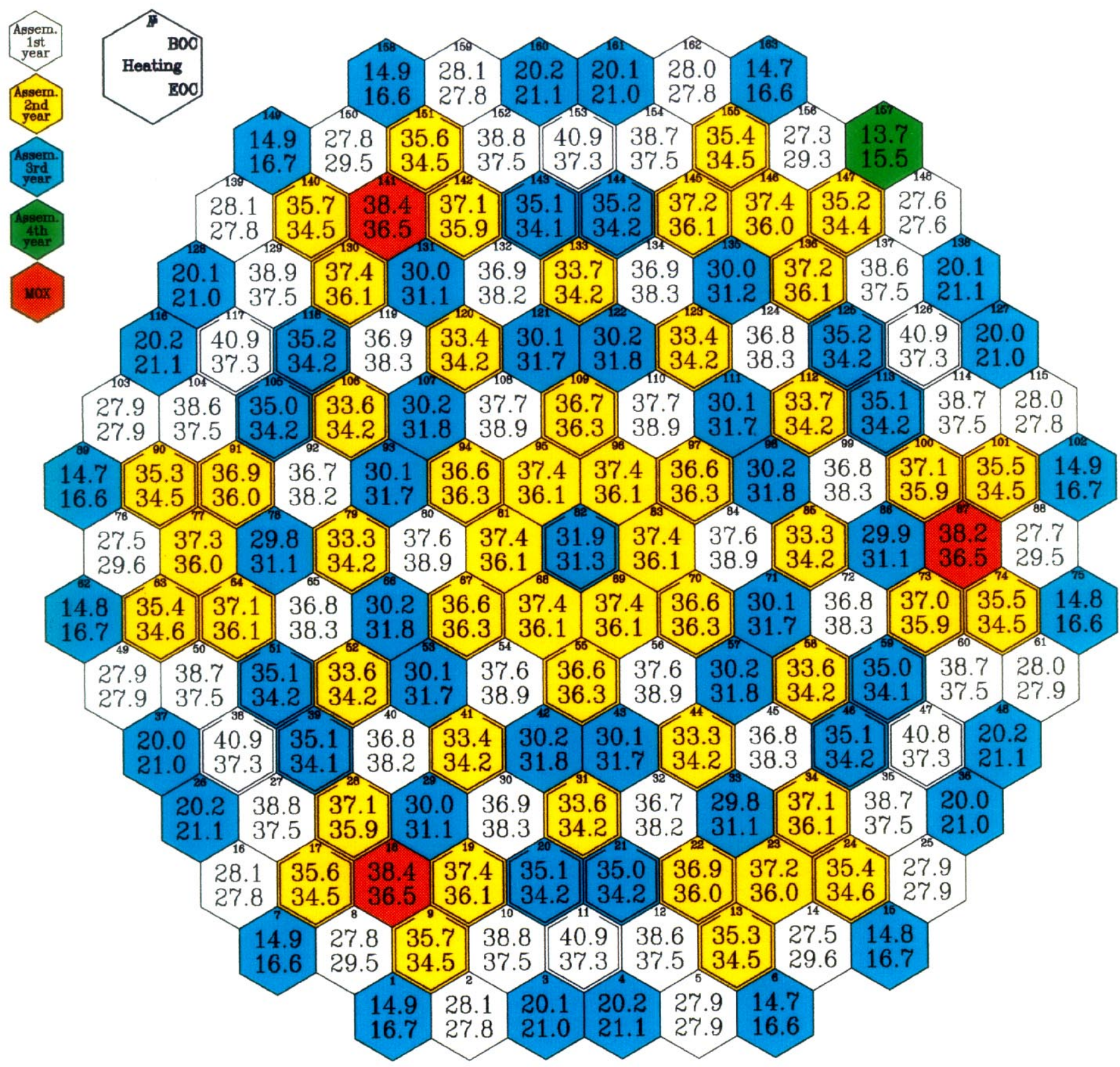


RUSSIAN RESEARCH CENTER KURCHATOV INSTITUTE

Design Studies of "Island" Type MOX Lead Test Assembly (Report for FY99)

Fig.3.21. Assembly-by-Assembly Maximum Linear Pin Power Distribution in BOC. Second Cycle with 3 MOX LTAs of «lsland-2» Type (Pu3.8-2.8-U3.7)

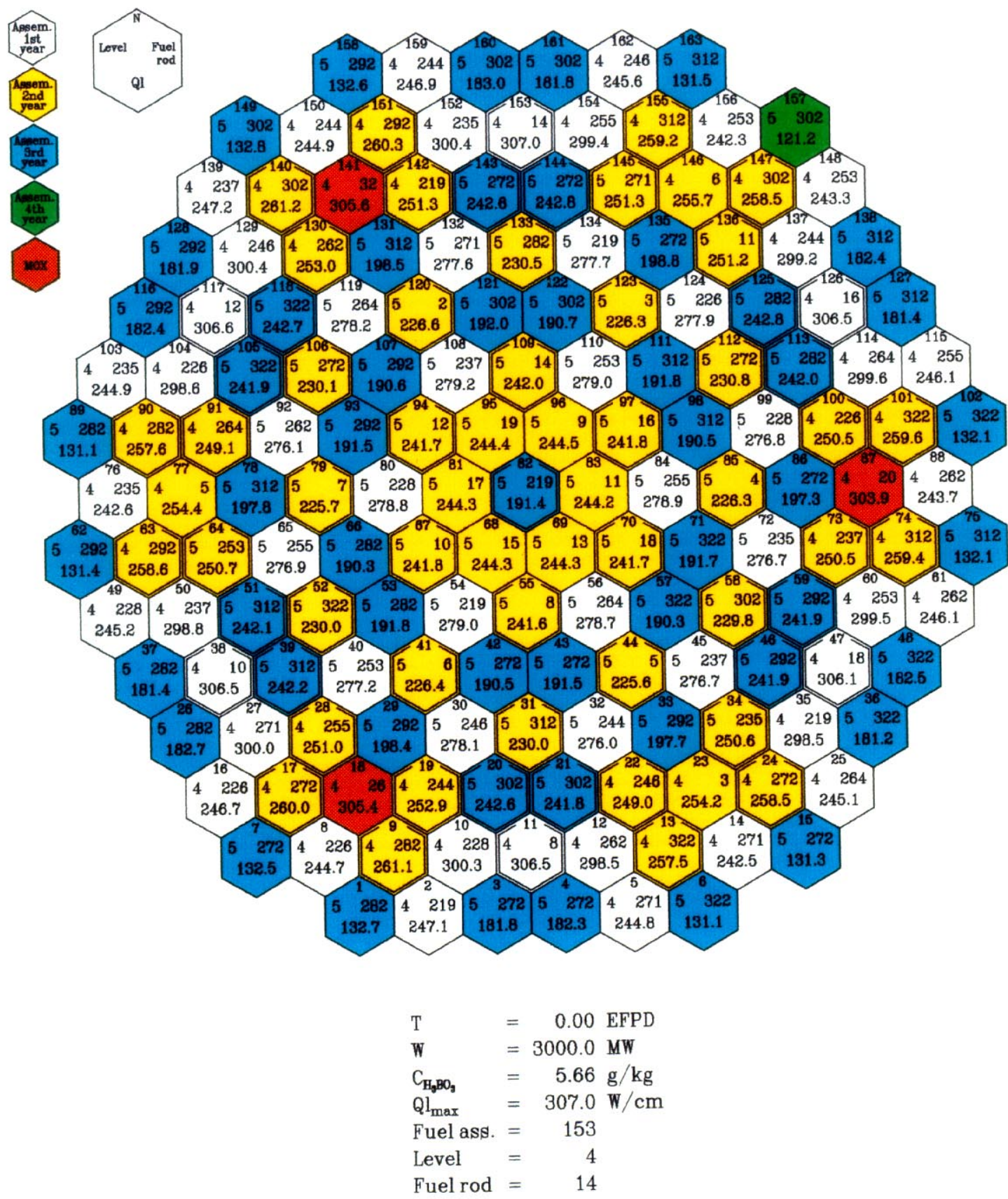


RUSSIAN RESEARCH CENTER KURCHATOV INSTITUTE

Design Studies of "Island" Type MOX Lead Test Assembly (Report for FY99)

Fig.3.22. Assembly-by-Assembly Maximum Linear Pin Power Distribution in EOC. Second Cycle with 3 MOX LTAs of «Island-2» Type (Pu3.8-2.8-U3.7)

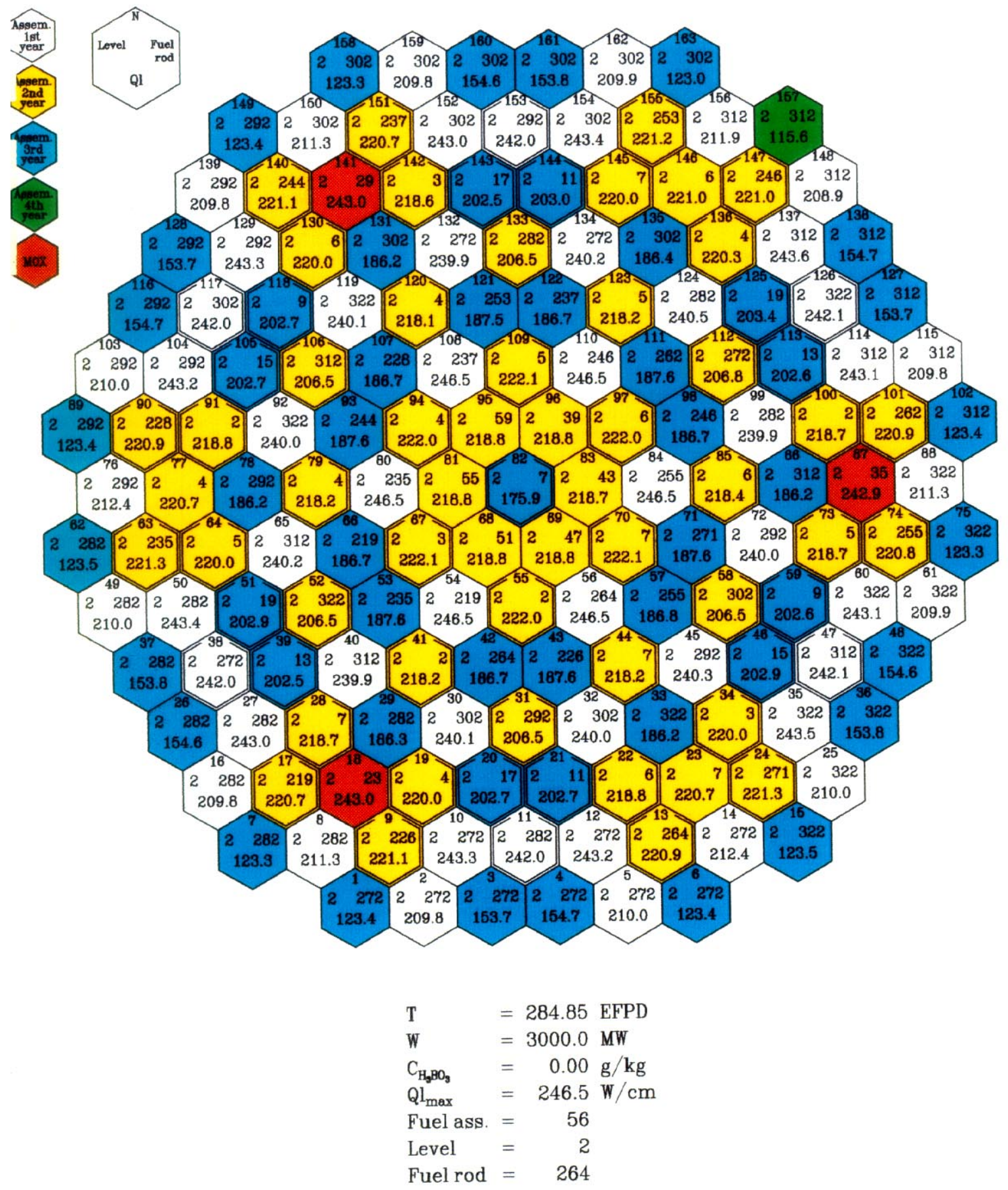


RUSSIAN RESEARCH CENTER KURCHATOV INSTITUTE

Design Studies of "Island" Type MOX Lead Test Assembly (Report for FY99)

Fig.3.23. Pin-by-Pin Power Distribution in the Most Powered Assembly in BOC. Second Cycle with 3 MOX LTAs of alsland-2" Type (Pu3.8-2.8-U3.7)

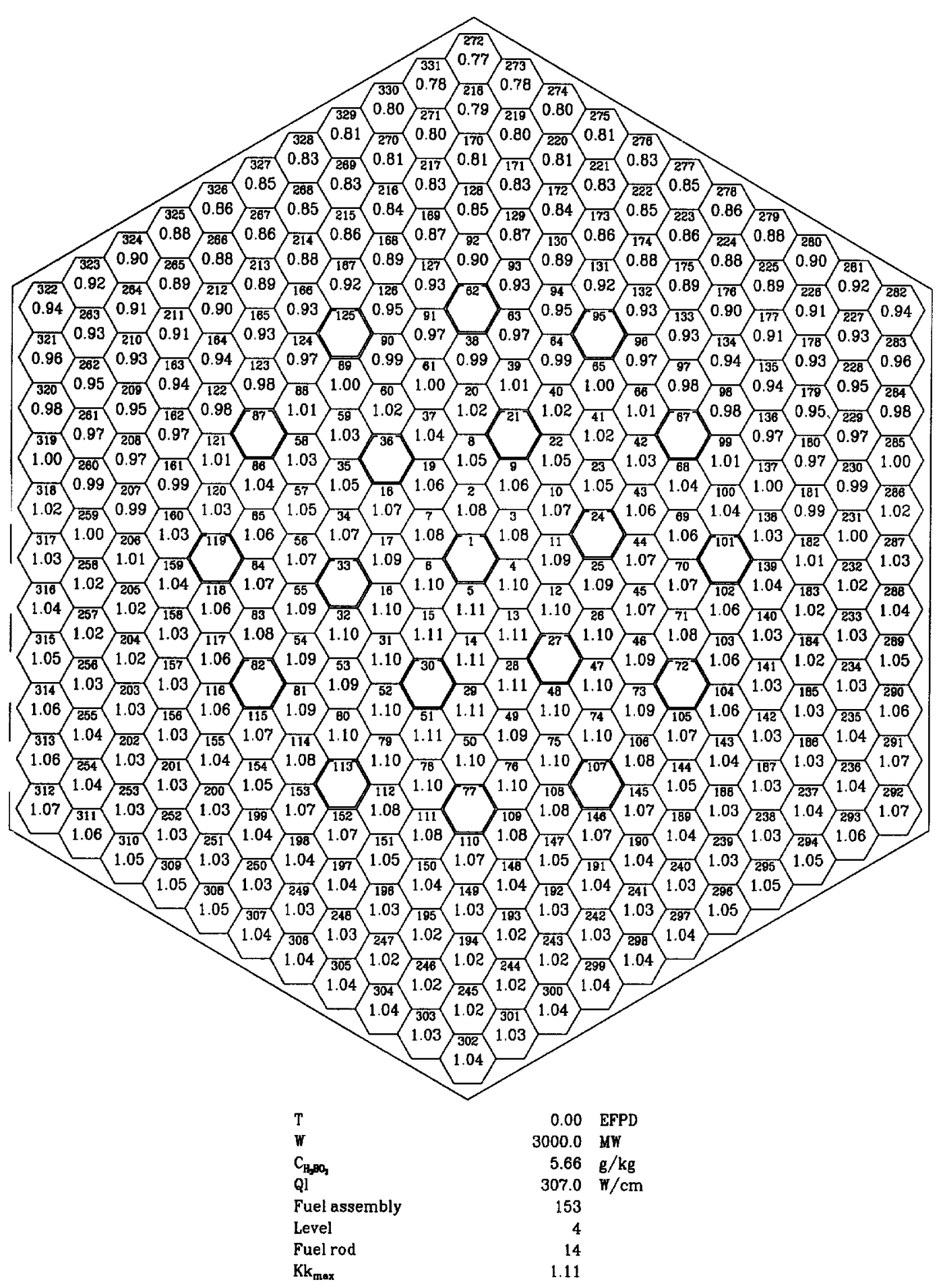


RUSSIAN RESEARCH CENTER KURCHATOV INSTITUTE

Design Studies of "Island" Type MOX Lead Test Assembly (Report for FY99)

Fig.3.24. Pin-by-Pin Power Distribution in the Most Powered Assembly in EOC. Second Cycle with 3 MOX LTAs of "Island-2" Type (Pu3.8-2.8-U3.7)

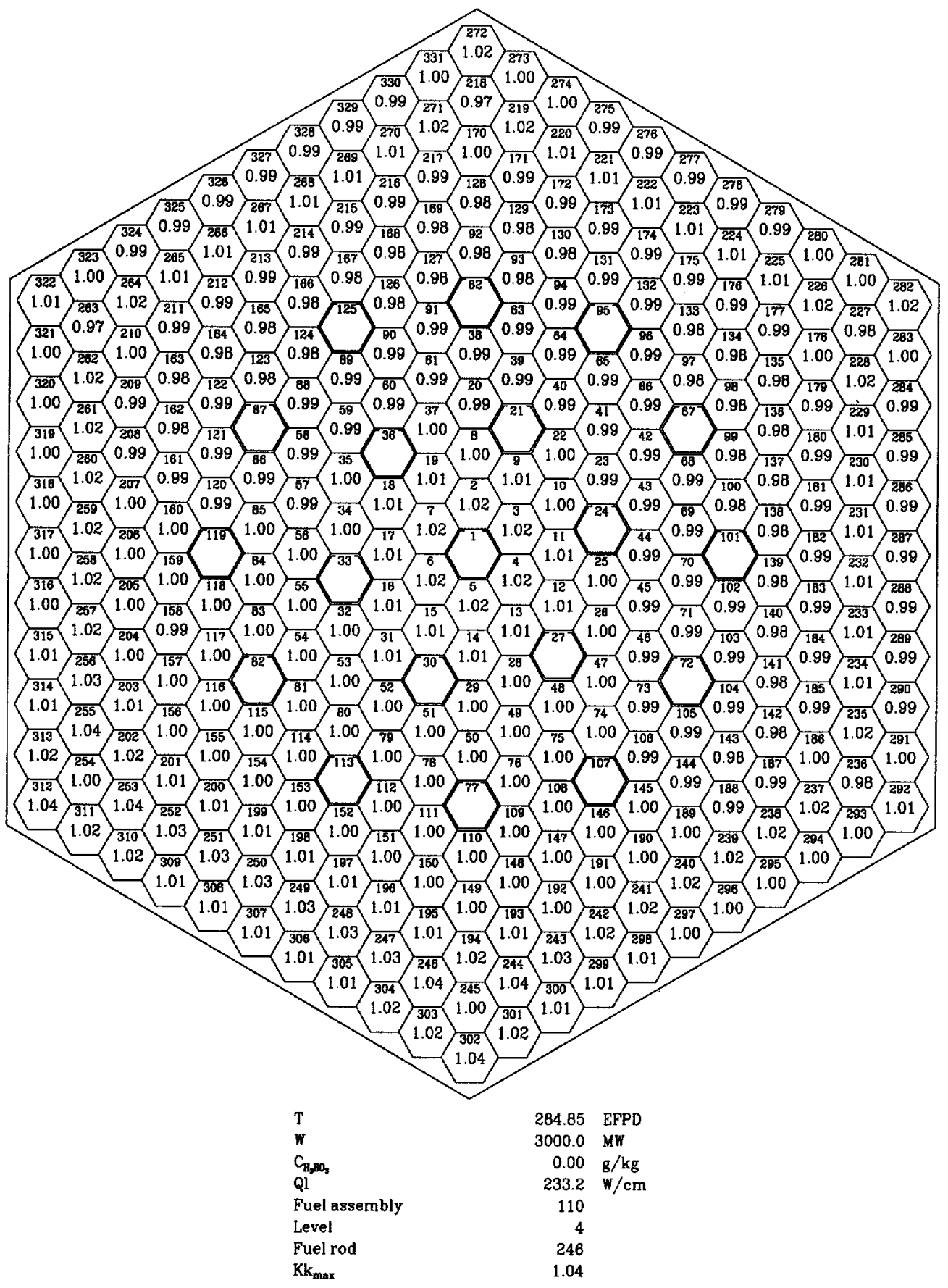


RUSSIAN RESEARCH CENTER KURCHATOV INSTITUTE

Design Studies of "Island" Type MOX Lead Test Assembly (Report for FY99)

Fig.3.25. Pin-by-Pin Power Distribution in MOX LTA in BOC. Second Cycle with 3 MOX LTAs of «lsland-2» Type (Pu3.8-2.8-U3.7)

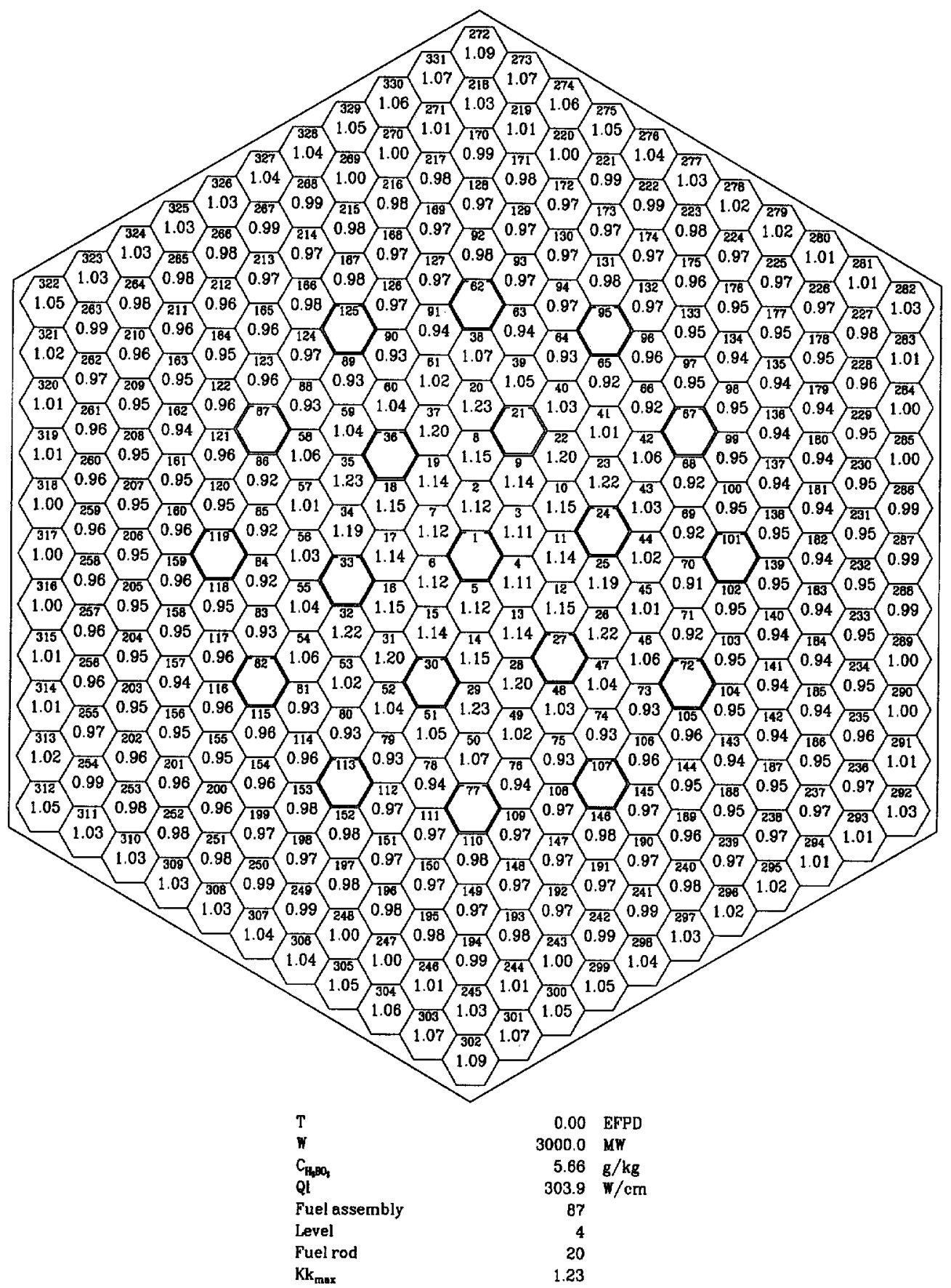


RUSSIAN RESEARCH CENTER KURCHATOV INSTITUTE

Design Studies of "Island" Type MOX Lead Test Assembly (Report for FY99)

Fig.3.26. Pin-by-Pin Power Distribution in MOX LTA in EOC. Second Cycle with 3 MOX LTAs of «lsland-2» Type (Pu3.8-2.8-U3.7)

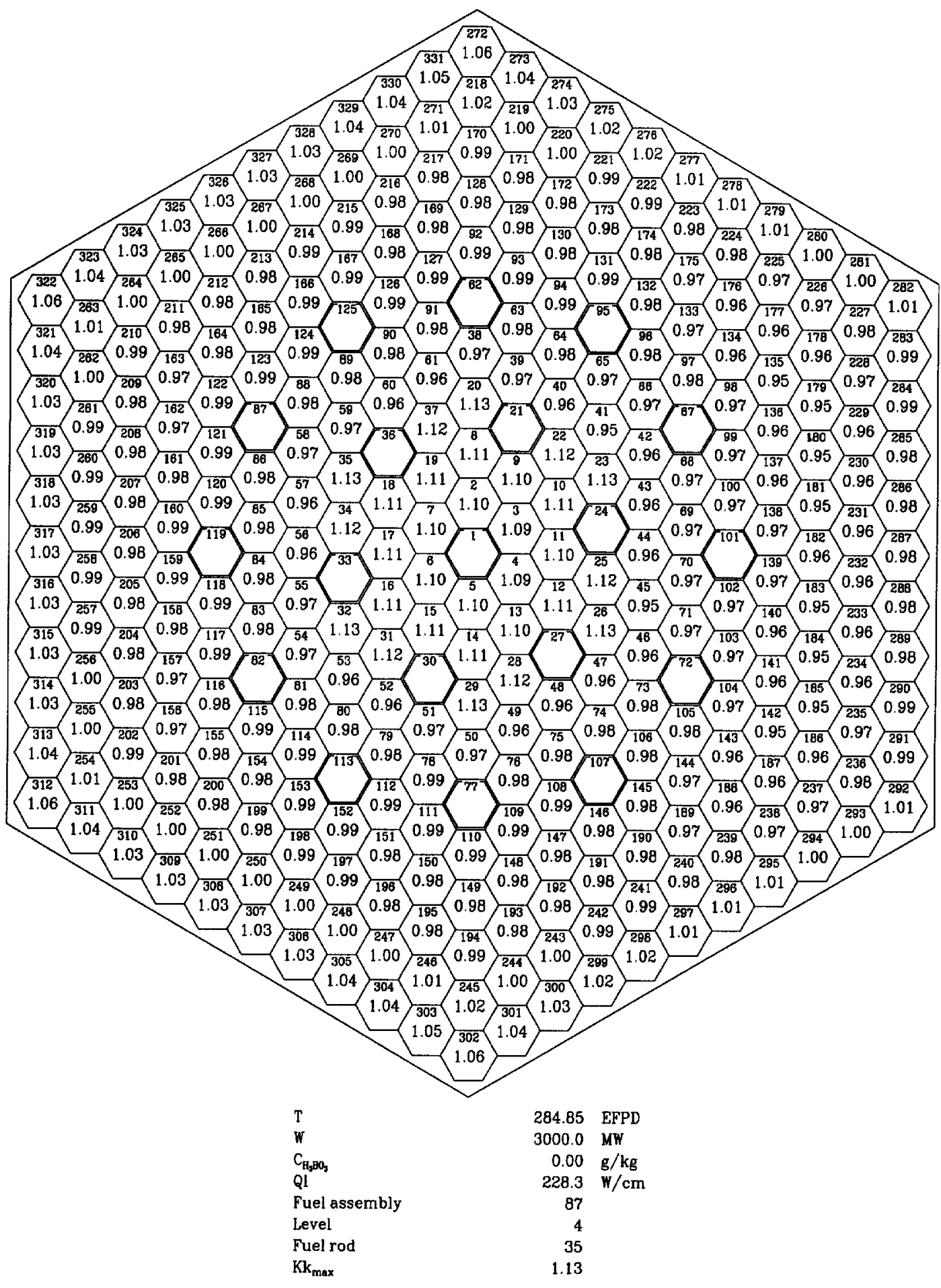


RUSSIAN RESEARCH CENTER KURCHATOV INSTITUTE

Design Studies of "Island" Type MOX Lead Test Assembly (Report for FY99)

Fig.3.27. Reloading scheme.

Third Cycle with 3 MOX LTAs

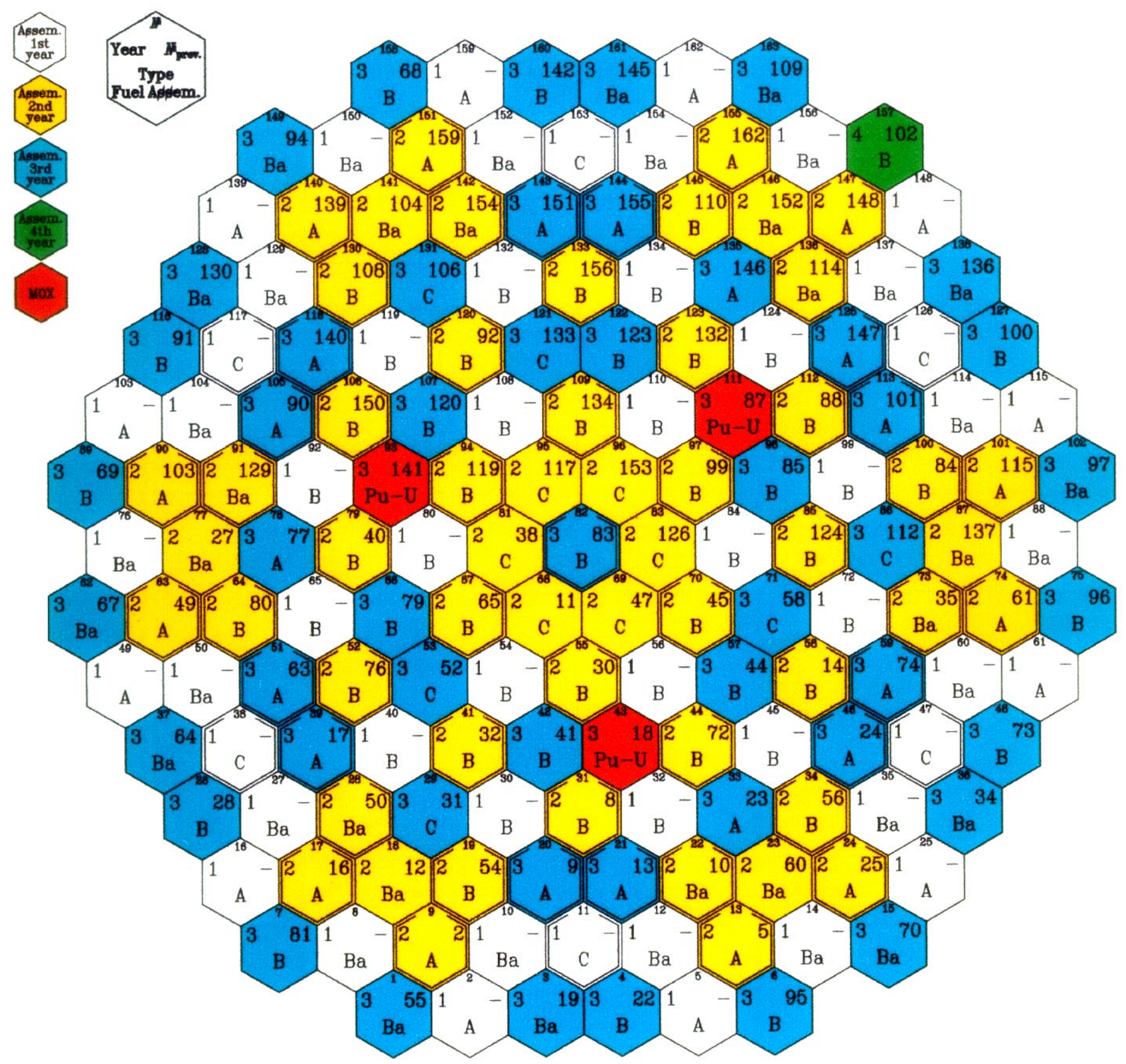


RUSSIAN RESEARCH CENTER KURCHATOV INSTITUTE

Design Studies of "Island" Type MOX Lead Test Assembly (Report for FY99)

Fig.3.28. Assembly-by-Assembly Power Distribution.

Third Cycle with 3 MOX LTAs of "Island-2" Type (Pu3.8-2.8-U3.7)

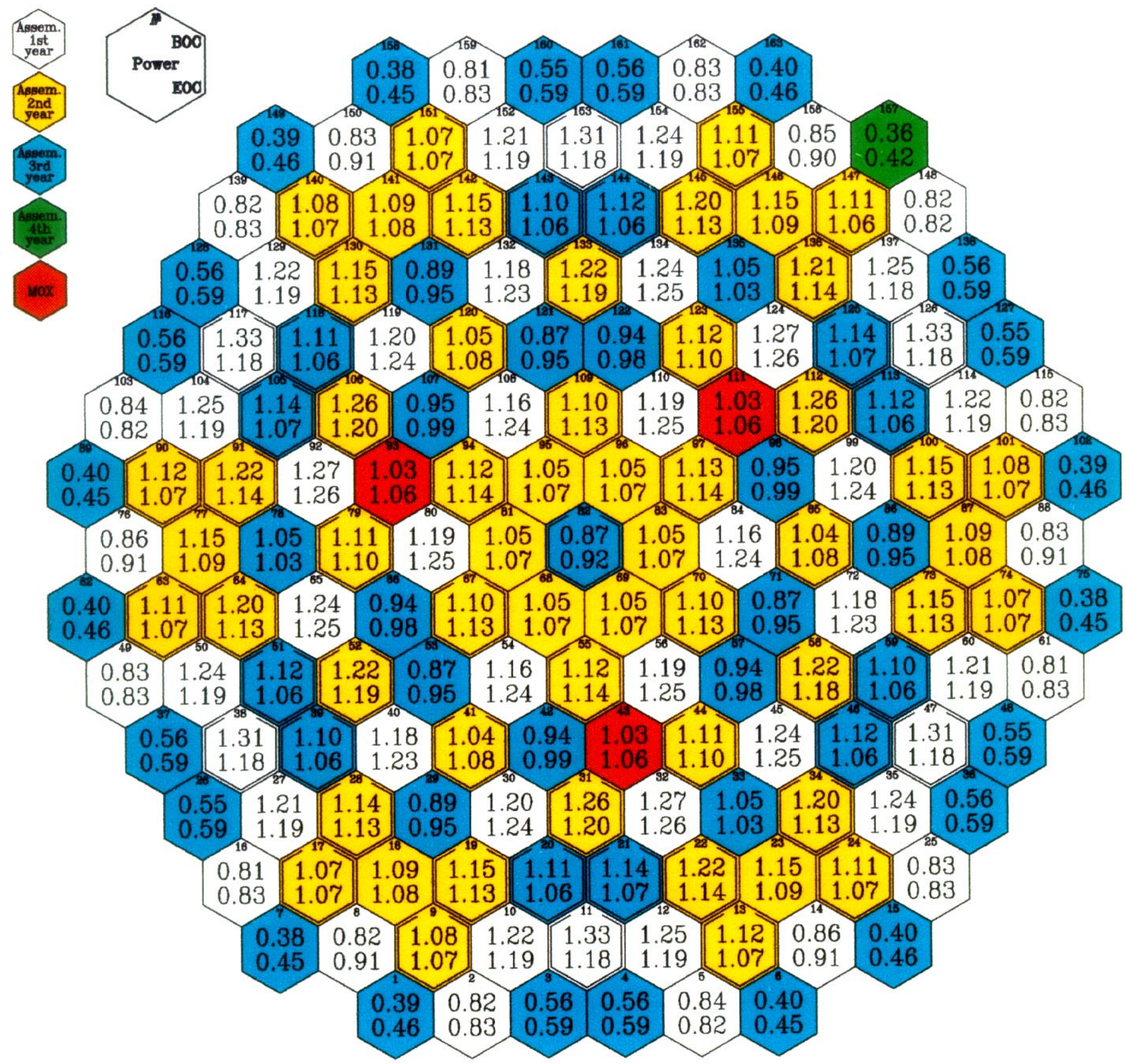


RUSSIAN RESEARCH CENTER KURCHATOV INSTITUTE

Design Studies of "Island" Type MOX Lead Test Assembly (Report for FY99)

Fig.3.29. Assembly-by-Assembly Burnup Distribution.

Third Cycle with 3 MOX LTAs of "Island-2" Type (Pu3.8-2.8-U3.7)

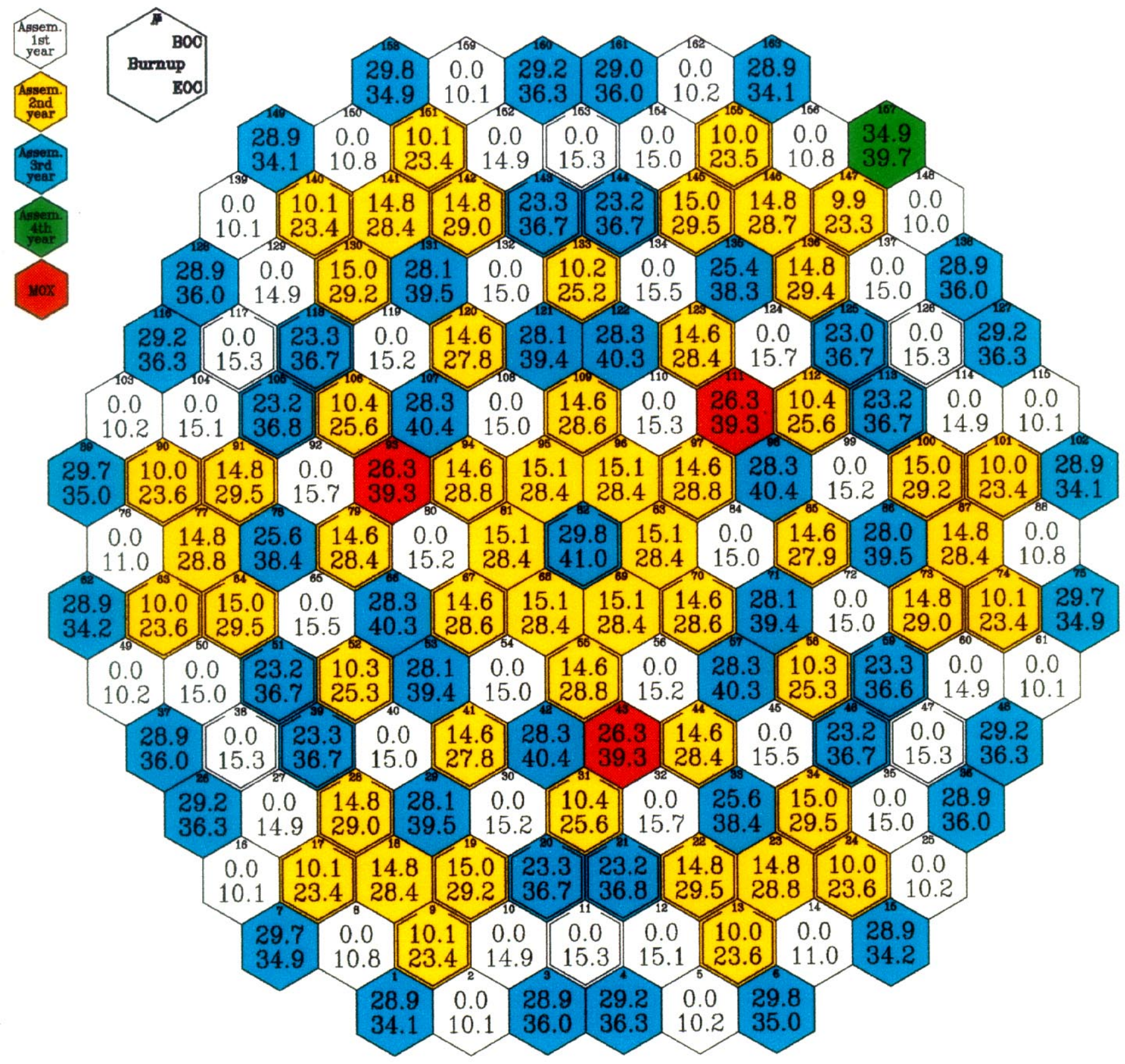


RUSSIAN RESEARCH CENTER KURCHATOV INSTITUTE

Design Studies of "Island" Type MOX Lead Test Assembly (Report for FY99)

Fig.3.30. Assembly-by-Assembly Temperature Drop Distribution.

Third Cycle with 3 MOX LTAs of «/sland-2" Type (Pu3.8-2.8-U3.7)

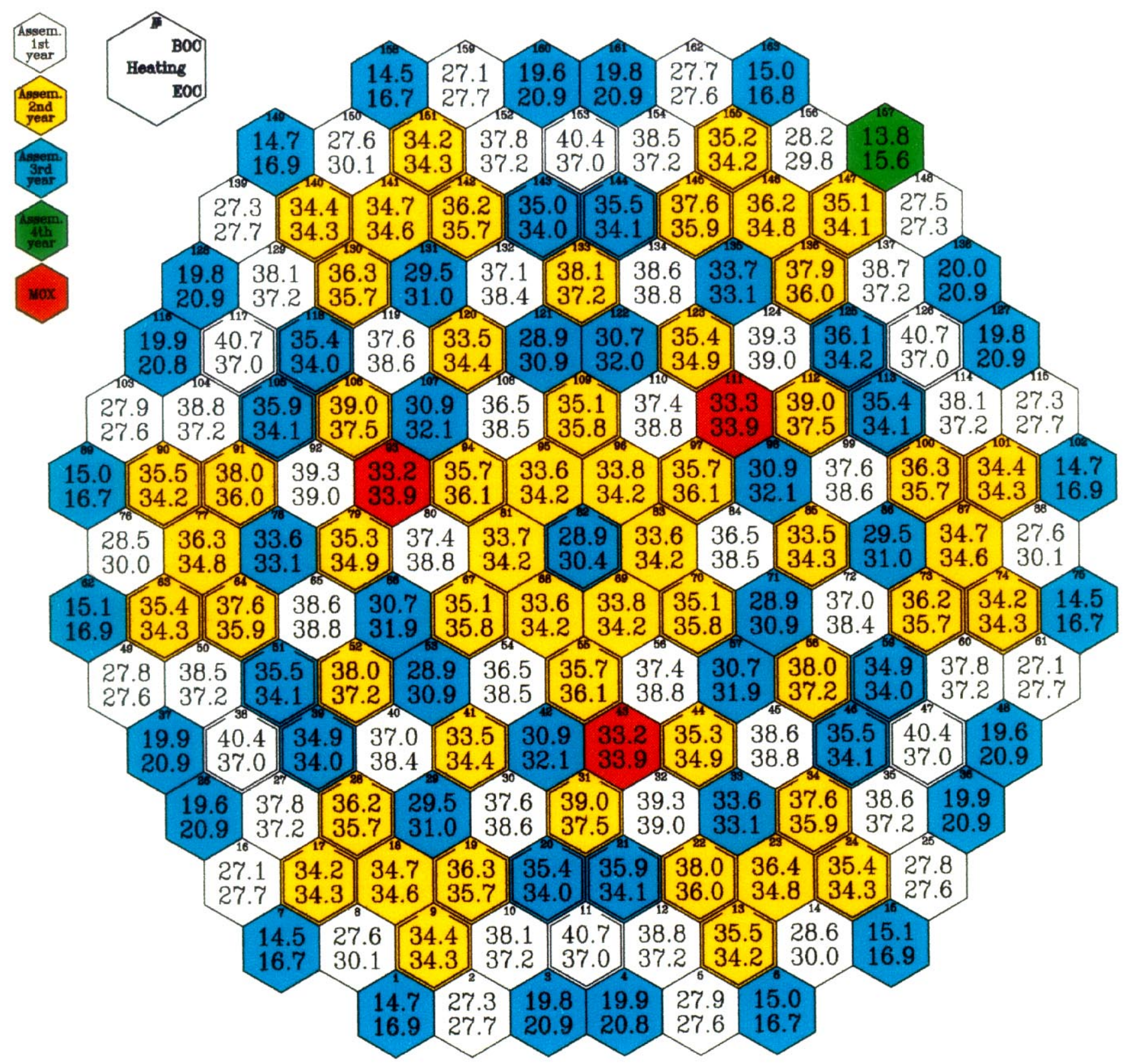


RUSSIAN RESEARCH CENTER KURCHATOV INSTITUTE

Design Studies of "Island" Type MOX Lead Test Assembly (Report for FY99)

Fig.3.31. Assembly-by-Assembly Maximum Linear Power Distribution in BOC. Third Cycle with 3 MOX LTAs of «lsland-2" Type (Pu3.8-2.8-U3.7)

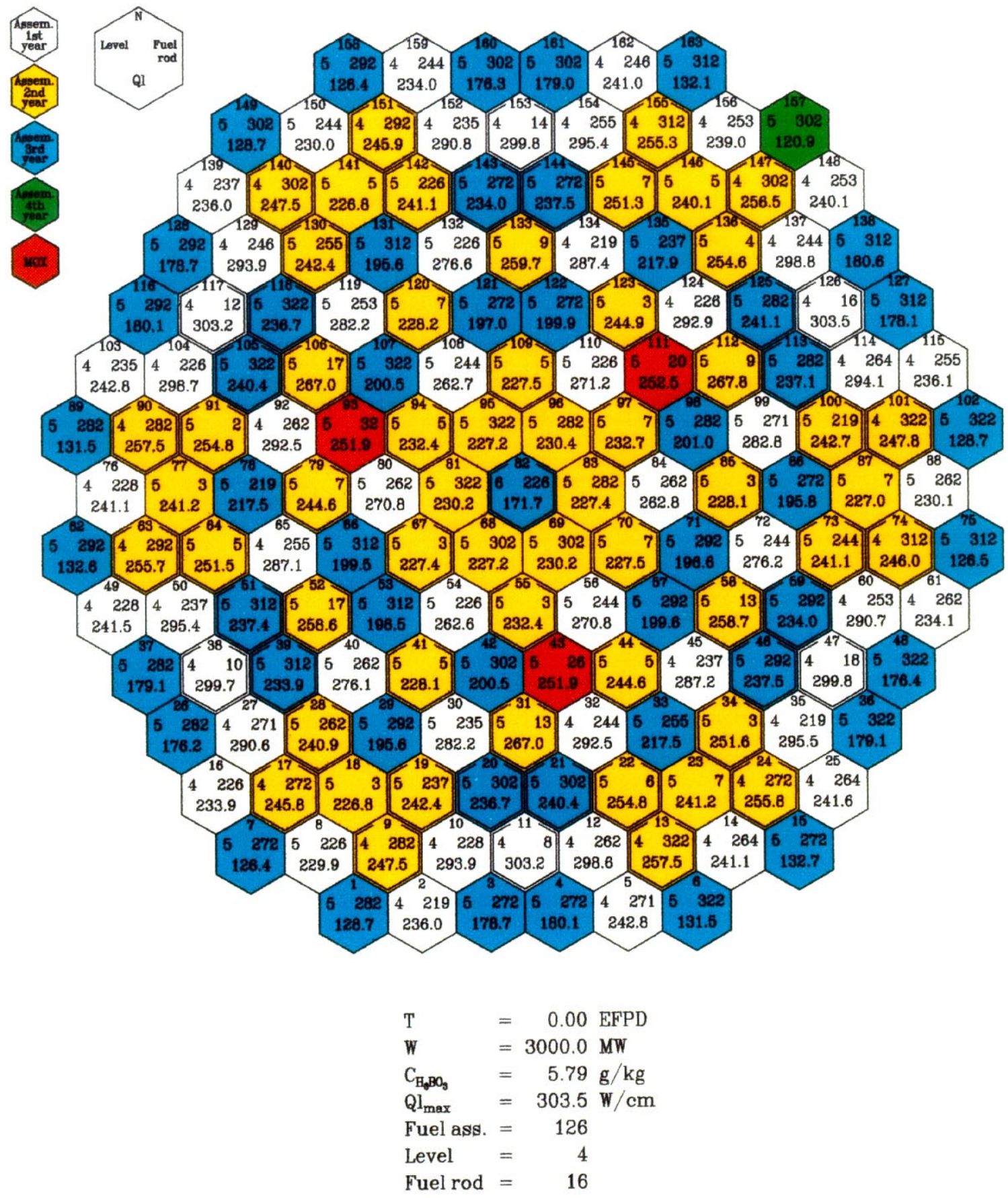


RUSSIAN RESEARCH CENTER KURCHATOV INSTITUTE

Design Studies of "Island" Type MOX Lead Test Assembly (Report for FY99)

Fig.3.32. Assembly-by-Assembly Maximum Linear Power Distribution in EOC.

Third Cycle with 3 MOX LTAs of «Island-2» Type (Pu3.8-2.8-U3.7)

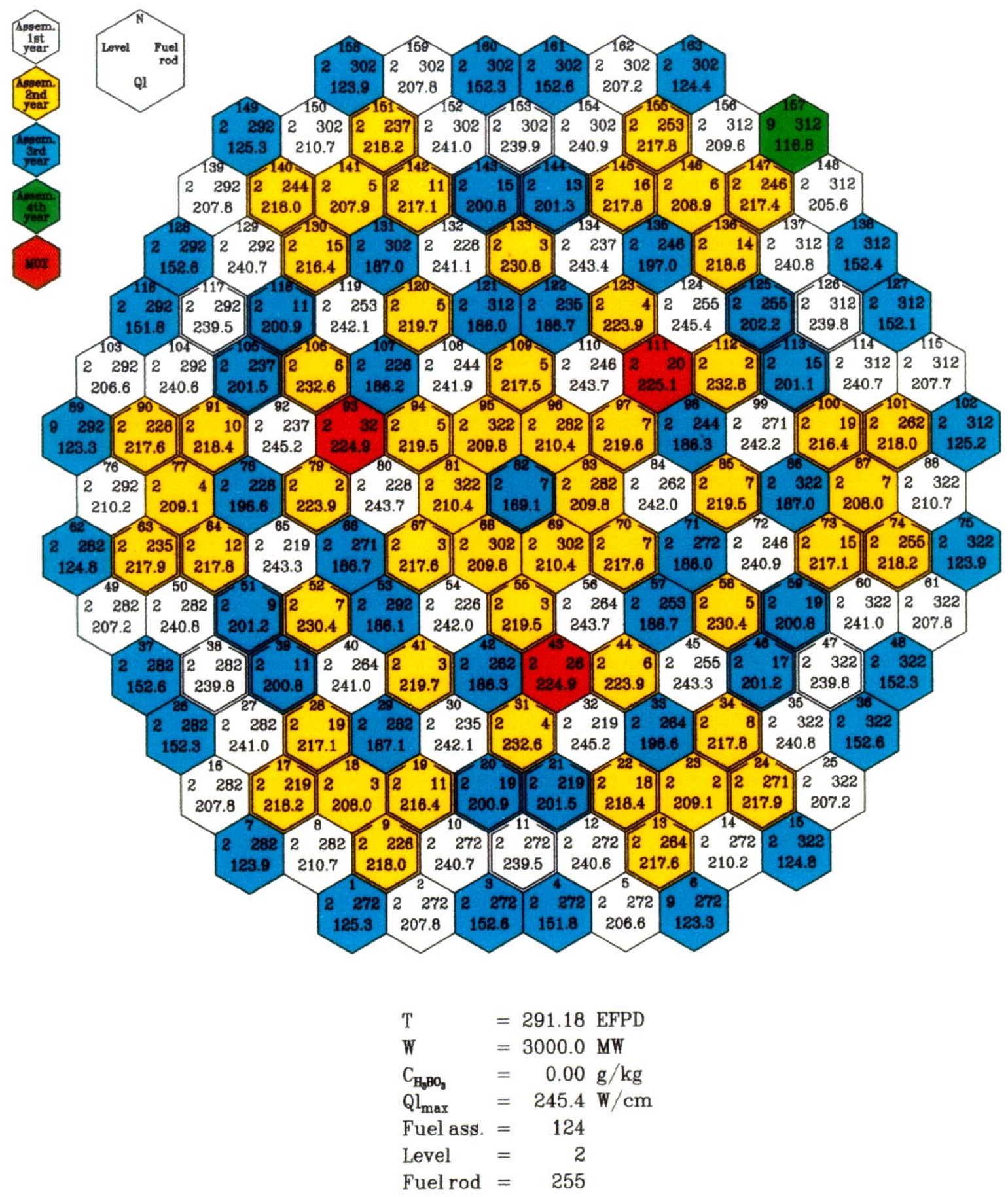


RUSSIAN RESEARCH CENTER KURCHATOV INSTITUTE

Design Studies of "Island" Type MOX Lead Test Assembly (Report for FY99)

Fig.3.33. Pin-by-Pin Power Distribution in the Most Powered Assembly in BOC. Third Cycle with 3 MOX LTAs of «Island-2» Type (Pu3.8-2.8-U3.7)

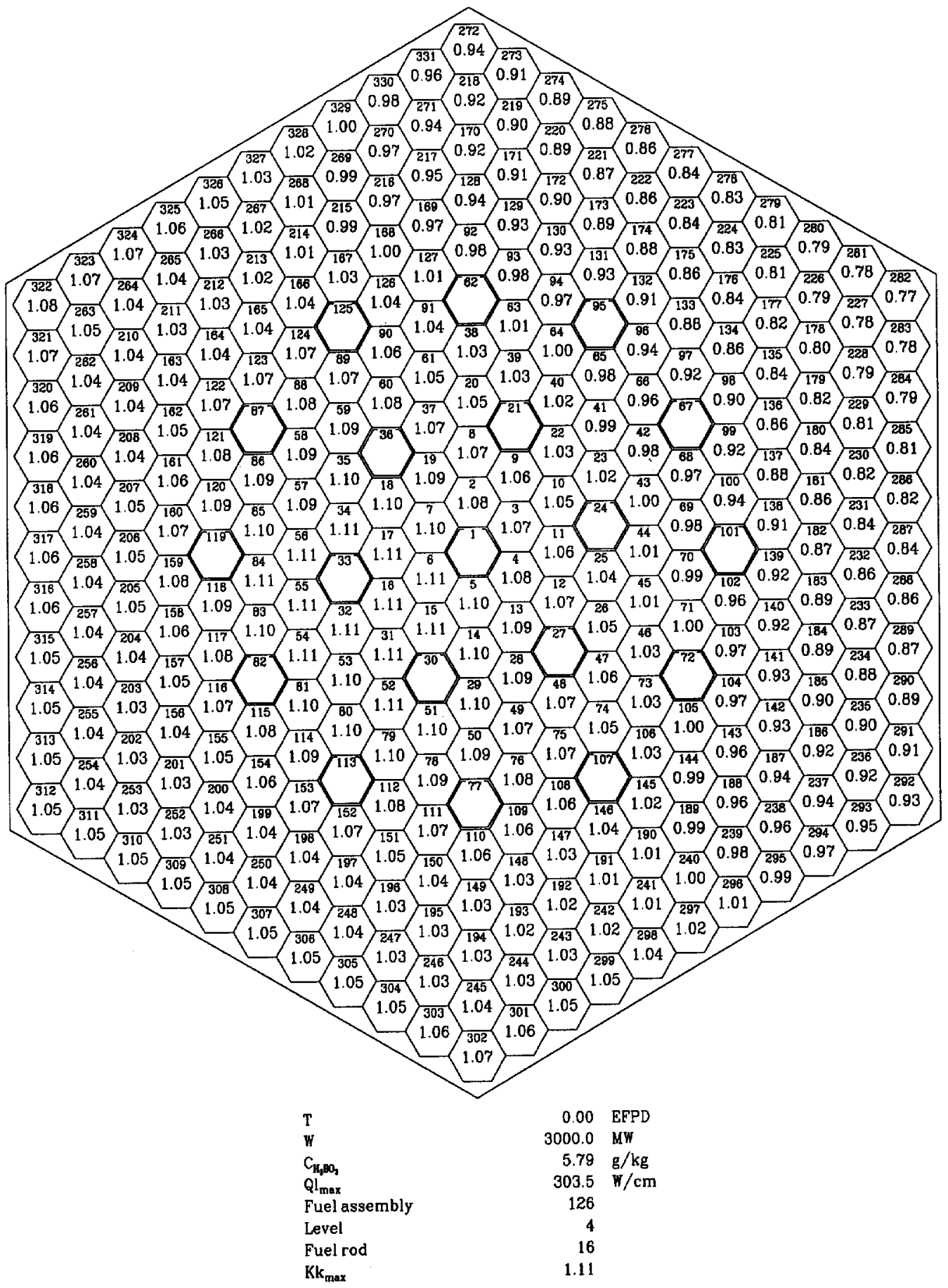


RUSSIAN RESEARCH CENTER KURCHATOV INSTITUTE

Design Studies of "Island" Type MOX Lead Test Assembly (Report for FY99)

Fig.3.34. Pin-by-Pin Power Distribution in the Most Powered Assembly in EOC. Third Cycle with 3 MOX LTAs of "Island-2» Type (Pu3.8-2.8-U3.7)

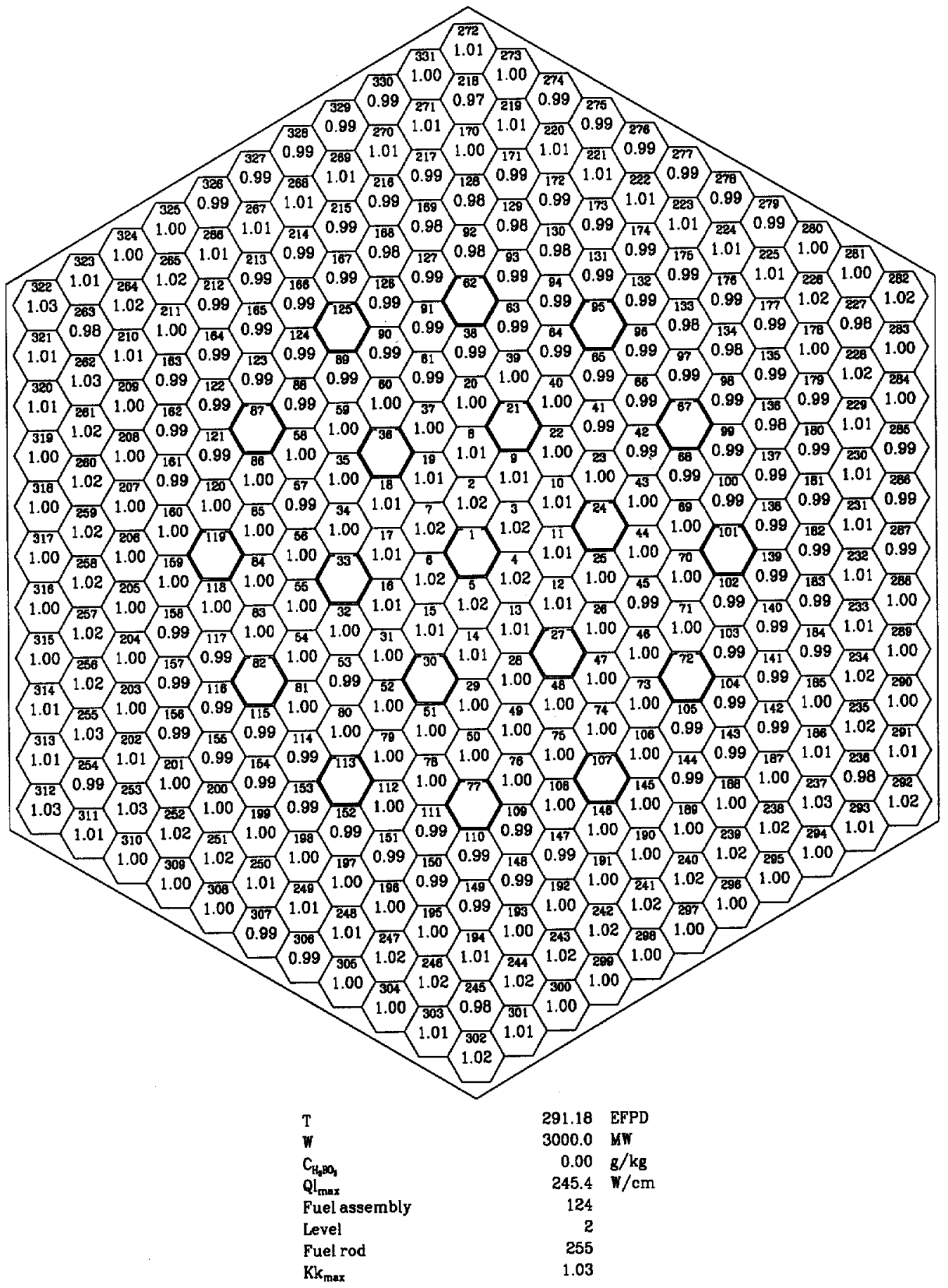


RUSSIAN RESEARCH CENTER KURCHATOV INSTITUTE

Design Studies of "Island" Type MOX Lead Test Assembly (Report for FY99)

\section{Fig.3.35. Pin-by-Pin Power Distribution in MOX LTA in BOC. Third Cycle with 3 MOX LTAs of «Island-2» Type (Pu3.8-2.8-U3.7)}

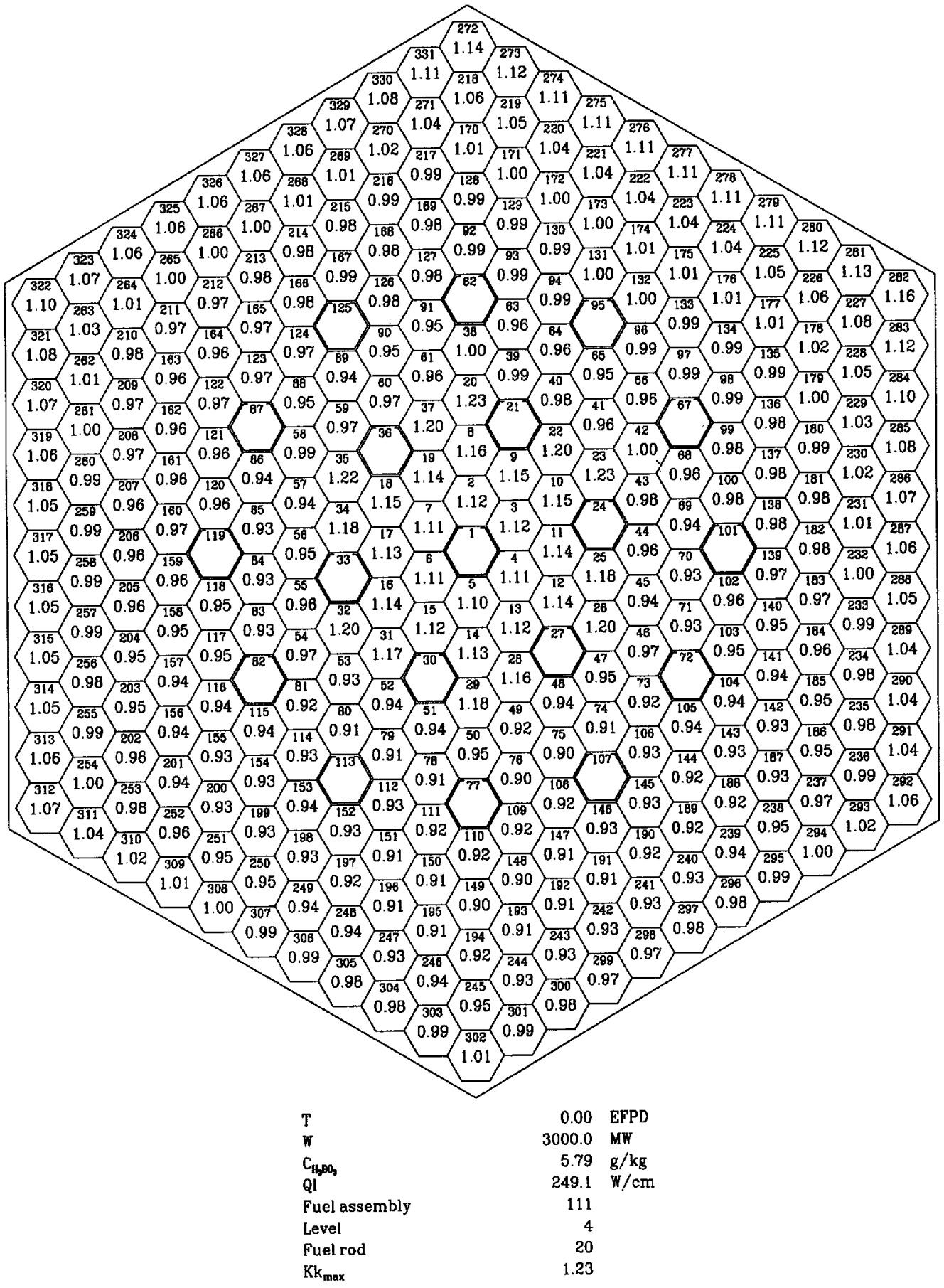


RUSSIAN RESEARCH CENTER KURCHATOV INSTITUTE

Design Studies of "Island" Type MOX Lead Test Assembly (Report for FY99)

Fig.3.36. Pin-by-Pin Power Distribution in MOX LTA in EOC. Third Cycle with 3 MOX LTAs of «lsland-2» Type (Pu3.8-2.8-U3.7)

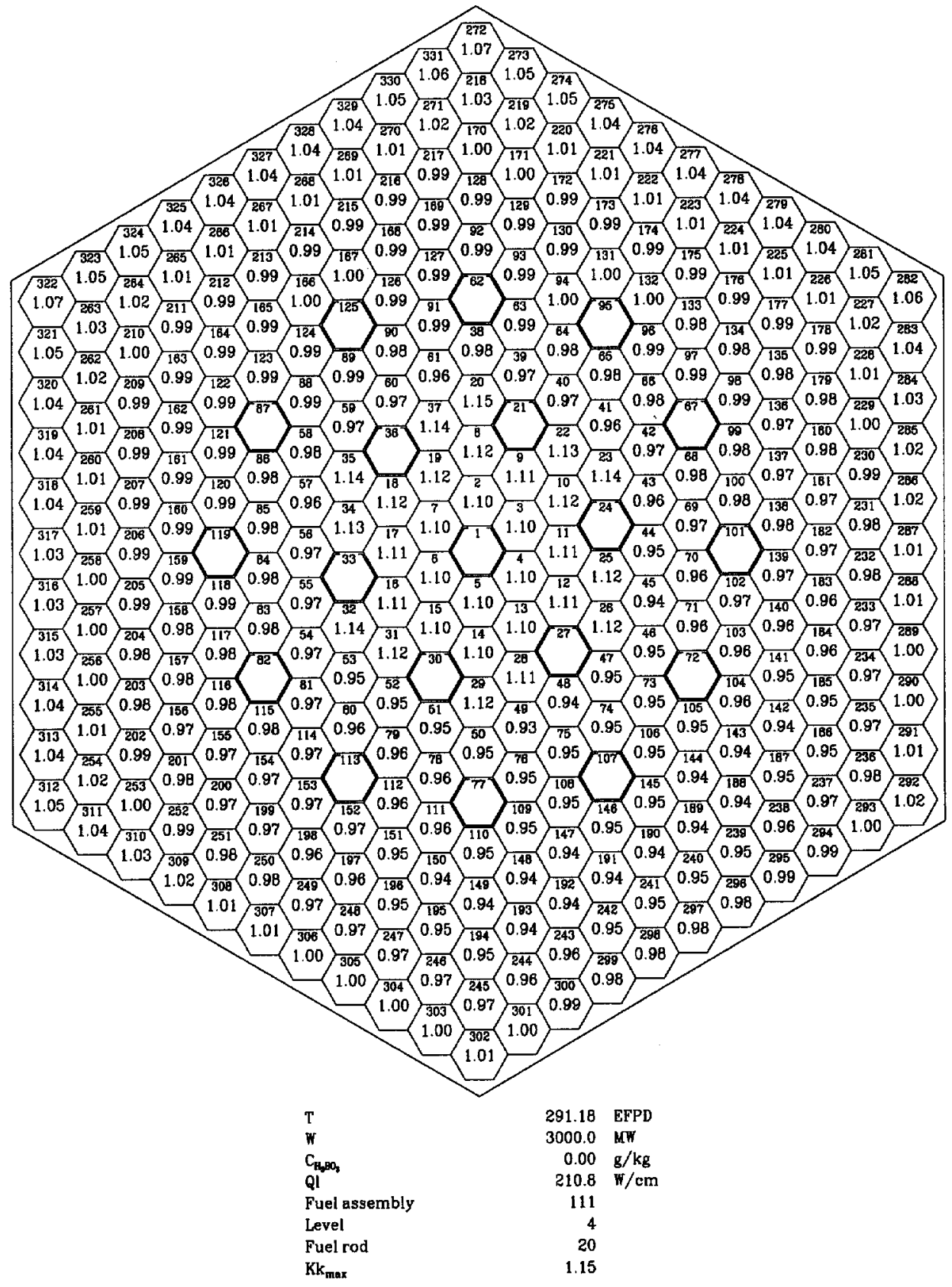


RUSSIAN RESEARCH CENTER KURCHATOV INSTITUTE

Design Studies of "Island" Type MOX Lead Test Assembly (Report for FY99)

\section{ANNEX}




\section{A.1. Cell Code TVS-M}

\section{Nuclear data libraries}

The nuclear data library is based on the same files of estimated nuclear data as precision code MCU-RFFI $\left[1^{*}\right]$, which uses the Monte Carlo method.

In the epithermal energy region $(\mathrm{E}>0.625 \mathrm{eV})$ the calculation is based on slightly modified microcross section library BNAB (see, e.g., [2]) with 24 energy groups. The nuclide libraries can contain both the group and subgroup constants and for some nuclides with temperature dependence.

For the calculation of neutron spectrum in the energy region of resolved resonances $E_{\mathrm{n}}<1 \mathrm{keV}$ (15 and higher $\mathrm{BNAB}$ group) the library includes files of resonance parameters of individual nuclides obtained on the base of the LIPAR library. For all fissile nuclei the library contains prompt and delayed neutron spectra, group $\beta$ values and decay constants for six groups of delayed neutrons.

The thermal energy region is divided into 24 groups. For the nuclides with the " $1 / \mathrm{v}$ " cross-section behavior the absorption cross sections at $2200 \mathrm{~m} / \mathrm{s}$ are used, for the rest ones the group values of the absorption, scattering and fission cross sections are specified. In addition, for oxygen and carbon the scattering matrices obtained in terms of gas model at $300,373,473,558,623 \mathrm{~K}$ are given. For hydrogen bonded in water molecule the scattering matrix is obtained from the ENDF/B recommended data in terms of the Koppel model [3] at the same temperatures.

The library contains the files of cross sections and yields of 98 fission products including ${ }^{135} \mathrm{Xe}$ and ${ }^{149} \mathrm{Sm}$. The files of fission product yields are based on the ENDF/BVI data [4].

\section{Uniform lattice}

In the energy region of epithermal neutrons $\left(10.5 \mathrm{MeV}<\mathrm{E}_{\mathrm{n}}<0.625 \mathrm{eV}, \mathrm{BNAB}\right.$ groups 1-24) a detailed calculation of group spatial-energy distribution of neutron flux is performed. Each group is divided into an arbitrary number of intervals equal in lethargy, and then the calculation is performed at each point of group division. The of elastic scattering process is calculated without use of any approximations when the scattering is isotropic in the inertia center system (i.e.s), otherwise the scattering anisotropy is taken into account by the term not higher than linear in cosine of scattering angle. The slowing down due to inelastic scattering is taken into account via the matrix of inelastic transitions under the assumption of uniform energy distribution of neutrons scattering into the given group.

For nuclides with the subgroup description of cross sections the heterogeneous subgroup calculation of their micro cross sections is performed.

In the energy region of resolved resonances (groups 13-24 BNAB) for resonance nuclides the calculation of all types of cross sections is performed with the use of nuclide

\footnotetext{
${ }^{*}$ References in p.A.1 are placed in the end of A.1
} 


\section{RUSSIAN RESEARCH CENTER KURCHATOV INSTITUTE \\ Design Studies of "Island" Type MOX Lead Test Assembly (Report for FY99)}

resonance parameters. In so doing it is possible to take into account temperature dependence of resonance cross sections.

In the thermal energy region the standard calculation technique is used. It suggests solving the multigroup equation of thermalization with the neutron sources from the epithermal energy region formed when calculation for this energy range was performed.

Calculation of neutron spatial distribution is carried out by dividing the cells into an arbitrary number of annular material zones and by the use of the passing through probability (PTP) method [5]. In the calculation the actual form of the cell boundary is taken into account.

The calculation of the point kinetics parameters $\beta_{\text {eff., }} \ell$ is made by the standard formulas using the value function $\psi$ with respect to $K_{\text {eff }}$ and with six groups of delayed neutrons.

The calculation of the fuel nuclide composition during fuel burnup is performed for heavy nuclides from ${ }^{232} \mathrm{Th}$ to ${ }^{244} \mathrm{Cm}$ and for 98 fission products from ${ }^{82} \mathrm{Kr}$ to ${ }^{163} \mathrm{Dy}$. The burnup equations can be solved both by the Runge-Kutt method and by a faster analytical method described in [6].

\section{Calculation of supercells and fuel assemblies}

For the determination of FA neutronic characteristics the code uses the diffusion fine-mesh calculation with an arbitrary number of groups from 4 to 48 and with the mesh width equal to the pitch between fuel rods in the FA. For the boundary mesh cells the compression coefficient is used. Along with the standard six-point scheme the refined scheme whose principles of construction are described in [7] can be used. The mesh equation has a common form however the quantities in this formula have another sense, namely:

$$
\begin{aligned}
& \frac{4}{3 a^{2}} \sum_{i=1}^{6} \frac{d_{0} d_{i}}{d_{0}+d_{i}}\left(F_{0}-F_{i}\right)+\left(\Lambda_{0}^{a}+\Lambda_{0}^{r}+G_{0}^{Z} B_{z}^{2}\right) F_{0}=S_{0} \\
& F=\varepsilon \Phi \quad \Lambda=\Sigma / \varepsilon \\
& G^{Z}=D^{Z} / \varepsilon \quad d=D^{R} \xi \\
& \varepsilon=\psi(1-\gamma / \delta) \quad \delta=2 d / a
\end{aligned}
$$

In formulas (2-7) $\Phi$ is the cell neutron flux; the sense of quantities $\sum, D^{R}, D^{Z}$ is obvious. Then

$$
\psi=\frac{\Phi_{b}^{s}}{\bar{\Phi}^{s}} \quad \xi=\frac{j_{b}^{a}}{\bar{j}^{a}}
$$

Here $\Phi$ is the neutron flux in the given mesh cell; $j$ is the neutron current in the cell; index " $b$ " means the value of corresponding quantity at the cell boundary; index " $s$ " indicates the solution of transport equation in the cell with symmetric boundary conditions (symmetric inflowing and outflowing neutron current); index " $a$ " is the solution with asymmetric boundary conditions (neutron current flowing through the cell); the bar shows the quantity value averaged over the cell.

The use of these quantities permits joining of accurate (i.e. obtained from solving of transport equation for the cell) neutron flux and current at the cell boundary and 


\section{RUSSIAN RESEARCH CENTER KURCHATOV INSTITUTE \\ Design Studies of "Island" Type MOX Lead Test Assembly (Report for FY99)}

keeping of the accurate connection between the solution of equation (1) and the reaction rates in the cell. In this way it becomes possible to avoid errors peculiar to the standard calculation scheme associated with the finite size and heterogeneous structure of mesh points. For solving the set of equations any modules of diffusion equation solutions can be used.

As usual the process of solving the diffusion equations is divided into the solving of the equation for each group and the determination of fission source by means of external iterations. If the state of FA at power is considered then upon their completion the external iterations are added with the calculation of ${ }^{135} \mathrm{Xe}$ and ${ }^{149} \mathrm{Sm}$ concentrations and a new iteration cycle.

Each mesh point pertains to a definite type: fuel rod, cell with absorber rod, cell corresponding the gap between FAs, etc. The constants for the background type are always calculated in the asymptotic mode, i.e. as for the uniform fuel cell. The constants for non-fuel cells are calculated in the mode of supercell. For the non-background fuel cells including those with integrated burnable poison (named tvegs) the calculation can be performed both in the asymptotic and supercell modes. The homogenized background cell is always considered as the external zone of supercell.

\section{References}

1. Gomin E.A., Majorov L.V. The MCU-RFFI Monte Carlo Code for Reactor Design Applications. Proc. of Int. Conf. on Math. and Comp., Reac. Phys. and Envir. Analyses, April 30 -4 May 1995, Portlend, Oregon, USA

2. L.P.Abagyan et al. Group constants for calculation of the reactors and shields. M., Energoizdat, 1981.

3. Koppel J.U., Houston S.H. Reference for ENDF Thermal Neutron Scattering Data, GA-8774, 1978

4. ENDF-102. Data Formats and Procedures for the Evaluated Nuclear Data Files ENDF-6, July 1990, National Nuclear Data Center, Brookhaven National Laboratory, Upton, NewYork, 11973

5. I.E.Rubin. Method of probabilities of transmission in the one-dimensional cylindrical geometry. Izvestiya AN BSSR, ser. fiz-energ. nauk, № 2, p. 25-31, 1983.

6. V.M.Kolobashkin et al. Radiation characteristics of irradiated nuclear fuel M., Energoatomizdat, 1983.

7. V.D.Sidorenko. Homogenization of effective cross sections in the periodic lattice. Preprint IAE-2793, 1977. 
RUSSIAN RESEARCH CENTER KURCHATOV INSTITUTE

Design Studies of "Island" Type MOX Lead Test Assembly (Report for FY99)

\section{A.2. Coarse-Mesh Code BIPR-7A}

BIPR-7A is a 3-dimensional hexagonal coarse-mesh code intended to calculate neutronics characteristics of VVER-type reactor core.

Calculational cell represents assembly transversal section in horizontal plane and usually one-tenth of core height in axial direction i.e. there are 1630 cells in VVER-1000 core. Neutronics parameters are homogeneous within a cell.

Radial, upper and lower reflectors are described by border conditions.

Calculation is performed in two energetic groups using the so-called modal presentation of group fluxes [8].

Cell constants, prepared by the code TBC-M [4], form a library and represent a number of polynomials that reflect the two-group neutronics cross sections dependence on moderator density, moderator temperature, fuel temperature, FP concentrations in fuel, boron acid concentration in coolant, Xe and Sm concentration in fuel.

BIPR-7A is a part of industrial super-code KASKAD that allows obtaining in convenient formats all the parameters necessary for reactor safety estimations and licensing.

As a result BIPR-7A calculate the following parameters:

$$
\begin{array}{ll}
\text { - } & \mathrm{q}_{\mathrm{i},} \\
\text { - } & \mathrm{Kq}, \\
\text { - } & \mathrm{q} \mathrm{ij}, \\
\text { - } & \mathrm{BU}, \\
\text { - } & \mathrm{BUij}, \\
\text { - } & \mathrm{MTC}, \\
\text { - } & \mathrm{MDC}, \\
\text { - } & \mathrm{DRC}, \\
\text { - } & \quad \mathrm{Beff}, \\
\text { - } & \lambda \mathrm{Cb}, \\
\text { - } & \mathrm{RO} \mathrm{B}_{\mathrm{CRT}}, \\
\text { - } & (\mathrm{RO})_{\mathrm{AP}}, \\
\end{array}
$$




\section{A.3. Fine-Mesh Code PERMAK-A}

PERMAK-A is a 2-dimensional fine-mesh code intended to calculate neutronics characteristics of VVER-type reactor core.

Calculational cell represents fuel pin-type hexagonal cell with homogeneous neutronics parameters within it.

Diffusion finite-differencies neutron balance equation in few energetic groups are resolved.

Radial reflector is described by the same manner as a core.

Neutron flux axial gradients, obtained by BIPR-7A, are used while calculating one (as usual) the most powered core axial level.

Cell (fuel and non-fuel) constants, prepared by the code TBC-M [4], form a special library and represent a number of polynomials that reflect the group neutronics cross sections dependence on moderator density, moderator temperature, fuel temperature, FP concentrations in fuel, boron acid concentration in coolant, Xe and Sm concentration in fuel.

PERMAK-A is a part of industrial super-code KASKAD that allows obtaining in convenient formats all the parameters necessary for reactor safety estimations and licensing.

As a result PERMAK-A calculates the following parameters:

- $\mathrm{q}_{\mathrm{k}}$,

- $\mathrm{Kk}$,

- $\mathrm{Kr}$;

- BUk,

- $\mathrm{Q}_{1}$

- $\mathrm{K}_{\text {o-total. }}$ 
RUSSIAN RESEARCH CENTER KURCHATOV INSTITUTE

Design Studies of "Island" Type MOX Lead Test Assembly (Report for FY99)

\section{A.4. Reflector Description}

The simplified structure of VVER-1000 radial reflector is presented in Fig. A.2.. In KI fine-mesh calculations by the code PERMAK-A the radial VVER-1000 reflector is modeled by "reflector assemblies" of five types (Figures A.1, A.3-A.7). Zero flux is applied on the outer reflector borders. The corresponding geometric condensation factors are applied to the cell types of reflector if the cells are situated in "reflector assembly" corners or on the borders.

The upper and lower reflectors can be described on the base of reactor core design presented in [1]. 


\section{Figure A.1. Equilibrium Loading Pattern for Base Uranium Core with Boron}

BPRs, Core $60^{\circ}$ Sector

Enrichment graded by 3,3\% Replaced After 3 Years (No BPRs)

Bn - 3,7\% Enrichment graded by 3,3\% Replaced After 3/4 Years $(0,065 \mathrm{~g} / \mathrm{cc}$ Boron BPRs, removed after 1 st year $)$

Cn - 3,3\% Enrichment Replaced After 3 Years (No BPRs)

1-28 - Positions in 60 Degree Sector n - Current Cycle of Fuel Assembly Symbol e.g. \$ - Position of a Fuel Assembly During Lifetime in Core

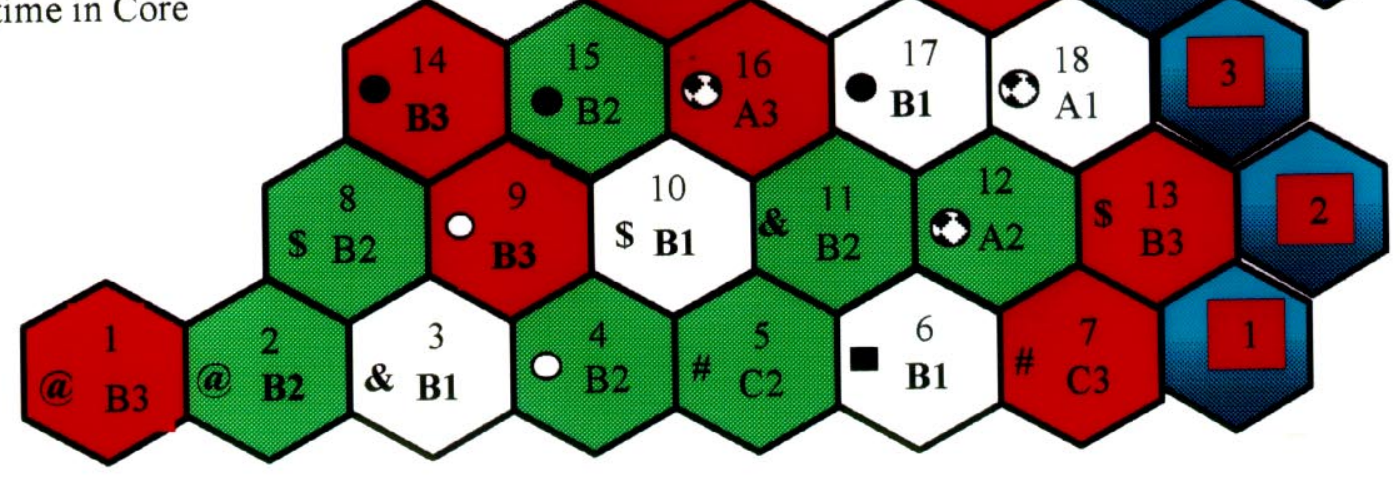

1st year assembly

2nd year assembly

3 d year assembly

4th year assembly

Reflector 
Figure A.2. Model of VVER-1000 Radial Reflector

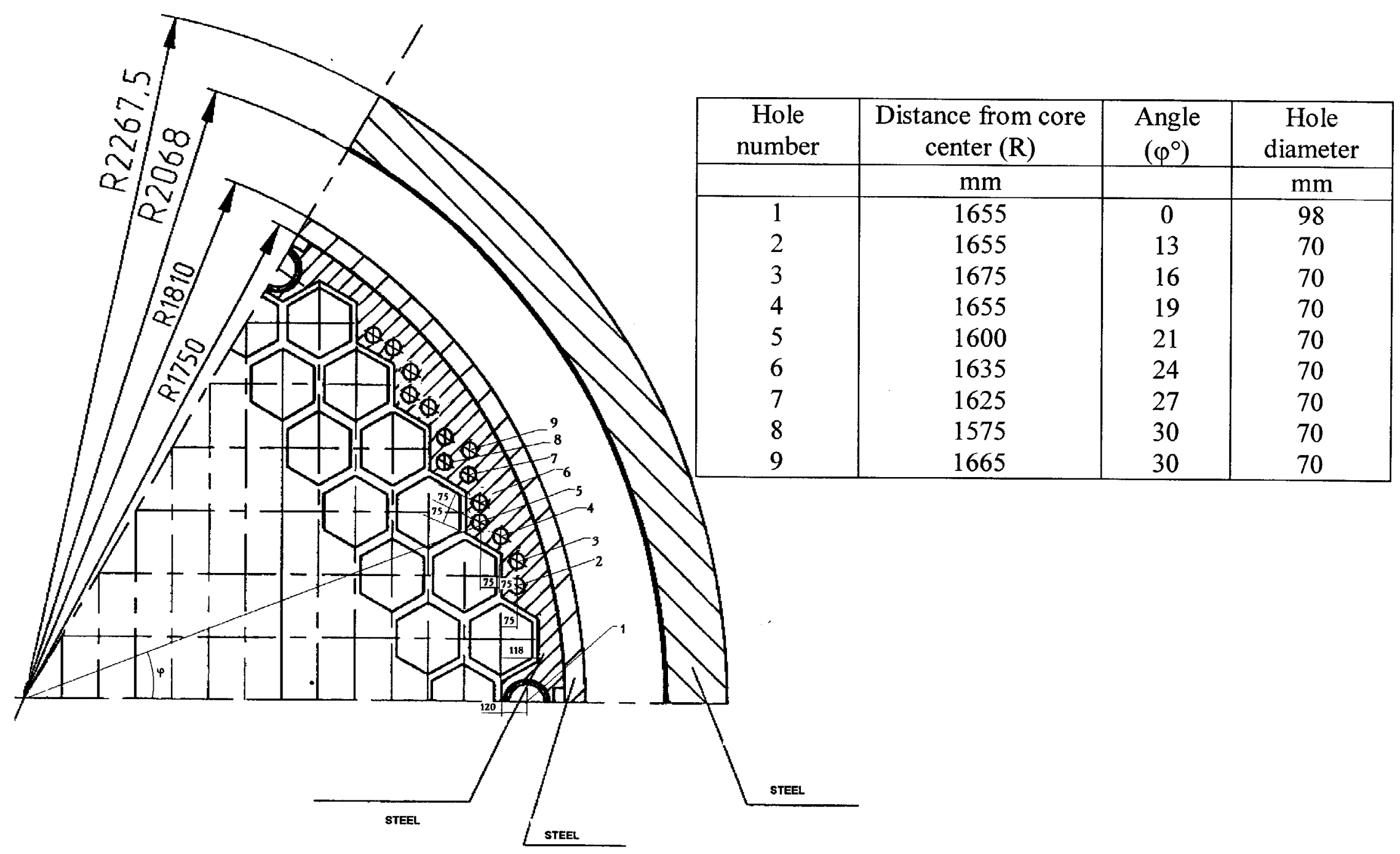

RRC KI. Design Studies of "Island" Type MOX Lead Test Assembly (Report for FY99) 
RUSSIAN RESEARCH CENTER KURCHATOV INSTITUTE

Design Studies of "Island" Type MOX Lead Test Assembly (Report for FY99)

Fig.A.3. Reflector "assembly" of type 1

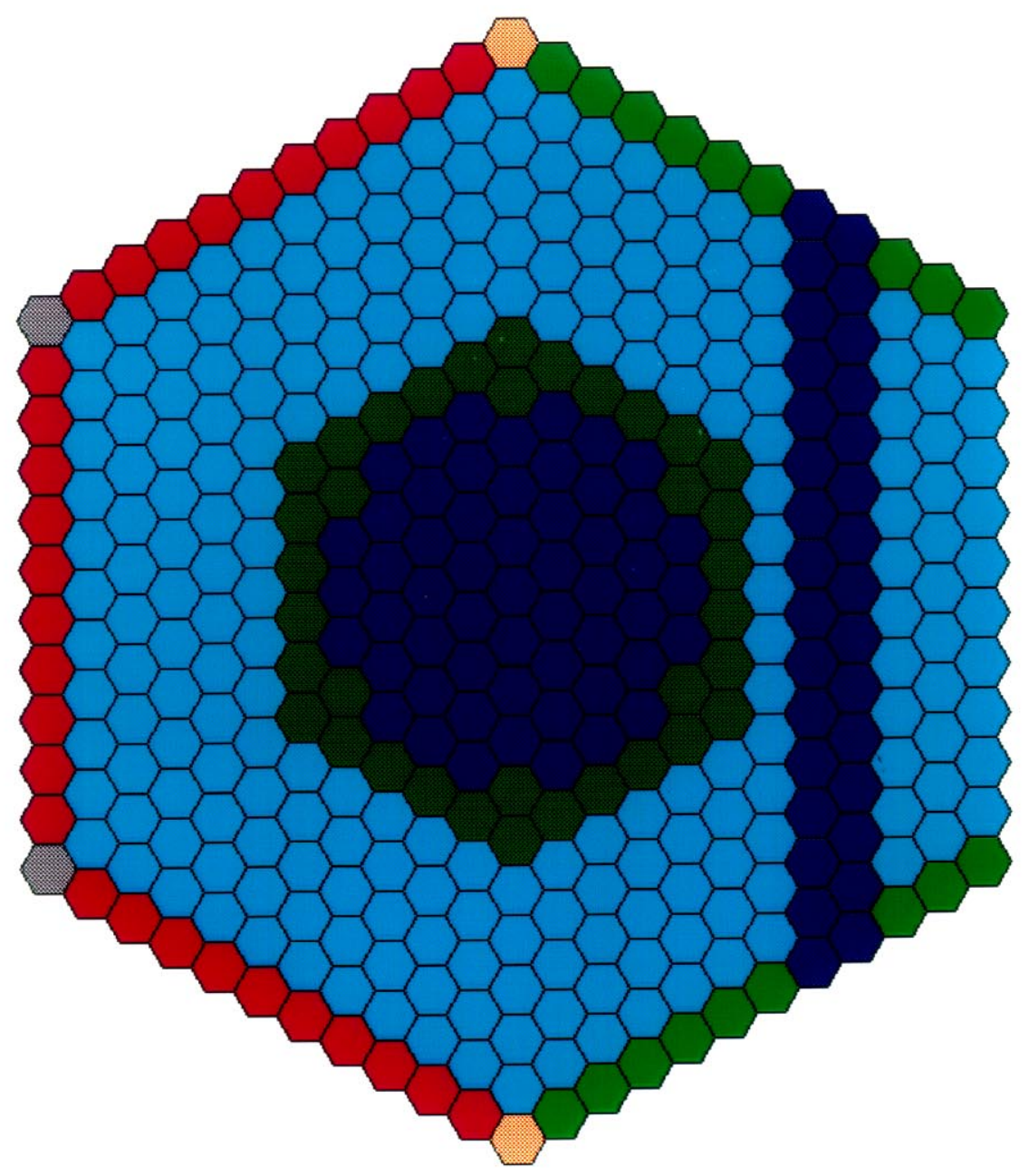

Steel 100 Water 0

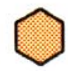

Steel 50 Water 50

Steel 0 Water 100

Steel 50 Water 50

Steel 11 Water 89

Steel 26 Water 74

Steel 100 Water 0

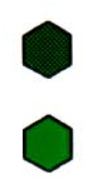


RUSSIAN RESEARCH CENTER KURCHATOV INSTITUTE

Design Studies of "Island" Type MOX Lead Test Assembly (Report for FY99)

Fig.A.4. Reflector "assembly" of type 2

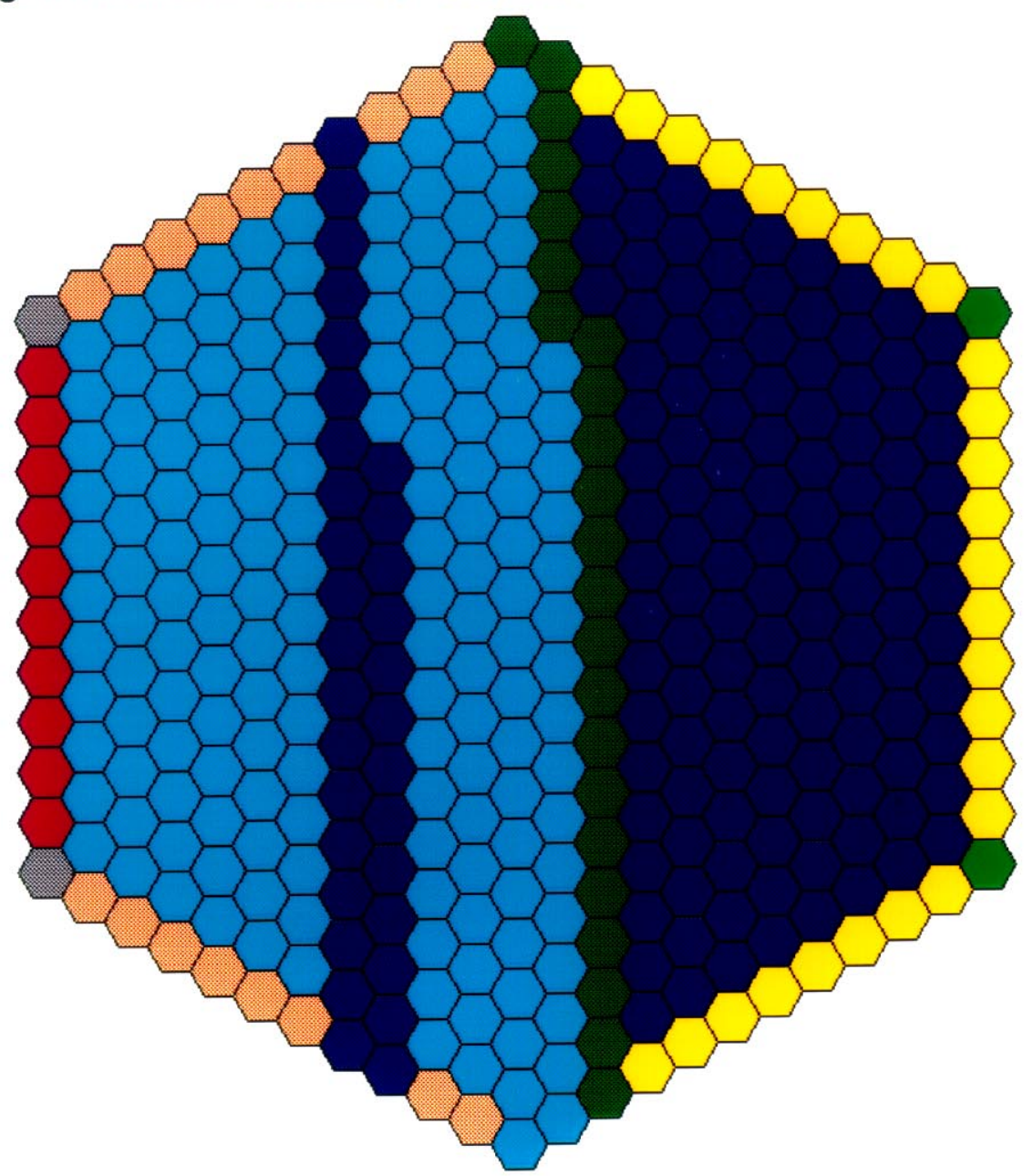

Steel 100 Water 0
Steel 0 Water 100
Steel 26 Water 74
Corner (Water 100)

Steel 50 Water 50
Steel 75 Water 25
Steel 100 Water 0
Plane (Water 100)


RUSSIAN RESEARCH CENTER KURCHATOV INSTITUTE

Design Studies of "Island" Type MOX Lead Test Assembly (Report for FY99)

\section{Fig.A.5. Reflector "assembly" of type 3}

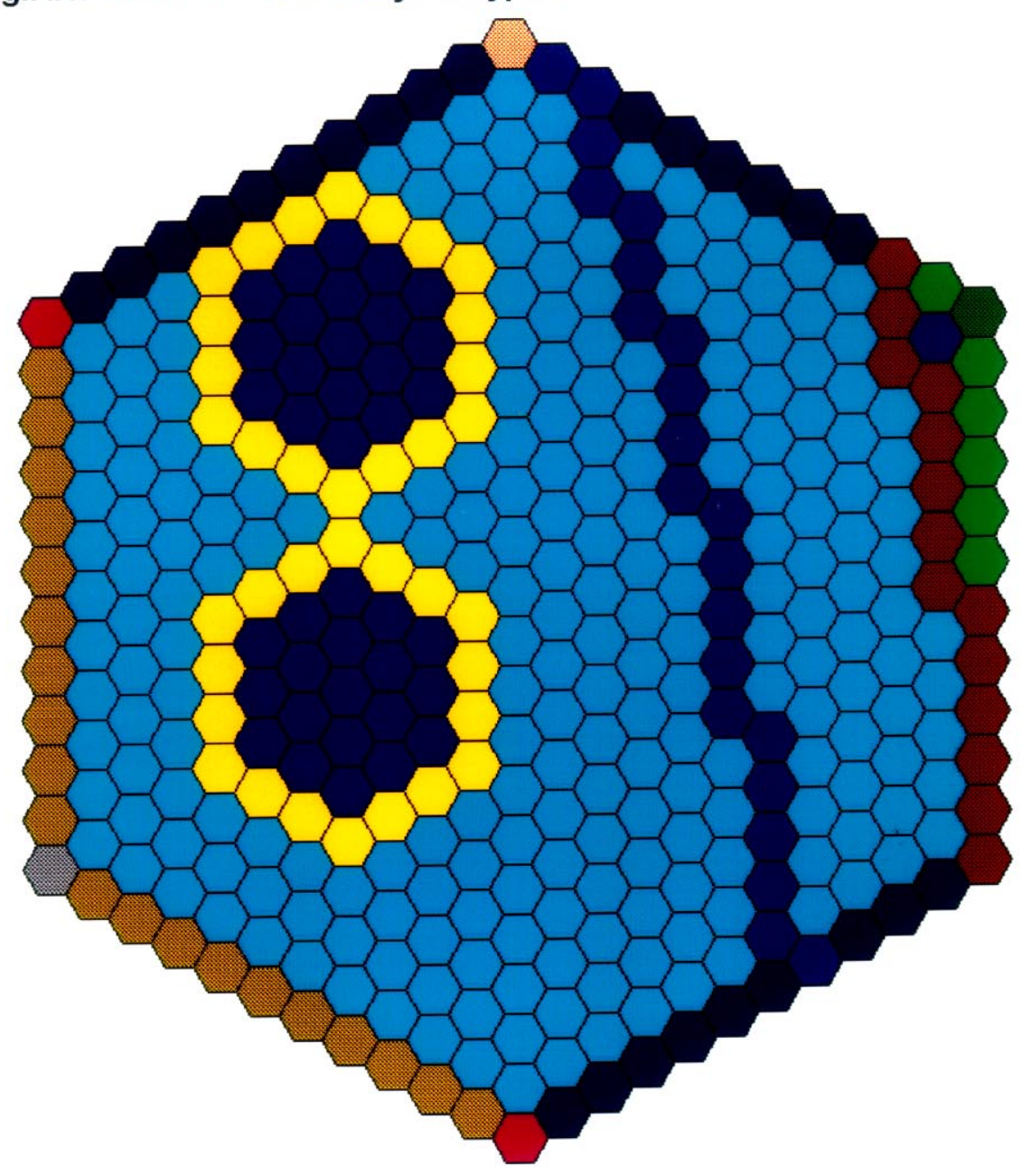

Steel 100 Water 0
Steel 0 Water 100
Steel 50 Water 50
Plane (Water 100)
Steel 75 Water 25

Steel $100 \mathrm{Water} 0$ 
RUSSIAN RESEARCH CENTER KURCHATOV INSTITUTE

Design Studies of "Island" Type MOX Lead Test Assembly (Report for FY99)

Fig.A.6. Reflector "assembly" of type 4

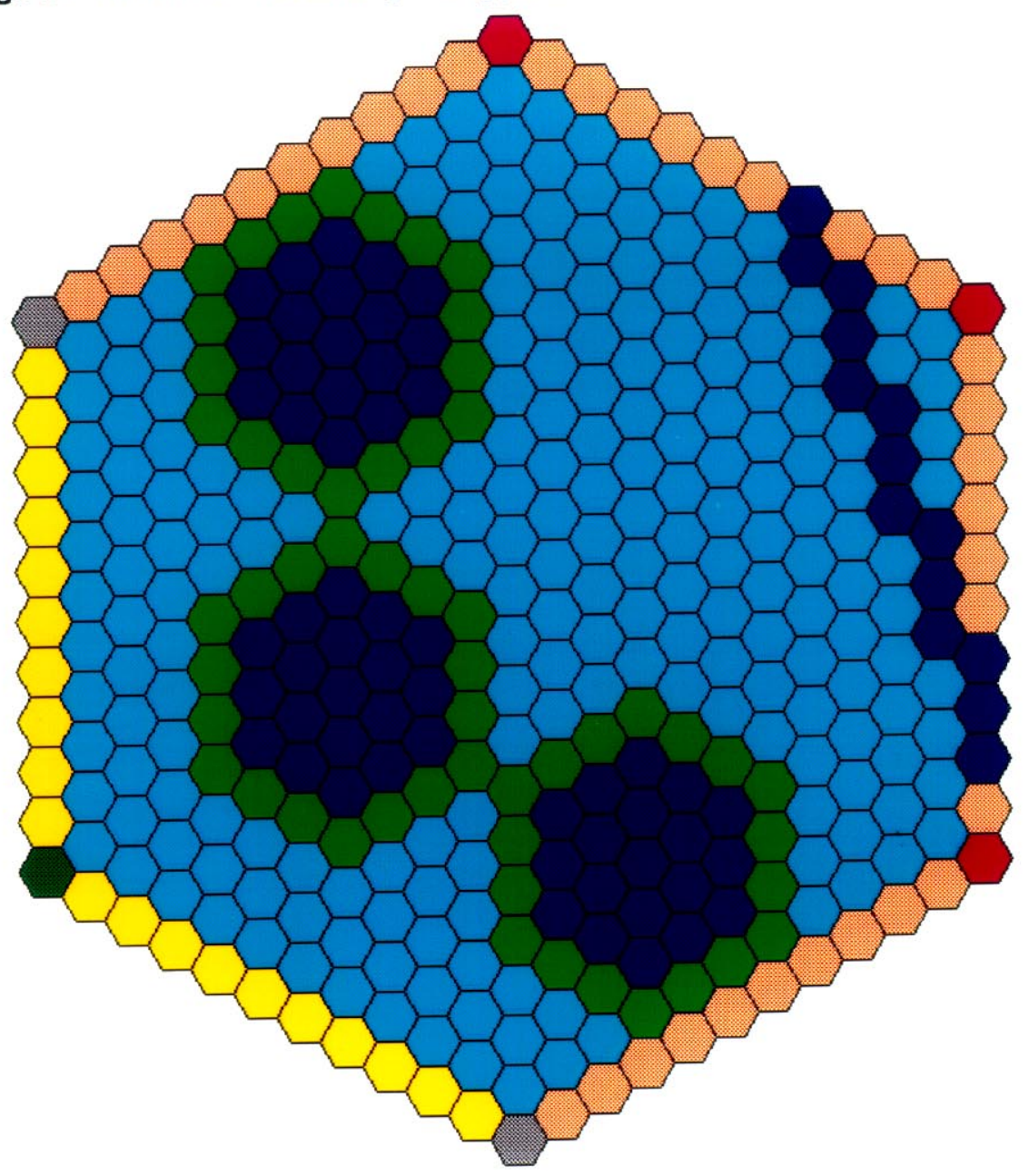

Steel 100 Water 0
Steel 0 Water 100
Steel 100
Steel 50 Water 50


RUSSIAN RESEARCH CENTER KURCHATOV INSTITUTE

Design Studies of "Island" Type MOX Lead Test Assembly (Report for FY99)

Fig.A.7. Reflector "assembly" of type 5

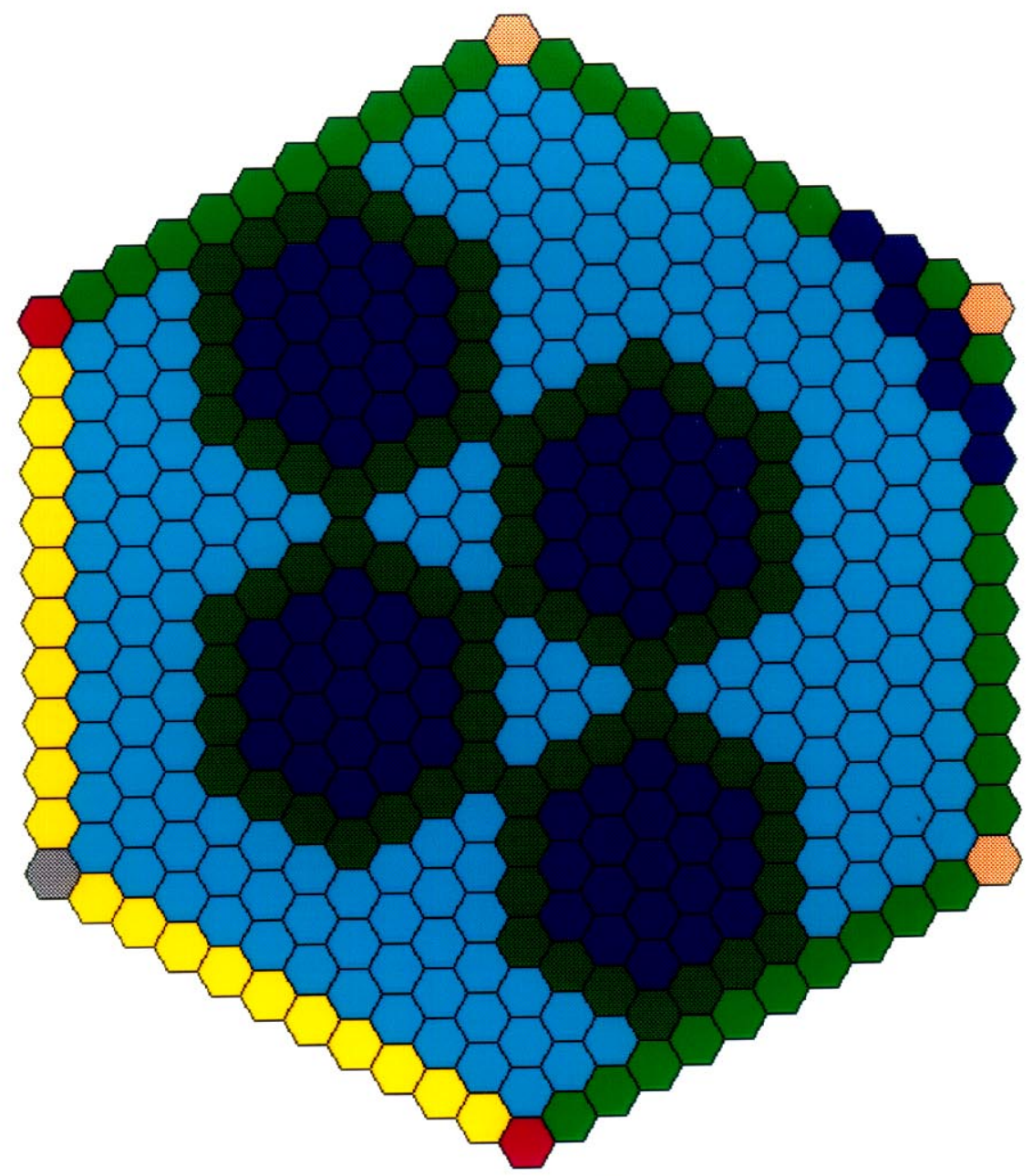

$\begin{array}{ll}\text { Steel } 100 \text { Water } 0 & \text { Steel } 11 \text { Water } 89 \\ \text { Steel } 0 \text { Water } 100 & \text { Steel } 100 \text { Water } 0 \\ \text { Steel } 26 \text { Water } 74 & 50 \text { Water } 50 \\ \text { Steel } 100 & \text { Steel } 50 \text { Water } 50\end{array}$


Comments from ORNL staff on the report, Design Studies of "Island" Type MOX Lead Test Assembly

1. Page 15. For the fifth row in the table, "2-D power peaking factor in assembly," second column, the word "exploitation" is assumed to mean "burnup."

2. Page 20. Currently the "island" option is not being pursued by the Fissile Materials Disposition Program. If, in the future, further studies are performed, depletion (burnup) calculations in US studies would be performed with a computational model in which the LTA is surrounded by uranium assemblies. Such a model will yield burnup-dependent data that is different (maybe not significantly) from a single-MOX-bundle model. However, Styrine reports that TVS-M models (infinite lattice of MOX LTAs) as reported in this report are properly adapted for BIPR calculations. Constants used in BIPR are supposed to be calculated with an asymptotic spectrum of an infinite grid. In RF studies, RF staff find an acceptable (from the point of view of power peaking values in core) plutonium grading in an infinite lattice of MOX LTAs. The parametric calculations reported here approach as close as possible to real situations in core management with BIPR. Plutonium grading is the only "initial data" that is passed to BIPR. Constants for BIPR are prepared by TVS-M for an infinite grid of fuel assemblies with the defined grading.

3. Page 21 and Table 2.9. It is noted that the burnable poison rods (BPR) in the uranium assembly are removed from the assembly after one cycle of irradiation, as is the case for U.S. reactors. While Table 2.9 shows only Ko evolution during irradiation for TVS-M calculation, really, of course, irradiation values more than $\sim 16 \mathrm{MWd} / \mathrm{kg}$ for FA with Boron BPRs will not be reached.

4. Page 22 and Figures 2.41-2.43. The ratio $F_{1} / F_{2}$ and $F_{1}$ are spectral indices but the definitions of these indices are not provided. Styrine reports that F1 and F2 are, correspondingly, fast and thermal fluxes. Lazarenko reports that F1 is a neutron flux (in relative units) for the energy region from $0.625 \mathrm{eV}$ to $10.5 \mathrm{MeV}$. It demonstrates the spatial distribution of fast and slowing down neutrons in assembly with the "island" configuration. The energy boundary between F1 and F2 is $0.625 \mathrm{eV}$. F2 is a thermal neutron flux for the energy region 0 . to $0.625 \mathrm{eV}$. F1 and F2 have obtained from 48-group calculation by condensing procedure (F1-from 1-24 groups, F2-from 24-48 groups).

5. This report is the deliverable for FY 1999 Annual Operating Plan Task 10.2.2.1, milestone d. This milestone also had the internal ORNL designation of 99-1. 

ORNL/SUB/99-B99398V-3

\section{INTERNAL DISTRIBUTION}

$\begin{aligned} \text { 1. } & \text { R. J. Belles } \\ 2-6 . & \text { B. B. Bevard } \\ 7 . & \text { J. J. Carbajo } \\ 8 . & \text { M. D. DeHart } \\ 9 . & \text { F. C. Difilippo } \\ \text { 10. } & \text { R. J. Ellis } \\ \text { 11. } & \text { S. E. Fisher } \\ \text { 12-16. } & \text { J. C. Gehin } \\ \text { 17. } & \text { S. R. Greene } \\ \text { 18. } & \text { R. F. Holdaway } \\ \text { 19. } & \text { D. T. Ingersoll } \\ 20 . & \text { M. A. Kuliasha }\end{aligned}$

21. S. B. Ludwig

22. G. E. Michaels

23. D. L. Moses

24. L. J. Ott

25-29. R. T. Primm III

30. W. J. Reich

31. C. C. Southmayd

32. D. J. Spellman

33. G. L. Yoder, Jr.

34. Central Research Library

35-36. ORNL Laboratory Records (OSTI)

37. ORNL Laboratory Records-RC

\section{EXTERNAL DISTRIBUTION}

38. N. Abdurrahman, College of Engineering, Dept. of Mechanical Engineering, University of Texas, Austin, TX 78712

39. M. L. Adams, Department of Nuclear Engineering, Texas A\&M University, Zachry 129, College Station, TX 77843

40. D. Alberstein, Los Alamos National Laboratory, MS-E502, P.O. Box 1663, Los Alamos, NM 87545

41. J. Baker, Office of Fissile Materials Disposition, U.S. Department of Energy, MD-3, 1000 Independence Avenue SW, Washington, DC 20585

42. L. Holgate, Office of Fissile Materials Disposition, U.S. Department of Energy, MD-1/2, 1000 Independence Avenue SW, Washington, DC 20585

43. N. Fletcher, Office of Fissile Materials Disposition, U.S. Department of Energy, MD-3, 1000 Independence Avenue SW, Washington, DC 20585

44. K. Chidester, Los Alamos National Laboratory, MS-E502, P.O. Box 1663, Los Alamos, NM 87545

45. W. Danker, U.S. Department of Energy, MD-3, 1000 Independence Avenue SW, Washington, DC 20585

46. T. Gould, Lawrence Livermore National Laboratory, P.O. Box 808, MS-L186, Livermore, CA 94551

47. L. Jardine, Lawrence Livermore National Laboratory, P.O. Box 808, MS-L166, Livermore, CA 94551

48. Dr. Alexander Kalashnikov, Institute of Physics and Power Engineering, 1 Bondarenko Square, Obninsk, Kaluga Region, Russia 249020

49-53. D. E. Klein, Associate Vice Chancellor for Special Engineering Programs, The University of Texas System, 210 West Sixth Street, Austin, TX 78701

54. J. O. Nulton, Office of Fissile Materials Disposition, U.S. Department of Energy, MD-3, 1000 Independence Avenue SW, Washington, DC 20585 
55. Dr. Stephen L. Passman, Sandia National Laboratories, Suite 110, 950 L'Enfant Plaza, S.W., Washington, DC 20024-2123

56-60. Dr. Alexander Pavlovitchev, Russian Research Center "Kurchatov Institute," Institute of Nuclear Reactors, VVER Division, VVER Physics Department, 123182, Kurchatov Square, 1, Moscow, Russia

61. K. L. Peddicord, Associate Vice Chancellor, Texas A\&M University, 120 Zachry, College Station, TX 77843-3133

62. P. T. Rhoads, Office of Fissile Materials Disposition, U.S. Department of Energy, MD-4, 1000 Independence Avenue SW, Washington, DC 20585

63. J. Thompson, Office of Fissile Materials Disposition, U.S. Department of Energy, MD-4, 1000 Independence Avenue SW, Washington, DC 20585

64. Mr. Richard H. Clark, Duke/Cogema/Stone \& Webster, 400 South Tryon Street, WC-32G, P.O. Box 1004, Charlotte, NC 28202

65. Mr. Steve Nesbit, Duke/Cogema/Stone \& Webster, 400 South Tryon Street, WC-32G, P.O. Box 1004, Charlotte, NC 28202

66. Mr. Dave Dziadosz, Innsbruck Technical Center, 5000 Dominion Blvd., Glen Allen, VA 23060

67. M. S. Chatterton, Office of Nuclear Reactor Regulation, MS O10B3, United States Nuclear Regulatory Commission, Washington, D.C. 20555-0001

68. U. Shoop, Office of Nuclear Reactor Regulation, MS O10B3, U.S. Nuclear Regulatory Commission, Washington, DC 20555-0001

69. Nagao Ogawa; Director and General Manager; Plant Engineering Department; Nuclear Power Engineering Corporation; Shuwa-Kamiyacho Building, 2F; 3-13, 4-Chome Toranomon; Minato-Ku, Tokyo 105-0001, Japan 